\title{
ON THE MARINE FREE-LIVING COPEPODS OFF BRAZIL
}

(Received 15/10/62)

\author{
T. K. S. Björnberg
}

\section{INTRODUCTION}

Copepods were best studied in coastal, Boreal, Arctic, Antarctic and deep waters. Those from tropical and subtropical waters have been little studied. Little attention has also been given to the marine copepods of the western tropical and subtropical South Atlantic.

The "Plankton" Expedition collected samples along all the northern coast of Brazil up to the mouth of the Amazon River, but it gave general results concerning chiefly the smaller copepods, as a fine meshed net (Hensen egg net) was used to sample the water (Hensen 1911; Dahl 1894). The "Challenger" (Brady, 1883), the "Terra Nova" (Farran, 1929), the "Albatross" (Wilson, 1950, p. 353-354) Expeditions collected at a few stations off Fortaleza, Salvador, Rio de Janeiro and Trindade Island. The cruises undertaken by the Research Ship "M. Lomonosoff" has surveyed the South Atlantic copepod fauna along the $30^{\circ}$ meridian (Kanaeva, 1960) up to $20^{\circ} \mathrm{S}$. During the "Meteor" Expedition stations were occupied along the coast of Brazil, but usually in offshore waters. Only a few of the numerous copepods families represented in the material collected by this expedition were especially treated (Klevenhusen, 1933; Steuer, 1937). In Brazil the ecological study of coastal and inshore copepods was undertaken by Oliveira $(1945 ; 1947)$ at Rio de Janeiro and by Jakobi (1953-59) in the inshore waters of the States of Paraná and Santa Catarina. Carvalho (1939-1952) made a systematic survey of the copepods occurring in the vicinity of Santos and Paraná.

Publ. n॰ 176 do Inst. Ocean. da USP. 


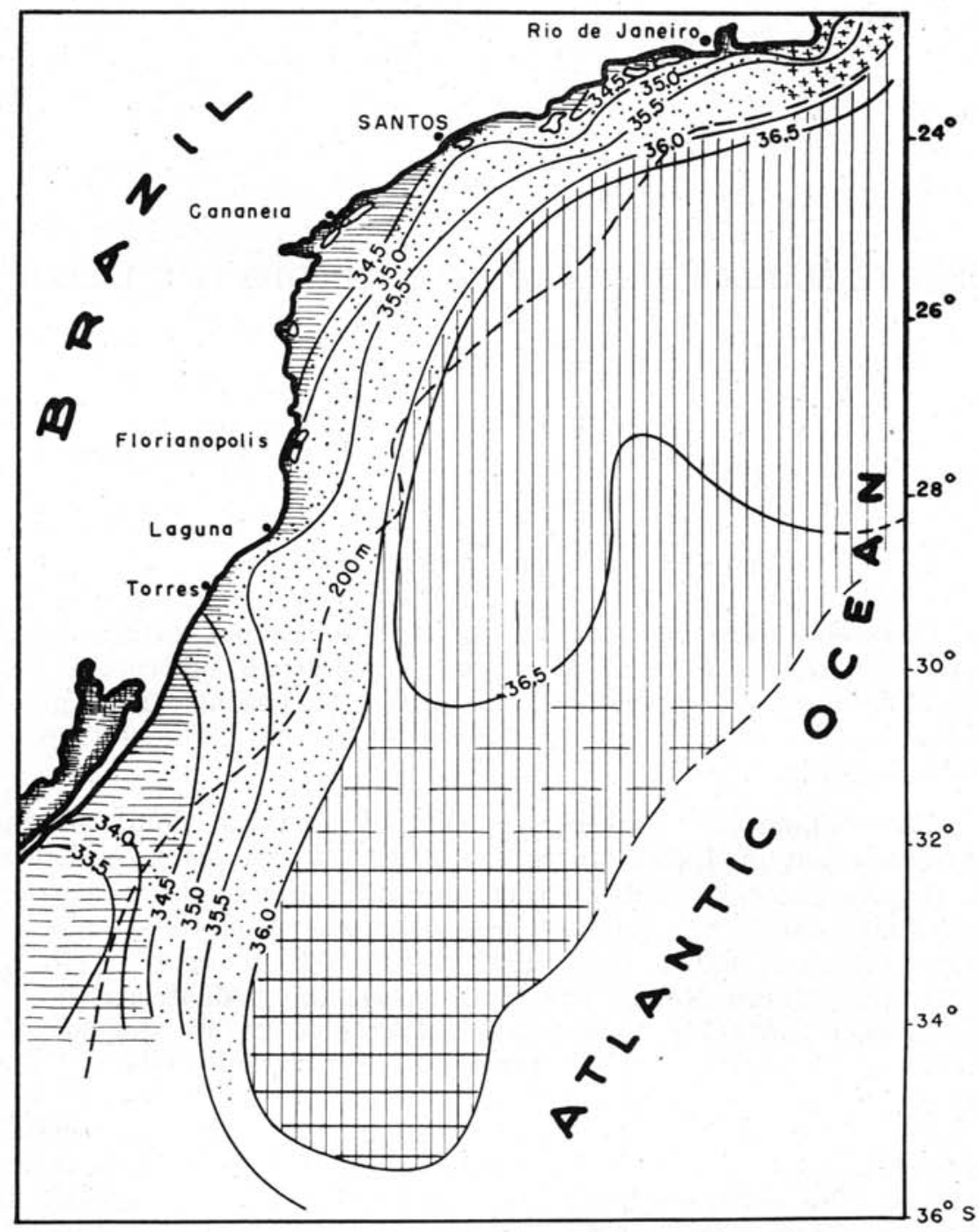

Conventions:

Paracalanus crassirostris Acartia lilljeborghii

Centropages brachiatus

Ctenocalanus vanus

Centropages furcatus

Temora stylifera

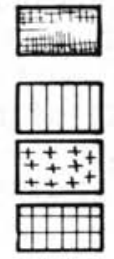

Pseudodiaptomus - Oithona

Corycella gracilis - Nannocalanus minor

Calanus tenuicornis - Ctenocalanus

vanus - Calanoides carinatus

Mecynocera - Corycella rostrala

Map 1 - Typical associations of copepods off the southern coast of Brazil based on map 1 of Emilsson (1961, p. 106). 
Still, in all these studies, coastal and chiefly brackish water have been sparingly sampled. A general survey is here presented, not only of coastal and open-sea waters but principally of shelf waters.

It has been the aim of the Instituto Oceanográfico to study the water masses off the southern coast of Brazil not only hydrographically (Emilsson, 1959-1961) but also biologically (Björnberg \& Forneris, 1956a; 1956b; Vannucci, 1957a; Almeida Prado, 1961). A natural consequence of these studies is the determination of the ecological parameters of each species in the area studied.

In the study of copepods, the depth of the layers sampled has been generally the chief concern of researchers.

Unfortunately few authors have checked the hydrographical conditions of the water layers where the copepods lived at the moment of the catch and failed to consider them. Many copepods considered as coastal by some authors would figure in the species lists as characteristic of higher salinity waters and the "strange" behaviour of some copepods would be considered quite normal, since they belonged to a body of water which carried them to the proximity of the coast when pushed exceptionally near it.

Another point not usually considered is that most ecological and zoogeographical conclusions can only be safely drawn when the number of samples studied come from as wide a range as possible. Thus, what is here found to be true for the waters off Brazil may not be valid for the Pacific Ocean or for Northern Atlantic waters.

After giving a preliminary account of the geographical distribution of pelagic marine copepods (Björnberg, 1959) for the area between $23^{\circ} 58.5^{\prime} \mathrm{S}$ and $34^{\circ} 42.0^{\prime} \mathrm{S}$ off Brazil, more samples taken at widely scattered locations at different months and in different years complete the preliminary list of the epipelagic copepods which may occur in a wider interval off the Brazilian coast. The ecological requirements of some species and their probable horizontal dispersion off Brazil were tentatively established in relation to salinity, temperature, depth of the waters and distance from the coast. From a comparison of these data with those from other seas some parameters concerning the optimum environments of some copepods were determined here for the first time. For this study preference was given to the data published on collections which covered the largest areas. 
MATERIAL AND METHODS

Plankton samples were taken either superficially or vertically from different depths (see lists) to the surface, between $4^{\circ} 57^{\prime} \mathrm{N}$ and $34^{\circ} 42^{\prime} \mathrm{S}$ off the coast of Brazil.

These plankton samples belong to the collections of the Instituto Oceanográgico. Some were donated by foreign institutions like the Japanese Government (samples from the "Toko Maru" cruise) and the Woods Hole Oceanographic Institution ("Atlantis" cruise $\mathrm{n}^{\circ} 247$ along the $36^{\circ} \mathrm{S}$ lat.). Some were donated to the Instituto by the Brazilian Navy. The others were collected by the Institute's staff for several purposes (hydrographical, biological and fisheries research).

Of a much greater number studied only 102 samples are listed in Tables I, III, V, VII, VIII, IX, XI, XIII, XV, because of their value for comparative purposes. Some were chosen because of the homogeneity of their temperature and salinity or because of the localization of the water layers sampled or because special water layers were sampled along with others. In the samples where the fauna or different water layers of different salinity and temperature was mixed, the characteristic copepods of a certain water layer were determined by exclusion from the comparison with samples where only one kind of water was sampled.

So as to be sure that all copepods large and small were observed in the various waters, when possible, samples were chosen which had been caught both by zooplankton and by phytoplankton nets in the same water. It is a known fact that the number of Oncaea, Microsetella, Corycaeus and Oithona present in the sample can be strongly influenced by the type of net used (Hensen 1911, p. 8-20; Almeida Prado, 1962). The larger Euchaeta, Eucalanus, Haloptilus, Neocalanus and Pleuromamma escape the fine meshed nets (Hensen 1911, p. 318; Steuer 1933, p. 102) by active swimming.

A cruise which takes about a month to collect samples may fish only inside a very large patch of a temporary association of species, which will then be misleadingly considered as characteristic for that region (Vannucci 1957b, p. 218). To avoid this wrong interpretation of data, samples of quite different dates and expeditions were selected in which only salinity, temperature and depth of haul were the same. All the copepods of 52 samples with similar parameters were counted and the volume of some of the most common species calculated by the settling method. Of 50 samples, only sub-samples taken with the 5 cc Stempel- 
pipette were counted. The percentage of each species in the sample was calculated. Some samples, taken by horizontal hauls without flowmeter, were only used qualitatively.

The samples in which the same association of species occurred together were grouped and the groups of samples with the greatest distributional affinity were then segregated and regarded as belonging to distinct communities.

The salinity, temperature, depth and distance from the shore of the groups of samples were then analysed to establish some of the characteristic features of the environment where the community occurred. This method has been used before in biocoenology (Macfadyan 1957, p. 223).

For the most common species graphs were drawn which indicate the probability of finding each species in each of the different environments studied. Five environments were represented in each graph by a column each. The one representing "Tropical Waters" is labelled $T$ (above $36.00 \%$ salinity and above $20^{\circ} \mathrm{C}$ temperature); SST stands for "Surface Subtropical Waters" (salinity around $36 \%$ and temperature of $18^{\circ} \mathrm{C}$ or less); DST for "Deeper Shelf Waters" (salinity between $34 \%$ and $36 \%$, temperature under $20^{\circ} \mathrm{C}$ ); SS for "Surface Shelf Waters" (same salinity and temperature above $20^{\circ} \mathrm{C}$ ); $C$ for coastal waters with low salinity and variable temperature. In each column no shading means no probability of finding the species in the samples from this environment; horizontal shading indicates the probability of finding the species in percentages less than one in samples from this environment; cross shading indicates the probability of finding it in percentages higher than one and black shading represents the probability of finding it in the largest percentages of the total number of copepods. For example: in Figure 1, in tropical waters there is no probability at all of finding Calanus tenuicornis; in surface subtropical waters there is a probability of finding it in half of the samples examined from this environment, as it was present in one sample in percentage above one and in four samples in percentages under one, in a total of 11 samples from the represented environment. Thus, of this total $(=1)$, a quantity of 0.1 of the column is horizontally striped, another of 0.4 is crossstriped and the rest is not shaded. For greater drawing facilities the numbers were approximated to the first decimal. In Figure 19 black shading shows that Ctenocalanus vanus has a probability of being found in dominant percentages of the total number of copepods in 0.3 of the total number of samples examined from deeper shelf waters off the Brazilian coast. 
The expression "tropical waters", "surface shelf waters", "deeper shelf waters", etc., were chosen in order to avoid the use of the expression "water mass", because the associations studied in this paper clearly indicate the existence of several environments in the same water mass. The nomenclature used delimitates the environments better and was therefore preferred.

Warm water is here considered as that which shows temperature above $23^{\circ} \mathrm{C}$. Cool water is considered that with $22^{\circ} \mathrm{C}$ to $18^{\circ} \mathrm{C}$. Cold water is considered water with less than $18^{\circ} \mathrm{C}$. High salinity is here considered as salinity above $36 \%$. Medium salinity are salinities between 34 and $36 \%$. Low salinity is the salinity under $34 \%$ and brackish water that with salinity below $32 \%$. The expression "eurythermic cryophile" is applied in this paper to species which are usually found in the lower temperatures (around $18^{\circ} \mathrm{C}$ or less) of the waters off the Brazilian coast.

All the copepods caught were fixed in $4 \%$ formalin and were measured in millimeters in dorsal or in lateral view from the anterior extremity of the cephalon to the end of the furca, as indicated under the heading size for each species. So as not to prolong this paper unnecessarily no list of synonyms was usually given for each species. Descriptions of nearly all species mentioned are found in Giesbrecht (1892) and in Rose (1933) which were mostly used for identification. In a few cases synonyms not mentioned before by other authors were exceptionally referred to.

The numbers which follow the sample numbers under the heading OCCURRENCE refer to the absolute number of specimens of the species found in the sample. When the total number of animals was calculated from the number of specimens present in a sub-sample an asterisk $(*)$ follows the number in question. The "Pr." standing after the sample number means "present in the sample".

The total quantity of plankton was measured by the settling method and the volume of plankton and of the copepods per cubic meter of water was computed from the data on the total volume of water filtered through the plankton nets used. The different nets used are indicated in the Station lists and the type of haul is also indicated there. 


\section{LIST OF SPECIES}

\section{Calanoida}

Calanus tenuicornis Dana Nannocalanus minor (Claus) Calanoides carinatus (Kröyer) Neocalanus gracilis (Dana) Neocalanus robustior (Giesbr.) Undinula vulgaris (Dana)

Eucalanus attenuatus (Dana)

Eucalanus monachus (Giesbr.)

Eucalanus subcrassus (Giesbr.)

Eucalanus pileatus Giesbr.

Eucalanus elongatus (Dana)

Eucalanus subtenuis (Giesbr.)

*Rhincalanus nasutus (Giesbr.)

Rhincalanus cornutus (Dana)

Mecynocera clausi Thompson

Paracalanus aculeatus Giesbr.

Paracalanus parvus Claus

Paracalanus crassirostris Dahl

Acrocalanus longicornis Giesbr.

Acrocalanus gracilis Giesbr.

*Calocalanus pavo Dana

*Calocalanus styliremis Giesbr.

*Calocalanus plumulosus $(=C$. tenuis Farran)

Clausocalanus arcuicornis Dana

Clausocalanus furcatus (Brady)

Ctenocalanus vanus Giesbr.

*Aetidiid sp. 1

* Aetidiid sp. 2

* Euaetideus giesbrechti Cleve

Undeuchaeta major Giesbr.

Candacia simplex Giesbr.

Candacia pachydactyla (Dana)

Candacia bispinosa (Claus)

Candacia bipinnata (Giesbr.)

Candacia curta (Dana)

Candacia aethiopica (Dana)

* Euchirella rostrata (Claus)

* Euchirella brevis Sars

Euchaeta marina (Prestand.)

* Euchaeta acuta (Giesbr.)
Scolecithrix danae (Lubb.)

* Scolecithricella dentata (Giesbr.)

*Lophothrix latipes (T. Scott)

"Scaphocalanus curtus (Farran)

Centropages furcatus (Dana)

Centropages violaceus (Claus)

*Centropages brachiatus (Dana)

Pleuromamma abdominalis (Lubb.)

Pleuromamma gracilis (Claus)

Pleuromamma xiphias (Giesbr.)

Pleuromamma borealis F. Dahl

Temora stylifera Dana

* Temeropia mayumbaensis T. Scott

Lucicutia flavicornis (Claus)

* Lucicutia ovalis Wolfencen

*Lucicutia clausi (Giesbr.)

${ }^{*}$ Heterorhabdus spinifrons (Claus)

Heterorhabdus papilliger (Claus)

Haloptilus acutifrons (Giesbr.)

Haloptilus spiniceps (Giesbr.)

Haloptilus fertilis (Giesbr.)

Haloptilus longicornis (Claus)

Euaugaptilus hecticus Giesbr.

Pseudodiaptomus acutus (F. Dahl)

$P$ seudodiaptomus richardi

(F. Dahl)

Pontellopsis brevis (Giesbr.)

Pontellopsis villosa Brady

Pontellopsis perspicax (Dana)

Pontellina plumata Dana

Labidocera fluviatilis F. Dahl

Labidocera acutifrons (Dana)

Calanopia americana F. Dahl

Acartia lilljeborghii Giesbr.

Acartia danae Giesbrecht

Acartia negligens Dana

* Acartia longiremis Lilljeborgh

Acartia clausi Giesbrecht

Acartia tonsa var. cryophylla var. $\mathrm{n}$.

Acartia giesbrechti F. Dahl

\section{Harpacticoida}

Clytemnestra scutellata Dana

Euterpina acutifrons (Dana)

Macrosetella gracilis (Dana)

Oculosetella gracilis Sars

Microsetella rosea Dana
Microsetella norvegica (Boeck)? Miracia efferata Dana

Parathalestris sp.

Longipedia mourei Jakobi 


\section{Cyclopoida}

Oithona robusta Giesbr.

* Oithona similis Claus

Oithona plumifera Baird

Oithona ovalis Herbst

Oithona setigera Dana

Oithona nana Giesbr.

* Oithona oculata Farran

Oncaea venusta Philippi

Oncaea media Giesbr.

* Oncaea conifera Giesbr.

* Oncaea mediterranea Claus?

Oncaea minuta Giesbr.

Oncaea venusta var. venella Farran

*Oncaea subtilis Giesbr.

Lubbockia squillimana Claus

Corycaeus speciosus Dana

Corycaeus amazonicus F. Dahl

Corycaeus limbatus Brady

Corycaeus flaccus Giesbr.

Corycaeus furcifer Claus

Corycaeus lautus Dana

Corycaeus giesbrechti F. Dahl
Corycaeus ovalis Claus

Corycaeus latus Dana

Corycaeus crassiusculus Dana

Corycaeus typicus Kröyer

Corycaeus africanus Dahl

Corycella rostrata Claus

Corycella gracilis Dana

Sapphirina angusta Dana

Sapphirina auronitens-sinuicauda Brady

Sapphirina opalina-darwini Dana

* Sapphirina metallina Dana

*Sapphirina stellata Giesbr.

* Sapphirina maculosa Giesbr.

Sapphirina nigromaculata-scarlata Claus

Sapphirina intestinata Giesbr.

Sapphirella tropica Wolfenden

Copilia vitrea (Haeckel)

Copilia mirabilis Dana

Copilia mediterranea (Claus)

Copilia quadrata Dana

Copilia lata Giesbr.

\section{SYSTEMATIC NOTES AND DISTRIBUTION OF THE INDIVIDUAL SPECIES}

Fam. Calanidae

Calanus tenuicornis Dana

(Fig. 1)

SIZE $-\sigma^{*} 1.85 \mathrm{~mm}-1.6 \mathrm{~mm}$; ㅇ $2.0 \mathrm{~mm}$.

OCCURRENCE - M 409 (1), M 395 (1), M 163 (9), M 162 (9),

M 161 (1), M 160 (Pr.), M 78 (3), M 76 (45), M 75 (51), M 74 (12), M 73 (32).

ECOLOGY - This species appeared only sparingly in the samples belonging to southern waters off Brazil with larger frequency in surface subtropical and in greater numbers in deeper shelf waters (Fig. 1). It also appeared sparingly south of the Cape Colony on the eastern part of the Atlantic (Table XVI). Kusmorskaya (1959) considers it as one of the most abundant

* New records 
copepods in Autumn in the transition zone between boreal and southern warm water species in the North Atlantic. The temperature of the transition zone ranges between $16^{\circ}$ and $12^{\circ} \mathrm{C}$ and salinities between 36.00 and $35.5 \%$, which are approximately the hydrographical characteristics of the waters where $C$. tenuicornis occurred, off the Brazilian coast. Farran (1926, p. 228) and Heinrich (1961, p. 38, tab. 1) pointed out that the animal occurs usually in greater numbers between 100 and $200 \mathrm{~m}$ depth in the subtropical region of the North Atlantic and Pacific. Vervoort (1957) did not register this animal in Antarctic waters but he found it in samples taken from 250 to $100 \mathrm{~m}$ depth in the tropical region by the "Snellius" Expedition (Vervoort 1946, p. 22).

Tables X and VIII show that C. tenuicornis is characteristic of subtropical waters in all the oceans. It can be classified as an eurythermic cryophile preferring the lower end of the temperature range for warm waters.

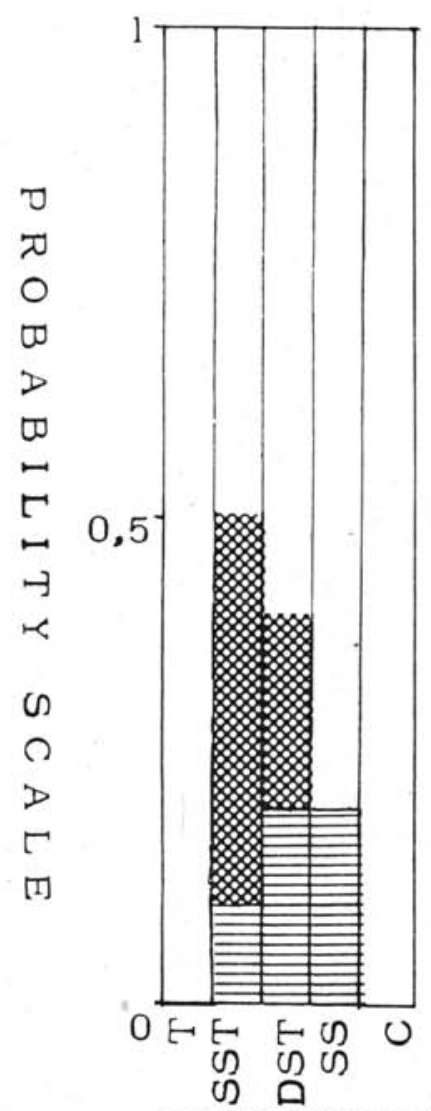

ENVIRONMENTS

Fig. 1 - Probability of occurrence of Calanus tenuicornis in different environments.

\section{Nannocalanus minor (Claus)}

(Fig. 2)

Size $-\sigma^{\star} 1.4 \mathrm{~mm}$ to $1.8 \mathrm{~mm}$; 1.8 to $1.9 \mathrm{~mm}$. Present in two different forms, a smaller and stouter one and a longer and more transparent one; only copepodites of the latter were found.

OCCURRENCE - M 513 (3), M 510 (8), M 497 (1), M 489 (2880)*, M 451 (20), M 409 (15), M 407 (71), M 403 (123), M $402(240)^{*}$, M $400(17)$, M $395(115)$, M $394(640)^{*}$, M 389 (Pr.), M 368 (3), M 364 (200)*, M 363 (11), M 315 (61), M 314 (55), M 247 (209), M 246 (73), M 245 (5), M 244 (178), M 243 
(12), M 242 (33), M 241 (33), M 240 (36), M 232 (120)*, M 208 (1), M 189 (8), M 187 (Pr.), M 186 (34), M 166 (69), M 164 (2), M 163 (4), M 162 (12), M 161 (206), M 160 (25), M 114 (31), M 113 (3), M 112 (6), M 111 (5), M 100 (4), M 99 (18), M 98 (5), M 97 (Pr.), M 96 (15), M 95 (15), M 93 (1), M 89 (1), M 88 (6), M 78 (2), M 76 (7), M 75 (52), M 74 (26), M 39 (3), M $38(20)^{*}$, M 37 (41), M 36 (29), M 35 (15), M 33 (58), M 32 (4), M 30 (Pr.), P 10 (1), E 164 (2).

ECOLOGY - It was one of the most common of the euryhaline and eurythermic copepods. Abundant in waters with salinity higher than $35.00 \%$ and temperature above $21^{\circ} \mathrm{C}$ and present

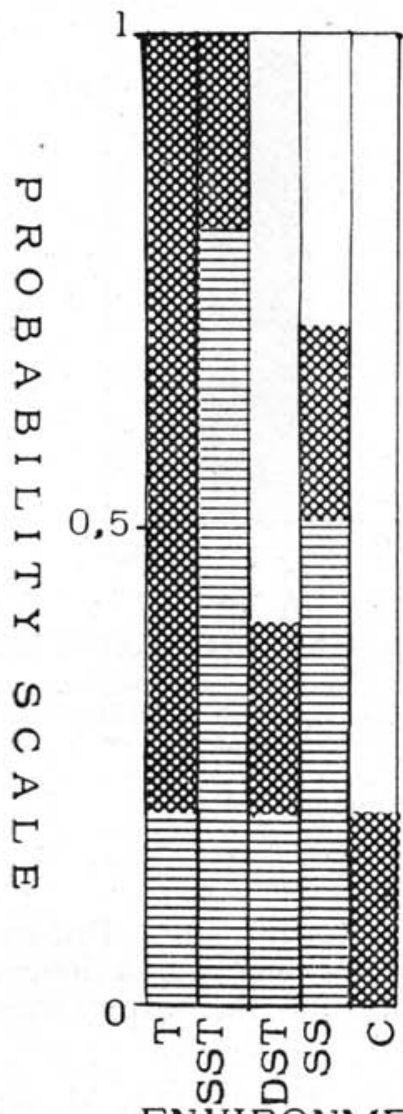

EN VIRONMENTS

Fig. 2 - Probability of occurrence of Nannocalanus minor in different environments. in small numbers in the colder coastal waters $\left(20^{\circ} \mathrm{C}\right.$ or between 15.40 and $14.38^{\circ} \mathrm{C}$ ) off the south of Brazil. It was found off the Brazilian coast in the Brazil Current, in the South Equatorial Current, in higher percentages in tropical and in surface subtropical waters (Fig. 2) and in surface shelf waters (Table VIII and XIII). In deeper shelf waters it did not occur or only occurred sparingly, thus indicating its preference for the surface layers. The histogram (Fig. 2) indicates that it may occur in colder waters of lower salinities. Deevey (1952a, p. 110) considers it as an indicator of offshore waters of high salinities in North American Atlantic waters. Bainbridge (1960, tab. 1, p. 932-933) registered it in the Guinea Gulf between temperatures 27.8 and $22.1^{\circ} \mathrm{C}$. It occurs off the African Atlantic coast at Angola (Marques 1958, p. 205) where temperatures range from 30 to $14^{\circ} \mathrm{C}$ in the upper $50 \mathrm{~m}$ being usually under $20^{\circ} \mathrm{C}$, and the salinities are usually around $35.5 \%$ (Vilela 1953, tab. 4-5). In the Pacific, Wilson (1950, p. 268 ) recorded the presence of this 
species in Philippine waters with much lower salinities than in Atlantic oceanic waters but unfortunately no data were given as to the number of specimens per sample. It was abundant between latitudes 32 and $33^{\circ} \mathrm{S}$ in the middle of the Atlantic and off South Africa in subtropical waters (Table XVI). Farran (1929, p. 215) found its greatest numbers in the tropical Atlantic and next, off New Zealand in subtropical waters. Vervoort (1946, p. 26) usually records this species in samples from upper layers of tropical waters in the Indo-Pacific equatorial region, but also in samples from deep layers $(1,000-555 \mathrm{~m})$. According to Brodsky (1959, p. 146) it is characteristic of the subtropical epipelagial of both hemispheres. Heinrich (1961, p. 83) observed a diurnal migration down to $200 \mathrm{~m}$ depth in the western subtropical Pacific.

\section{Neocalanus gracilis (Dana)}

(Figs. 3, 4, 5)

SIzE - -2.5 to $3.5 \mathrm{~mm}$. Vervoort (1946, p. 41) registered sizes from 2.43 to $3.5 \mathrm{~mm}$ in the "Snellius" Expedition material. The specimens studied here are among the largest recorded till now. Oliveira (1947, p. 457) registered sizes of $3.5 \mathrm{~mm}$ also.

OCCURRENCE - M 513 (120)*, M 510 (20)*, M 407 (7), M 403 (12), M 402 (Pr.), M 400 (5), M 395 (40), M 364 (320)*, M 315 (23), M 314 (5), M 247 (76), M 246 (8), M 245 (16), M 244 (46), M 243 (13), M 242 (23), M 241 (4), M 240 (33), M 232 (40), M 223 (Pr.), M 166 (11), M 161 (7), M 114 (2).

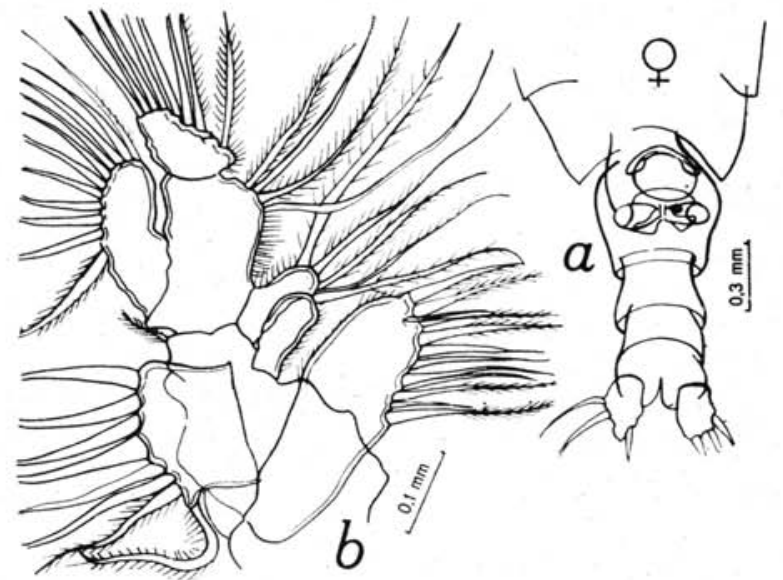

Fig. 3 - Neocalanus gracilis: a - thorax and abdomen of adult female, ventral view; b - first maxilla. 


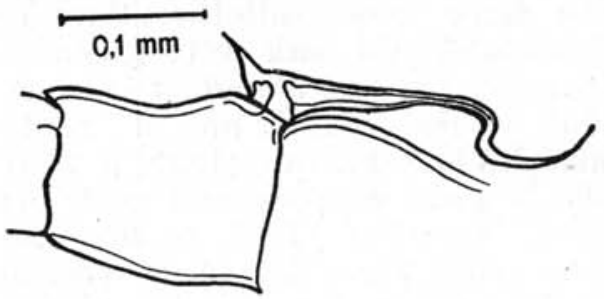

Fig. 4 - Neocalanus gracilis: Double hook on the second basal joint of the first pair of legs.

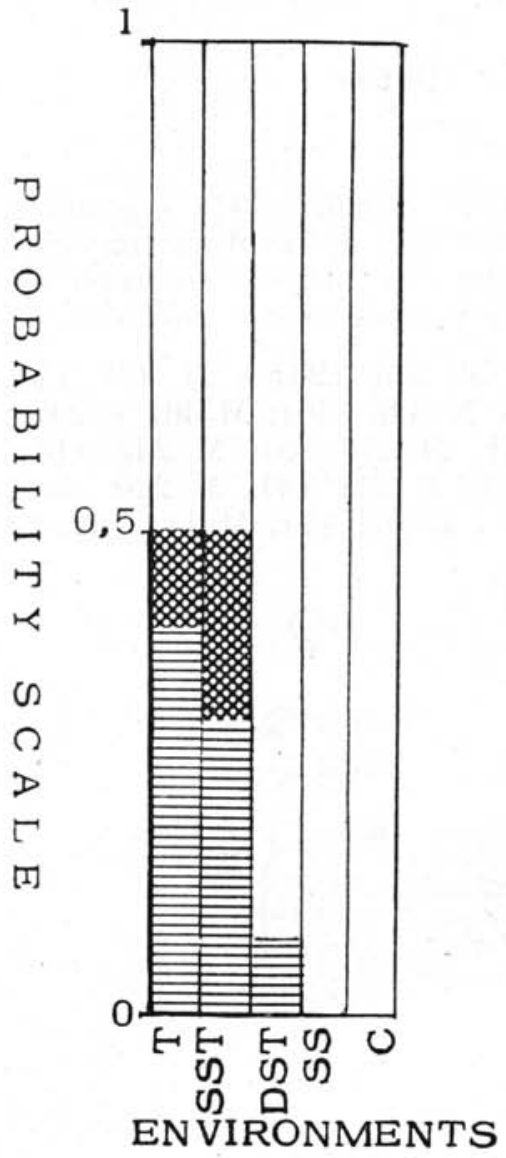

Fig. 5 - Probability of occurrence of Neocalanus gracilis in different environments.
Systematic NOTES Unusually large specimens were at first mistaken for Megacalanus copepodites (Björnberg 1959, p. 138). The size and the pronounced genital swelling of the genital segment of the female specimens here studied might also lead to a confusion with $N$. robustior. The anatomy of the adult specimens, the abdomen (Fig. 3-a) and the maxilla leave no doubt, however, as to their correct identity. The distinct double hook on the second basal joint of the first pair of legs (Fig. 4) is already present in the young copepodites. The first antenna (5 $\mathrm{mm}$ long in the $3 \mathrm{~mm}$ long male) reaches far beyond the furca in both sexes, by 6 joints in the male. In the $3 \mathrm{~mm}$ long male of $N$. robustior the antenna is short (3 $\mathrm{mm}$ long) and reaches only up to the furca. The hook on the second basal segment of the first pair of legs differs from that of $N$. robustior.

ECOLOGY - It was found quite frequently in catches made in very saline water layers $(35.90 \%$ or more) in the surface tropical and subtropical (Fig. 5) waters. It usually was caught in the upper layers during the night or in the early morning. Catches made during the day were poor in number of specimens, strongly indicating migration of the species to deeper waters during the day. Vervoort (1946, p. 43) states that there are no signs of a diurnal migration of this species, but both this author 
and Farran (1926, p. 230) recorded a greater abundance of this species from about $50 \mathrm{~m}$ or more to $250 \mathrm{~m}$ depth approximately in tropical and subtropical waters. Vervoort (1957, p. 31) registered N. gracilis in Antarctic waters at depths between $250 \mathrm{~m}$ and $750 \mathrm{~m}$ in salinities between 34.50 and $35.00 \%$ and temperatures of 1.79 to $11.73^{\circ} \mathrm{C}$. The animal may be more frequent at $130 \mathrm{~m}$ depth (Moore 1949, p. 42-43) in the North Atlantic off the Bermudas. It was present in samples of subtropical waters in the middle South Atlantic. Heinrich $(1960$, p. 36) registered the animal in greater numbers between $0^{\circ}$ and $25^{\circ}$ Lat. $\mathrm{N}$ in the Western Pacific where the salinity according to Burkov (1960, p. 117 , tab. 7) ranges from 34.2 to $35.0 \%$ and temperatures from 26 to $20^{\circ} \mathrm{C}$.

$N$. gracilis as well as $N$. minor are the two characteristic copepods of the subtropical oceanic epipelagial in both hemispheres according to Brodsky (1959, p. 146). Kusmorskaya (1959) considers them as partially subtropical and points out that Calanus helgolandicus and Neocalanus gracilis have the same distribution in the transition zone between boreal and southern warm water species during Spring.

\section{Neocalanus robustior (Giesbr.)}

SIZE $-\sigma^{*} 3.1 \mathrm{~mm}$.

OCCURRENCE - M 244 (1), M 240 (2), M 78 (1).

REMARKS $-N$. robustior was present in very small numbers in three samples. It is here recorded for the first time in Brazilian waters. Marques (1958, p. 205) registered it in African Atlantic waters. It is a moderately deep water species according to Vervoort (1946, p. 46) and few specimens were captured here as nearly all our samples were taken in the upper $150 \mathrm{~m}$. It appeared only in samples of high salinity, but the few data do not permit further considerations.

\section{Undinula vulgaris (Dana)}

(Figs. 6-7)

Size - o $2.0 \mathrm{~mm}$; ㅇ $2.5 \mathrm{~mm}$.

OCCURRENCE - M 510 (12), M 497 (25), M 489 (1380)*, M 451 (60), M 409 (Pr.), M 407 (16), M 403 (8), M 402 (200)*', M $394(280)^{*}$, M 368 (4), M 365 (Pr.), M 364 (8), M 363 (1), M 357 (Pr.), M 315 (100), M 314 (27), M 283 (1), M 247 (56), M 246 (42), M 245 (22), M 244 (55), M 243 (27 juv.), M 242 (19), M 241 (108), M 240 (40), M 232 (80), M 189 (1), M 114 
(2), M 99 (26), M 98 (56), M 97 (30), M 96 (3), M 95 (8), M 78 (34), M 75 (3), M 39 (3), M 38 (5), M 37 (4), M 36 (2), M 35 (15), M 33 (6), M 30 (1).

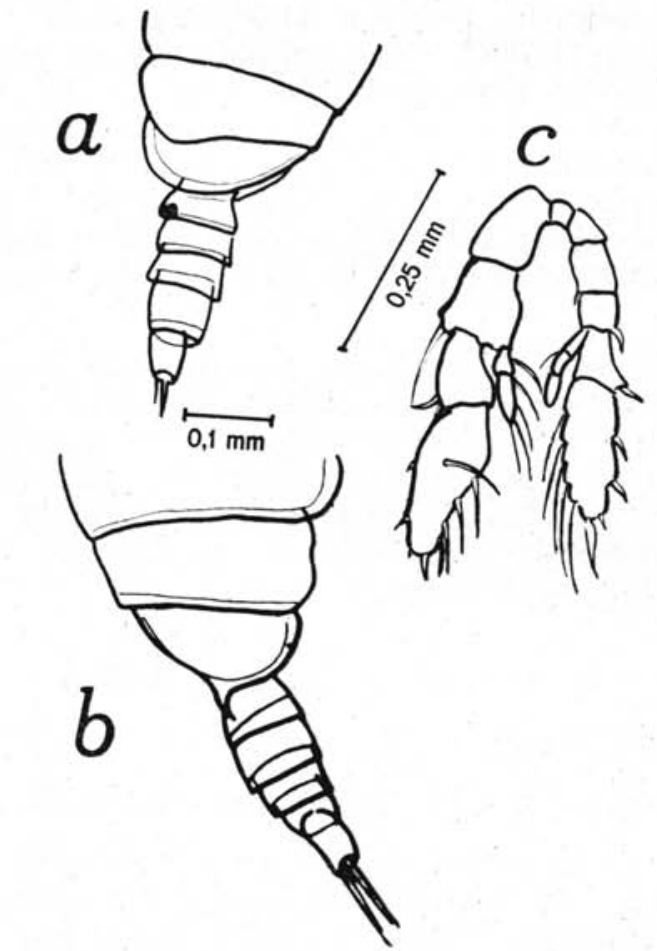

Fig. 6 - Undinula vulgaris: a - Thorax and abdomen of young specimen in profile; b - the same in adult female specimen; c fifth legs of last copepodite of male specimen.

Systematic NOTEs - The female specimens which occur in Brazilian waters have two hooklike spines on the last thoracic segment (Fig. 6-b) as in U. vulgaris forma typica Sewell (Vervoort 1946, p. 73). In the young specimens the segment is rounded off and presents no spines (Fig. 6-a). The fifth legs of the male's last copepodite also have been figured (Fig. 6-c).

ECOLOGY - One of the most numerous copepods in waters of high salinity (above $36.00 \%$ o $)$ and high temperature (above $25^{\circ} \mathrm{C}$ ) in our samples (Fig. 7). The number of specimens of this species was smaller in waters of high salinity and lower temperatures at the surface and disappeared in the samples taken from deep waters with temperatures lower than approximately 
$20^{\circ} \mathrm{C}$. It appears in surface waters of approximately 35.00 to $36.00 \%$ salinity and temperature between 18 and $22^{\circ} \mathrm{C}$. It is absent or rare in samples from deep layers. In the Indo-Pacific (Vervoort 1946, p. 74-75) it occurred in maximum numbers at the surface in temperatures around $28^{\circ} \mathrm{C}$ and salinities around $34.00 \%$. Farran (1936, p. 75) classified it as "coastal"; other" authors, as "oceanic" (Yamazi 1958 , p. 417). It had already been recorded from the South West Atlantic (Sewell 1948, p. 450) and off Rio de Janeiro (Vervoort 1946 , p. 76). It is recorded here also in the Middle South Atlantic and off South Africa in waters of temperature and salinity as mentioned above. Although it did not usually occur in large numbers in our shelf waters, the results of the "Great Barrier Reef" Expedition (Farran 1949, p. 296), of Fleminger (1959, p. 154) for the Gulf of Mexico and of Bainbridge (1960, tab. 1) for the Gulf of Guinea show that this copepod prefers shelf waters with an influence of oceanic water.

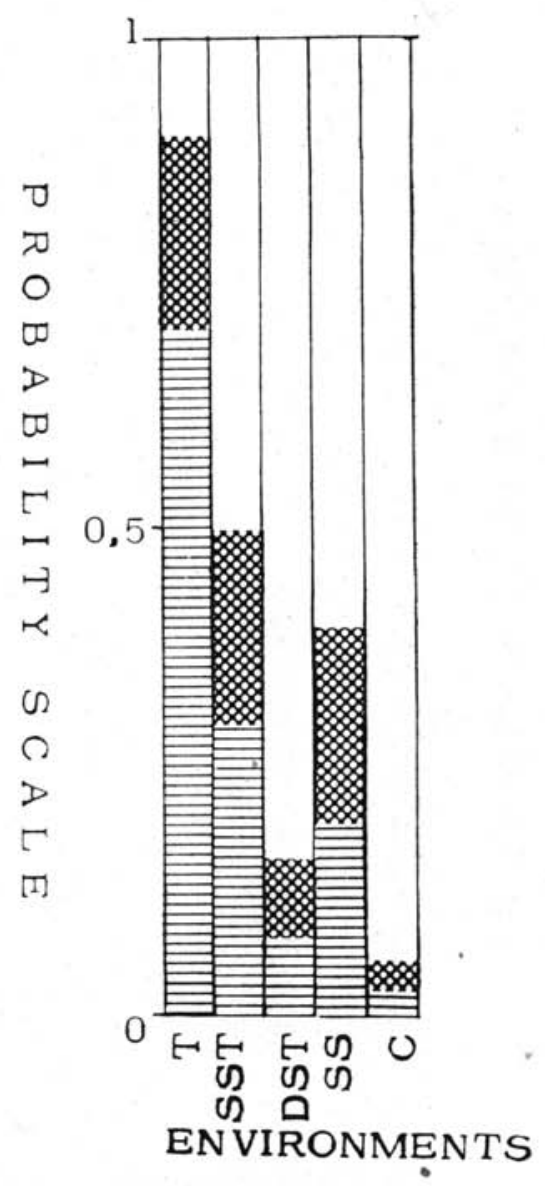

Fig. 7 - Probability of occurrence of Undinula vulgaris in different environments.

\section{Calanoides carinatus (Kröyer)}

(Fig. 8)

SIZE - $1.6-2.5 \mathrm{~mm}$; o $2.5 \mathrm{~mm}$.

OCCURRENCE - M 395 (1), M 389 (Pr.), M 238 (140), M 236 (402), M 100 (3), M 95 (Pr.), M 89 (11), M 88 (109), M 78 (2), M 75 (6), M 38 (7), M 36 (1), M 33 (1), E 5 (1)*, V 19 (360)*, V 2 (Pr.), V 1 (Pr.).

ECology - In two samples it was one of the most numerous copepods in coastal surface waters $\left(14.38-15.40^{\circ} \mathrm{C}\right)$. of low salinity. 


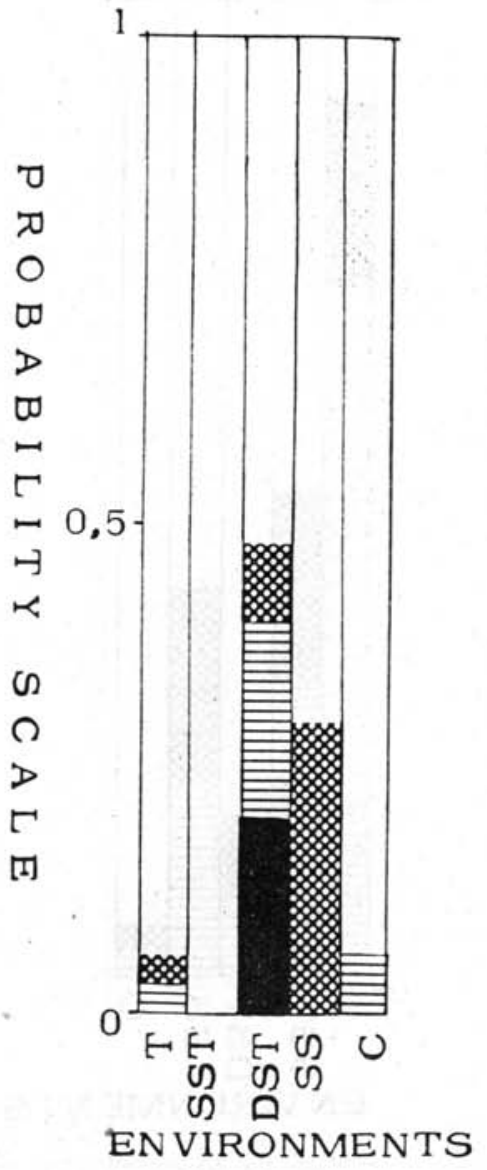

Fig. 8 - Probability of occurrence of Calanoides carinatus in different environments.
In the other samples it was sometimes quite numerous especially in deeper waters ( $\mathrm{V}$ 1, V 19). Farran (1926, p. 229) and Vervoort $(1946$, p. 35$)$ mention it as occurring in deep waters in tropical and subtropical regions and the first considers it as a deep water species in the Bay of Biscay. As our hauls were nearly always on the surface, it was present only in a few samples. All the other samples in which it occurred were of water layers of high salinity $(36.8-35.0 \%$ oo $)$ and temperatures between 22.8 and $16.4^{\circ}$ C. These water layers show the approximate limits of temperature and salinity of the subtropical water mass (Emilsson 1959, p. 46). It was frequently observed in African waters off the Atlantic coast of Angola (Marques 1958 , p. 205) in salinities around $35.5 \%$ and temperatures usually under $20^{\circ} \mathrm{C}$ (Vilela 1953, tab. 4-7). It was exceptionally abundant in African waters on the edge of the shelf in the Gulf of Guinea (Bainbridge 1960, tab. 1) in catches made through layers of water with temperatures under $21^{\circ} \mathrm{C}$ (Bainbridge, personal information). C. carinatus seems to have the same salinity preferences as $N$. minor, but while the latter species seems to prefer superficial layers and appears also in warmer waters, C. carinatus prefers the deeper and cooler layers of the shelf waters in the subtropical region (Fig. 8). Both occur in the cold coastal, surface waters of the south, $N$. minor sparingly and $C$. carinatus as one of the dominant species of copepods. This species is the dominant copepod in the colder waters (around $12^{\circ} \mathrm{C}$ ) of the upper $50 \mathrm{~m}$ of the epipelagial near the southern subtropical convergence line (Vervoort 1957, p. 29). Its occurrence in southern Brazilian cold coastal and deep shelf waters is evidence of the influence of the cold current of the South (Falklands Current). 


\section{Fam. Eucalanidae}

\section{Eucalanus attenuatus (Dana)}

\section{SIZE — $+4.5 \mathrm{~mm}$; $\sigma^{*} 3.0 \mathrm{~mm}$.}

OCCURRENCE - M 403 (1), M 394 (Pr.), M 368 (Pr.), M 364 (Pr.), M 363 (4), M 247 (1), M 240 (2), M 187 (1), M 173 (1), M 113 (1), M 88 (1), M 78 (1).

ECOLOGY - It was usually found in water over great depths in salinities between 35.00 and $36.00 \%$ and temperatures from $27^{\circ} \mathrm{C}$ to $18.2^{\circ} \mathrm{C}$ and also in one sample of very cold and less saline water from the South (M 88).

It always appeared in small numbers excepting in one sample in which it represented $6.2 \%$ of the total number of copepods.

It had been previously recorded off Rio de Janeiro (Farran 1929, p. 218), off Santos and Guaratuba (Carvalho 1944, p. 91; 1952, p. 140) and off the Atlantic coast of Africa. The present data enlarge its distribution considerably.

It is considered by Deevey (1952a, p. 90) as an indicator of the off-shore waters of high salinity from the Gulf Stream. It occurs in the Brazil Current but probably at greater depths for it was captured several times at night or in the early morning, suggesting that its presence in surface layers might be due to vertical migration.

In the colder subtropical waters off South Africa and in the southern mid-Atlantic it is sometimes substituted by E. mucronatus.

In the Pacific open-sea waters off the South American coast, off the Philippines and off Hawaii (Wilson 1950, p. 207-208) it occurred in waters of salinities between 32.00 and $35.5 \%$. It was recorded in the cold waters of the Bering Sea. Farran (1929, p. 218) found large numbers of this copepod in the South Temperate Atlantic. It was frequently the most numerous calanoid copepod between 30 and $60 \mathrm{~m}$ depth in the collection of the "Snellius" Expedition made in the Indo-Pacific (see Vervoort's data 1946 , p. 96-97). It was usually absent in the surface layer and in the deeper layers where it sometimes occurred, but singly. The salinities of the $50 \mathrm{~m}$ deep layers sampled by the "Snellius" showed a temperature average of approximately $25.5^{\circ} \mathrm{C}$ (ranging from 28.7 to $24.54^{\circ} \mathrm{C}$ ) and a salinity average around $34.4 \%$ (ranging from 33.03 to $34.60 \%$ ). Thus, as a true eucalanid, this species prefers the middle and lower salinities in the off-shore waters. This explains its scarcity in the Brazil Current where the salinity is too high. It is strongly eurythermic, but prefers warmer 
waters and thus was not recorded by Heinrich (1961), Vervoort (1957), Furuhashi (1961), Colebrook et al. (1961), Fleury (1950), etc., who studied material from colder waters.

\section{Eucalanus subcrassus Giesbrecht}

(Fig. 9)

\section{SIZE - o $1.7-2.03 \mathrm{~mm}$; ㅇ $2.00-2.25 \mathrm{~mm}$.}

OCCURRENCE - M 510 (20)*, M 451 (1), M 389 (480)*, M 368 (Pr.), M 365 (Pr.), M 283 (70), M 265 (690)*, M 246

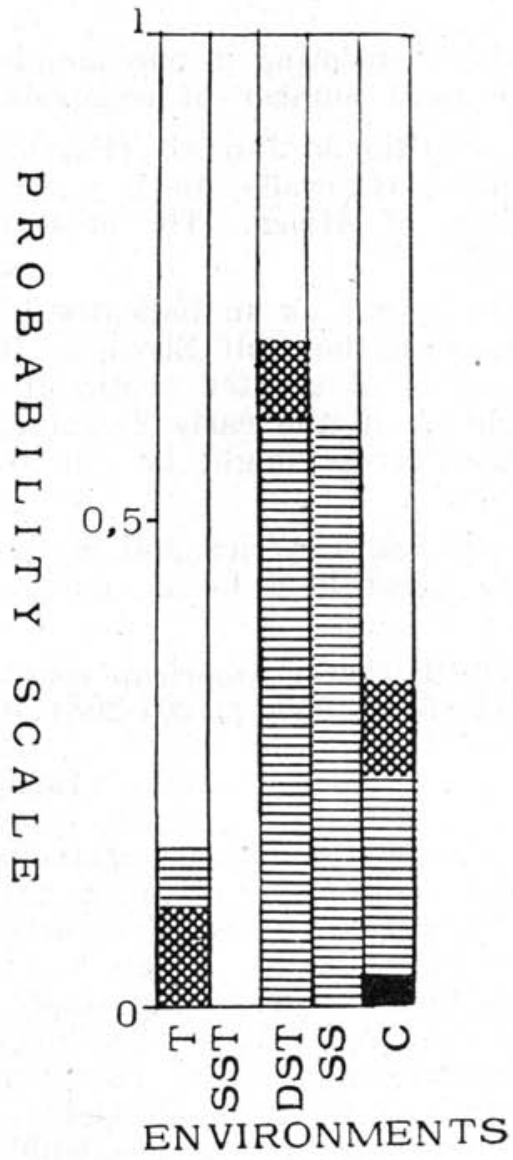

Fig. 9 - Probability of occurrence of Eucalanus subcrassus in different environments.
(1), M 189 (4), M 186 (4), M 173 (14), M 144 (1), M 111 (2), M 107 (Pr.), M 95 (5), M 93 (21), M 89 (3), M 88 (22), M 78 (67), M 76 (57), M 74 (53), M 73 (11), M 39 (140), M 38 (30), M 37 (16), M 36 (28), M 35 (13), M 33 (18), M 32 (50), M 31 (11), M 30 (8), E 164 (Pr.), E 39 (8), E $24(140)^{*}$, E 16 $(340)^{*}, \quad$ E $15(800)^{*}$, E 13 (260)*, E 12 (20)*, E 10 (Pr.), E 8 (2), E $7(540)^{*}$, E 6 (Pr.), E $2(180)^{*}$, E 1 (375), V 1 (600), II 68 (33), III 322 (Pr.).

ECOLOGY - In our samples it was usually present in warm coastal water in 11 out of 31 samples, in warm surface shelf water in 8 out of 13 samples. Present also in two cold coastal water samples and in deep cold shelf waters in high percentages. Present only in six out of 31 tropical water open-sea samples. It was absent in surface subtropical waters. Farran (1929, p. 219) had numerous specimens taken off Rio de Janeiro by the "Terra Nova" Expedition and found it "the most plentiful of the larger species" inside the Great Barrier Reef, next to Undinula vulgaris, excepting during the cold months of "maximum 
salinity of the reef" (Farran 1936, p. 78). This corroborates our data, which show E. subcrassus as more numerous in warm coastal waters or in warm shelf waters. It was not present or present in small numbers in tropical and subtropical waters of high salinity. Therefore it may be classified in Brazilian waters as a thermophile eurythermic copepod which is also euryhaline, but prefers middle salinities, between 35.00 and $33.00 \%$. This explains why in the Pacific it is classified as "oceanic" (Yamazi 1958 , p. 147), because off Japan open-sea waters have a salinity range between the limits established above.

\section{Eucalanus monachus Giesbrecht}

Syn. E. vadicola F. Dahl 1894

(Fig. 10)

$$
\text { SIZE - } \sigma^{\star} 2.3 \mathrm{~mm} \text {; } \text { ๆ } 2.05 \mathrm{~mm} \text {. }
$$

OCCURRENCE - E 170 (240)*, E 164 (41), E 41 (20)*, E 32 (Pr.), E 30 (Pr.), E 28 (560)*, E 24 (Pr.), E 14 (20)*, E 13 $(260)^{*}$, E $12(20)^{*}, \mathrm{E} 11(280)^{*}$, E $9(20)^{*}, \mathrm{E} 8(20)$, E 7 $(160)^{*}, \mathrm{E} 4(180)^{*}$, E $3(920)^{*}, \mathrm{E} 1$ (75)*, P 10 (10), P 9 (18), P 7 (Pr.), P 3 (Pr.), P 1 (94), V 19 (510)*, V 13 (100), V 1 (100), M 261 (15), M 257 (32), M 208 (1), M 203 (1), M 190 (118), M 107 (16), M 78 (11), M 75 (121), М 39 (2), M 38 (164), M 35 (164), M 37 (3), M 30 (8).

Systematic Notes - F. Dahl recorded $E$. vadicola at the mouth of the Amazon River, characterizing it by a wider and flatter cephalon similar to that of the female of E. crassus, second furcal seta stronger than that of the European E. monachus, a fatter, not hairy last segment of the fifth pair of legs in the male and a shorter terminal spine than in the European E. monachus. Intermediate forms besides the described $E$. vadicola and $E$. monachus are present in the samples from coastal waters.

ECoLOGY - Apparently E. monachus is a very variable species which prefers coastal or shelf waters of salinities below $35.00 \%$. The samples in which it showed up always contained a water layer of salinities under $34.5^{\circ} \%$ and temperatures between $29^{\circ} \mathrm{C}$ and $20^{\circ} \mathrm{C}$. It was registered in 17 out of 31 samples of coastal water and in 5 out of 13 samples of surface shelf water. Bainbridge (1960, tab. 1) registered it in large numbers in the shelf waters of the Guinea Gulf. E. monachus and E. subcrassus are both characteristic of the neritic zone off the Brazilian coast and are among the species on which the coastal plankton-eating fishes feed (Table XII, p. 116). 


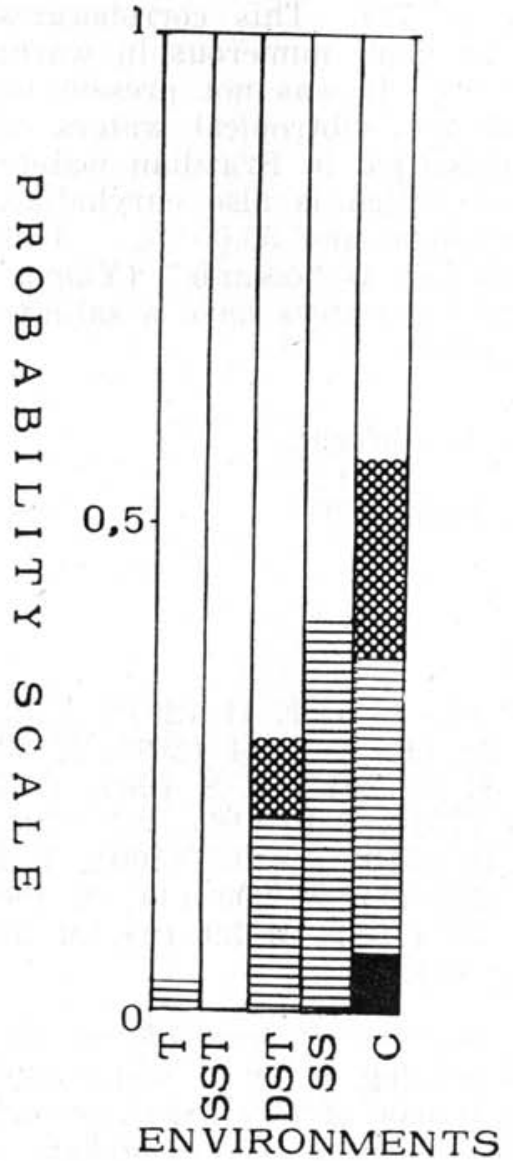

Fig. 10 - Probability of occurrence of Eucalanus monachus in different environments.
The Eucalanidae are probably an important constituent of the biomass present in our waters because of their great bulk. Fishes like 'oveva' (Larimus breviceps Cuvier) and 'corvina' (Micropogon furnieri Desmarest) have large numbers of Eucalanus in their stomachs, but usually not sufficiently well preserved so as to determine whether they are E. subcrassus or E. monachus (Table XII, p. 116).

\section{Other species of Eucalanus}

The following Eucalanus also occurred in the samples: one specimen of $E$. elongatus (Dana) in one sample (M 36); E. subtenuis Giesbr. in sample M 188 (4) and in sample M 389 (2); and $E$. crassus Giesbr. in four samples: M 33 (2 females); M 35 (1) ; M 36 (2) ; M 78 (13 specimens, among which adult females, males and copepodites).

These species were all found in shelf and subtropical waters. Off Brazil the Eucalanidae excepting $E$. attenuatus, seem to prefer the shelf and coastal waters and avoid the very saline waters of the open sea. This agrees with Fleminger (1959, p. 154) who considers E. pileatus as characteristic, together with Paracalanus parvus, of the neritic slope-facies in the Gulf of Mexico. In the Pacific, where the open sea waters are less saline (more or less $35.5 \%$ ) they are also found far from the coast (see Wilson 1950, p. 207-211; Yamazi 1958, p. 147; Vervoort 1946, p. 85-115). E. pileatus was registered by Bainbridge $(1960$, tab. 1) in large numbers in waters over the shelf in the Gulf of Guinea. It is probably a variety of E. subcrassus and is cited by some authors (Deevey 1960, p. 16-33) as E. pileatus-subcrassus.

E. elongatus is according to Farran's (1949, p. 218), Kusmorskaya (1959) and Wilson's (1950, p. 208-209) data an euryhaline 
and eurythermic cryophile open-sea copepod. Vervoort (1946, p. 85) registered $E$. elongatus in maximum numbers in 60 to $100 \mathrm{~m}$ depth layers in the Indo-Pacific, where temperatures are more or less between 20 and $25^{\circ} \mathrm{C}$ and salinities around $34.00 \%$ (Van Riel et al., 1950). It endures narrower salinity ranges than $E$. attenuatus and is therefore generally absent from our open sea waters.

\section{The species of Rhincalanus}

Schmaus \& Lehnhofer (1927, p. 392) summarized the known data on the distribution of the species of Rhincalanus (R. cornutus, $R$. nasutus, $R$. gigas) in the Atlantic and in the Indian Oceans. The study of Wilson's (1950, p. 318-319) and Farran's data (1929, p. 220) of samples taken in the Pacific Ocean show that the same distribution prevails there, with the difference that in the warmer months, $R$. cornutus reaches well into the Bering Sea, above $50^{\circ} \mathrm{N}$ Lat., further north than in the Atlantic. Farran (1929, p. 220) and Vervoort (1957, p. 33) registered the largest numbers of $R$. nasutus off the New Zealand and Australian waters where the salinity is around $35.5 \%$ and the temperature around 15 and $10^{\circ} \mathrm{C}$. The salinities in which $R$. cornutus and $R$. nasutus occurred in the Pacific were sometimes as low as $33.00 \%$ probably.

$R$. cornutus and $R$. nasutus seem to prefer open-sea waters (Farran 1936, p. 79) also off Brazil. $R$. cornutus is the most eurythermic of the two and the less cryophile.

\section{Rhincalanus cornutus (Dana)}

$$
\text { Size - o } 2.5 \mathrm{~mm} \text {; ㅇ } 3.5 \mathrm{~mm} \text {. }
$$

OCCURRENCE - M 497 (Pr.), M 368 (Pr.), M 365 (200)*, M 283 (1), M 246 (12), M 245 (1), M 240 (1), M 232 (1), M 113 (1), M 95 (1).

DISTRIBUTION - It occurred in samples of waters of high temperature $\left(25.5-28^{\circ} \mathrm{C}\right.$ ) and high salinity (more than $36.16 \%$ ) and in one shallow water sample where the deepest layer showed higher salinity in the region of the Amazon River's mouth. The samples were mostly from tropical waters. Dahl (1894, p. 3) registered it off the mouth of the Tocantins, but not further south off the Brazilian coast. Vervoort (1946, p. 121) found it in samples taken from 2,500 to $0 \mathrm{~m}$, usually in mid-water layers. The larger numbers of $R$. cornutus were registered by him between 60 and $200 \mathrm{~m}$ depths, in salinities around $34.50 \%$ and temperatures between 16.0 and $26.6^{\circ} \mathrm{C}$ approximately. 
Rhincalanus nasutus Giesbr.

Size — ᄋ $4.5 \mathrm{~mm}$.

OCCURRENCE - M 80 at $27^{\circ} 09.4^{\prime} \mathrm{S}$ and $47^{\circ} 16.5^{\prime} \mathrm{W}$ on September $26^{\text {th }}, 1955(12.40 \mathrm{~h})$.

ECOLOGY - It only occurred in sample M 80, which was not included in the general list, with salinities between 36.01 to $35.24 \%$ and temperatures from 14.01 to $20.99^{\circ} \mathrm{C}$. The fact that it usually occurs in deeper layers and does not migrate apparently during the day (Vervoort 1946, p. 126) explains its rare presence in our samples. It had not been previously recorded in Brazilian waters. The haul was made with a closing net from $125 \mathrm{~m}$ depth up to the surface, and the animal was probably swimming in the deeper layer when caught.

Thus Rhincalanus nasutus, contrary to Steuer's (in Sewell 1948, p. 365) idea, occurs in the western part of the South Atlantic, but probably in deep cooler layers.

\section{Mecynocera clausi I. C. Thompson}

(Fig. 11)

\section{SIZE - +1.0 to $1.1 \mathrm{~mm}$.}

OCCURRENCE - M 510 (1), M 497 (2), M 451 (Pr.), M 409 (41), M 407 (4), M 403 (164), M 402 (160), M 400 (Pr.), M 395 (108), M $394(1080)^{*}$, M 368 (3), M $365(400)^{*}$, M $364(240)^{*}$, M 363 (Pr.), M 315 (48), M 314 (7), M 247 (2), M 246 (7), M 245 (1), M 244 (2), M 243 (1), M 242 (2), M 241 (3), M 240 (16), M 236 (1), M 208 (1), M 189 (24), M 187 (1), M 186 (2), M 173 (1), M 166 (1), M 163 (116), M 162 (77), M 161 (327), M 160 (74), M 114 (11), M 113 (6), M 112 (4), M 99 (14), M 97 (1), M 96 (1), M 78 (7), M 76 (3), M 74 (1), M 39 (2), M 36 (3), M 35 (4), M 31 (3), P 13 (Pr.), P 12 (7), P 11 (3), P 10 (4), P 9 (6), P 8 (Pr.), P 7 (5), P 6 (1), P 5 (Pr.), P 4 (5), P 3 (2), P 2 (15), P 1 (Pr.), E 4 (1), E 3 (8).

ECOLOGY - It was present in nearly all samples of the most saline and warm waters off Brazil. It was found in higher percentages $(20.7-4.7 \%)$ in colder very saline waters $(36.00 \%$ or more) and in cool coastal waters with $22^{\circ} \mathrm{C}$ temperature or less. It had been registered in Brazilian waters before (Carvalho 1952, p. 137). Farran (1929, p. 221) and Heinrich (1960, 
p. 33) found its largest numbers in subtropical waters in the Pacific in the latitudes above $30^{\circ} \mathrm{S}$ and in temperatures between $21^{\circ} \mathrm{C}$ and $15^{\circ} \mathrm{C}$ (Sverdrup et al. 1948 , chart II and III). It is considered by Deevey (1952, p. 90) as characteristic of the Gulf Stream and of warm waters (Deevey 1952b, p. 156). It also occurs on the south African side of the Atlantic, where it was among the most frequent and abundant copepods in subtropical waters (Table $\mathrm{X}$ ). It is a surface copepod, because it did not occur in the samples collected in deep layers and its environmental optimum lies in cooler temperatures between 18 and $10^{\circ} \mathrm{C}$ (Fig. 11).

Heinrich (1961, p. 83, tab. 1) found it in large numbers off southern Japan in the 25-30 m deep layers during the day. During the night it was caught in deeper layers from 50 to $200 \mathrm{~m}$. It is not usually found at the surface $(20-0 \mathrm{~m})$ probably because the 18 to $10^{\circ} \mathrm{C}$ optimum of temperature is found in deeper layers in that region.

Fam. Paracalanidae G. O. Sars

According to Hensen (1911, p. 307) Paracalanus must be chiefly neritic for it made up almost half of the total of the Tocantins region copepod fauna.

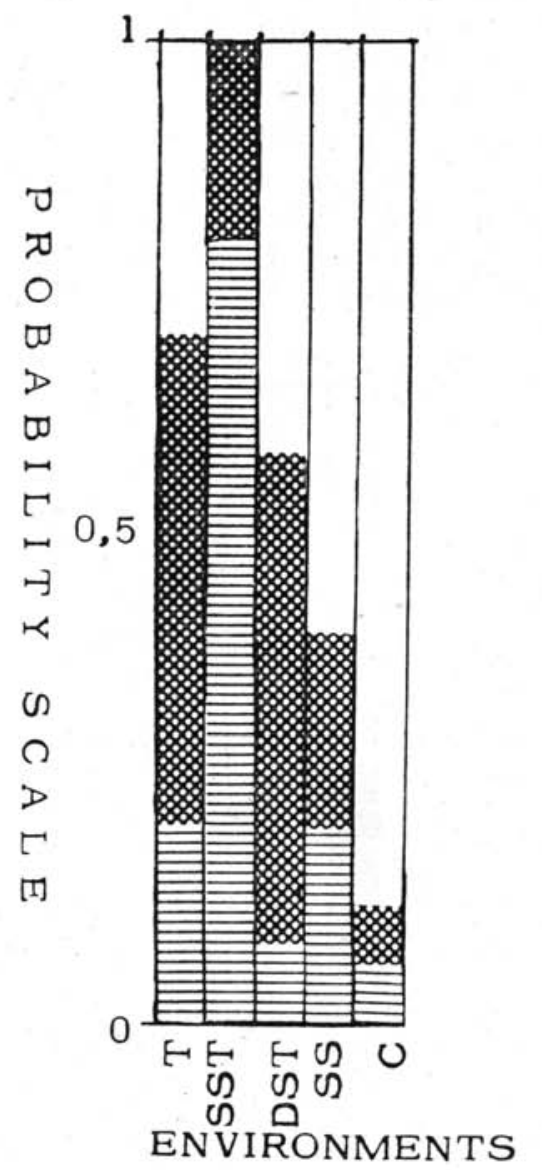

Fig. 11 - Probability of occurrence of Mecynocera clausi in different environments.

\title{
Paracalanus aculeatus Giesbr.
}

(Fig. 12)

\author{
Size - ơ $1.2-1.0 \mathrm{~mm}$; $+1.2 \mathrm{~mm}$.
}

OCCURRENCE - M 513 (300)*, M 510 (29), M 489 (60)*, M 451 (6), M 407 (Pr.), M 400 (89), M 389 (80)*, M 365 (160)*, M 283 (7), M 265 (3), M 257 (2), M 247 (292), M 246 (4), 
M 245 (2), M 244 (23), M 241 (4), M 240 (32), M 236 (177), M 208 (1), M 190 (157), M 189 (223), M 188 (10), M 173 (6), M 160 (6), M 114 (11), M 112 (2), M 107 (16), M 99 (7), M 98 (62), M 97 (6), M 96 (2), M 95 (17), M 93 (6), M 88 (9), M 78 (51), M 75 (31), M 74 (20), M 73 (5), M 39 (6), M 38 (57), M 37 (16), M 36 (52), M 35 (165), M 33 (7), M 31 (6), M 30 (18), II 68 (62), P 17 (Pr.), P 15 (Pr.), P 14 (Pr.), P 13 (39), P 12 (212), P 11 (19), P 10 (31), P 9 (53), P 8 (Pr.), P 7 (11), P 6 (18), P 5 (14), P 4 (22), P 3 (8), P 2 (140), P 1 (11), E $170(180)^{*}$, E $164(72)$, E $41(60)^{*}$, E 39 (1660)*, E 32 (40)*, E $30(160)^{*}$, E $28(3740)^{*}$, E $24(120)^{*}$, E $16(3380)^{*}$, E 15

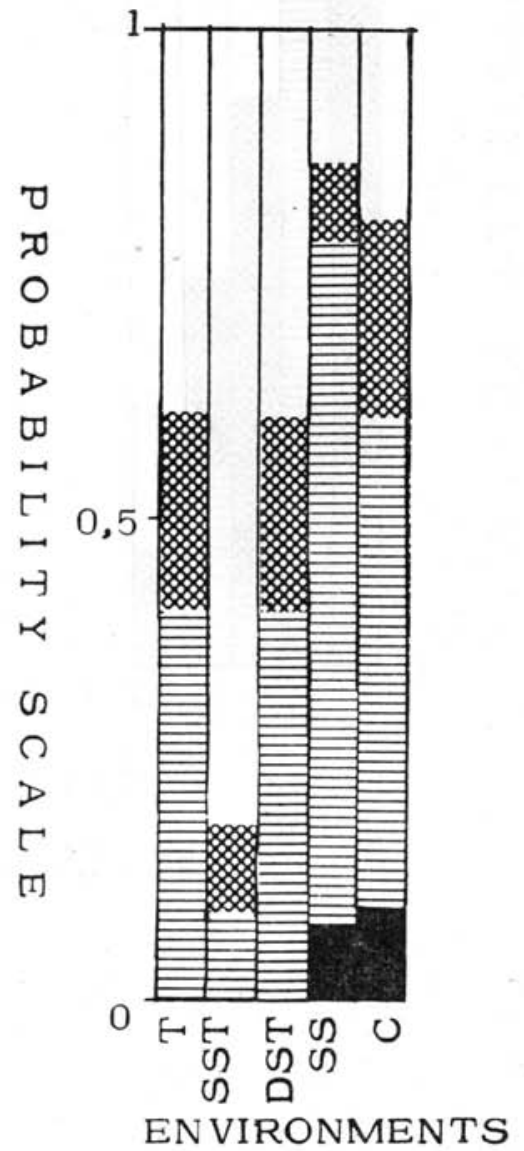

Fig. 12 - Probability of occurrence of Paracalanus aculeatus in different environments. $(4860) *$, E $14 \quad(300) *$, $\quad$ E 13 $(500) *$, E $12(3500) *$, E 11 $(1200) *$, E $10(1040) *$, E 9 (35), E 8 (5), E $7(900)^{*}$, E 5 (880)*, E 4 (17), E 3 (380)*, E 2 (11), V 13 (60)*, V 3 (Pr.), V 2 (Pr.), V 1 (Pr.), III 320 (2), III 321 (4), IV 218 (2).

ECology - It was one of the most frequent, though not numerous copepod in samples of water of high salinity (above $36.00 \%$ and high temperature (above $20^{\circ} \mathrm{C}$ ). In samples of high salinity and low temperatures (less than $20^{\circ} \mathrm{C}$ ) it was not very frequent. It was present in samples from surface layers of low salinity (under $35.00 \%$ ) and temperatures ranging from 18 to $28^{\circ} \mathrm{C}$. It was dominant or subdominant among the copepods in coastal and shelf waters of low salinity. It was registered before off Rio de Janeiro and at the mouth of the Tocantins (Vervoort 1946, p. 129). Farran (1929, p. 222 ; 1949 , p. 297$)$ recorded the largest numbers of this copepod in the tropical region. It seems to prefer surface and coastal or shell waters off Brazil. It is an eurythermic thermophile copepod. 


\section{$-27-$ \\ Paracalanus parvus (Claus)}

(Fig. 13)

SIZE $-\sigma^{\top} \quad 1.0-0.95 \mathrm{~mm}$; $ᄋ \quad 0.75-1.1 \mathrm{~mm}$.

OCCURRENCE - M 497 (11), M 365 (240)*, M 315 (232), M 314 (6), M 286 (10), M 283 (10), M 265 (6), M 208 (71), M 203 (1), M 190 (1), M 188 (136), M 186 (2), M 173 (45), M 163 (27), M 162 (882), M 161 (1), M 107 (4), M 89 (102), M 88 (60), M 76 (6), M 75 (43), M 74 (151), M 73 (16), M 38 (25), M 37 (1), M 35 (25), M 31 (5), M 30 (5), P 14 (Pr.), P 13 (7), P 12 (55), P 11 (2), P 10 (10), P 9 (59), P 8 (Pr.), P 7 (8), P 6 (1), P 5 (Pr.), P 4 (Pr.), P 3 (Pr.), P 2 (2), P 1 (10), E $170(60)^{*}$, E 164 (2), E $39(680)^{*}$, E $28(220)^{*}$, E 15 (140)*, E 12 (80)*, E 11 (100)*, E 9 (12), E 7 (60)*, E 5 (2820) *, E $4(380) *$, E $3(10,900) *$, E 2 (908)*, E 1 (3450)*, V 19 $(3150) *, V 13(260) *, V 1$ (340), II 68 (113), IV 244 (53), III 320 (8), III 321 (31).

ECOLOGY - $P$. parvus was dominant in four samples where the salinities varied from 36.19 to $34.11 \%$ and the temperatures from 27.5 to $17.76^{\circ} \mathrm{C}$. It is possible that this small copepod was not more numerous in more samples because it may pass through the meshes of the zooplankton net. $P$. parvus only occurred in one sample from exclusively warm layers. In all samples where it was dominant there were layers of colder water where the copepod probably thrived. It was found in large numbers among the copepods of a sample of coastal relatively very cold water $\left(14.38^{\circ} \mathrm{C}\right)$ from the south of Brazil. It has been recorded in the Atlantic, Pacific and Indian Ocean and also in the Arctic and

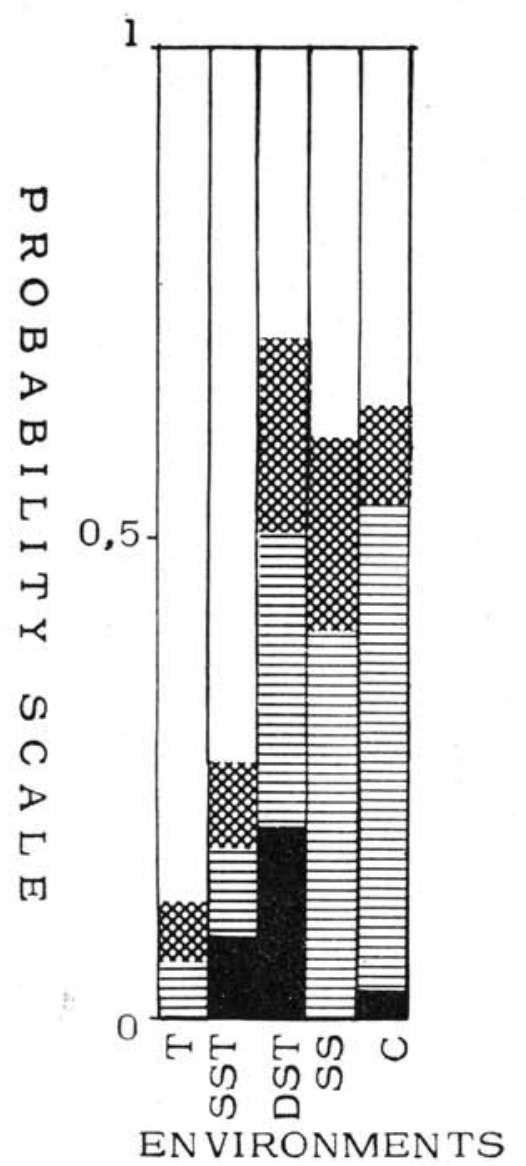

Fig. 13 - Probability of occurrence of Paracalanus parvus in different environments. 
Antarctic regions (Vervoort 1946, p. 131) in oceanic, coastal and brackish waters. It can be found in deep waters but prefers the surface (Vervoort 1946, p. 132) though in our samples it appeared in larger frequency and number in deep shelf waters (Fig. 13). It seems to prefer cooler temperatures, while Paracalanus aculeatus seems to prefer warmer waters as is also pointed out in Farran's study (1949, p. 297) of Australian waters. Like Clausocalanus arcuicornis it is abundant in the North Atlantic where it may indicate Atlantic waters (Wiborg 1954, p. 68). In the African waters near Fernando Po (Bainbridge 1960, tab. 1) it was subdominant in the shelf-oceanic facies.

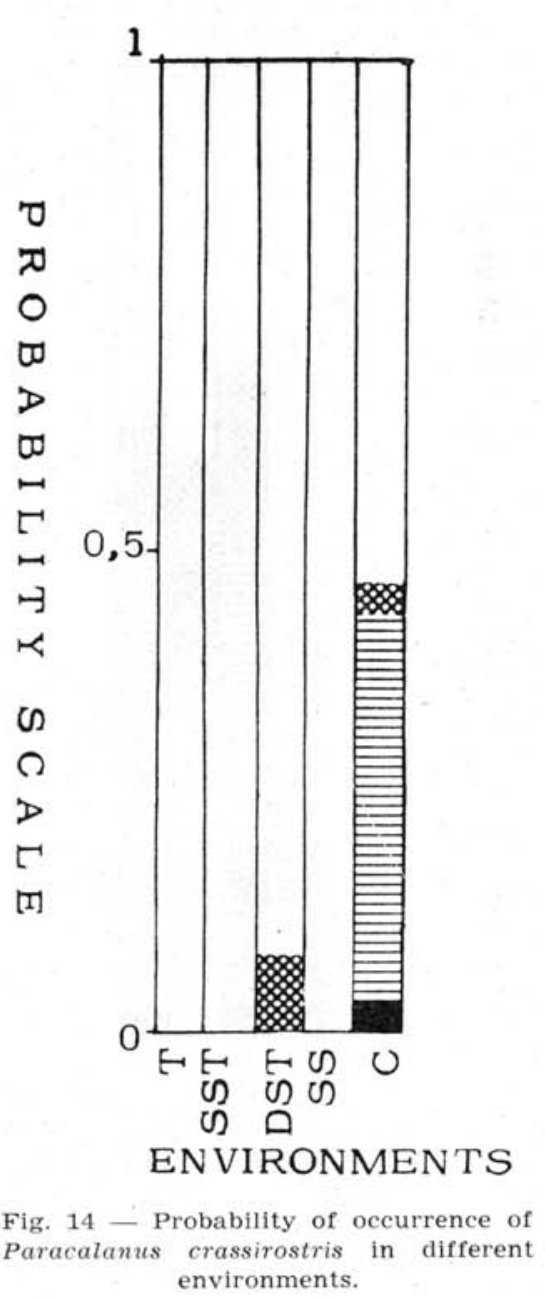

Paracalanus crassirostris Dahl

(Fig. 14)

Size - $0.5 \mathrm{~mm} ; \sigma^{*} 0.5 \mathrm{~mm}$.

OCCURRENCE - M 283 (9), M 238 (3), M 208 (10), M 203 (108), E $39(4540) *$, E $32(60) *$, E $30(120) *$, E $28(1320)^{*}$, E 14 (60) *, E $13(20) *, \operatorname{E~} 12$ (1360)*, E 10 (740)*, E 8 (2), E 7 (22), E $5(560)^{*}$, E $4(800)^{*}$, II 68 (191), III 322 (29), III 321 (117), III 320 (Pr.), IV 244 (37), IV 218 (60).

ECOLOGY - It is a well known coastal water copepod. Table IV summarizes the data obtained in several regions of the world. In Brazilian waters it was observed only in coastal or mixed coastal and shelf waters and once in deep shelf waters near the coastal region (Table XV).

It occurs in waters from salinities $55.00 \%$ in the $\mathrm{Suez} \mathrm{Ca}$ nal (Gurney 1927, p. 147) to $3.4 \%$ in the Chilka Lake (Devasundaram \& Roy 1954, p. 53), and in temperatures between 1 and $30^{\circ} \mathrm{C}$. It is extremely eurythermic and euryhaline, but stenoecius and therefore a good "indicator" species of coastal waters. 


\section{$-29-$ \\ Calocalanus pavo Dana}

(Fig. 15)

\section{Size - $+1.2-0.65 \mathrm{~mm}$.}

OCCURRENCE - M 513 (12), M 510 (4), M 497 (44), M 489 (2340), M 451 (40), M 409 (1), M 403 (40), M 400 (11), M 394 (40), M 389 (Pr.), M 368 (2), M 363 (Pr.), M 314 (Pr.), M 247 (45), M 246 (50), M 244 (37), M 243 (21), M 242 (11), M 241 (38), M 240 (22), M 232 (120), M 190 (4), M 163 (6), M 162 (6), M 161 (10), M 160 (14), M 113 (1), M 112 (2), M 111 (1), M 100 (2), M 98 (11), M 97 (1), M 96 (1), M 95 (Pr.), M 75 (7), M 74 (6), M 39 (6), M 38 (21), M 37 (1), M 36 (3), M 35 (15), M 33 (3), E 41 (2).

ECOLOGY - This species was never dominant among the copepods of the samples examined here, though present in large numbers, generally in salinities above $36.00 \%$ and temperatures above $25^{\circ} \mathrm{C}$. Its numbers diminished or it disappeared completely in samples of the same salinities but with temperatures under $25^{\circ} \mathrm{C}$. It occurred in small numbers in some samples where the salinities were under $36.00 \%$ and the temperatures under $26.3^{\circ} \mathrm{C}$. Thus it seems that this species prefers waters of high salinity and high temperature off Brazil. It did not occur in deep waters. In the Pacific (Wilson 1950 , p. 179) it was found only in less saline tropical waters, but also in the cold waters of the Bering Sea, though rarely. Its maximum numbers in the Pacific were found at $0^{\circ}$ Lat. and between 30 and $40^{\circ} \mathrm{S}$ (Heinrich 1960 , p. 33). Though recorded in the western south Atlantic (Sewell 1948, p. 450), it had not been found off our southern coast.

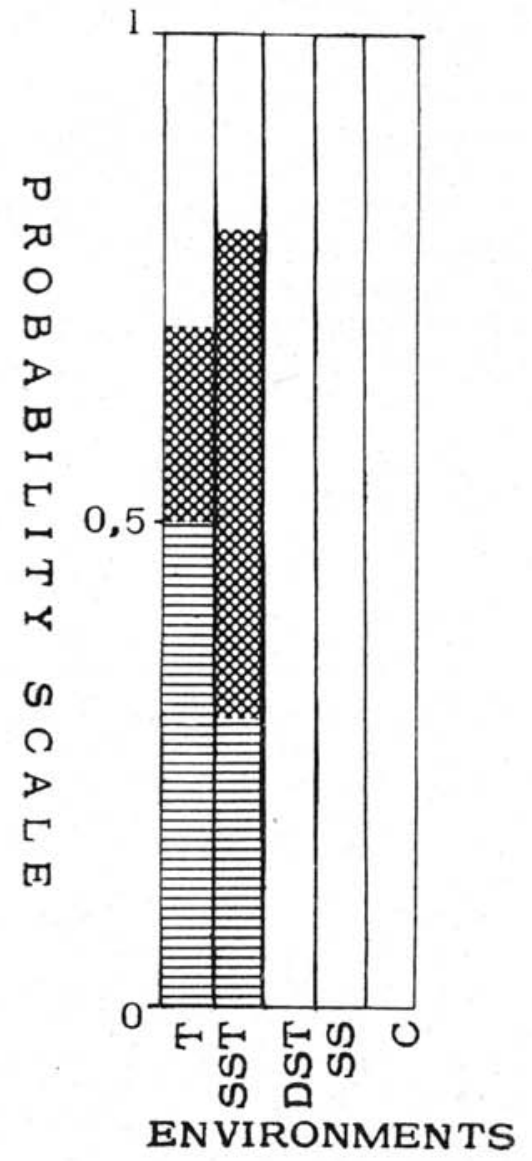

Fig. 15 - Probability of occurrence of Calocalanus pavo in different environments. 
Calocalanus styliremis Giesbr.

SIZE $-\sigma^{\star} \quad 0.65 \mathrm{~mm}$; $+0.6-0.7 \mathrm{~mm}$.

OCCURRENCE - M 513 (12), M 510 (20)*, M 497 (34), M 489 $(300)^{*}$, M $451(60)^{*}$, M 407 (1), M 402 (40)*, M 400 (16), M $394(40)^{*}$, M 389 (120)*, M 368 (2), M 365 (Pr.), M 364 (240), M 363 (Pr.), M 315 (107), M 314 (47), M 232 (40)*, M 208 (5), M 190 (5), M 187 (Pr.), M 100 (Pr.), M 96 (1), M 78 (3), M 75 (7), M 74 (6), M 39 (6), M 38 (21), M 36 (3), M 35 (20), M 33 (3), E 41 (40), E 24 (Pr.), P 10 (Pr.).

REMARKS - A very small species, usually caught by the nets of finer meshes. Registered off the Brazilian coast for the first time.

It occurred in samples of oceanic water of high salinity (above $36.00 \%$ ) and temperatures above $18^{\circ} \mathrm{C}$, but Farran $(1929$, p. 222) found the largest numbers of this species in cooler waters 15 to $21^{\circ} \mathrm{C}$, according to Sverdrup et al. 1942 , charts II and III. Yamazi (1958, p. 148) registers it as an oceanic, tropical species in Japanese waters. Wilson $(1950$, p. 180) found it in the Pacific Ocean, but it was less frequent than $C$. pavo perhaps because the nets used had larger meshes.

\section{Calocalanus plumulosus (Claus)}

Syn. Calocalanus tenuis Farran

$$
\text { Size - }+0.9 \mathrm{~mm} \text {. }
$$

OCCURRENCE - M $513(180)^{*}$, M 510 (40)*, M 497 (271), M $489(420)^{*}$, M $451(140)^{*}$, M $402(160)^{*}$, M 400 (18), M 389 (360)*, M 365 (200), M 364 (360)*, M 363 (Pr.), M 315 (Pr.), M 314 (15), M 238 (1), M 232 (2), M 208 (1), M 203 (1), M 189 (1), M 166 (Pr.), M 163 (2), M 162 (Pr.), M 114 (1), M 97 (1), M 88 (1), M 75 (4), M 74 (2), M 73 (2), M 38 (2), E 8 (29), E 4 (1), II 68 (5), III 320 (1).

REMARKs - Recorded here for the first time from Brazilian waters and probably quite common, but not usually caught by the nets of larger meshes because of its small size. It seems to prefer oceanic waters and cooler temperatures (see Farran 1929, p. 223). Both C. styliremis and C. plumulosus were registered in shelf and slope waters off the North American coast (Grice \& Hart, 1961). Heinrich (1961, tab. 2) found it concentrated in the surface layer at night and during the day in the $15-100 \mathrm{~m}$ layer or deeper between 23 and $35^{\circ} \mathrm{N}$ and 144 and $150^{\circ} \mathrm{W}$ Long. 


\title{
The Acrocalanus species
}

The genus Acrocalanus has 5 species. Only one was identified with certainty in our samples Acrocalanus longicornis Giesbr.

Acrocalanus longicornis Giesbr.

SIZE $-\sigma^{*} 0.95-0.8 \mathrm{~mm}$; i $1.1 \mathrm{~mm}$.

OCCURRENCE - M 497 (16), M 489 (120)*, M 451 (20)*, M 407 (5), M 368 (3), M 365 (40)*, M $364(80)^{*}$, M 363 (1), M 315 (15), M 314 (6), M 247 (3), M 246 (41), M 245 (37), M 244 (11), M 243 (18), M 242 (38), M 241 (195), M 240 (94), M 232 (40), M 190 (1), M 160 (6), M 114 (1), M 113 (3), M 100 (2), M 99 (22), M 98 (38), M 97 (12), M 95 (Pr.), M 78 (4), M 76 (6), M 75 (6), M 74 (77), M 73 (42), M 38 (25), M 37 (15), M 36 (8), M 35 (13), M 33 (2), M 32 (1), M 31 (3), P 10 (57).

ECOLOGY - It occurred in samples of very warm and very saline waters (salinities above $36.00 \%$ and temperatures above $25^{\circ} \mathrm{C}$ ). It diminished in frequency and percentage in colder very saline waters (temperatures under $25^{\circ} \mathrm{C}$ ). It was not present in samples from colder (under $20^{\circ} \mathrm{C}$ ) or deep water layers. It was present in samples from coastal waters. A. longicornis and A. gracilis are surface copepods and the first is an euryhaline, thermophile species. In the Pacific where very warm open-sea waters show smaller salinities it is a constant member of the copepod association. The genus is represented there by three or more species: A. gibber, A. monachus, A. gracilis, A. longicornis (Wilson 1950, p. 368-369; Scott 1909, p. 28-30). Off our coast it seems to prefer higher salinities. In the subtropical North-West Pacific A. longicornis prefers the surface, excepting near midday when it concentrates in layers 10-100 m deep (Heinrich 1961, tab. 2).

\section{Fam. Pseudocalanidae}

\section{Clausocalanus furcatus (Brady)}

(Fig. 16)

\author{
SIZE - o $0.85 \mathrm{~mm}$; क $1.25-1.75 \mathrm{~mm}$. \\ OCCURRENCE - M 513 (720)*, M 510 (560)*, M 497 (683), \\ M $489(18,480)^{*}$, M $451(1740)^{*}$, M $409(227)$, M $407(34)$, \\ M $403(1840)$, M $402(2440) *$, M 400 (8), M 395 (51), M 394
}


$(11,920)^{*}$, M 389 (2440) *, M 368 (21), M 365 (70), M 364 (116), M 363 (109), M 315 (478), M 314 (108), M 247 (361), M 246 (328), M 245 (145), M 244 (454), M 243 (95), M 242 (102), M 241 (259), M 240 (125), M 232 (760), M 208 (80), M 190 (446), M 189 (219), M 188 (1042), M 187 (441), M 186 (22), M 173 (23), M 166 (513), M 163 (6), M 160 (274), M 114 (13), M 113 (67), M 112 (2), M 107 (51), M 100 (93), M 99 (474), M 98 (1557), M 97 (130), M 96 (57), M 95 (38), M 93 (315), M 78 (107), M 76 (107), M 75 (474), M 74 (499), M 73 (10), M 39 (40), M 38 (335), M 37 (315), M 36 (279), M 35 (268), M 33 (34), M 32 (13), M 31 (6), M 30 (11), E 170 (20)*, E 164 (30), E $41(20)^{*}$, E 24 (20) *, E 16 (120)*, E 15 (2880)*, E 14

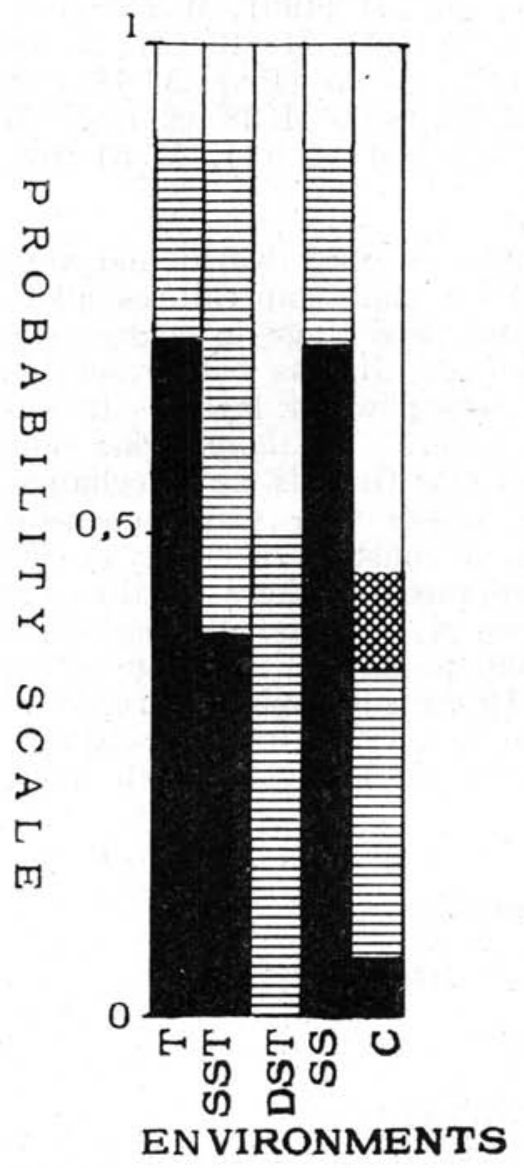

Fig. 16 - Probability of occurrence of Clausocalanus furcatus in different environments.
$(30) *$, E $13 \quad(2000)^{*}$, E 12 $(100)^{*}$, E $11(3020)^{*}$, E 8 (3), E 7 (97), E 4 (20)*, E 3 (1060) *, P 13 (6), P 12 (5), P 11 (4), P 10 (14), P 9 (4), P 7 (1), P 5 (1), P 4 (18), P 3 (4), P 2 (26), V 13 (20)*, V 3 (Pr.), II 68 (31).

ECOLOGY - The present study reveals this species as one of the most numerous in our high salinity surface waters, but it also occurs in all other environments studied here. It is usually the dominant species among the copepods of waters of more than $35.00 \%$ salinity and $25^{\circ} \mathrm{C}$ temperature. The histogram shows it to be dominant also in waters of lower temperatures (under $25^{\circ} \mathrm{C}$ ), but the number of samples in which it occurs in highest numbers diminishes with the temperature. Fleminger (1959, p. 154) considered the oceanic shelf facies in the Gulf of Mexico as characterized by Clausocalanus furcatus and Undinula vulgaris. It is a dominant copepod species in Tropical Water of the Brazil Current and of the South Equatorial Current. It indicates the influence of tropical or shelf water on coastal waters when present 
in large numbers. The fact that Clausocalanus prefers waters of higher salinities explains its smaller frequency in samples from the Pacific (Wilson 1950, p. 190; Heinrich 1961, tab. 2). Kusmorskaya (1960, p. 147, tab. 5) found Clausocalanus as one of the most frequent copepods in the N. Atlantic Intermediate Zone. Hensen (1911, p. 308) registered the maximum numbers of Clausocalanus during the "Plankton" Expedition in the "Brazilian Coastal Current" and in the mouth of the Tocantins River, off the North of Brazil. It showed the maximum concentration in surface layers during the day in the North West subtropical Pacific (Heinrich 1961, tab. 2).

\section{Clausocalanus arcuicornis Dana}

(Figs. 17, 18)

\section{SIZE - o $1.3 \mathrm{~mm}$; क $0.8 \mathrm{~mm}$ and 1.5 to $1.65 \mathrm{~mm}$.}

OCCURRENCE - M 497 (1), M 409 (1), M 407 (Pr.), M 403 (2480), M 402 (80), M 365 (Pr.), M 363 (1), M 314 (6), M 247 (19), M 246 (8), M 245 (1), M 244 (21), M 242 (9), M 241 (7), M $240(10)$, M 363 (1), M 166 (513), M 163 (22), M 161 (890), M $160(1) *$, M 98 (2), M 78 (8), M 75 (5), M 37 (1), M 36 (3), E 1 $(50) *$.

Systematic Notes - Both the "major" and "minor" forms were observed in the same sample. In one sample in which the species was very abundant (M 161) the great majority of the specimens belonged to the form "minor". Both forms were mature females with

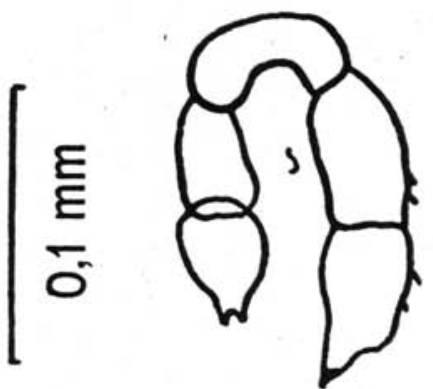

Fig. 18 - Clausocalanus arcuicornis: abnormal fifth pair of legs. sizes distinctly different $(0.8$ and $1.65 \mathrm{~mm}$ ). In sample M 242 one of the specimens showed an abnormal fifth pair of legs (Fig. 18).

Ecology - It was observed (Fig. 16) that while C. furcatus prefers warmer waters with salinities above $36.00 \%$, C. arcuicornis, stouter than the first when mature, prefers colder waters of slightly lower salinities, around $35.00 \%$ (Fig. 17). Thus it is found in the Gulf Stream (Wheeler 1900, p. 171). It indicates Atlantic water off Norway during Summer and Autumn (Wiborg 


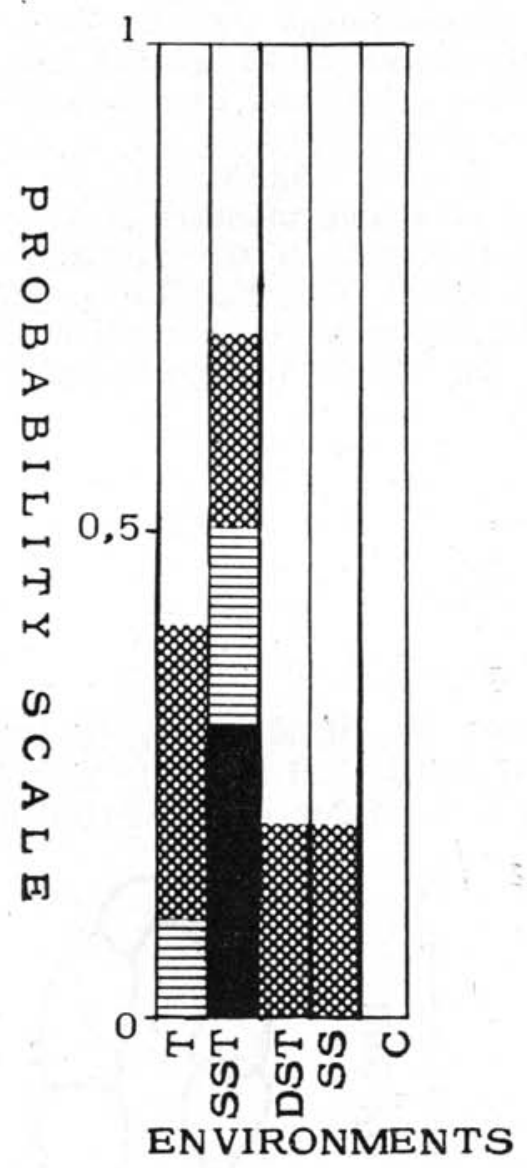

Fig. 17 - Probability of occurrence of Clausocalanus arcuicornis in different environments.
1954, p. 167). Kusmorskaya $(1959 ; 1960$, p. 147) lists it among the most numerous species of the transition zone between boreal and southern warm water species in the North Atlantic, so it really seems to be a surface species of cool saline waters. Heinrich (1961, tab. 2) registered its greatest numbers by day in the $25-50 \mathrm{~m}$ and at night in the $50-100 \mathrm{~m}$ depth in the subtropical North Pacific.

In the Pacific it is more frequent than $C$. furcatus (Scott 1909, p. 32; Wilson 1950 , p. 190 ; Brodsky 1957, p. 55; Heinrich 1961, tab. 2) perhaps due to the lower salinities of the waters. It was abundant in South African subtropical oceanic waters and in the same waters in the middle South Atlantic. Vervoort (1946, p. 141) registered C. arcuicornis frequently and in larger numbers than $C$. furcatus in the deeper layers $(150-300 \mathrm{~m})$ of the IndoPacific, where temperatures are between 10 and $18^{\circ} \mathrm{C}$ and salinities around $34.5 \%$ and (Vervoort 1957, p. 37) also in the surface layers $(50-0 \mathrm{~m})$, of $12.6^{\circ} \mathrm{C}$ and $35.2 \%$ at $44^{\circ} 05 ' \mathrm{~S}$ and $147^{\circ} 35^{\prime} \mathrm{E}$ in the Pacific.

\section{Ctenocalanus vanus Giesbrecht}

(Fig. 19)

SizE - o $1.25-1.33 \mathrm{~mm}$; क $1.1-1.25$ and $1.5 \mathrm{~mm}$.

OCCURRENCE - M 389 (520)*, M 238 (17), M 236 (34), M 208 (20), M 189 (9), M 186 (9), M 173 (25), M 166 (4), M 114 (2), M 89 (112), M 88 (391), M 78 (235), M 76 (215), M 75 (162), M 74 (123), M 73 (48), M 38 (18), M 35 (716), 
E $170(20) *$, E $39(20)^{*}$, E $5(21,600)^{*}$, E $4(1020) *$, E 3 $(6340) *$, E $2(5960) *$, E 1 (2150)*, V $13(900) *$, V 19 (2490)*, V 1 (2520), V 2 (Pr.).

Systematic Notes - Ctenocalanus vanus has at least two different forms in our waters - one with longer and one with shorter antennae. It also has a larger and smaller form. The larger is of colder waters.

DISTRIBUTION - C. vanus
has been reported from the Atlantic, the Pacific, the Antarctic, the Mediterranean and the Red Sea regions (Tanaka 1956 , p. 384). It was also recorded in the Western South Atlantic (Sewell 1948, p. 450).

ECOLOGY - This animal occurs in very large numbers in all samples where at least one of the layers fished had salinities ranging from 36.00 to $35.00 \%$ and temperatures under $22^{\circ} \mathrm{C}$.

It was listed by Kusmorskaya (1959) as one of the species characteristic of the transition zone between boreal and southern warm water species in the Northern Atlantic. Like some other species listed from this zone, it lives in waters with the salinity and temperature characteristics of the Subtropical Water (Emilsson 1959, p. 46) off the Brazilian coast. It occurs usually in the deeper layers of the waters which cover the continental shelf, but it may appear at the surface too, when this

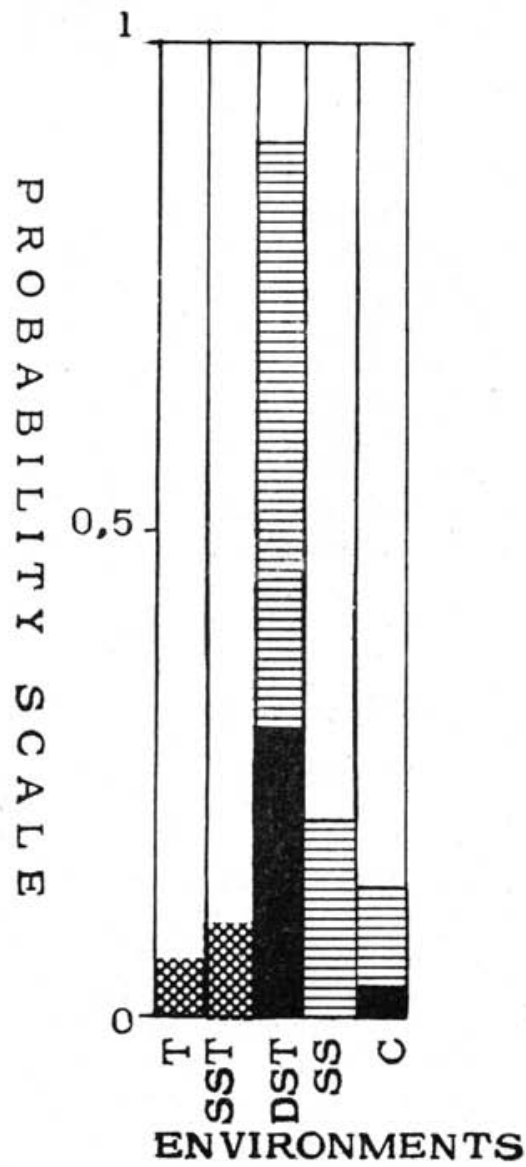

Fig. 19 - Probability of occurrence of Ctenocalanus vanus in different environments. water is upwelled.

It occurred (Fig. 19) in two samples of low salinity (under $33.22 \%$ ) and temperatures $\left(15.4\right.$ to $\left.14.38^{\circ} \mathrm{C}\right)$, in coastal southern waters, and was dominant in the two samples of deep cold shelf water ( V 1, V 19). The greatest number of this copepod per haul was taken by the "Terra Nova" Expedition (Farran 1959, 
p. 226) in the Antarctic shelf or coastal waters. The fact that Vervoort (1957, p. 37) also registered many specimens of this species during the B.A.N.Z.A.R. Expedition in "waters bordering the Antarctic continent" and not in oceanic waters, shows that it prefers coastal or shelf environments. It is therefore an euryhaline and eurythermic species, but strongly cryophile, a good indicator of colder water off Brazil, though considered as an indicator of warm water in the North Pacific (Brodsky 1950, p. 120).

\section{Fam. Aetideidae}

Representatives of this family were rare and unfrequent, but their presence in the samples is important, because being deep water copepods with vertical migration habits they are a proof that a different association lives in deeper layers on the edge of the shelf or just off the shelf, under the waters of the Brazil Current. In the list of species Aetideid sp. 1 and Aetideid sp. 2 refer to two different males and several females belonging to species of this family. The specimens were rather mutilated and therefore not yet described. They all come from deep layers at the edge of the shelf (sample M 78).

\section{Undeuchaeta major Giesbr.}

$$
\begin{aligned}
& \text { SIZE - o } 3.0-3.5 \mathrm{~mm} \text {; } \circ 3.5-4.0 \mathrm{~mm} \text {. } \\
& \text { OCCURRENCE - M } 161 \text { (1), M } 114 \text { (11). }
\end{aligned}
$$

REMARKS - Sample M 161 was collected at the surface (0-50 m) at 23:50 P.M. in $36.26-36.10 \%$ salinity and temperatures between 18.18 and $17.56^{\circ} \mathrm{C}$, thus corroborating the observations of the following authors. According to Wolfenden (as in Sewell 1948, p. 512) and Brodsky (1950, p. 183) this is a deep-dwelling species belonging to a "subtropical or warm temperate area". Farran (1926, p. 254) recorded it in the Bay of Biscay in small numbers regularly in the night epiplankton.

\section{Euaetideus giesbrechti (Cleve)}

$$
\text { Size — o } 1.5 \mathrm{~mm} \text {; o } 1.1 \mathrm{~mm} \text {. }
$$

OCCURRENCE - M 395 (1), M 368 (1), M 88 (1), M 78 (2), M 76 (5), M 75 (1).

Remarks - It is also a deep-dwelling copepod in the Mediterranean Sea (Sewell 1948, p. 507-508) recorded for the first time in Brazilian waters. 
Three samples in which it occurred were taken during the night, two of which in the deeper layers of the shelf water (M 78 and $M$ 76) and one (M 75) in the surface layers $(0-50 \mathrm{~m})$, thus partially confirming Sewell's observations. It was also present in a sample from cold coastal water $\left(15.40-15.18^{\circ} \mathrm{C}\right)$ in the south of Brazil and in a sample taken from very saline and warm water $\left(25.21-24.54^{\circ} \mathrm{C}\right)$ during the day. In this sample it is probably a stray from deeper layers.

\section{Euchirella rostrata (Claus)}

\section{SIZE - $+3-3.5 \mathrm{~mm}$.}

\section{OCCURRENCE - M 166 (18), M 76 (2).}

REMARKS - Farran (1926, p. 215) recorded its presence only at 300 fathoms depth or more. According to Sewell (1948, p. 507508) and Brodsky (1950, p. 174), it is a deep-dwelling copepod. It is registered off the Brazilian coast for the first time in two samples from very saline and from cooler water, taken during the night and in the early morning, suggesting night vertical migration to the surface. M 76 is a sample taken from deeper water $(95$ to $50 \mathrm{~m})$ over the shelf.

\section{Euchirella brevis Sars}

$$
\text { Size - } \odot 3.0 \mathrm{~mm} \text {; ơ } 2.9 \mathrm{~mm} \text {. }
$$

$$
\text { OCCURRENCE - M } 247 \text { (6), M } 245 \text { (1), M } 244 \text { (2). }
$$

REMARKs - Recorded for the first time in Brazilian waters. A deep-dwelling species, probably caught at the surface due to its migration to upper layers during the night.

\section{Fam. Euchaetidae}

Euchaeta marina (Prestandr.)

(Fig. 20)

$$
\begin{aligned}
& \text { Size }- \text { o } 2.8-3.0 \mathrm{~mm} \text {; o } 3.3 \mathrm{~mm} . \\
& \text { OCCURRENCE }- \text { M } 513(180)^{*} \text {, M } 510(120) * \text {, M } 497 \text { (38), } \\
& \text { M } 489(1380)^{*} \text {, M } 451(40)^{*}, \text { M } 409 \text { (Pr.), M } 407(4), \text { M } 403
\end{aligned}
$$


(6), M $402(120)^{*}$, M 395 (20), M 389 (Pr.), M 368 (1), M 364 (Pr.), M 363 (3), M 315 (50), M 314 (21), M 247 (248), M 246 (46), M 245 (38), M 244 (79), M 243 (60), M 242 (93), M 241 (9), M 240 (9), M 232 (80), M 163 (3), M 162 (4), M 161 (6), M 160 (1), M 114 (33)*, M 113 (4)*, M 112 (3), M 111 (2), M 99 (2), M 78 (1), M 76 (22), M 75 (5), M 38 (1), M 37 (32), M 36 (13), M 35 (2), M 33 (3).

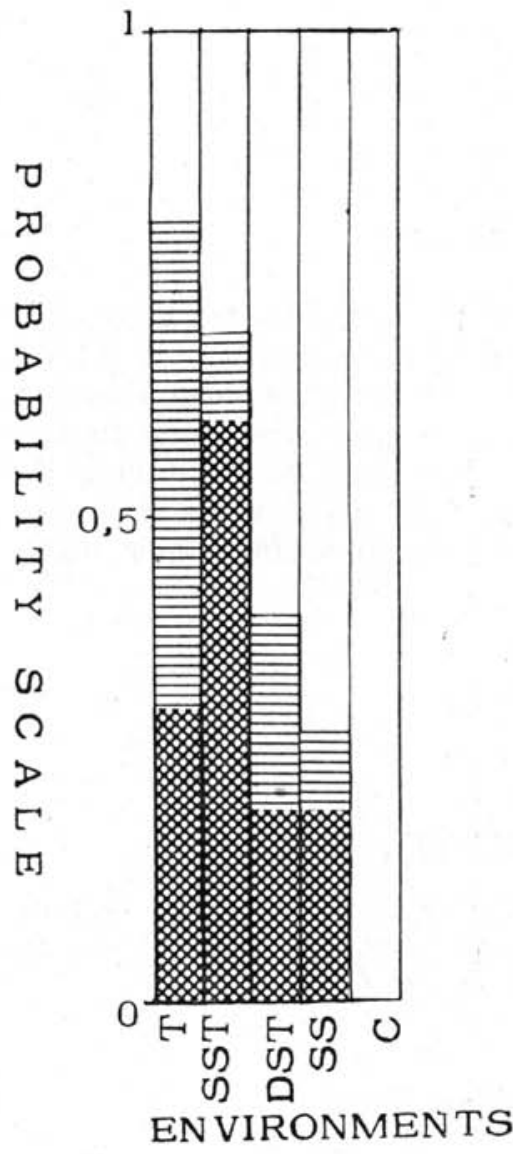

Fig. 20 - Probability of occurrence of Euchaeta marina in different environments.
Distribution - Already known off the Amazon River's mouth (Dahl 1894, p. 12) off Rio de Janeiro, off Vitória and off the coast of Bahia (Farran 1929, p. 237). It has also been registered off the Atlantic coast of Africa (Marques 1958, p. 210). The present data enlarge its distribution in Brazilian waters to $34^{\circ} 42^{\prime} \mathrm{S}$ and to $04^{\circ} 57^{\prime} \mathrm{N}$.

ECOLOGY - The study of its distribution in the Pacific (Wilson 1950, p. 355-430) shows that E. marina occurs frequently not only in waters usually of low. salinity $(33.00 \%$ off Central America, Colombia and Panama) but also that it is among the frequent copepods in the Bering Sea and off Alaska, where temperatures are usually as low as $7^{\circ} \mathrm{C}$. This was not confirmed by Brodsky (1959, p. 116-117) who found $E$. marina to be characteristic of tropical and transition zones in the Pacific (Brodsky 1957, p. 55-56).

The histogram (Fig. 20) shows Euchaeta marina as a copepod which prefers warm, very saline waters, therefore thermophile. Deevey (1952b, p. 157) classifies it as a warm water copepod and Farran (1929, p. 237) as a "common tropical species". As it did not occur in coastal waters it is preferentially a shelf oceanic species in Brazilian waters. It occurred in small quantities 
or not at all in the samples from deeper layers: therefore a surface copepod. The same has been established by Heinrich (1961, p. 87) in the Pacific: the species only migrates to the $25-100 \mathrm{~m}$ layers during the day. At night it lives at the surface.

\section{Euchaeta acuta Giesbr.}

\section{SIZE - $+4.5-4.0 \mathrm{~mm}$; $\sigma^{\star} 4 \mathrm{~mm}$.}

OCCURRENCE - M 315 (1), M 166 (13), M 161 (15), off the South African Coast.

REMARKS - Rare in our samples this copepod seems to prefer cooler waters ( 18.44 to $17.56^{\circ} \mathrm{C}$ ) for it is also listed by Kusmorskaya (1959) as one of the species of the transition zone between boreal and southern warm water in the North Atlantic. It was found here for the first time off the South African Atlantic coast. Farran (1929, p. 237) found it sometimes in large numbers off New Zealand and in the Bay of Biscay (Farran 1926, p. 257). Euchaeta hebes is another copepod of the same genus which is considered characteristic of temperate waters (Fleury 1950, p. 48), whereas Paraeuchaeta norvegica is characteristic of deep and very cold water in the North Atlantic $\left(35.00 \%\right.$ and 7 to $\left.10^{\circ} \mathrm{C}\right)$. Bogorov (1958, p. 151) lists Paraeuchaeta japonica in boreal waters (3 to $15^{\circ} \mathrm{C}$ ), E. marina and E. acuta in tropical waters (from 18 to $27^{\circ} \mathrm{C}$ ) in the North Pacific and all three species in the zone of mixing of these waters $\left(15\right.$ to $18^{\circ} \mathrm{C}$ ). Bogorov's (1958, p. 150) opinion is that no distinct subtropical fauna exists but our data are against it, confirming Brodsky's (in Bogorov 1958, p. 150) point of view that such an association does exist. E. acuta was only found in cooler very saline surface waters off the Brazilian coast and seems to belong to this association in the South Atlantic.

\section{Fam. Scolecithriciidae}

Scolecithrix danae (Lubb.)

(Fig. 21)

$$
\text { SIZE - क } 2.1 \mathrm{~mm} \text {; } \sigma^{\top} 1.9 \mathrm{~mm} \text {. }
$$

OCCURRENCE - M 513 (6)*, M 510 (15), M 497 (3), M 489 (2820)*, M 451 (8), M 409 (5), M 407 (23), M 403 (20), M 402 (40)*, M 400 (Pr.), M 395 (17), M 394 (200)*, M 389 (160)*, M 368 (6)*, M 365 (1), M 364 (1), M 363 (1), M 315 (37), 
M 314 (28), M 247 (7), M 246 (29), M 245 (39), M 244 (31), M 243 (24), M 242 (18), M 241 (50), M 240 (10), M 232 (40)", M 166 (3), M 163 (5), M 162 (2)*, M 161 (4), M 160 (4), M 114 (8), M 113 (6), M 112 (3), M 111 (4), M 100 (1), M 99 (10), M 98 (2), M 97 (1), M 95 (5), M 93 (1), M 78 (9), M 76 (1), M 75 (1), M 74 (9), M 38 (1), M 37 (17), M 36 (7), M 35 (4).

Distribution - It was registered before off the Brazilian coast between $23^{\circ} 30^{\prime} \mathrm{S}$ and $01^{\circ} 00^{\prime} \mathrm{N}$ (Farran 1929, p. 243; Dahl 1894, p. 3). The present study enlarges its distribution to $04^{\circ} 57^{\prime}$ $\mathrm{N}$ and to $32^{\circ} 24^{\prime} \mathrm{S}$ off the Brazilian coast.

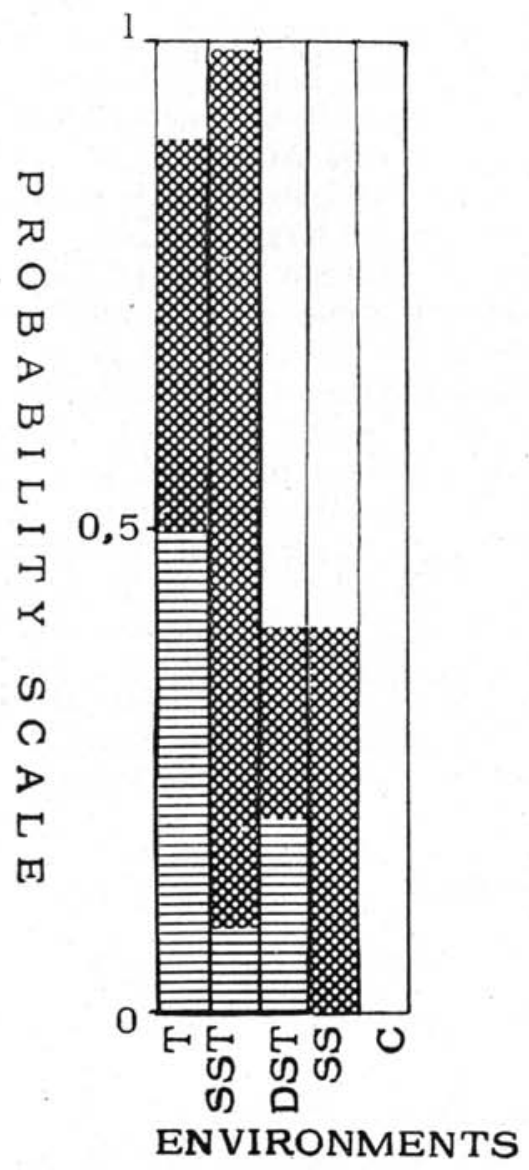

Fig. 21 - Probability of occurrence of Scolecithrix danae in different environments.
ECOLOGY - The histogram shows that this animal prefers salinity above $36.00 \%$ and high temperatures (above $25^{\circ} \mathrm{C}$ ) in waters off Brazil. In waters of less than $25^{\circ} \mathrm{C}$ the number of specimens diminishes. It does not appear in purely coastal waters. The same was verified by Farran (1929, p. 243). Marques (1953, p. 104) registered this species off the African coast of Angola, where the mean August temperature lies between 16 and $20^{\circ} \mathrm{C}$ (Chart III, Sverdrup et al., 1948) . It is found here in $16.51^{\circ} \mathrm{C}$ and $35.3^{\circ} \%$ at $32^{\circ} 49.5^{\prime} \mathrm{S}$ and $16^{\circ} 56^{\prime}$ E (Table XVI). Suarez-Caabro (1959, tab. III) recorded this species off Pinos Is. in the Caribbean in waters of temperatures between 25.0 and $29.5^{\circ} \mathrm{C}$ and salinities from 32.82 to $36.91 \%$. It occurs in the Gulf Stream (Sewell 1948, p. 463) and in the Counter-Equatorial Current (Sewell 1948, p. 457). In the Pacific Ocean this animal occurs in larger numbers in warm equatorial waters where salinities are around $35.5 \%$ and temperatures about $27.5^{\circ} \mathrm{C}$ on the surface (Heinrich 1960, tab. 2). It is also frequently present in waters with salinities between 32.00 and $34.00 \%$ and temperatures as 
low as $7^{\circ} \mathrm{C}$ in the Bering Sea (Wilson 1950, p. 335) though not confirmed by Brodsky (1957, p. 113-124). It is therefore a copepod which lives in shelf and oceanic waters and may appear in coastal waters. It lives in the $0-100 \mathrm{~m}$ deep layer in the NorthWest subtropical Pacific (Heinrich 1961, p. 87). It is very euryhaline and eurythermic and strongly thermophile off the Brazilian coast. When associated to Clausocalanus furcatus and Corycella gracilis it is usually indicator of tropical or Brazil Current waters off our coasts.

Scolecithricella dentata (Giesbr.)

SIZE - $+1.2 \mathrm{~mm}$.

OCCURRENCE - M 78 (8), M 76 (1), M 75 (1).

REMARKS - It was registered before at stations 50 and 59 of the "Terra Nova" Expedition in the South Atlantic tropical region by Farran (1929, p. 247). Farran (1926, p. 259) observed that this animal ascends to about $50 \mathrm{~m}$ depth during the night and lives at $400 \mathrm{~m}$ depth during the day. The present specimens come from a haul taken with a closing-net from 108 to $54 \mathrm{~m}$ depth at night (M 78). Its distribution is enlarged here to $25^{\circ} 45.5^{\prime} \mathrm{S}$, off the Brazilian coast. It is probably part of the deep-dwelling fauna of the waters on the edge of the shelf.

\section{Lophothrix latipes (Scott)}

SIZE - $\quad 3 \mathrm{~mm}$.

OCCURRENCE - M 395 (1 \%).

REmarks - This deep-sea copepod (Sewell 1948, p. 546; Brodsky 1950 , p. 245 ) was collected in a haul from $274 \mathrm{~m}$ to the surface over a depth of $3,180 \mathrm{~m}$. The salinities of the layers sampled are from 36.04 to $35.53 \%$ and the temperatures are from 20.52 to $14.80^{\circ} \mathrm{C}$ in the deepest layer $(300 \mathrm{~m})$. This animal is here recorded for the first time off the southern coast of Brazil at $33^{\circ} 02^{\prime} \mathrm{S}$.

Scaphocalanus curtus (Farran)

Syn. Scolecithrix curta Farran, 1926

(Fig. 22)

SIZE - ơ $0.95 \mathrm{~mm}$; $+1.0 \mathrm{~mm}$. 


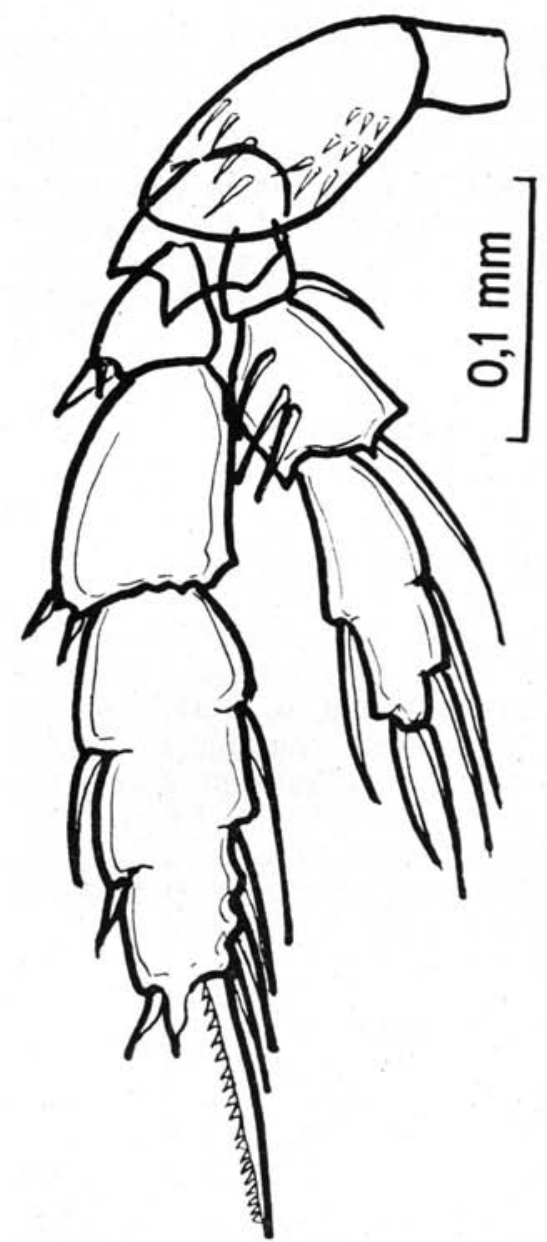

Fig. 22 - Scaphocalanus curtus: Fourth leg.

$$
\text { OCCURRENCE - M } 395 \text { (1), }
$$
M 78 (4), M 76 (2).

REMARKS - Although the animals were not in excellent conditions, they were entire. An accurate drawing of the fourth legs (Fig. 22) was made. They have several groups of spines on the first basipodite. The second joint of the endopodite of the fourth legs also shows two rows of spines. The other anatomical features correspond exactly to the description of Farran (1929, p. 259-260).

ECOLOGY - It is a deepdwelling copepod and was caught in a haul made with a closingnet between 108 and $54 \mathrm{~m}$ in the deeper shelf waters over the slope, with salinities 35.77$35.10 \%$ and temperatures 17.53$12.48^{\circ} \mathrm{C}$, therefore subtropical Atlantic water. The animal probably died as the subtropical water was raised over the shelf, as it probably does not live in a shallow habitat. It is an indicator of deep water, registered here for the first time in Brazilian waters.

\section{Fam. Centropagidae}

Centropages furcatus (Dana)

(Fig. 23)

$$
\text { Size - o } 1.6-1.75 \mathrm{~mm} \text {; } ᄋ 1.9 \mathrm{~mm} \text {. }
$$

OCCURRENCE - M 389 (520)*, M 283 (11), M 265 (1020)", M 261 (2), M 257 (52), M 236 (1), M 208 (6), M 203 (1), M 190 (42), M 188 (2), M 187 (1), M 173 (7), M 114 (2), M 107 (5), 
M 100 (Pr.), M 95 (1), M 88 (2), M 78 (6), M 76 (12), M 75 (15), M 74 (7), M 73 (13), M 39 (9), M 38 (115), M 36 (9), M 35 (54), M 33 (7), M 32 (2), M 31 (16), M 30 (17), E 170 (100)*, E $164(18)$, E $39(260)^{*}$, E 28 (40)*, E $24(40) *$, E 16 (160)*, E $15(440)^{*}$, E $13(140)^{*}$, E $12(180)^{*}$, E 11 (200)*, E 9 (9), E 7 (80)*, E 4 (60)*, E 3 (180)*, E 2 (20)*, E 1 (425)*, II 68 (18), P 13 (22), P 12 (31), P 11 (47), P 10 (17), P 9 (30), P 8 (6), P 7 (41), P 6 (84), P 5 (6), P 4 (34), P 3 (92), P 2 (53), P 1 (79), V 1 (Pr.).

Remarks - This copepod was recorded off Rio de Janeiro and Cabo Frio by Farran (1929, p. 255); as Manaia velificata, off Angra dos Reis, by Oliveira (1947, p. 466) ; off Santos (Carvalho 1952 , p. 145) and off Guaratuba (Carvalho 1944, p. 95).

ECOLOGY - The histogram shows that it is very abundant and usually present in low salinity waters, between 32.00 and $35.00 \%$ and temperature of $20^{\circ} \mathrm{C}$ or more. It did not appear in the cold very saline surface waters. It appeared sparingly in cold deep layers of the shelf waters and in three samples of very saline and warm tropical waters off Brazil. Yamazi (1958, p. 149) lists it as a warm-water form. It shows a distinct preference for coastal and shelf waters in our samples. Fleminger (1959, p. 154) places it along with Temora turbinata as the characteristic copepod of the "coastal neritic facies" in the Gulf of Mexico. Off the southern coast of Brazil it might be placed along with Temora stylifera as characteristic of the same facies. Off the African coast it is also very numerous in slope and shelf waters, along with Centropages chierchiae (Bainbridge 1960, tab. 1). Off New York, in the same facies it is substituted by Cen-

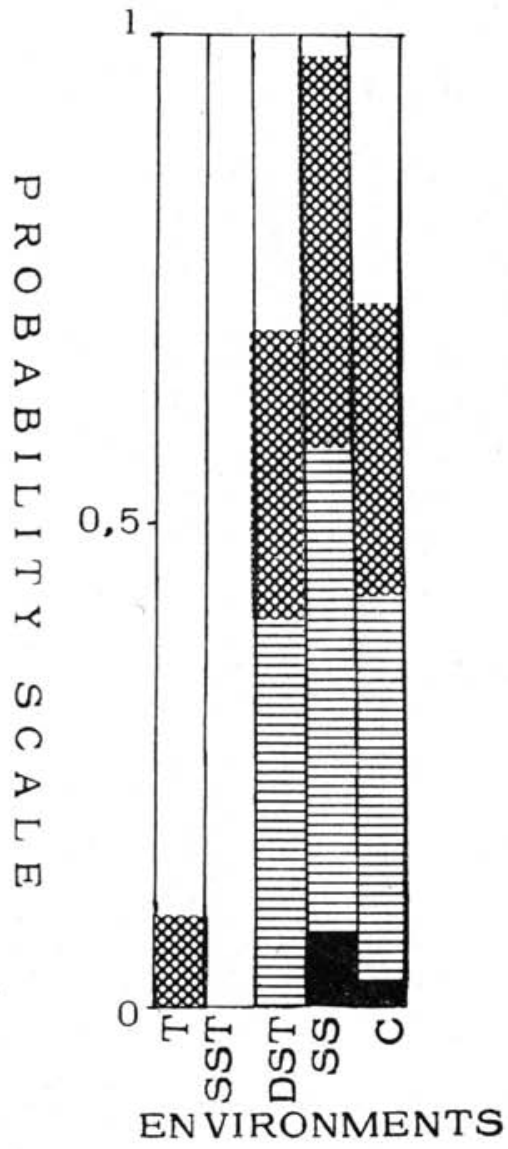

Fig. 23 - Probability of occurrence of Centropages furcatus in different environments. 
tropages typicus and Centropages bradyi (Grice \& Hart, unpublished manuscript). It occurs in the tropical and subtropical Pacific (Brodsky 1957, p. 55, p. 69-70).

\section{Centropages violaceus (Claus)}

(Fig. 24)

Size -0 \% $1.8 \mathrm{~mm}$; क $2.2 \mathrm{~mm}$.

OCCURRENCE - M 497 (3), M 489 (120)*, M 409 (Pr.), M 403 (3), M $402(40)^{*}$, M 394 (Pr.), M 368 (2), M 315 (1), M 247 (1), M 246 (11), M 245 (4), M 244 (7), M 243 (9), M 242 (16),

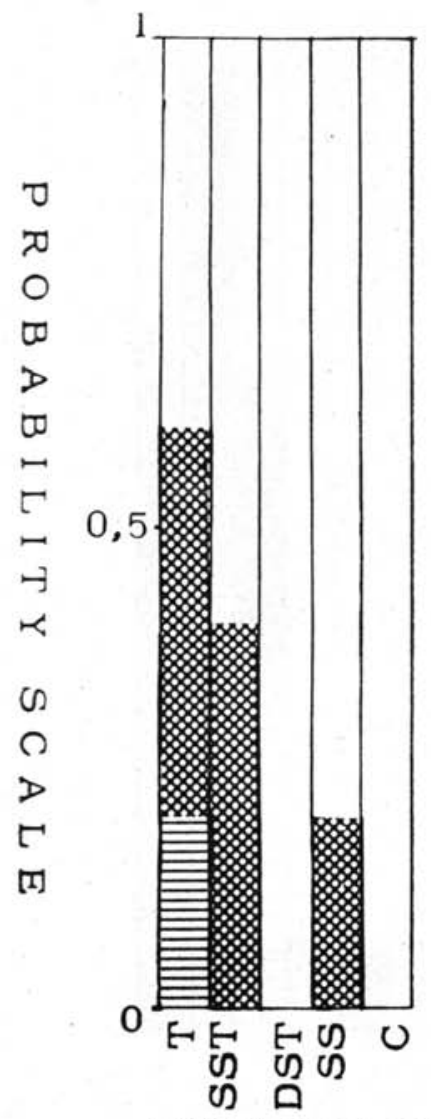

ENVIRONMENTS

Fig. 24 - Probability of occurrence of Centropages violaceus in different environments.
M 241 (6), M $240(3)$, M 114 (6), M 99 (4), M 98 (20), M 97 (5), M 38 (1), M 37 (7), M 36 (1), M 33 (2).

ECOLOGY - It is frequently found off Brazil but not numerously in warm very saline waters, perhaps by migration from deeper layers and is rarer as the water becomes cooler. Farran (1929, p. 255) also recorded its largest numbers in tropical waters. In very saline surface waters with temperatures under $20^{\circ} \mathrm{C}$, it occurred only in $3 \mathrm{samp}-$ les, the same as in samples from shelf waters. Absent in samples taken from deep, cooler waters and in samples from coastal waters off Brazil, but was found in the subtropical waters of the middle South Atlantic and off South Africa. It was registered in the Bering Sea in low temperatures and salinities by Wilson (1950, p. 358-363), but not by Brodsky $(1950 ; 1957)$.

Centropages brachiatus (Dana)

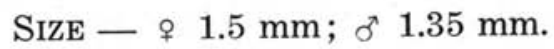

OCCURRENCE - M 89 (30), M 88 (36). 
DisTRIBUTION - It occurred abundantly only in two samples of low salinity (coastal water) and low temperature (under $15.18^{\circ} \mathrm{C}$ ) in large numbers. It seems to be more characteristic of the southern than of the northern hemisphere and is the only cryophile representative of the family found off Brazil for the first time, for Centropages furcatus and C. violaceus are thermophile, the first in the epipelagial neritic region and the second in the oceanic region.

Sewell (1948, p. 453) registers C. brachiatus in the region of the West Wind Drift, in the South Atlantic off the coast of South America and off the Cape of Good Hope and in the Gulf of Guinea off Africa (op. cit., p. 455). It is also mentioned as belonging to the waters of the North Atlantic (Sub-Arctic Atlantic sub-region of Steuer 1933, p. 293). It is not recorded in the Gulf Stream, in the Mediterranean and in the Caribbean Seas. It was recorded off the Pacific coast of South America where it is known that the water temperature is lower than off the Atlantic coast at the same latitudes.

\section{Fam. Diaptomidae \\ Pseudodiaptomus acutus (F. Dahl)}

Size - o 1.1-1.3 mm; ơ $0.85 \mathrm{~mm}$.

OCCURRENCE - M 283 (1), P 10 (Pr.), P 1 (3), IV 218 (20), IV 320 (5), III 320 (5), III 321 (44), III 322 (Pr.), E 39 (20)*, E $24(20) *$.

DisTRIBUTION - It had been registered before by Dahl (1894, p. 11) at the mouth of the Tocantins river in 11.8-12.8\% salinity and $28^{\circ} \mathrm{C}$ temperature at the surface. Carvalho (1952, p. 146) recorded its presence in the bay of Santos. Sewell (1948, p. 452) considers it as apparently indigenous of the east coast of South America and as apparently "evolved in the brackish water of the great river estuaries". The water column where it occurred showed a salinity between 8.255 and $35.87 \%$. It was more abundant near the surface in samples taken at different depths. It seems to characterize the estuarine facies and inshore waters on the Brazilian coast together with Labidocera fluviatilis F. Dahl. Copepodites and nauplii of $P$. acutus were found in great numbers in the inshore waters of Cananéia but not in the offshore shelf waters, where the adults are occasionally found. 


\section{Pseudodiaptomus richardi (F. Dahl)}

\section{SIZE — ᄋ $1.5 \mathrm{~mm}$; ơ $1.1 \mathrm{~mm}$.}

OCCURRENCE - M 269 (1).

DisTRIBUTION - It had been registered off the Amazon River's mouth by Dahl (1894, p. 4-5) and is again registered here in the same region. By Dahl's table (loc. cit.) this species is probably adapted to lower salinities than $P$. acutus.

\section{Fam. Temoridae}

Temora stylifera (Dana)

(Fig. 25)

\section{SIZE - $1.05 \mathrm{~mm}$; ơ 1.7 to $1.55 \mathrm{~mm}$.}

OCCURRENCE - M 497 (Pr.), M 407 (12), M 400 (1), M 389 $(560)^{*}$, M 368 (11), M 365 (400)*, M 364 (5), M 363 (3), M 314 (3), M 283 (21), M $265(600)^{*}$, M 257 (18), M 246 (14), M 243 (2), M 242 (5), M 241 (19), M 240 (88), M 238 (14), M 236 (11), M 232 (1), M 208 (35), M 203 (12), M 190 (79), M 189 (226), M 188 (15), M 187 (97), M 186 (60), M 173 (17), M 162 (5), M 160 (3), M 114 (18), M 113 (1), M 112 (1), M 111 (2), M 107 (2), M 100 (19), M 99 (116), M 98 (108), M 97 (17), M 96 (8), M 95 (159), M 93 (119), M 88 (2), M 78 (20), M 76 (12), M 75 (37), M 74 (38), M 73 (30), M 39 (10), M 38 (127), M 37 (35), M 36 (44), M 35 (36), M 33 (30), M 32 (8), M 31 (12), M 30 (10), E 170 (20)*, E 164 (60), E 41 (40)*, E 39 $(140)^{*}, \mathrm{E} 32(20)^{*}, \mathrm{E} 30$ (Pr.), E 24 (180)*, E 16 (1360)*, E 15 (680), E $14(20) *$, E 13 (900)*, E 12 (100), E 11 (700)*, E 9 (11), E 8 (32), E 7 (720)*, E 4 (4120)*, E 3 (12,720)*, E 2 (680)*, E 1 (1025)*, P 13 (90), P 12 (73), P 11 (154), P 10 (33), P 9 (104), P 8 (9), P 7 (7), P 6 (105), P 5 (29), P 4 (272), P 3 (210), P 2 (79), P 1 (52), V 13 (20)*, V 19 (510)*, V 3 (Pr.), V 1 (5), II 68 (20), III 321 (2), IV 244 (1), E $28(\mathrm{Pr})$.

Ecology - We find it to be the dominant species over other copepods in coastal waters with $33.00 \%$ salinity or more and in samples of shelf waters with layers of salinity around $35.00 \%$ and temperature above $20^{\circ} \mathrm{C}$ (Fig. 25). It is not usually found to be dominant in oceanic waters, thus, contrary to Deevey (1952b, p. 157) and Yamazi (1958, p. 150) it should be considered of 
coastal or of shelf-water preferences off the Brazilian coast. In the Pacific, oceanic waters are of lower salinities than here and therefore in that ocean T. stylifera is oceanic.

The other authors mentioned register it in subtropical or in waters with temperatures between 15 and $18^{\circ} \mathrm{C}$ more or less (Yamazi 1958, p. 150; Deevey 1952 b, p. 157). The most numerous occurrences, with many juvenile forms, examined here occurred in temperatures between 17 and $28.5^{\circ} \mathrm{C}$ in coastal and in shelf waters with salinities under $35.5 \%$. It was absent or occurred in low percentages in inshore waters. Thus, T. stylifera, though very euryhaline, seems to have an environmental optimum between 33.00 and $35.50 \%$. It has been found in the stomach contents of some fishes like "sardinha” (Sardinella allecia Raf.) and "oveva" (Larimus breviceps Cuv.) in dominant numbers.

It is a very common cosmopolitan copepod. Although present in the northern hemisphere, it occurs there less frequently and in smaller numbers, as can be seen from station lists like Farran's (1929, p. 258). Wilson $(1950$, p. 343$)$ registered it in the warm currents of the Pacific from $30^{\circ} \mathrm{N}$ down to $20^{\circ} \mathrm{S}$ and off Peru. The greatest number of specimens was recorded off Rio de Janeiro and Vitória, near the Tropic of Capricorn and it diminishes from latitude $15^{\circ} \mathrm{S}$ northwards. Bogorov (1958, p. 152) lits it in the mixing zone (temperatures from 15 to $18^{\circ} \mathrm{C}$ ) and in tropical waters (temperatures from 18 to $27^{\circ} \mathrm{C}$ ) in the northwestern Pacific epipelagial. Bainbridge (1960, tab. 1) lists it as one of the most numerous copepods "in hauls taken from $100 \mathrm{~m}$ to the surface along three sections of the shelf" in the Gulf of Guinea.

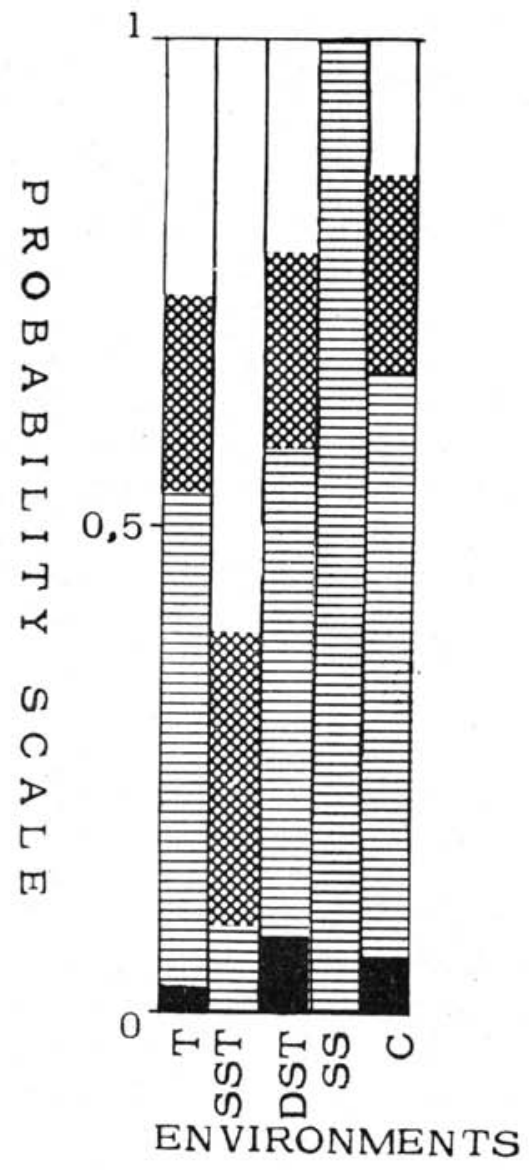

Fig. 25 - Probability of occurrence of Temora stylifera in different environments. 
Temeropia mayumbaensis $\mathrm{T}$. Scott

Size - $+1.0 \mathrm{~mm} ; \delta^{\circ} 0.9 \mathrm{~mm}$.

OCCURRENCE - M 78 (19), M 73 (4).

REMARKS - Registered here for the first time in Brazilian waters in two samples taken with closing-net from water layers between 54 and $108 \mathrm{~m}$ depth and in surface waters. It was also registered by Marques (1958, p. 214) off Angola. It is a deepwater copepod (Farran 1936, p. 110) and is probably part of the fauna of deep layers. Its presence in M 73 (a surface haul) can be explained through migrational movements. Heinrich (1961, p. 87) found it in large numbers in the North West Subtropical Pacific, where it was usually concentrated in the $50-100 \mathrm{~m}$ deep layer or near the surface during the day. At night it reached $500 \mathrm{~m}$ depth.

\section{Fam. Metridiidae}

The Pleuromamma of the Brazilian Coast

During the "Plankton" and the "Meteor" Expeditions the following Pleuromamma were registered in the Brazilian waters: Pleuromamma xiphias (Giesbr.) off the northern coast (the Tocantins mouth, Fortaleza, Cabo São Roque), off the eastern coast (Salvador) (Steuer 1932, p. 120, karte 1; 1937, p. 135-137), off the southern coast of Brazil (Rio Grande do Sul) (Steuer 1937, p. 134) ; P. abdominalis (Lubb.) off the northern coast of Brazil, Salvador, Rio (Steuer 1932, p. 120; 1937, p. 134, 137); P. quadrungulata (Dahl) off the northern coast of Brazil (Steuer 1932, karte $12 ; 1937$, p. 137) ; P. gracilis (Claus) off the northern coast of Brazil, off the eastern and the southern coast (Steuer 1932, karte $14 ; 1937$, p. 132-137) ; P. borealis (Dahl) off the northern coast of Brazil, off Rio Grande do Sul (Steuer 1937, p. 134-137). It seems that $P$. gracilis is the most common species of this genus off our coast. It is a deep-dwelling genus and not so common in our samples usually from the surface. The "Meteor" caught these animals frequently in the $0-100 \mathrm{~m}$ deep hauls in the south and from 600-400 $\mathrm{m}$ deep hauls off the Amazon in the north (see tables a-c in Steuer 1937, p. 134-137) off Brazil. P. robusta and $P$. quadrungulata were caught off the Brazilian coast only bet- 
ween 600 and $400 \mathrm{~m}$. That is perhaps the reason why they were not registered in any of the samples examined for this work, taken above $200 \mathrm{~m}$.

\section{Pleuromamma abdominalis (Lubbock)}

(Fig. 26)

\section{SIZE - $2.5-3.5 \mathrm{~mm}$; ơ $3.5-4 \mathrm{~mm}$.}

OCCURRENCE - M 510 (160)*, M 365 (5), M 232 (160)*, M 166 (30), M 114 (33), M 112 (2), M 111 (2), M 100 (3), M 76 (9), M 37 (1), M 36 (2).

ECOLOGY - All the specimens taken come from more than $35.00 \%$ salinity and $14-26.7^{\circ} \mathrm{C}$ temperature.

It was a very numerous species of copepod in two samples taken from waters of high salinity and temperatures between 21.44 and $26.70^{\circ} \mathrm{C}$. So it seems to prefer warmer oceanic or shelf waters, but under oceanic influence. It is a deep water form with vertical migratory habits (Moore 1949, p. 53). According to Brodsky $(1950$, p. 308) it is a warm water surface copepod. Heinrich (1961, p. 88) collected it at the surface only at night. Generally it was found deeper than $50 \mathrm{~m}$ in the subtropical region of the North West Pacific.

Farran (1926, p. 259) registered it off the continental shelf of the northern coast of Brazil in oceanic tropical waters. According to Wiborg (1954, p. 69) and Yamazi (1958, p. 150) it is a southern warm-water oceanic form in the northern hemisphere. It indicates Atlantic water off Norway.

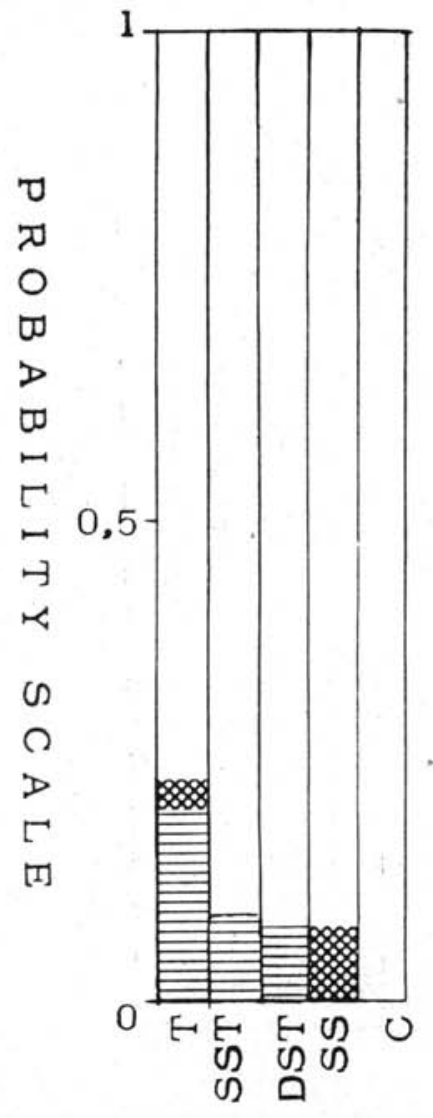

EN VIRONMENTS

Fig. 26 - Probability of occurrence of Pleuromamma abdominalis in different environments. 
Pleuromamma gracilis (Claus)

(Fig. 27)

\section{SIZE - $+2.0-1.9 \mathrm{~mm}$; o $1.8 \mathrm{~mm}$.}

OCCURRENCE - M 407 (1), M 403 (Pr.), M 395 (5), M 365 (5), M 232 (3), M 166 (2 f. piseki), M 162 (4), M 161 (70), M 114 (137), M 112 (2), M 111 (12), M 99 (18), M 78 (11), M 75 (14), M 74 (9), M 36 (3).

ECOLOGY - Here it occurred in samples of water of high salinities and temperatures under $24^{\circ} \mathrm{C}$ and it was more frequent

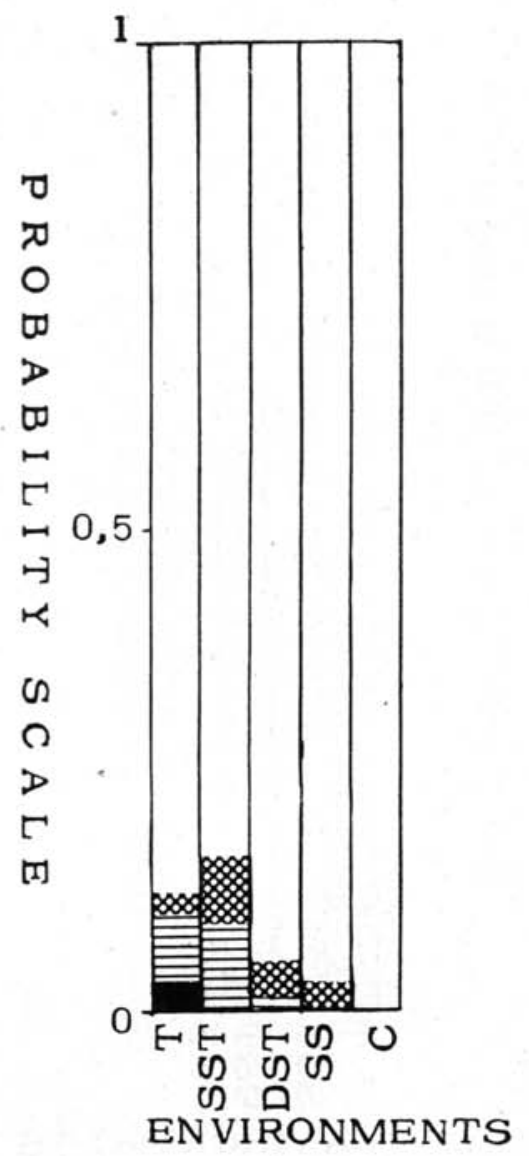

Fig. 27 - Probability of occurrence of Pleuromamma gracilis in different environments. in deep shelf water. Wilson (1950, p. 289) registered it in waters of lower salinity and Yamazi (1958, p. 150$)$ registers it as a "Temperate Water species" off Japan. It is a cryophile species off Brazil. Brodsky (1950, p. 309) classifies it as oceanic, bathypelagic and a warm water form, whereas $P$. abdominalis is relatively thermophile.

It was registered by Farran (1929, p. 260) and Wilson (1950, p. 353-354) off the Brazilian coast from Cabo Frio up to Fernando de Noronha. As Pleuromamma abdominalis it prefers deeper waters (Moore 1949, p. 54) and was caught only when surface samples were taken at night or early in the morning. According to Heinrich's (1961, p. 88) data it is found during the day concentrated at $500 \mathrm{~m}$ depth. It was caught in higher numbers (Farran 1929, p. 261) off New Zealand, in cooler waters, which it probably prefers. Kusmorskaya (1959) ranges it along with $P$. borealis, P. xiphias, $P$. abdominalis and $P$. robusta as characteristic of the transition zone between boreal and southern warm 
water species in the Atlantic. Brodsky (1957, p. 60) registers it as a characteristic copepod of the association found in the subtropical North Pacific.

\section{Pleuromamma borealis F. Dahl}

$$
\text { Size }-\circ 1.9-2.0 \mathrm{~mm} \text {. }
$$

$$
\text { OCCURRENCE - M } 166 \text { (9), M } 162 \text { (4). }
$$

REMARKs - It was thriving off the Brazilian coast in cooler waters $\left(17.76\right.$ to $\left.18.00^{\circ} \mathrm{C}\right)$ of high salinity. It was observed in samples off the South African coast in subtropical waters, during the night in surface hauls (Table XVI). An eurythermic cryophile species in the Atlantic. Our specimens are much smaller than those from the "Terra Nova" Expedition (Farran 1929, p. 262). It occurred there in cold waters of the sub-antarctic region (Sewell 1948, p. 513-515). It also occurs in the North Atlantic in the English Channel where waters are also cooler. Brodsky $(1950$, p. 310) classifies it as an oceanic bathypelagic species.

\section{Pleuromamma xiphias (Giesbr.)}

$$
\text { Size }-\sigma^{\star} 3.5 \mathrm{~mm} \text {; }+3.25-5.0 \mathrm{~mm} \text {. }
$$

$$
\text { OCCURRENCE - M } 166 \text { (3), M } 161 \text { (Pr.), M } 75 \text { (3). }
$$

ECOLOGY - It occurred in samples taken during the night from waters of high salinity (over $35.00 \%$ on ) and lower temperatures (under $20^{\circ} \mathrm{C}$ ), thus corroborating Moore's (1949, p. 54) data on the migration of the species to the surface layers during the night. It is registered off Brazil with smaller size than elsewhere.

\section{Fam. Lucicutiidae}

\section{Lucicutia flavicornis (Claus)}

(Fig. 28)

$$
\text { SIZE — o } 1.9-1.7 \mathrm{~mm} \text {; o } 1.25-1.5 \mathrm{~mm} \text {. }
$$

OCCURRENCE - M 510 (20)*, M 409 (Pr.), M 407 (8), M 403 (Pr.), M 402 (Pr.), M 400 (Pr.), M 395 (29), M 389 (160)*, 
M 368 (5), M 365 (280)*, M 364 (10), M 315 (Pr.), M 314 (2), M 304 (Pr.), M 283 (2), M 241 (1), M 240 (6), M 232 (8), M 166 (2), M 162 (5), M 161 (21), M 114 (8), M 112 (1), M 111 (19), M 100 (Pr.), M 99 (10), M 95 (Pr.), M 78 (10), M 76 (1), M 75 (18), M 74 (1), M 39 (2), M 38 (2), M 37 (11), M 36 (6), E 164 (1).

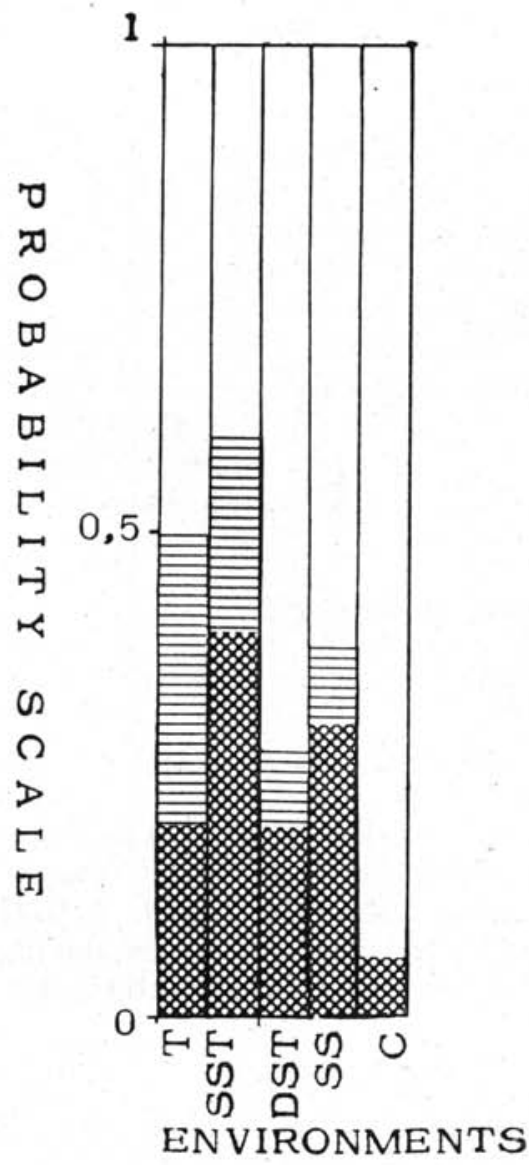

Fig. 28 - Probability of occurrence of Lucicutia flavicornis in different environments.
ECOLOGY - This species was found in 14 samples of water with high salinity (over $35.00 \%$ ) and temperatures below $21^{\circ} \mathrm{C}$ and in 10 samples from high salinity water and temperature from 24 to $21^{\circ} \mathrm{C}$. It was found only in 5 samples of water of high salinity and temperature between 25.20 and $27^{\circ} \mathrm{C}$. Thus it seems to prefer cooler waters. Of these it prefers the $25-50 \mathrm{~m}$ layers during the day (Heinrich 1961, p. 88$)$. Moore (1949, p. 56) registers it under $50 \mathrm{~m}$ in larger quantities in the Bermuda area, and Heinrich (loc. cit.) in the subtropical North West Pacific. Farran (1929, p. 263) registers the largest numbers of this species in the "North Temperate Atlantic" and in the southern hemisphere between 30 and $40^{\circ} \mathrm{S}$ off New Zealand where the waters are also cooler. Although listed by Yamazi $(1958$, p. 150) as a warm-water oceanic form, it is perhaps better to consider it as oceanic but as preferring the transition zone between warm and cold waters. Kusmorskaya (1959) places it more correctly among the transition zones species between the warm and the boreal water species. It was also registered by Wilson (1950, p. 255) in the Bering Sea although Brodsky (1957, p. 113-121) did not mention it among the typical Bering Sea copepods. 
Lucicutia ovalis Wolfenden

Size - $\quad 1.4 \mathrm{~mm}$.

OCCURRENCE - M 489 (60)*, M 407 (4), M 403 (3), M 400 (Pr.), M 395 (2), M 240 (1).

REMARKS - It occurred in oceanic waters of salinities above $35.53 \%$. It prefers deep waters (Sewell 1948, p. 521; Heinrich 1961, tab. 4). It is registered for the first time off Brazil.

\section{Lucicutia clausi (Giesbrecht)}

Size — $+1.95 \mathrm{~mm}$.

OCCURRENCE - M 407 (2), M $395\left(\begin{array}{ll}1 & 0\end{array}\right)$.

ECOLOGY - It was found in cool southern waters of high salinity for the first time off the Brazilian coast. According to Sewell $(1948$, p. 509) it is a deep-dwelling calanoid recorded from the deeper water of the Mediterranean Sea. Bogorov (1958, p. 152) registers it among the most eurythermal species of the tropical waters which inhabit the "zone of mixing" of boreal and tropical waters in the Northern Pacific and Brodsky (1957, p. 59) lists it among the copepods of the characteristic association of subtropical North Pacific waters.

\section{Fam. Heterorhabdidae}

Heterorhabdus spinifrons (Claus)

SIZE - o $2.01 \mathrm{~mm}$; \% $2.5 \mathrm{~mm}$.

OCCURRENCE - M 407 (3), M 403 (4), M 402 (Pr.), M 395 (8), M 363 (1), M 315 (5), M 247 (3), M 166 (1), M 114 (1), M 100 (1), M 99 (1), M 78 (2), M 75 (4), M 74 (1).

ECOLOGY - It was found in surface off-shore and oceanic waters with more than $35.00 \%$ salinity and temperatures under $23^{\circ} \mathrm{C}$. According to Farran (1929, p. 264) it has a world-wide tropical and temperate distribution. Brodsky (1957, p. 55, 59) mentions it as one of the frequent species of the tropical and subtropical North Pacific. It is recorded here for the first time off Brazil. 


\title{
$-54-$ \\ Heterorhabdus papilliger (Claus)
}

\author{
SIZE - o $1.9 \mathrm{~mm}$; o $1.6-1.7 \mathrm{~mm}$.
}

OCCURRENCE - M 240 (1), M 111 (2), M 78 (4).

ECOLOGY - It was registered off the coast of Brazil (off Bahia and off Cabo São Roque) in oceanic tropical waters by Farran (1929, p. 265). Sewell (1948, p. 209) and Brodsky (1950, p. 353) list it among the deep-dwelling copepods. Farran (1926, p. 283) is of the opinion that it lives usually at $100 \mathrm{~m}$ depth and comes to the surface by night in the temperate Atlantic. This perhaps explains why it was so rarely present in our surface day time samples. The sample M 78 was taken from 108 to $54 \mathrm{~m}$ depth with a closing-net during the night, when the animal had probably migrated to the surface. M 111 was taken during the night and M 240 during the early morning hours. It is here recorded for the first time from Brazilian southern waters. It is among the most frequent species characteristic of subtropical waters in the North Pacific and it is also frequent in the tropical North Pacific (Brodsky 1957, p. 56, 59).

\section{Fam. Augaptilidae}

The following species of this family were represented in small numbers in a few samples: Haloptilus acutifrons (Giesbrecht) in samples M 368 (1 $\%$ of $2.0 \mathrm{~mm}$ ) and in M 409; Haloptilus spiniceps (Giesbrecht) in samples M 368 (Pr.), M 364 (1), M 360 (10), M 240 (1 ㅇ), M 372 (1 o of $4.5 \mathrm{~mm})$ and M 241 (1 $\%$ of $3 \mathrm{~mm}$ ) ; Haloptilus fertilis (Giesbrecht) in sample M 364 (91 $0^{7}$ of $3 \mathrm{~mm}$ ) ; Euaugaptilus hecticus Giesbr. (1 o of $2.8 \mathrm{~mm}$ ) in sample M 365. These species are listed by Sewell (1948, p. 509) as deep-dwelling copepods. The Augaptilid which appeared in a larger number of samples was Haloptilus longicornis (Claus).

\section{Haloptilus longicornis (Claus)}

$$
\text { Size - } 2.1 \mathrm{~mm} \text {. }
$$

OCCURRENCE - M 403 (1), M 369 (2), M 365 (80)*, M 364 (2), M $362(80)^{*}$, M 315 (30), M 314 (1), M 242 (1), M 241 (6), M 240 (2), M 78 (5), M 75 (1), M 74 (1).

ECOLOGY - It was only found in samples from oceanic, high salinity and usually high temperature waters. The samples were all taken from at least $50 \mathrm{~m}$ depth to the surface. The only exceptions are: M 78, in which only deep water layers were 
sampled; M 409, M 75 and M 74, in which the salinity and temperature were low, although the layers sampled were at the surface. They were night samples and the presence of the animal may be due to vertical migration. In the North West Pacific, in subtropical waters, it was found in maximum numbers in the 100-200 m layer (Heinrich 1961, p. 91). It seems to be an indicator of very saline and usually warm oceanic water off the Brazilian coast, though Wilson $(1950$, p. 236) registered it in temperate waters of lower salinity in the Pacific Ocean. Heinrich (1960, p. 36) registered the highest numbers along the $174^{\circ} \mathrm{W}$ meridian between $10^{\circ}$ and $30^{\circ} \mathrm{S}$ and near the Equator on the $154^{\circ} \mathrm{E}$ meridian. In the North Pacific it is listed among the most frequent species of the tropical waters and as one of the frequent species of the subtropical region (Brodsky 1957, p. 55, 59). It is registered here for the first time off the Brazilian coast.

\section{Fam. Candaciidae}

\section{Candacia pachydactyla (Dana)}

$$
\text { Size — ๆ } 2.5 \mathrm{~mm} \text {; ơ } 2.75 \mathrm{~mm} \text {. }
$$

OCCURRENCE - M 510 (20)*, M 497 (4), M 489 (360)*, M 407 (3), M 368 (4), M $364(160)^{*}$, M 315 (1), M 314 (1), M 247 (8), M 246 (6), M 245 (7), M 244 (4), M 243 (1), M 242 (2), M 241 (2), M 240 (4), M 114 (12), M 113 (Pr.), M 111 (4), M 98 (3), M 95 (2), M 39 (3), M 38 (2), M 37 (12), M 36 (6).

Distribution - It was registered by Farran (1929, p. 272) off the Brazilian coast from Rio de Janeiro up to the Equator. The present findings have enlarged its distribution to $31^{\circ} 03^{\prime} \mathrm{S}$ and $04^{\circ} 57.0^{\prime} \mathrm{N}$.

ECOLOGY - This species only occurred in samples taken from very saline (above $35.00 \%$ ) and usually warm waters of the Brazil Current. It did not occur generally in samples taken from cooler water (under $21^{\circ} \mathrm{C}$ ). It was the most numerous Candacia found in our samples, euryhaline, but preferring the higher salinities, and thermophile. Yamazi (1958, p. 151) classifies it as an oceanic, warm water species, which is partially confirmed by our data. It is among the frequent copepods found in the subtropical and tropical regions of the North Pacific (Brodsky 1957, p. 59).

\section{Candacia bispinosa (Claus)}

$$
\text { Size - }+1.75-1.95 \mathrm{~mm} \text {; o } 1.75-1.90 \mathrm{~mm} \text {. }
$$


OCCURRENCE - M 403 (2), M 246 (1), M 243 (5), M 114
(5), M 113 (24).

Remarks - It had been recorded by Farran (1929, p. 272) off the Brazilian coast (Bahia). The present findings enlarge this distribution to $07^{\circ} 28^{\prime} \mathrm{S}$ and $27^{\circ} 15^{\prime} \mathrm{S}$ in oceanic waters of the West South Atlantic. It is among the most frequent Candacia species of the tropical Pacific (Wilson 1950, p. 181; Brodsky 1957, p. 55) in maximum concentration between $30^{\circ}$ and $40^{\circ} \mathrm{S}$ and above $30^{\circ} \mathrm{N}$ along the $174^{\circ} \mathrm{W}$ meridian (Heinrich 1960, p. 36) therefore of subtropical distribution. The same author (Heinrich 1961, p. 90 ) verified its concentration at night in the 50-100 $\mathrm{m}$ and during the day in the 25-50 m layer.

\section{Candacia bipinnata (Giesbrecht)}

SIZE - o $2.2 \mathrm{~mm}$; क $2.3 \mathrm{~mm}$.

OCCURRENCE - M 236 (10), M 173 (1), M 78 (50), M 37 (1).

REMARKS - Already known from Rio de Janeiro. Distribution here enlarged to $25^{\circ} 45^{\prime} \mathrm{S}$. An eurythermic species preferring cooler waters. In tropical waters Brodsky (1957, p. 56) found it present in $25 \%$ of the samples of the East North Pacific, but in subtropical waters it was present in $60 \%$ of the samples from the North Pacific (Brodsky 1957, p. 59) and is recorded also from the Okotsk Sea (op. cit., p. 86-90).

\section{Candacia curta (Dana)}

Size - o $2.3 \mathrm{~mm}$; \& $2.1 \mathrm{~mm}$.

OCCURRENCE - M 407 (2), M 389 (Pr.), M 240 (2), M 78 (4), M 76 (4), M 75 (1), M 74 (15), M 73 (2), M 39 (1), M 38 (23), M 37 (18), M 36 (1), M 35 (12), M 33 (12).

REMARKS - Present only in high salinity (above $35.00 \%$ ) water and temperature lower than $22^{\circ} \mathrm{C}$, with one exception ( $\mathrm{M}$ $240)$. It had already been registered off Rio de Janeiro and up to the Equator, in small numbers. It seems to prefer cooler and very saline waters off our coast, though Farran (1926, p. 272) only registered it in tropical waters. In the Pacific it was among the less frequent Candacia species of tropical and subtropical regions (Wilson 1950, p. 181; Brodsky 1957, p. 55, 59). This speaks in favour of the fact that this animal prefers high salinities. 


\section{$-57-$ \\ Candacia aethiopica (Dana)}

(Fig. 29)

\section{SIZE $-\sigma^{\star} \quad 2.0-2.5 \mathrm{~mm}$; क $2.5-3.0 \mathrm{~mm}$.}

OCCURRENCE - M 497 (Pr.), M 451 (4), M 409 (1), M 407 (8), M 403 (77), M $402(40)^{*}$, M 394 (600)*, M 365 (Pr.), M 364 (Pr.).

ECOLOGY - Registered off the coast of Brazil for the first time in Wilson's (1950, p. 180) paper, it is an eurythermic euryhaline warm water copepod but preferring the lower range of temperatures in these waters (see Farran 1926, p. 272). It is one of the frequent Candacia species in the tropical and temperate Pacific (Brodsky 1957, p. 56). Off Brazil it favours the surface subtropical waters (Fig. 29).

Candacia simplex (Giesbrecht) SIZE - o $2.3 \mathrm{~mm}$; ᄋ $1.7 \mathrm{~mm}$.

OCCURRENCE - M 513 (1), M $510(20)^{*}$, M 365 (Pr.), M $364(80)^{*}$, M 363 (4), M 246 (3), M 244 (1), M 241 (3), M 232 (1), M 100 (1).

REMARKs - Already registered off Rio de Janeiro by Farran (1929, p. 151), its distribution is here enlarged to $03^{\circ} 33^{\prime} \mathrm{S}$ and to $25^{\circ} 00^{\prime} \mathrm{S}$.

It seems to prefer very saline waters (over $36.00 \%$ ) of temperature above $22^{\circ} \mathrm{C}$ off the Brazilian coast. It is the most frequent Candacia in tropical and subtropical waters of the North Pacific (Wilson 1950, p. 182; Brodsky 1957, p. 55, 59).

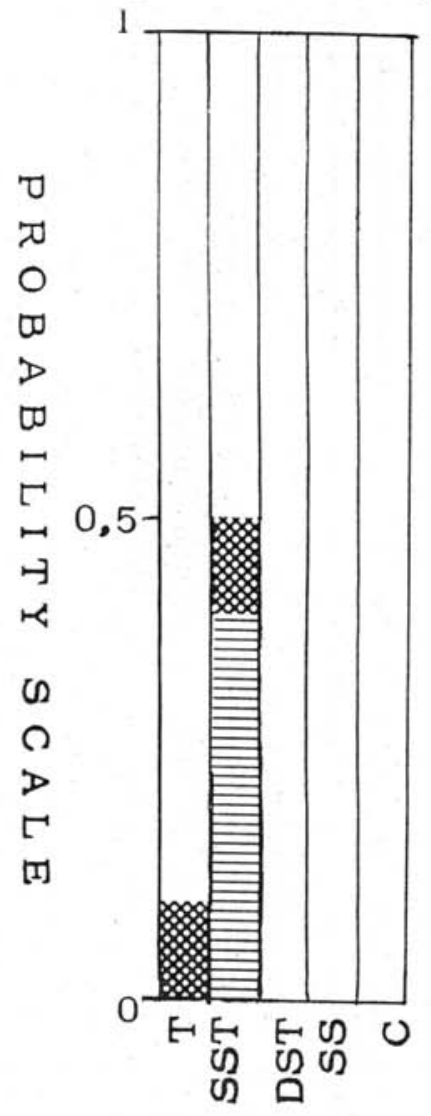

\section{ENVIRONMENTS}

Fig. 29 - Probability of occurrence of Candacia aethiopica in different environments. 


\section{Juvenile Candacia}

OCCURRENCE - M 364 (Pr.), M 246 (3), M 242 (20), M 241 (12), M 240 (6), M 189 (1), M 187 (1), M 163 (2), M 112 (1), M 107 (1), M 100 (1)*, M 99 (6), M 98 (10), M 96 (1), M 75 (14), M 73 (2), M 36 (3).

ECOLOGY - In all these samples the juvenile Candacia always gave preference to layers of high salinity (above $35.00 \%$ ) and under influence of oceanic water, excepting in one sample taken from coastal waters. Candacia seems to be the characteristic genus of shelf or oceanic waters with usually high temperatures and salinities ranging from 33 to $35.5 \%$ (see Wilson 1950, p.

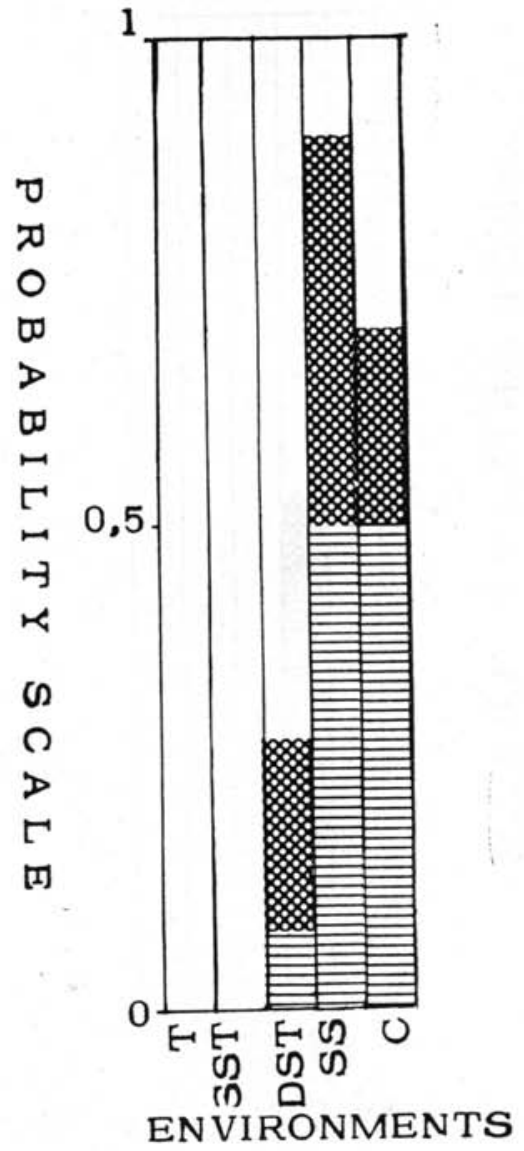

Fig. 30 - Probability of occurrence of Calanopia americana in different environments. 180-184; Brodsky 1957, p. 32) in the Pacific.

\section{Fam. Pontellidae}

Calanopia americana F. Dahl

(Fig. 30)

SIZE $-\sigma^{\star} 1.4 \mathrm{~mm}$; ㅇ $1.5 \mathrm{~mm}$.

OCCURRENCE - M 265 $(270)^{*}$, M 261 (12), M 257 (8), M 188 (2), M 107 (1), M 93 (1), M 76 (2), M 75 (4), M 74 (1), M 73 (8), M 39 (2), M 38 (21), M 36 (5), M 35 (4), M 33 (16), M 32 (2), M 31 (5), M 30 (4), E 164 (7), E 41 (20)*, E 39 $(300)^{*}$, E $32(20) *$, E $30(40) *$, E $28(660)^{*}$, E $24(200)^{*}$, E 16 (36), E 15 (1640)*, E 14 (20)*, E 13 (340)*, E 12 (Pr.), E 9 (1), E 8 (29), E 7 (120)*, E 5 $(560)^{*}, \operatorname{E~} 4(200)^{*}, \operatorname{E~} 3$ (1240)*, $\mathrm{P} 13$ (1), P 12 (2), P 11 (1), P 10 (4), P 9 (11), P 8 (4), $\mathrm{P} 7$ (4), P 5 (8), $\mathrm{P} 4$ (5), $\mathrm{P} 3$ (70), P 2 (11), P 1 (58), II 68 (1), IV 218 (6).

ECOLOGY - This species was described from waters taken off the mouth of the Amazon River (Dahl 1894, p. 12) with sur- 
face salinity $11.8,35.9$ and $36.4 \%$. Off the Brazilian coast it is among the characteristic copepods of shelf waters with salinities 35.00 to $36.00 \%$ and it is found also in costal waters (Fig. 30 ). It is usually not numerous but frequent. According to Sewell $(1948$, p. 452$)$ it appears to be indigenous of the East coast of America. It is euryhaline but with an optimum in the lower salinity of the marine environment.

\section{Labidocera fluviatilis F. Dahl}

(Fig. 31)

Syn. - Labidocera fluviatilis F. Dahl, 1894, p. 12-13, figs. 19-22.

Labidocera brasiliense Farran, 1929, p. 276-277.

Pontella resnautica L. Oliveira, 1946, p. 192-194, figs. 7-13.

Pontellina navalium L. Oliveira, 1947, p. 472-477, fig. 12.

\section{$2.5 \mathrm{~mm}$.}

SIZE - $\odot 2.5 \mathrm{~mm} ; \sigma$

OCCURRENCE - M 394 (120)*, M 283 (3), M 269 (3), M $265(320)^{*}$, M $257(12)$, M 95 (Pr.), M 88 (1), M 73 (1), E 41 (Pr.), E 28 (Pr.), E 3 (20)*, P 13 (8), P 12 (Pr.), P 11 (Pr.), P 10 (Pr.), P 1 (16), II 68 (3), IV 244 (60), III 321 (9), IV 218 (1).

SYSTEMATIC NOTES - L. fluviatilis was firstly described by Dahl (1894, p. 12) from samples of the "Plankton" Expedition taken at the Amazon River's mouth. Farran (1929, p. 276) registered it under the name of $L$. brasiliense from samples of the "Terra Nova" Expedition taken off Rio de Janeiro. The only difference between the animals described by Dahl and by Farran is the proportion between the length of the exopodite and the endopodite of the fifth legs of the female ("three times as

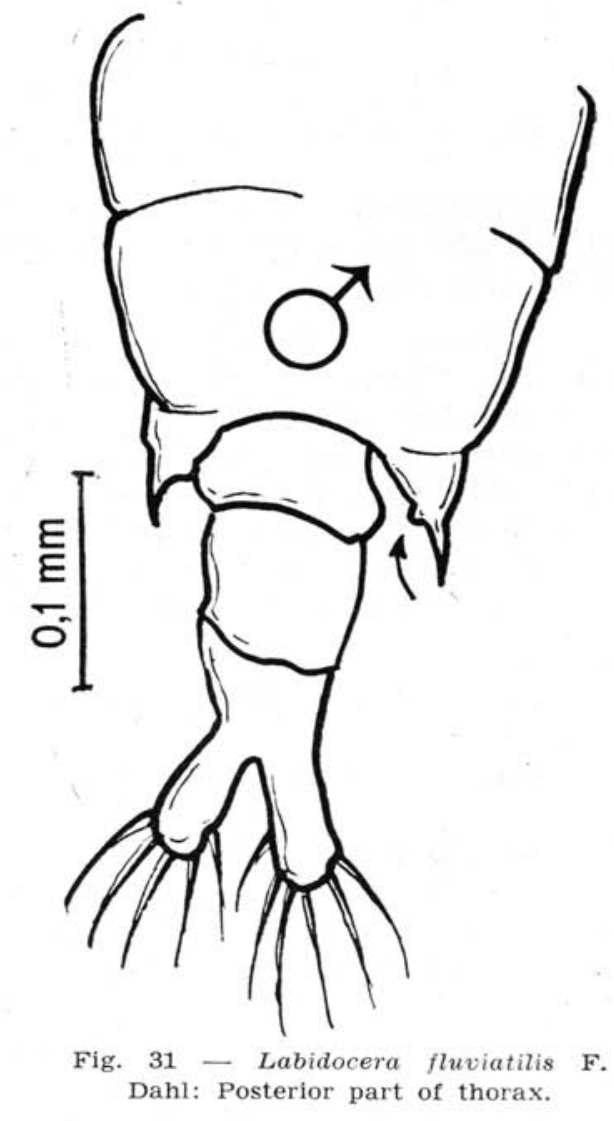


long" as the endopodite in Farran's description; one and a half times as long, in Dahl's). In our samples all the intermediate lengths are found. Dahl did not register a little protuberance on the left point of the last thoracic segment of the adult male. The other acute point of the male's last thoracic joint has no such protuberance (Fig. 31). Oliveira described Pontella resnautica (1946, p. 192-194, figs. 7-13) and Pontellina navalium (1947, p. 472-474) from samples taken off Rio de Janeiro. The descriptions of these animals are identical to that of L. fluviatilis, leaving no doubt as to the synonymy of $P$. resnautica and $\mathrm{P}$. navalium to the latter name.

ECOLOGY - It is a brackish water species, frequently found in fish stomachs (Table XII) and it occurs also in coastal waters. Although euryhaline, its optimum salinity is found in the brackish water environment.

\section{Labidocera acutifrons (Dana)}

$$
\text { SIZE - ᄋ } 4.1 \mathrm{~mm} \text {; ơ } 4.0 \mathrm{~mm} \text {. }
$$

OCCURRENCE - M 407 (3), M 403 (1), M 402 (1), M 394 (3), M 283 (3), M 269 (3), M 238 (2), M 236 (1), M 114 (19), M 95 (1), M 38 (1).

Ecology - Recorded by Farran (1929, p. 274) off Rio de Janeiro. The author only found it in samples taken from waters with salinity above $36.00 \%$ and temperatures under $25^{\circ} \mathrm{C}$ off the southern coast of Brazil. The actual findings confirm Yamazi's (1958, p. 151) statement that it is an oceanic species. In the Pacific it occurs in oceanic waters of lower salinity (see Wilson 1950, p. 242; Brodsky 1957, p. 55, 58). Its environmental optimum is thus the open-sea regardless of salinity.

\section{Pontellopsis brevis (Giesbrecht)}

\section{SIZE $-\sigma^{\star} 1.98 \mathrm{~mm}$.}

OCCURRENCE - V 3 (Pr.), E 164 (1), E 41 (Pr.), E 7 (20)*, P 13 (8), P 12 (Pr.), P 11 (2), P 10 (Pr.), P 1 (1), M 190 (1), M 186 (1), M 107 (1), M 95 (Pr.), M 93 (1), M 74 (4), M 39 (2), M 38 (7), M 37 (1), M 36 (1), M 35 (1).

REMARKS - Farran (1929, p. 280) registered it off Rio de Janeiro. It is frequently found in small numbers in coastal waters and in shelf waters off Brazil. 


\section{Other Pontellopsis}

Pontellopsis villosa Brady was first described from a specimen caught by the "Challenger" Expedition in the middle South Atlantic off Mar del Plata. It appeared in samples M 114 and M 75 . The lengths of the specimens were $\sigma^{7} 1.9 \mathrm{~mm}$, \& $3.0-2.75 \mathrm{~mm}$.

Pontellopsis perspicax (Dana) was described from the middle of the tropical South Atlantic. It was registered in samples M 247 $(1 \% 1.85 \mathrm{~mm}$ ) and M $244(1 \% 2.8 \mathrm{~mm})$ from oceanic, very saline waters (above $36.00 \%$ ).

\section{Pontellina plumata Dana}

$$
\text { Size - o 1.5-1.9 mm; ơ } 1.8 \mathrm{~mm} \text {. }
$$

OCCURRENCE - M 497 (1), M 368 (1), M $364(40)^{*}$, M 363 (1), M 247 (2), M 246 (2), M 245 (1), M 244 (6), M 242 (2), M 114 (1).

ECOLOGY - It seems to prefer very saline (above $36.00 \%$ ) and warm waters (above $22^{\circ} \mathrm{C}$ ) off the Brazilian coast.

\section{Fam. Acartiidae}

Acartia lilljeborghi Giesbrecht

Syn. Acartia fariai Lejeune de Oliveira, 1945

(Fig. 32)

Size - o $1.15-1.2 \mathrm{~mm}$; क $1.4 \mathrm{~mm}$.

OCCURRENCE - M 73 (1), M 38 (4), E 170 (1), E 164 (3), E $39(120)^{*}$, E 28 (180)*, E 11 (Pr.), E 9 (1), E 8 (6), E 7 (20)*, E 2 (1), E 1 (675)*, P 13 (5), P 12 (11), P 11 (20), P 10 (6), P 9 (51), P 8 (37), P 7 (16), P 6 (59), P 5 (12), P 4 (1), P 3 (2), P 2 (7), P 1 (46), II 68 (9), III 322 (4), III 320 (72), IV 244 (4), IV 218 (1).

REMARKs - Already recorded in Brazilian waters by Dahl (1894, p. 2) off the Amazon River's mouth in waters of low salinity $(11.8$ and $12.8 \%$ at the surface and by Carvalho (1952, p. 150) in Santos. Oliveira (1945, p. 459) also registered a juvenile form belonging to this species off Rio de Janeiro as Acartia fariai. 


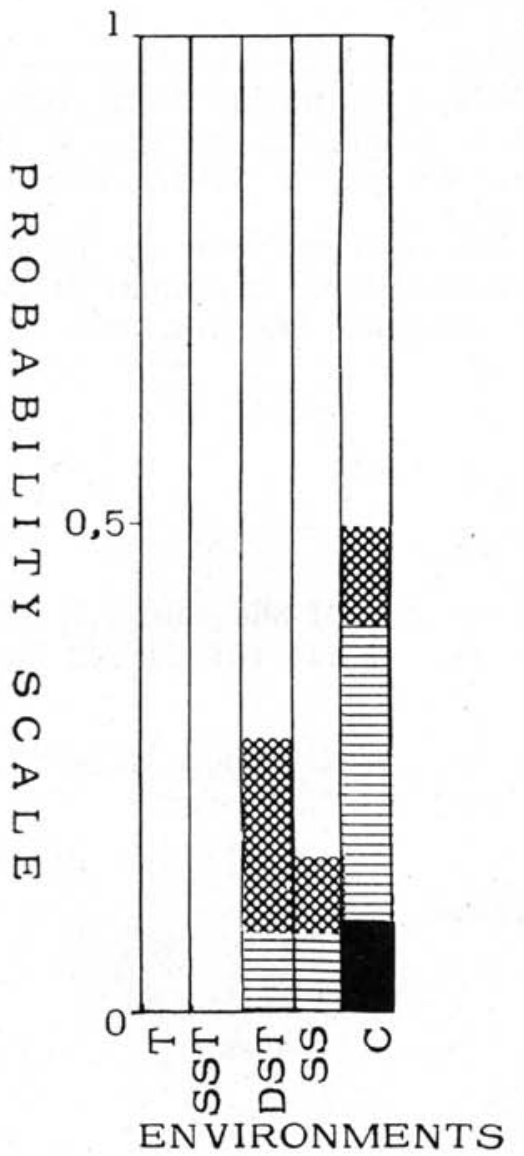

Fig. 32 - Probability of occurrence of Acartia lilljeborghi in different environments.
ECOLOGY - It is distinctly a copepod indicator of coastal waters (Fig. 32). Only few samples which also showed layers of shelf water contained specimens of A. lilljeborghi. All the other samples in which it appeared were taken in purely coastal sea water. It is frequently the dominant copepod in these and therefore also found in the gastric contents of littoral plankton feeders.

Steuer (in Sewell 1948, p. 405) refers to it as an inhabitant of the West Wind Drift which was swept up the east and west coasts of South America by the cold Falkland and Humboldt currents respectively. The known distribution and the present data favour Sewell's (1948, p. 405) doubts about the origin of the species. It is more probably a coastal water stenohaline, but strongly eurythermic species. It was present in the greatest number in inshore waters and waters very near to the coast. It is substituted by $A$. tonsa in the estuarine facies of the Gulf of Mexico (see Fleminger 1959, p. 154) and by a $A$. giesbrechti in the same facies in the mouth of the Amazon River.

\section{Acartia danae Giesbrecht}

(Fig. 33)

\section{SIZE - $-1.25 \mathrm{~mm} ; o^{\star} 1.1 \mathrm{~mm}$.}

OCCURRENCE - M 497 (7), M 409 (Pr.), M 407 (1), M 403 (40), M 402 (40)*, M 400 (Pr.), M 395 (32), M 394 (Pr.), M 364 (1), M 314 (32), M 247 (8), M 242 (1), M 240 (1), M 208 (3), M 189 (2), M 166 (7), M 163 (184), M 162 (615), M 160 (246), M 113 (3), M 111 (1), M 100 (2), M 98 (1), M 88 (2), M 33 (1). 
ECOLOGY AND DISTRIBUTION Already known from Brazilian waters (Farran 1929, p. 282; Carvalho 1944, p. 98-99; 1952, p. 151-152). It occurred in greater numbers in the samples from high salinity waters (above $35.00 \%$ on ) and lower temperatures (approximately $18^{\circ} \mathrm{C}$ ), thus preferring subtropical conditions, confirming Yamazi's (1958, p. 152) classification of the species as temperate. It did not occur in samples of coastal waters with one exception. It is an off-shore species, as stated by Deevey (1952a, p. 90): In the North Pacific it is one of the most abundant species in tropical, subtropical and intermediate waters (Brodsky 1957, p. 55, 59, 62) but was also frequent in the Bering Sea (Wilson 1950, p. 151) though these findings are not confirmed by Brodsky (1957). Heinrich (1961, p. 90) found large numbers of $A$. danae between $25^{\circ}$ and $35^{\circ} \mathrm{N}$ in the West Pacific usually concentrated in the $25-50 \mathrm{~m}$ deep layer or in the $50-100 \mathrm{~m}$ layer, reaching down to $500 \mathrm{~m}$. It is found in still deeper layers (580 to $1,040 \mathrm{~m}$ ) near Japan (Furuhashi 1961, tab. 2) in temperatures about 4 to $5^{\circ} \mathrm{C}$.

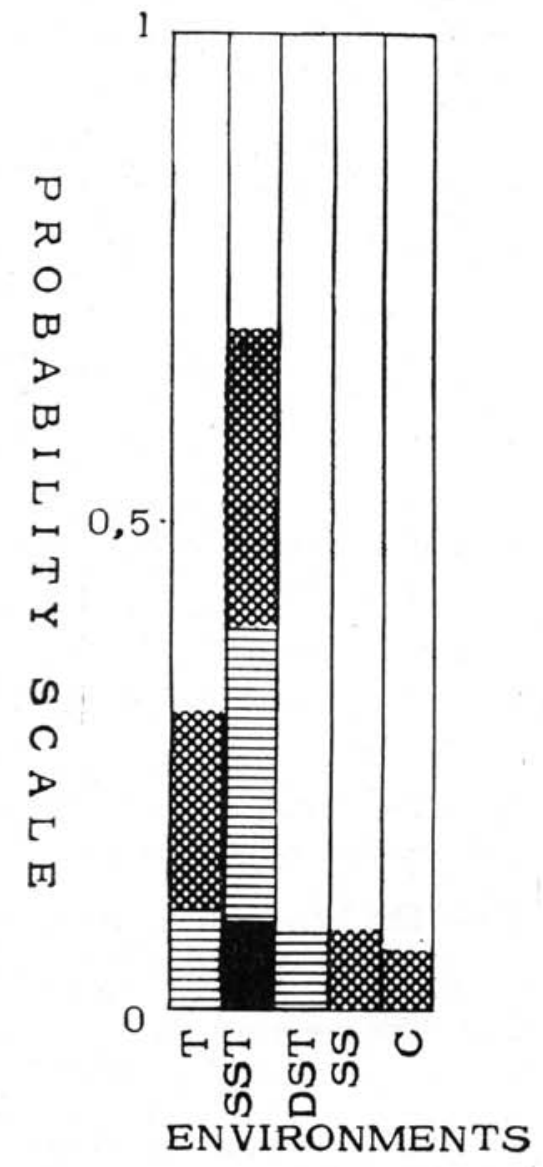

Fig. 33 - Probability of occurrence of Acartia danae in different environments.

\section{Acartia negligens Dana}

Size - $+1.15 \mathrm{~mm}$.

OCCURRENCE - M 489 (60), M 409 (12), M 400 (40), M 394 (600), M 315 (11), M 246 (4), M 243 (5), M 232 (24)*, M 161 (206), M 114 (6), M 97 (6), M 96 (1).

ECOLOGY - Already known from the Brazilian waters. The largest numbers were obtained from subtropical waters. Off South Africa it was abundant in waters of $35.3 \%$ salinity and temperatures around $16.5^{\circ} \mathrm{C}$, thus approximately of the same 
characteristics as the Brazilian environment. It was also present in tropical waters and in one sample of coastal waters. Heinrich (1961, p. 90) found it usually concentrated in the surface, $0-25 \mathrm{~m}$ layer, excepting from 09:45 A.M. to 03:00 P.M. when it was concentrated in the $25-50 \mathrm{~m}$ layer or in the 50-100 m layer. Brodsky (1957, p. 55, 59) also recorded higher percentages of this species in the subtropical region than in the tropical and transition regions of the North West Pacific.

Acartia tonsa var. cryophylla var. nov.

(Fig. 34)

SizE - $+1.25 \mathrm{~mm} ; o^{*} 1.0 \mathrm{~mm}$ (measurements taken from ventral and dorsal view along the midsagittal plane from animals kept in formalin).

DESCRIPTION - It is very much like $A$. tonsa especially the male specimen, but shows slight differences in the following characters :

1 - The first abdominal segment in the male has a few thin spines (Fig. 34d).

2 - The abdomen of the female shows no spinulation along the margin of the abdominal segments (Fig. 34c).

3 - The female's fifth legs have a longer marginal seta on the basal segment than the typical A. tonsa (Fig. 34e).

All other characters are exactly the same as those described for the typical $A$. tonsa (Fig. 34a, b, f).

$$
\text { OCCURRENCE - M } 88 \text { (2), M } 89 \text { (52). }
$$

EcoLogy - Already recorded from Brazil (Rose 1933, p. 276), it was only found in two samples from the south of Brazil, from coastal waters of low salinity $(25.48-33.22 \%$ and relatively low temperatures $\left(14.38-15.40^{\circ} \mathrm{C}\right)$.

Conover (1956, p. 156-233) studied the ecological requirements of A. tonsa in Long Island Sound (N. America). There A. tonsa is also a coastal copepod but indicator of warmer water. Though recorded in temperatures ranging from -0.65 to $32.0^{\circ} \mathrm{C}$ in the North West Atlantic (Deevey 1960, p. 25) in inshore waters, it reaches maximum numbers at the end of August (Deevey 1956, p. 126 and 131) in temperatures above $20^{\circ} \mathrm{C}$ (Riley 1956, p. 17 , 

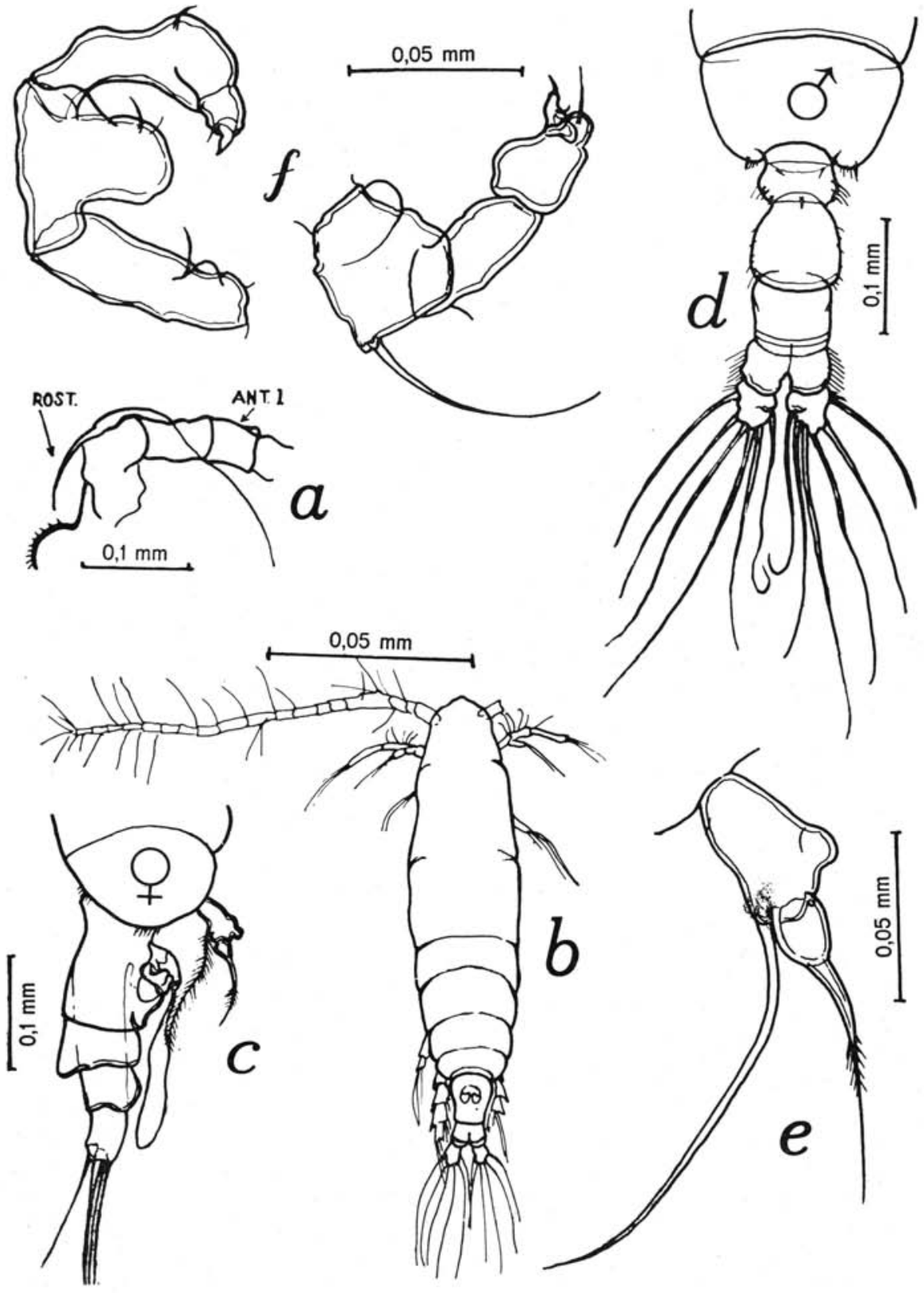

Fig. 34 - Acartia tonsa var. cryophylla nov.: a - Profile of head region, showing rostrum (ROST.) and first antenna (ANT. 1); b - Dorsal view of female; c Lateral view of last thoracic segment and abdomen of female; d - dorsal view of last thoracic segment and abdomen of male; e - fifth leg of female; $\mathrm{f}$ fifth legs of male. 
fig. 1). In this habitat it is frequently dominant in numbers. It was also found to be strongly euryhaline, in salinities from 4.6$35.4 \%$.

Here it is an indicator of cold southern water, therefore the name of the Brazilian new variety, cryophilla.

Conover (1956, p. 218-220) discovered that besides diatoms A. tonsa also feeds on dinoflagellates. In one Brazilian specimen the gastric contents were identified by Teixeira as of a dinoflagellate.

\section{Acartia giesbrechti Dahl}

SIZE - ᄋ $1.1 \mathrm{~mm}$; $\sigma^{\top} 0.9 \mathrm{~mm}$.

OCCURRENCE - M 257 (1435), M 261 (293), M 265 (2670), M 269 (593), M 283 (24).

ECology - Described from plankton samples taken at the mouth of the Tocantins river (Dahl 1894, p. 13) it was one of the dominant copepods in this estuarine facies, in the lower salinities (5.69 to $34.5 \%$ ) where it substitutes the Acartia lilljebor$g h i$ and the A. tonsa from the South of Brazil in the characteristic association for this environment. A good indicator of brackish or inshore waters in the area of the Amazon River's mouth.

\section{Acartia clausi Giesbrecht}

SIZE - ㅇ $1 \mathrm{~mm}$.

OCCURRENCE - E 170 (off Cananéia).

ECOLOGY - It is one of the most common coastal copepods of the North and South cold temperate regions and in the Mediterranean Sea. It was found in the largest numbers by Farran (1929, p. 281) off New Zealand in waters where the temperatures may range from $13^{\circ} \mathrm{C}$ to $21^{\circ} \mathrm{C}$ (Sverdrup et al., 1942, charts II-VI) and the salinities are about 35 or $35.5 \%$ and by Conover (1956, p. 177, 189) in temperatures from $12^{\circ}-18^{\circ} \mathrm{C}$ and in estuarine conditions (Conover 1956, p. 227). Here it occurred at Station III off Cananéia in the winter and is probably a stray from southern cold waters. This should be expected for in the North Atlantic A. clausi is dominant in winter and spring and it is "definitely the more efficient organism at low temperatures" when compared to $A$. tonsa (Conover 1956, p. 221). In the inlet waters of Japan (Yamazi 1956, p. 165) and in the continental bays of the Sea of Japan (Brodsky 1957, p. 73-75) it is among the most frequent species in temperatures between 10 and $23^{\circ} \mathrm{C}$ and salinity between 10.00 and $32.00 \%$. 
Acartia longiremis Lilljeborgh

Size - $1.25 \mathrm{~mm}$; o $1.1 \mathrm{~mm}$.

OCCURRENCE - E 28 (9), E 9 (1), M 403 (40), M 363 (5), M 37 (1), M 36 (2).

ECOLOGY - It is registered for the first time in our coastal and oceanic waters. It was more abundant in a sample from cold southern surface waters $\left(21.09-15.41^{\circ} \mathrm{C}\right.$ temperature and 35.17 $36.88 \%$ salinity). This was to be expected because it is mostly recorded in the northern temperate and boreal waters.

\section{HARPACTICOIDA}

\section{Fam. Ectinosomidae}

\section{The Species of Microsetella}

OCCURRENCE - M 513 (1), M 510 (2), M 497 (34), M 489 (3180)*, M 451 (47), M 407 (9), M 395 (3), M 365 (1680)*, M $364(440)^{*}$, M $363(28)$, M $315(105)$, M $314(24)$, M 208 (6), M 190 (3), M 189 (1), M 188 (1), M 186 (186), M 161 (Pr.), M 98 (1), M 97 (1), E 164 (2), E 41 (Pr.), E 39 (20)*, E 2 (20)*.

REMARKS - Microsetella rosea and Microsetella norvegica have been registered off the coast of Brazil. Many young Microsetella were doubtfully identified first as $M$. norvegica (Boeck) and afterwards as $M$. rosea (Dana). No separation was therefore made between the species in the tables. They were all considered as Microsetella spp. Adult Microsetella rosea and last copepodites of this species have been identified with certainty in the following occurrences. As can be seen from the occurrences above Microsetella generally prefers the open sea. It is known that it occurs in swarms, and it is frequently present in coastal waters and shelf waters as well, off the south of Brazil. Though very small its great numbers are responsible for the fact that it is, when present in the plankton, an important constituent of the food of plankton eaters.

Farran (1929, p. 297) registered the largest number of $M$. rosea in subtropical waters and of $M$. norvegica in the temperate North Atlantic and between $40^{\circ}$ and $50^{\circ} \mathrm{S}$ Lat. in the Pacific where temperatures are cooler. Hensen (1911, p. 281) counted more Microsetella in the colder than in the warm waters. 


\section{Microsetella rosea (Dana)}

SIZE — $\odot 0.60-0.65 \mathrm{~mm}$.

OCCURRENCE - M 497 (2), M 489 (180)*, M 451 (2), M 407 (7), M 403 (480), M 402 (160)*, M 394 (3), M 368 (26), M 365 $(1240)^{*}$, M $364(920)^{*}$, M 363 (28), M 314 (10), M 238 (2), M $232(460)^{*}$, M 208 (9), M 190 (1), M 189 (12), M 187 (3), E 164 (2), E 39 (1), E 32 (1), E 5 (100)*, E 1 (25)*.

ECOLOGY - This small copepod occurs usually in swarms and was found in great numbers in the gastric contents of some plankton-eating fishes (Table XII). It was found in very saline oceanic tropical and subtropical, in deeper and shallow shelf and in coastal waters. It may not have been more frequently found because it escaped from the zooplankton nets usually used (Almeida Prado, 1962) due to its small size. It reached the highest percentages in very saline and warm oceanic waters. The Microsetella were among the chief constituents of the copepod fauna during the "Meteor" Expedition (Hentschel 1933, p. 87), but Hensen (1911, p. 304) observed double as many Microsetella in the northern hemisphere than in the southern during the "Plankton" Expedition. As our samples were not always obtained with the phytoplankton nets, it is not advisable to draw conclusions from them. In the Pacific Heinrich (1961, p. 91) observed the greatest concentrations of $M$. rosea in the surface layers in the North West subtropical region.

\section{Fam. Macrosetellidae}

Macrosetella gracilis (Dana)

(Fig. 35)

\section{SIZE - ○ $1.8 \mathrm{~mm} ; \sigma^{*} 1.25 \mathrm{~mm}$.}

OCCURRENCE - M 513 (60)*, M 497 (2), M 489 (60)* M 409 (2), M 403 (80), M 402 (Pr.), M 395 (3), M 394 (120)*, M 389 $(80)^{*}$, M 368 (Pr.), M $365(200)^{*}$, M $364(9)^{*}$, M $363(6)^{*}$, M 246 (1), M 241 (19), M 240 (94), M 238 (2), M 232 (1), M 208 (14), M 189 (2), M 188 (3), M 166 (4), M 162 (7), M 161 (2), M 160 (7), M 114 (4), M 112 (2), M 100 (1), M 99 (3), M 98 (28), M 97 (9), M 96 (2), M 95 (3), M 93 (1), M 75 (3), M 74 (1), M 39 (5), M 38 (7), M 37 (8), M 36 (3), M 35 (9), E $16(20)$, E $15(40)$, E $13(100)$, E $11(60)$, E 7 (100)*. 
REMARKS - The "Challenger" Expedition recorded this species in the South Atlantic (Brady 1883, p. 23). Davis (1950, p. 101) lists this species as "confined to open waters" on East and West coasts of Florida. Yamazi (1958, p. 153-154) labels it as oceanic, tropical or subtropical in the Pacific. Wheeler (1900, p. 188) lists it among the species of the Gulf Stream. Bogorov (1958, p. 152) places it among the copepods of the zone of mixing $\left(15-18^{\circ} \mathrm{C}\right)$ and of tropical $\left(18-27^{\circ} \mathrm{C}\right)$ oceanic surface waters.

The data obtained from Brazilian waters corroborate Yamazi and Bogorov in what concerns the temperatures of the waters in which it is found (Fig. 35 ), but although oceanic, this species also occurs in coastal waters in large numbers ( $\mathrm{E} 15, \mathrm{E}$ 7). Heinrich (1961, p. 92) found it in very large numbers in the subtropical North West Pacific concentrated in the surface layer or in the $25-50 \mathrm{~m}$ layer in the morning and afternoon. At noon hours it migrates down to 50-100 $\mathrm{m}$ and at dusk and dawn it is concentrated in the 100-200 m layer.

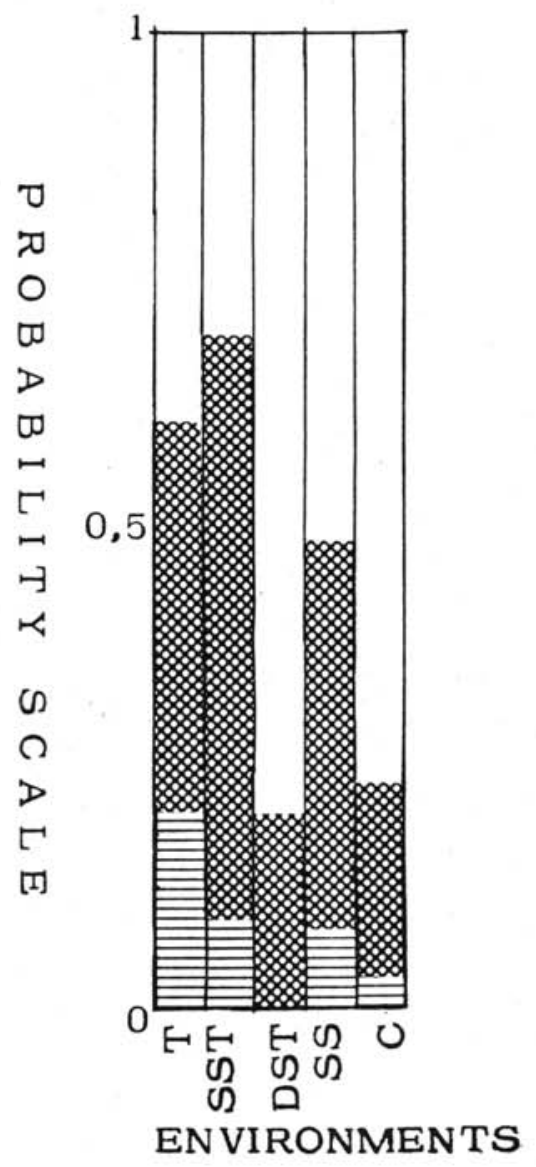

Fig. 35 - Probability of occurrence of Macrosetella gracilis in different environments.

\section{Oculosetella gracilis (Dana)}

Syn. Setella gracilis Sars

\section{SIZE - o $1.15 \mathrm{~mm}$; 우 $1.2 \mathrm{~mm}$.}

OCCURRENCE - M 409 (2), M 407 (Pr.), M 403 (Pr.), M 394 (3), M 364 (Pr.).

REMARKS - It occurred in samples of high salinity and lower temperatures, in subtropical waters. Moore has registered this species off the Bermudas also in the subtropical region (Moore 1949, p. 64). 
Systematic NOTE - But for its vivid coloration and big eye lenses it would easily be mistaken for Macrosetella gracilis. The males recorded here are slightly longer than those figured by Wilson (1932, p. 283).

\section{Miracia efferata Dana}

SIZE $-\subsetneq 1.9 \mathrm{~mm}$.

OCCURRENCE - M $489(120)^{*}$, M 247 (1), M 246 (2).

REMARKS - Registered for the first time off Brazil in oceanic and tropical waters. Farran (1929, p. 298) registered its largest

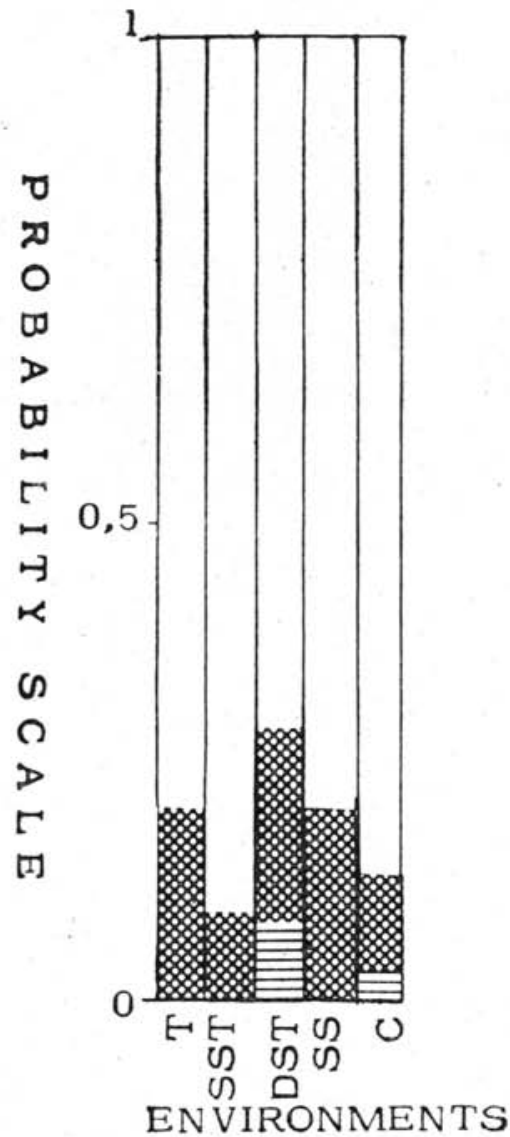

Fig. 36 - Probability of occurrence of Clytemnestra rostrata (Brady) in different environments. numbers in the tropical Atlantic.

\section{Fam. Clytemnestridae}

Clytemnestra scutellata Dana

(Fig. 36)

$$
\text { Size - }+1.2 \mathrm{~mm} \text {. }
$$

OCCURRENCE - M 497 (1), M 403 (1), M 368 (1), M 240 (1), M 232 (4), M 208 (5), M 203 (2), M 190 (1), M 189 (1), M 186 (4), M 98 (1), M 95 (Pr.), M 73 (1), M 38 (2), M 35 (1), P 17 (Pr.), P 15 (Pr.), P 13 (Pr.), P 12 (Pr.), P 11 (Pr.), P 10 (1), P 9 (Pr.), P 8 (Pr.), P 7 (Pr.), P 6 (Pr.), P 5 (Pr.), P 4 (Pr.), P 3 (Pr.), P 2 (Pr.), P 1 (Pr.), E 4 (Pr.), E 5 (1), E 14 (Pr.), E 24 (Pr.), E 32 (Pr.), E 120 (20)*, V 13 (20)*, V $19(60) *$.

REMARKS - It occurred sparingly in samples of nearly all the water masses examined. The highest percentages of this species appeared in coastal waters mixed with shelf waters and 
with salinities from 33.73 to $35.49 \%$ and in deeper shelf waters. Hensen (1911, p. 281) registered the highest percentage of this species in the warm rather than in the cold region during the "Plankton" Expedition.

\section{Fam. Longipediidae}

Longipedia mourei Jakobi

SizE - $90.8 \mathrm{~mm}$.

OCCURRENCE - IV 244 (8), III 320 (1), IV 218 (1).

REMARKs - Studied from the muddy sand in inshore waters of Paranaguá Bay (Jakobi 1954a, p. 210-211) it occurred in three samples in small numbers, taken further north, in Cananéia, from very shallow inshore waters (10 $\mathrm{m}$ deep) of low salinity $(22.37$ to $33.69 \%$ ) and temperatures from 16 to $27.7^{\circ} \mathrm{C}$. It is an euryhaline brackish water benthal copepod according to Remane's (1958, p. 101) classification.

\section{Fam. Tachidiidae}

Euterpina acutifrons

(Fig. 37)

Size - $+0.85 \mathrm{~mm}$.

OCCURRENCE - M 389 (40)*, M 208 (23), M 203 (52), M 190 (52), M 189 (2), M 188 (15), M 186 (3), M 78 (1), M 76 (1), M 73 (1), E $170(60)^{*}, \mathrm{E} 164$ (2), E 41 (60)*, E 39 (1540)*, E 32 (80)*, E 30 (Pr.), E 28 (4060)*, E 24 (140)*, E 16 (2080)*, E 15 (1), E 14 (20)*, E 12 (1720)*, E 10 (24), E 9 (Pr.), E 8 (13), E $4(80)^{*}$, E $2(660)^{*}$, P 13 (18), P 12 (6), P 10 (28), P 9 (6), P 7 (4), P 5 (2), P 4 (3), P 2 (1), IV 244 (26), IV 218 (47), III 322 (4), III 321 (201), III 320 (43), II 68 (153), V 13 (1).

Remarks - Present in the samples from deeper very saline shelf waters. It reached the highest percentages among the copepods of coastal waters. It has a smaller form in waters of low 
salinity. Though present in larger percentage in warm waters during the "Plankton" Expedition (Hensen 1911, p. 281) it showed

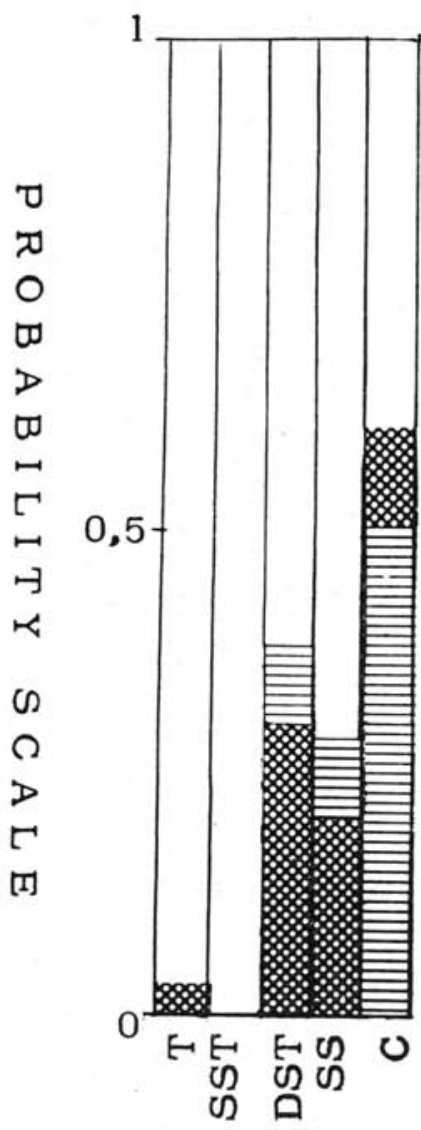

ENVIRONMENTS

Fig. 37 - Probability of occurrence of Euterpina acutifrons in different environments. preference for cooler waters off Brazil (Fig. 37).

\section{Unknown Nauplius}

SIZE $-\subsetneq 1.6 \mathrm{~mm}$.

OCCURRENCE - M 368 (Pr.), M 314 (1), M 240 (2), M 190 (2), M 114 (1), M 113 (1), M 107 (1), M 73 (2), M 39 (1), M 38 (4), M 37 (1), M 36 (5), M 33 (3), E $16(40) *$, E 15 (40)*, E 13 (1), E 12 (1), P 13 (4), P 11 (2), P 10 (3).

REMARKS - It reached the highest percentages relatively to other copepods in shelf waters (of higher salinity and higher temperature). It occurred also rarely in tropical waters and more frequently, but in small numbers, in coastal waters.

\section{Fam. Clausidiidae}

\section{Sapphirella sp.}

Syn. Lanowia prowazeki Lejeune de Oliveira, 1945

Size $-0.9 \mathrm{~mm}$ (young animal).

OCCURRENCE - E 28 (Pr.), E 24 (1), M 208 (10), M 203 (28), III 321 (1), III 322 (1), IV 218 (1), M 246 (1).

REMARKS - "Sapphirella" is probably a young copepod form in the first copepodite stage (Sewell 1928, p. 802-803). It has been registered off Rio de Janeiro under the name Lanowia prowazeki (Oliveira 1945, p. 465-468, est. 4, 7). It occurred in 
southern coastal waters and in one sample of tropical water off the coast of Pernambuco. It fits the general description of "Sapphirella" tropica (Farran 1936, p. 139) and of "Sapphirella" indica (Sewell 1928, p. 800-803).

\section{Other Harpacticoida}

In some samples from coastal waters and also from inshore waters some unidentified benthal harpacticoida were present.

\section{CYCLOPOIDA}

\section{Fam. Oithonidae}

\section{Genus OITHONA Baird}

The small size and the delicacy of the animals which belong to this genus make it difficult to identify them with precision when in great numbers.

Reviewed in 1917 by Rosendorn (1917, p. 3-58), the following species of this genus were assigned to Brazilian waters: $O$. plumifera, O. setigera $(=O$. challengeri ? Brady $=O$. tropica Wolf), O. similis Claus; $O$. minuta Scott ( $=O$ hebes Wolf) and O. simplex Farran (at the mouth of the Amazon River); O. amazonica Burkhardt from fresh water in the Aramá Grande River on the Marajó Island, and at the Amazon River's mouth.

$O$. nana and $O$. brevicornis were recorded in the Congo River's mouth; O. plumifera had its greatest relative numbers in the Guinea Gulf. O. setigera, O. robusta, O. tenuis, O. fallax and $O$. pseudofrigida had their maxima in the Indian Ocean.

O. atlantica, O. frigida, O. similis had their maxima in the cold southern and northern waters (West Wind Drift and Arctic). The remaining species apparently are typical of the tropical and subtropical regions.

$O$. plumifera seems to be the most widespread copepod in the Brazilian waters. O. nana is the next in frequency. $O$. setigera occurred in samples of very saline but usually cooler waters of the shelf or subtropical waters. O. oculata was registered for the first time off Brazil in very saline and warm waters. $O$. ovalis, $O$. brevicornis, $O$. amazonica occurred in samples of coastal or almost brackish waters in small numbers or in swarms. All were registered chiefly off the southern coast of Brazil.

O. robusta was registered in samples M 240 (4), and M 315 (13), in very saline and warm waters. 
The cold water species, $O$. atlantica and $O$. frigida were not yet registered here and neither were $O$. tenuis, $O$. fallax and $O$. pseudofrigida, which seem to be restricted to the African region of the Atlantic and to the West Wind Drift. In many samples, young unidentifiable Oithona were found: M 244 (47), M 363 (28), M 395 (43), M 400 (110), M 513 (46).

\section{Oithona plumifera Baird}

(Fig. 38)

\section{SIZE - $1.1-1.8-1.9 \mathrm{~mm} ; \sigma^{*} 1.2 \mathrm{~mm}$.}

OCCURRENCE - M 510 (1020), M 497 (277), M 489 (27), M 451 (980), M 409 (15), M 407 (3), M $402(240)^{*}$, M 394 (24), M $389(560)^{*}$, M 368 (7), M $364(2240)^{*}$, M $365(29)$ *, M 315 (209), M 314 (107), M 283 (12), M 247 (289), M 246 (179), M 245 (33), M 244 (60), M 243 (45), M 242 (34), M 241 (110), M 240 (140), M 236 (1), M $232(80)^{*}$, M 208 (17), M 190 (13), M 189 (102), M 187 (61), M 173 (1), M 163 (90), M 161 (3), M 114 (34), M 113 (27), M 112 (5), M 111 (1), M 107 (Pr.), M 100 (2), M 99 (90), M 98 (199), M 97 (10), M 96 (6), M 88 (3), M 76 (18), M 75 (30), M 74 (22), M 73 (8), M 39 (11), M 38 (28), M 37 (70), M 36 (113), M 35 (21), M 33 (19), M 32 (4), M 31 (2), M 30 (1), P 17 (Pr.), M 15 (Pr.), P 14 (Pr.), P 13 (3), P 12 (17), P 11 (38), P 10 (4), P 9 (41), P 8 (7), P 7 (47), P 6 (42), P 5 (8), P 4 (27), P 3 (10), P 2 (37), P 1 (15), E 170 (Pr.), E 164 (3), E 41 (280)*, E 39 (40) *, E 24 (Pr.), E 16 (400)*, E $15(320)^{*}$, E 12 (Pr.), E 11 $(360)^{*}$, E $10(880) *$, E 9 (6), E 8 (2), E 7 (260)*, E 4 (20)*,

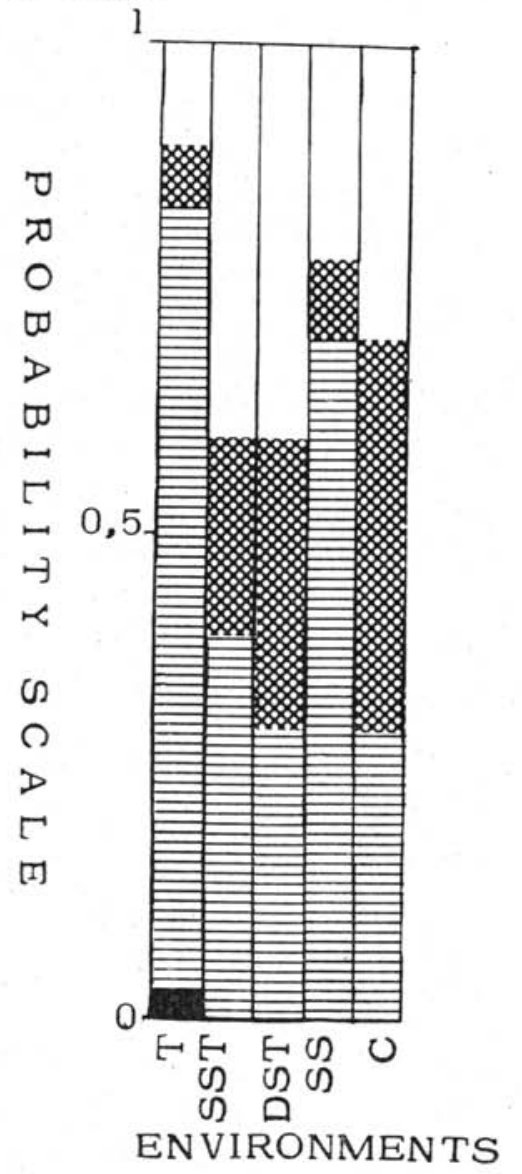

Fig. 38 - Probability of occurrence of Oithona plumifera in different environments. 
E 3 (140)*, E 2 (Pr.), E 1 (75)*, V 19 (1140)*, V 13 (320)*, V 2 (Pr.), V 1 (540), III 320 (1), II 68 (1), IV 244 (1).

REMARKS - The absence of this species in some samples may be due to selectivity of the net used. Zooplankton nets usually do not catch the copepodites for they escape through the larger meshes (Almeida Prado, 1962).

It is one of the most common copepods. It is cosmopolitan and occurs in coastal and in oceanic waters. It was not usually present in the samples from brackish water and its largest numbers and frequencies occurred in oceanic and shelf waters with higher salinity (Fig. 38). Farran (1929, p. 282) registered the largest numbers in the tropical Atlantic.

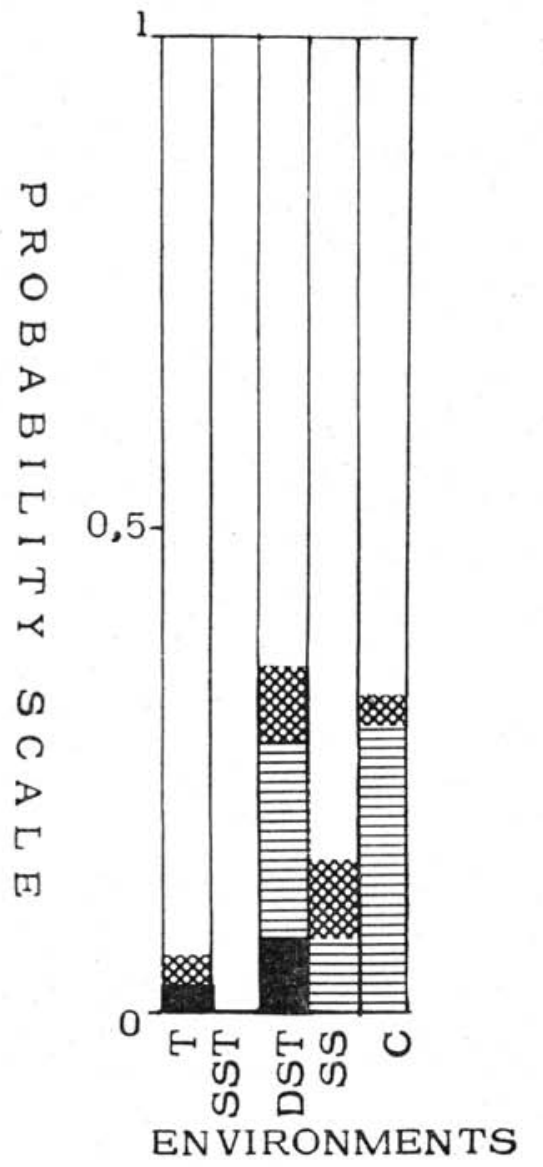

Fig. 39 - Probability of occurrence of Oithona nana in different environments.

\section{Oithona nana Giesbrecht}

(Fig. 39)

SIZE - $0.55-0.6 \mathrm{~mm}$; $\sigma^{*}$ $0.4 \mathrm{~mm}$.

OCCURRENCE - M 510 (Pr.), M 395 (Pr.), M 236 (2004), M 208 (19), M 190 (Pr.), M 189 (531), M 188 (1), M 187 (11), M 186 (5), M 163 (Pr.), E 41 (Pr.), E 39 (980)*, E 32 (120)*, E 30 (Pr.), E 28 (Pr.), E $24(280)^{*}$, E $14(320) *$, E 13 (500)*, E 12 (1280)*, E 10 (880)*, E 8 (2), E 5 (1960)*, E $4(1980)^{*}, \operatorname{E~} 2(12,920)^{*}$, P 2 (496), P 9 (7), P 10 (7), P 11 (1), P 12 (2), P 13 (3), III 321 (151).

REMARKs - Labelled as "neritic or littoral, south-temperate" by Yamazi (1958, p. 153) for Japanese waters, it seems to prefer deeper shelf and coastal waters here also (Fig. 39). It sometimes forms very large patches. As the nets generally used for sampling were zooplankton nets its absence in many samples may be due to the mesh size. 


\section{Oithona setigera (Dana)}

(Fig. 40)

\section{SIZE - $+1.80-2.0 \mathrm{~mm}$; ơ $0.93 \mathrm{~mm}$.}

OCCURRENCE - M 403 (280), M 400 (Pr.), M 395 (Pr.), M 394 (Pr.), M $389(40)$, M $365(80)^{*}$, M $364(40)^{*}$, M 315 (57), M 314 (5), M 208 (2), M 190 (23), M 187 (3), M 162 (9), M 160 (16), M 113 (3), M 111 (3), M 78 (59), M 75 (11), M 74 (5), M 73 (4), M 36 (6), M 35 (2), V 19 (30)*.

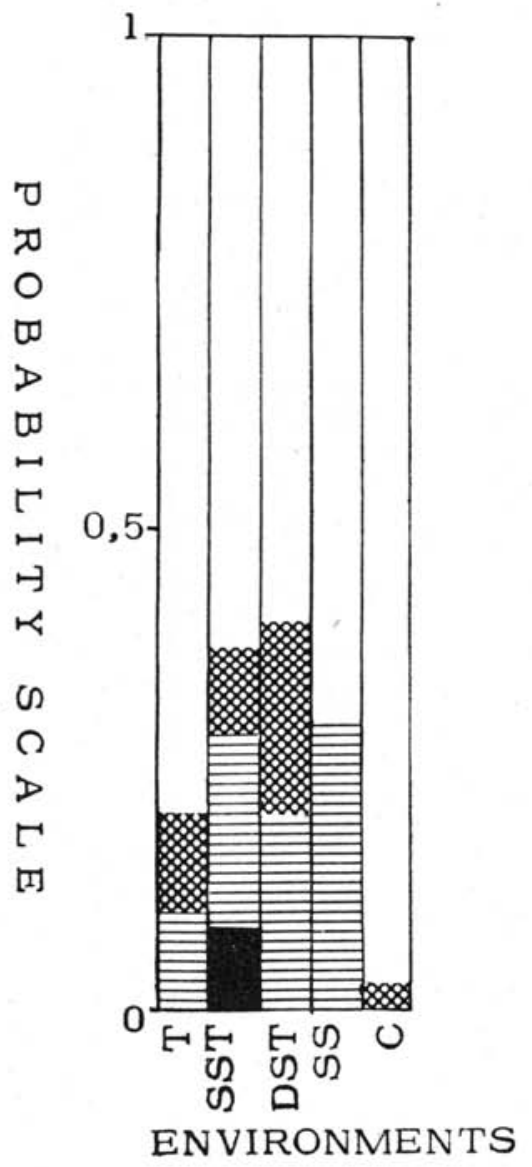

Fig. 40 - Probability of occurrence of Oithona setigera in different environments.

REMARKS - Dominant in surface subtropical waters. It occurred more frequently in samples taken from very saline deeper and surface shelf waters, in salinity above $35.00 \%$. Farran (1929, p. 283) found the largest numbers of this species in the tropical Atlantic.

\section{Oithona oculata Farran}

Size $-0.6 \mathrm{~mm}$ (juvenile).

OCCURRENCE - M 513 (Pr.).

REMARKs - Discovered in Samoan waters which belong to the tropical waters of the Pacific, it was registered in the warmest waters off Brazil in the South Equatorial Current. It is easily recognized by the eye lenses.

\section{Oithona ovalis Herbst}

SIZE — क $0.55-0.6 \mathrm{~mm}$; क 0.50-0.55 mm.

OCCURRENCE - E 41 (300), E 28 (1140), E 8 (27), E 12 (Pr.), E 39 (Pr.), E 2 (Pr.), II 68 (2), III 320 (54), III 322 (161), IV 218 (91), IV 244 (8), P 13 (3). 
ECOLOGY - Discovered in the brackish waters of the mangrove region of Southern Brazil (Herbst 1955, p. 215) it occurred in several samples taken from coastal waters apparently as a stray visitor from the mangrove region nearby and in several samples from the inshore waters near the mangrove region, where it was sometimes the dominant copepod (Tundisi)*.

Systematic NOTE - It is very easily mistaken for Oithona nana, the difference being the pointed cephalon of $O$. ovalis and the flat cephalon, the mandibulae and maxillae of $O$. nana. It is also difficult to distinguish it from $O$. minuta, from which it differs only in the details of the mandibula and maxila (see Rosendorn 1917, p. 36).

\section{Oithona similis Claus}

\section{OCCURRENCE - M 166 (1 juv.).}

REMARKS - It was found in the cold southern waters off Brazil and in a sample of subtropical water off South Africa (Table XVI). This should be expected for in the North Atlantic it is a cold water form (Deevey 1960, p. 47).

\section{Fam. Oncaeidae}

Though sometimes in very large numbers, the representatives of this family do not generally influence the volume of plankton samples strikingly, because of their usually small size.

\section{Lubbockia squillimana Claus}

\section{SIZE $-\sigma^{*} 2.0 \mathrm{~mm}$.}

OCCURRENCE - M 409 (Pr.), M 407 (1), M 403 (4), M 402 (40)*, M 368 (Pr.), M 365 (200)*, M 315 (1), M 314 (1), M 241 (1), M 240 (3), M 113 (1), M 111 (1), M 78 (1), M 76 (2), M 75 (1), V 13 (1).

REMARKS - It is another usually scarce copepod, entirely absent from all the coastal water samples examined. It occurred in three samples of the deeper saline layers and in several samples of very saline water (above $36 \%$ ) and of temperatures ranging from 14.3 to $29.27^{\circ} \mathrm{C}$. It is registered off Brazil for the first time. Heinrich (1961, p. 91) found it usually concentrated in the 25-50 m layer in the subtropical North West Pacific region.

* Tundisi, J. - São Paulo, Inst. Ocean. Personal communication. 
Oncaea media Giesbrecht

(Fig. 41)

\section{SIZE - $+0.85-0.95 \mathrm{~mm} ; \sigma^{\star} \quad 0.7 \mathrm{~mm}$.}

OCCURRENCE - M $513(360)$ *, M $510(400)^{*}$, M 451 (120)*, M $497(123)$, M $489(3600)^{*}$, M 409 (16), M 407 (36), M 402 $(800)^{*}$, M 400 (12), M 395 (97), M $394(600)^{*}$, M 389 (4960)*, M 368 (67), M $365(560)^{*}$, M 364 (3320)*, M 315 (188), M 314 (2), M 247 (84), M 246 (37), M 245 (1), M 244 (144), M 243 (6), M 242 (5), M 241 (18), M 240 (79), M 236 (16), M 238 (34), M $232(360)^{*}$, M 208 (224), M 203 (80), M 190 (5000), M 189 (32), M 188 (21), M 187 (131), M 186 (31), M 173 (1),

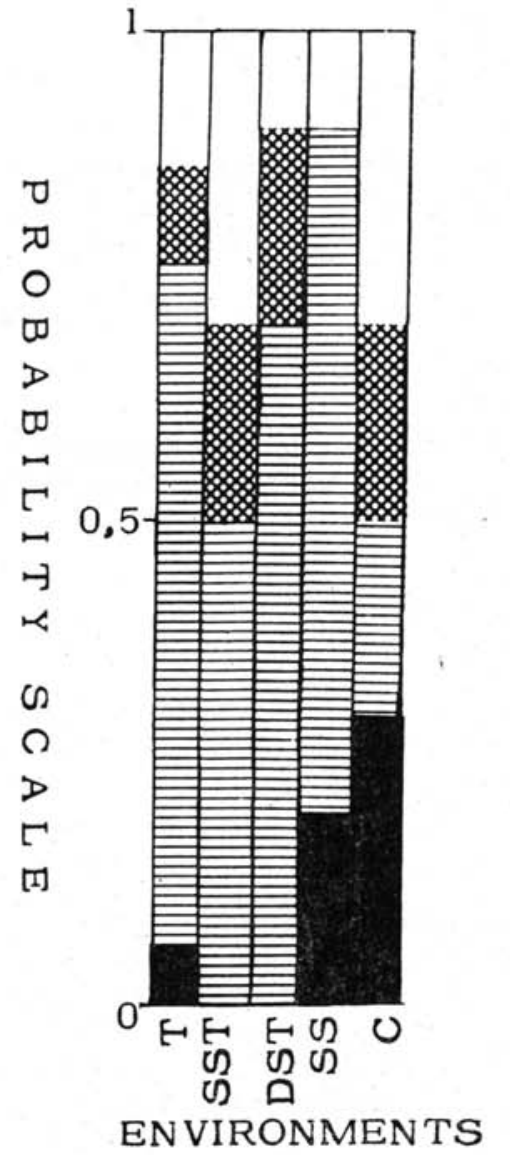

Fig. 41 - Probability of occurrence of Oncaea media in different environments.
M 166 (25), M 162 (16), M 160 (1), M 114 (55), M 113 (24), M 112 (1), M 111 (17), M 99 (122), M 98 (177), M 97 (122), M 96 (93), M 95 (57), M 93 (7), M 89 (1), M 88 (2), M 78 (49), M 76 (55), M 75 (34), M 74 (21), M 73 (3), M 39 (15), M 38 (43), M 37 (204), M 35 (46), M 33 (125), M 32 (5), M 31 (2), M 30 (5), E 170 (3), E 164 (4), E $41(500)^{*}$, E $39(4400) *$, E $32(140)^{*}$, E $30(360)^{*}$, E 28 $(5780)^{*}$, E $\left.24(4820)^{*}\right)$, E 16 $(57,100)^{*}, \quad$ E 15 (1), E 14 $(8420)^{*}, \quad$ E $13 \quad(20) *$, E 12 $(7930)^{*}$, E $10(1460)^{*}$, E 8 (1023), E 5 (3520)*, E 4 $(40,220)^{*}$, E $2(24,440)^{*}$, P 10 (44), P 9 (16), P 1 (1), V 1 (20), V 19 (270)*, II 68 (255), IV 244 (2), III 321 (1).

Remarks - The most common Oncaea in our collections. A smaller form (yellow) occurs in coastal waters and a larger (blueish or lilac when kept in formalin) in the more saline waters. It is frequently the dominant plankter in number of specimens present in the sample. It is small but since it is often present 
in large swarms it occurs frequently in the gastric contents of plankton-feeding fish. It was found in the largest numbers in coastal and shelf waters. In coastal waters its number diminishes considerably as the salinity decreases. Farran (1929, p. 285) found the largest numbers of this species between $30^{\circ}$ and $40^{\circ}$ Lat. $\mathrm{S}$ in temperatures which vary between $15^{\circ}$ and $21^{\circ} \mathrm{C}$ and in salinities around $35.00 \%$.

\section{Oncaea venusta Philippi}

(Fig. 42)

$$
\text { SIZE — }+1.01-1.40 \mathrm{~mm} ; \sigma^{7} 0.95 \mathrm{~mm} \text {. }
$$

OCCURRENCE - M 513 (1), M 497 (15), M 489 (900)*, M 409 (13), M $407(105)$, M 403 (150), M 402 (320), M 400 (1), M $395(22)$, M $394(640)^{*}$, M 389 (120)*, M 368 (Pr.), M 365 (Pr.), M $364(400) *$, M 363 (31), M 315 (35), M 314 (27), M 247 (20), M 246 (39), M 243 (12), M 242 (3), M 232 (280), M 189 (21), M 187 (17), M 173 (1), M 166 (1), M 163 (3), M 161 (172), M 160 (21), M 114 (14), M 113 (3), M 112 (37), M 111 (50), M 107 (Pr.), M 100 (9), M 96 (1), M 78 (10), M 75 (5), M 74 (7), M 39 (4), M 37 (5), M 36 (11), M 35 (8), M 33 (1), M 31 (1), E 4 (20)*.

REMARKS - In larger numbers in oceanic tropical and subtropical surface waters and usually in smaller numbers or absent in coastal and shelf waters. A good indicator because of its colour and large numbers.

Oncaea mediterranea Claus?

$$
\text { Size }-\sigma^{\pi} 0.8 \mathrm{~mm} \text {. }
$$

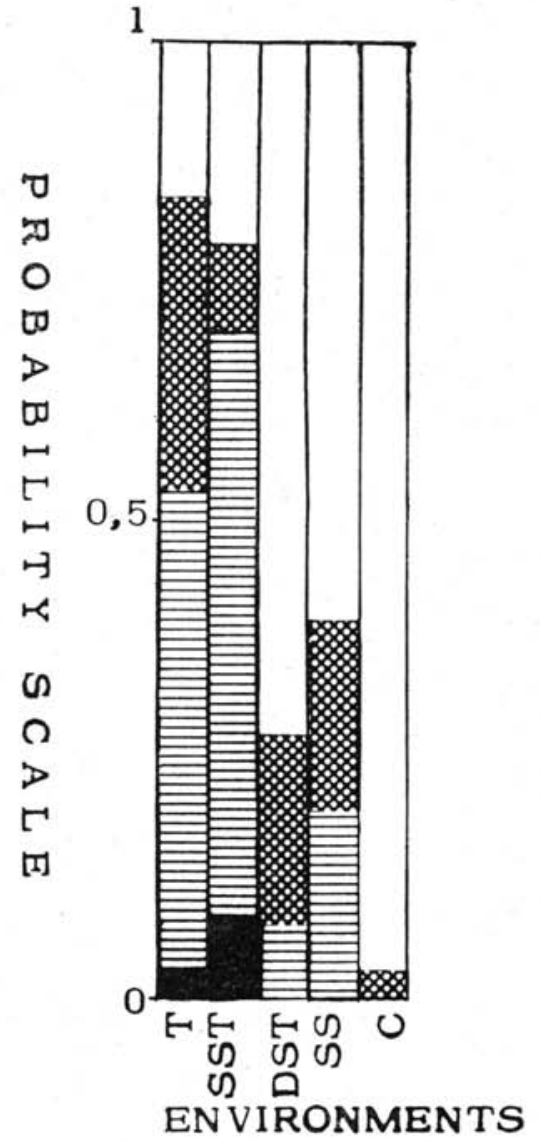

Fig. 42 - Probability of occurrence of Oncaea venusta in different environments. 
OCCURRENCE - M 403 (417), M $402(840) *$, M 400 (24), M $394(40)^{*}$, M $389(120)^{*}$, M $364(440)^{*}$, M $315(100)$, M 113 (2), M 78 (2), M 36 (106), E 30 (360)*, E 28 (5760)*, M 451 (40), M 497 (12), M $489(1500)^{*}$, E 16 (100), E 12 (7930)*, E 8 (109), E $5(20) *$, V 13 (20).

REMARKs - An animal was usually found in coastal waters with the characteristics of $O$. mediterranea but it was never found in the adult stage, therefore it may be a juvenile form of some other Oncaea. O. mediterranea had not been recorded in Brazilian waters. The largest number of $O$. mediterranea was found in very saline, cold, southern, surface waters. It is eurythermic with its optimum environment in the temperate waters of the world (Mediterranean Sea, off New Zealand - Farran 1929, p. 285). Vervoort (1957, p. 147) registered it in deep layers off the Antarctic in $12.6^{\circ} \mathrm{C}$ down to $7.9^{\circ} \mathrm{C}$.

\section{Oncaea conifera Giesbrecht}

$$
\text { Size — o 1.05-1.3 mm; ơ 0.7-1.0 mm. }
$$

OCCURRENCE - M 407 (20), M 403 (120), M 395 (2), M 389 (80)*, M 187 (4), M 111 (3), M 78 (17), M 76 (5), M 75 (10), M 74 (5), M 38 (4), M 36 (1), M 30 (1), E $2(45,000) *$, V 1 (20), V $13(20)$.

REMARKS - Not previously recorded in Brazilian waters, this animal was frequently found in small numbers in coastal and in water masses where the temperature was below $22^{\circ} \mathrm{C}$ approximately. It is a species which prefers temperate waters (Farran 1929, p. 286; Vervoort 1957, p. 146-147). It was registered in deep layers (down to $750 \mathrm{~m}$ ) in temperatures around 8 and $7^{\circ} \mathrm{C}$ and salinities about $34.00 \%$ off the Antarctic Continent (Vervoort 1957, p. 147 and Johnston, 1937).

\section{Oncaea subtilis Giesbrecht}

SIZE - o $0.4 \mathrm{~mm}$; $+0.5 \mathrm{~mm}$.

OCCURRENCE - M 395 (2), M 389 (80)*, M 368 (Pr.), M 365 (5), M 363 (174), M 315 (64), M 236 (144), M 189 (89), M 161 (1), M 95 (5), M 76 (1), E 15 (1), E 10 (1460)*, E 5 (18,680)*, E $4(3700)^{*}$, E $3(40)^{*}$, E $2(29,820)^{*}$.

Remarks - Not yet found in the South Atlantic. It occurs in swarms chiefly in deep coastal waters and in shelf waters. 
In more saline waters it was registered in lower temperatures $\left(22^{\circ} \mathrm{C}\right.$ or less). According to Farran (1929, p. 286) it occurred in largest numbers in waters with low temperatures (76-78 $\mathrm{S}$ Lat.), thus suggesting that this species is very eurythermic, but strongly cryophile.

Oncaea minuta Giesbrecht

SizE - $+4.5 \mathrm{~mm}$.

513 (?).

OCCURRENCE - M 314 (8), M 365 (640)*, M 368 (?), M

REMARKS - Registered with certainty only in two samples, it is one of the species which may pass through the larger meshed plankton nets because of its small size.

\section{Fam. Corycaeidae}

Systematically and zoogeographically this is perhaps the best studied family of marine cyclopoid copepoda in the South Atlantic.

Dahl (1912, p. 129) classifies them as coastal subtropical and tropical for the Atlantic. When compared with Klevenhusen's (1933, p. 97) conclusions for the South Atlantic, we find that both authors agree for most Corycaeus species, classifying them as follows:

\begin{tabular}{lll}
\multicolumn{1}{c}{ COASTAL } & \multicolumn{1}{c}{ SUBTROPICAL } & \multicolumn{1}{c}{ TROPICAL } \\
C. africanus & C. clausi & C. speciosus \\
C. amazonicus & C. flaccus & C. furcifer \\
C. giesbrechti & C. typicus & C. latus \\
& C. limbatus & C. gracilis \\
& C. lautus & \\
& C. furcatus & \\
& C. rostratus &
\end{tabular}

The present study reveals why Klevenhusen and Dahl do not agree sometimes as to whether a copepod is coastal or oceanic. Preferentially coastal forms such as C. giesbrechti may occur in oceanic waters in small numbers and others, oceanic like $C$. latus, may occur in coastal waters too. Of the Corycaeidae registered here by Klevenhusen (1933) only Ditrichocorycaeus minimus was not found. C. africanus was registered here for the first time. 


\section{Genus CORYCAEUS Dana}

\section{Onychocorycaeus giesbrechti Dahl}

(Fig. 43)

\section{SIZE - o $0.8-1.1 \mathrm{~mm}$; क $1.0 \mathrm{~mm}$.}

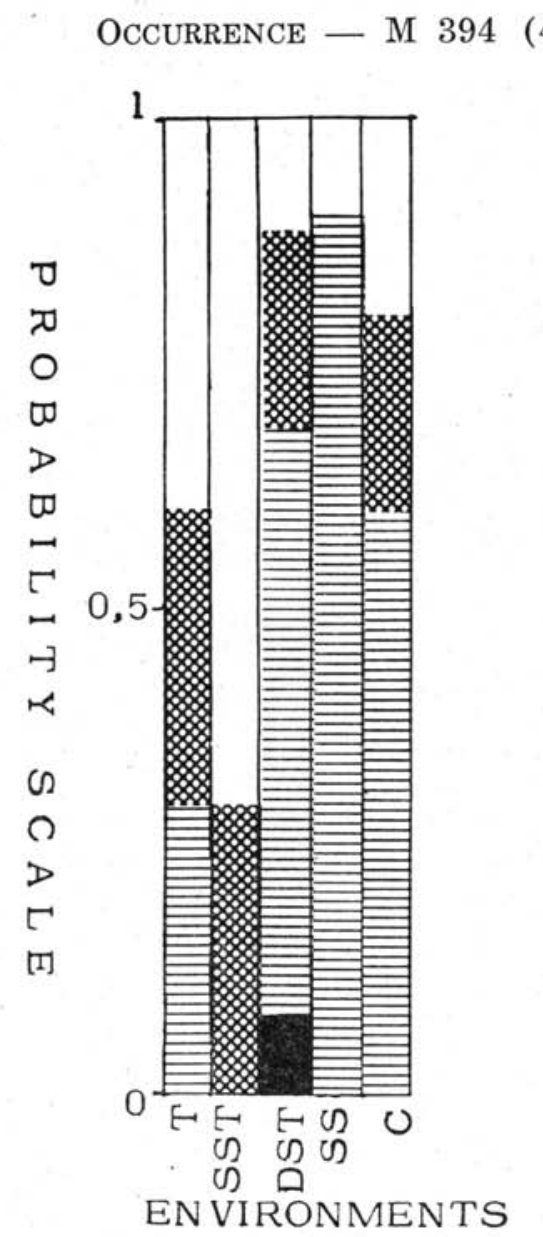

Fig. 43 - Probability of occurrence of Corycaeus giesbrechti in different environments.
* $389(880)^{*}$, M $365(160)$ M $364(40)^{*}$, M $315(3)$, M 283 (37), M $265(1140) *$, M 261 (1), M 257 (9), M 243 (5), M 242 (1), M 241 (4), M 238 (2), M 236 (21), M 232 (40), M 208 (79), M 203 (31), M 190 (140), M 189 (9), M 188 (46), M 187 (70), M 186 (34), M 173 (51), M 166 (2), M 162 (1), M 112 (3), M 111 (16), M 107 (8), M 100 (4), M 99 (66), M 98 (58), M 97 (1), M 96 (6), M 95 (Pr.), M 93 (39), M 88 (1), M 78 (65), M 76 (1), M 75 (127), M 74 (137), M 73 (43), M 39 (2), M 38 (43), M 37 (4), M 36 (21), M 35 (176), M 32 (7), M 31 (12), M 30 (7), E 170 (140)*, E 164 (30), E 41 (Pr.), E 39 $(320)^{*}$, E $32(40)^{*}$, E 30 (1), E $28(380) *$, E $24(100) *$, E 16 $(1060) *$, E 15 (2120)*, E 14 $(200) *, \quad$ E $13 \quad(1620) *$, E 12 (1380)*, E $11(2920) *$, E 10 (240)*, E 9 (29), E 8 (11), E 7 $(700)$ *, E $4(340)^{*}$, E 3 (6520)*, E $2(400)^{*}$, E 1 (1650)*, P 13 (22), P 12 (37), P 11 (18), P 10 (29), P 9 (17), P 8 (4), P 7 (21), P 6 (16), P 5 (3), P 4 (21), P 3 (10), P 2 (15), P 1 (8), III 320 (5), II 68 (41), IV 244 (27), III $321 \quad(3), \cdot V \quad 1$ (800), V 2 (Pr.), V 3 (Pr.), V $13(160)^{*}$, V 19 (1710)*

ECOLOGY - C. giesbrechti is usually present and may occur in dominant or subdominant numbers in shelf and coastal waters (Fig. 43). It also occurs in the other waters, but in small per- 
centages relatively to other copepods. In samples from water layers of very low salinity, under $20 \%$, off the Amazon River's mouth and off Cananéia, the animal did not occur. It did not occur or appeared in very small numbers in two samples of coastal waters under $16^{\circ} \mathrm{C}$ of temperature taken from the surface. It seems to prefer waters of salinities ranging from more or less 30.00 to $35.00 \%$ with temperatures above $15.4^{\circ} \mathrm{C}$. This is corroborated by Dahl's (1894, p. 12) and Farran's (1929, p. 295) findings. It is an eurythermic thermophile, preferring shelf and coastal waters.

\section{Ditrichocorycaeus amazonicus Dahl}

0.82 SIZE - $+0.9 \mathrm{~mm} ; \sigma^{7}$ OCCURRENCE - M 365 (Pr.), M 283 (42), M 265 (2370)*, M 208 (1), M 203 (3), M 173 (1), M 78 (11), M 76 (60), M 74 (6), M 73 (13), M 38 (4), M 30 (6), E 170 (7), E 28 (Pr.), E 24 (Pr.), E 13 (80)*, E 12 (1), E 9 (1), E 5 (40)*, E 4 (740)*, E 3 (3660)*, V 13 (40), V 1 (60), II 68 (49), III 320 (1).

REMARKS - It occurs sparingly in the samples where $C$. giesbrechti is very numerous. The greatest percentage of this copepod occurred in waters where the salinity of some layers was under $34.00 \%$. More samples should be examined to establish its preferential environment.

\section{Ditrichocorycaeus africanus Dahl}$$
\text { Size - }+1.2 \mathrm{~mm} ; \sigma^{*}
$$

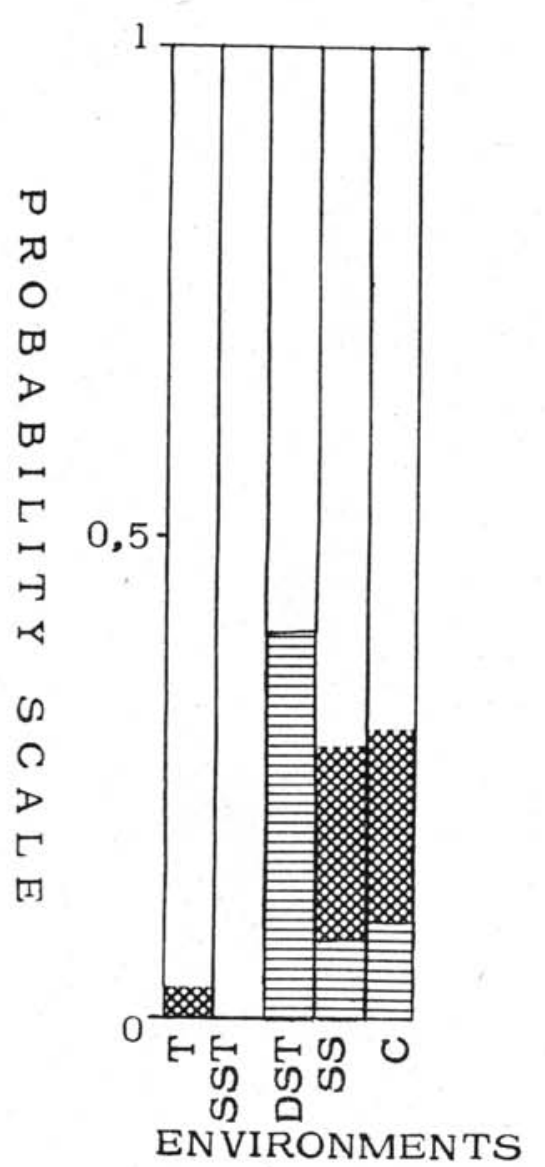

Fig. 44 - Probability of occurrence of Corycaeus amazonicus in different environments. 
OCCURRENCE - M 283 (12), M 265 (1200)*, M 163 (2), M 75 (9).

REMARKS - It occurred in samples off the northern coast in low salinities and high temperatures and in small numbers off the South of Brazil. Klevenhusen (1933, tab. 38) and Dahl (1912, p. 63-64) only registered it off the Atlantic coast of Africa.

\section{Corycaeus speciosus Dana}

(Fig. 45)

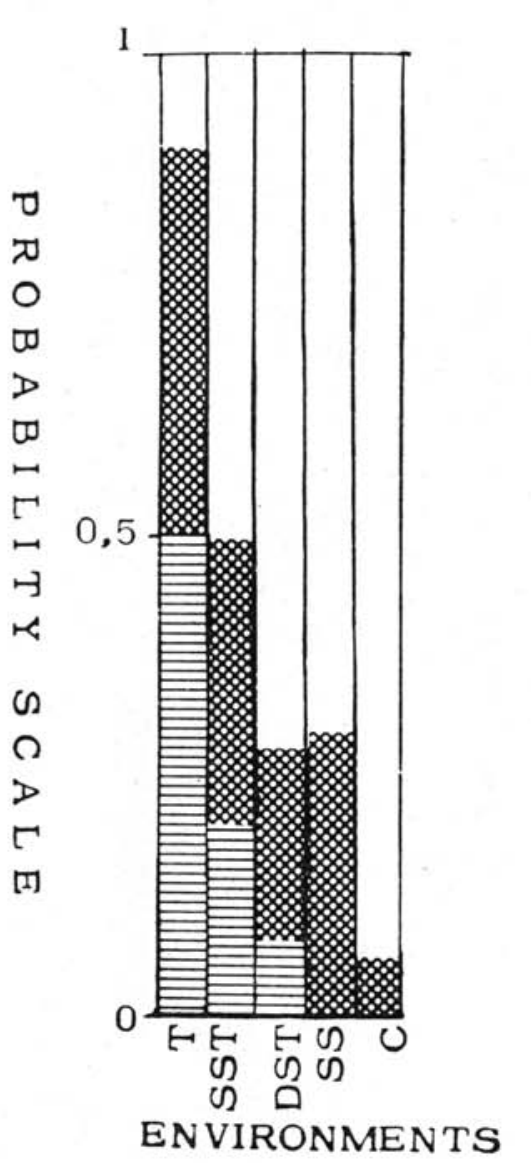

Fig. 45 - Probability of occurrence of Corycaeus speciosus in different environments.
$2.5 \mathrm{SIZE}-$ o $1.95 \mathrm{~mm} ;$ ㅇ

OCCURRENCE - M 497 (7), M $489(720) *$, M $451(40)$, M 409 (2), M 407 (4), M 403 (80), M $402(160)^{*}$, M $394(120)^{*}$, M $389(40)^{*}$, M $368(2)$, M 364 $(80)^{*}$, M 363 (4), M 315 (27), M 314 (12), M 247 (6), M 246 (29), M 245 (16), M 244 (11), M 243 (20), M 242 (63), M 241 (34), M 240 (41), M 232 (42), M 238 (3), M 208 (1), M 144 (1), M 113 (1), M 111 (3), M 100 (1), M 99 (23), M 98 (11), M 97 (11), M 96 (4), M 95 (Pr.), M 76 (7), M 74 (1), M 39 (1), M 37 (8), M 36 (7), M 35 (1), M 33 (1), P 2 (1).

REMARKS - It occurred in nearly all samples of very saline waters $(35.50 \%$ or more $)$. The highest percentages were found in waters with temperatures above $26^{\circ} \mathrm{C}$. It is therefore a typical indicator of warm tropical oceanic water when in larger numbers. Juvenile forms were also found in these waters. 


\section{Other Corycaeus species}

Corycaeus (Agetus) flaccus Giesbr., Corycaeus (Agetus) limbatus Brady (o 1.4-1.3 mm); Corycaeus (Agetus) typicus Kröyer $\left(\sigma^{*} 1.5 \mathrm{~mm}\right)$; C. Onychocorycaeus latus Dana (o 1.15 $\mathrm{mm}$; ᄋ $1.12 \mathrm{~mm})$; C. Corycaeus clausi F. Dahl (ㅇ $1.7 \mathrm{~mm}) ; C$. Urocorycaeus lautus Dana, C. Corycaeus crassiusculus Dana occurred in samples of deep and of surface waters with salinity above $35.50 \%$ and temperatures above $15^{\circ} \mathrm{C}$ approximately. The most frequent of these was $C$. latus (Fig. 46). They were never numerous, usually under $10 \mathrm{spec}-$ imens per sample. The concomitant presence of these species of Corycaeus is usually an index of open-sea waters off Brazil. Nearly all these forms are considered subtropical by Dahl (1912, p. 129) but are really thermophile and therefore tropical and subtropical as to temperature preferences, and according to Klevenhusen $(1933$, p. 81) indicators of oligotrophic regions in the South Atlantic.

\section{Genus CORYCELLA Farran (=Farranula Wilson)}

Corycella gracilis

(Dana)

(Fig. 47)

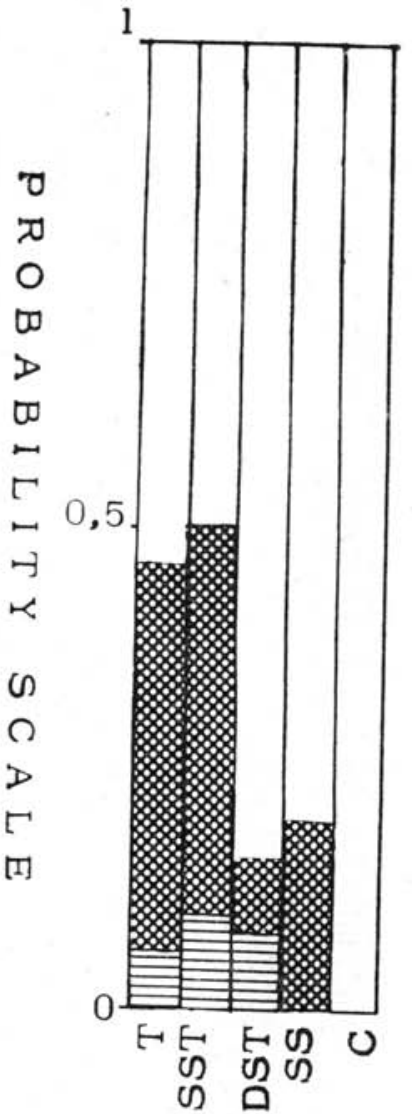

EN VIRONMENTS

Fig. 46 - Probability of occurrence of Corycaeus latus in different environments.

SIZE $-\sigma^{\pi} \quad 0.8-1.0 \mathrm{~mm}$; $+0.93-1.1 \mathrm{~mm}$.

OCCURRENCE - M 513 (1), M 510 (26), M 497 (165), M 489 (5460)*, M 451 (160), M 409 (12), M 407 (9), M 402 (120)*, M $400(1)$, M $394(200)^{*}$, M $389(80)^{*}$, M 368 (28), M 365 $(920) *$, M $364(1920) *$, M 363 (82), M 315 (116), M 314 (94), M 247 (83), M 246 (144), M 245 (39), M 244 (37), M 243 (16), 
M 242 (40), M 241 (148), M 240 (326), M 238 (36), M 236 (1), M $232(480)^{*}$, M $189(86)$, M 188 (34), M 187 (15), M 186 (2), M 114 (1), M 113 (21), M 112 (8), M 111 (16), M 100 (28), M 99 (474), M 98 (312), M 97 (63), M 96 (43), M 95 (89), M 88 (3), M 78 (3), M 75 (6), M 74 (1), M 73 (2), M 39 (13), M 38 (70), M 37 (120), M 36 (107), M 35 (56), M 33 (32), M 32 (1), M 30 (2), E 41 (120)*, E 16 (20)*, E 4 (17), E 3 (26), E 2 (260)*, P 11 (1).

REMARKS - The most frequent Corycaeid, besides $C$. giesbrechti. It occurred in all water masses examined here, excepting in some of the coastal waters. It was numerically the first or

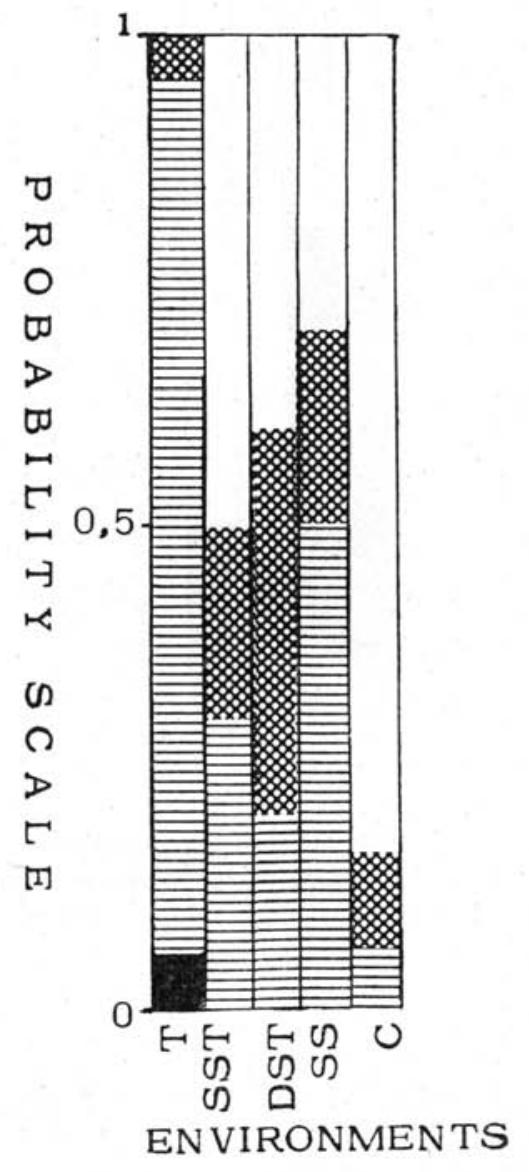

Fig. 47 - Probability of occurrence of Corycella gracilis in different environments. second placed copepod species in warm and saline waters (above $35.5 \%$ and above $21^{\circ} \mathrm{C}$ ) as was also observed by Farran (1929, p. 295). In cold very saline waters it diminished in number or disappeared completely. It was usually sparingly and rarely present in deep cold shelf waters. In coastal waters it was rare and appeared in small numbers. Although small, when in large numbers, it is a good indicator of very saline, warm waters, because of its bright colour (blue, when kept in formalin).

\section{Corycella rostrata (Claus)}

(Fig. 48)

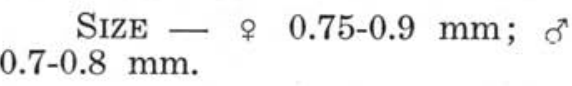

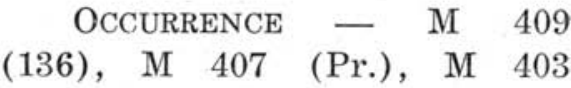
(640), M $402(920)^{*}$, M 400 (34), M 395 (162), M 394 $(4880) *$, M 166 (19), M 163 (88), M 162 (69), M 161 (124), M 160 (160), M 76 (52). 
REMARKs - Absent in samples from warm saline waters, this copepod replaces $C$. gracilis in the cool very saline surface subtropical waters (under $21^{\circ} \mathrm{C}$ and above $35.5 \%$ ). It is rarely present in deep shelf water, or in tropical waters and not at all in the surface shelf and coastal waters. A good indicator of surface very saline waters of temperatures between 16 and $18^{\circ}$ C approximately when in large numbers off the coast of Brazil and in other Atlantic waters (Table X) and off New Zealand (Farran 1929, p. 297).

\section{Genus SAPPHIRINA}

\section{J. V. Thompson}

This is another well studied genus for the Atlantic. The following species have been registered for the western South Atlantic (Sewell 1948, p. 452) : $S$. angusta Dana; S. auronitens Claus -sinuicauda Brady; S. intestinata Giesbr.; S. iris Dana; S. lactens Giesbr.; S. nigromaculata Claus; $S$. opalina Dana -darwini Haeckel; S. ovatolanceolata Dana -gemma Dana.

The "Meteor" Expedition

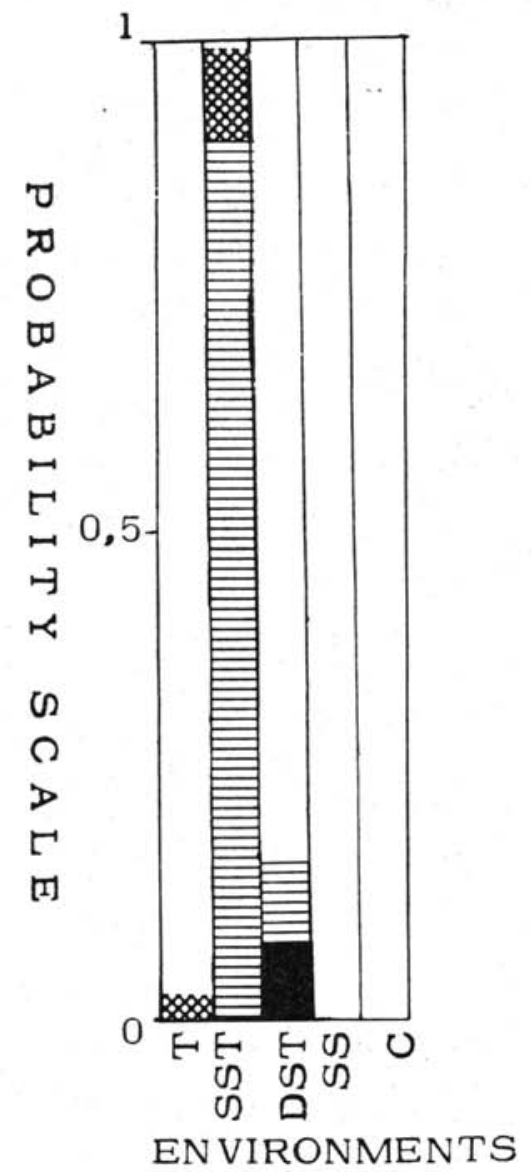

Fig. 48 - Probability of occurrence of Corycella rostrata in different environments. (Steuer 1937, p. 106) registered Sapphirina up to $40^{\circ} \mathrm{S}$ in the Atlantic and noticed a maximum of Sapphirina concentration off the La Plata river's mouth at the limit between the Brazil and the Falkland Currents. The same was observed for the Corycaeidae and for Copilia. Off the Brazilian coast the following Sapphirina were recorded during the expedition: $S$. angusta off the northern coast and off Rio Grande do Sul (4 specimens) ; S. intestinata (7) off Rio Grande do Sul, Florianópolis, Rio de Janeiro; S. auronitens (2), off Rio Grande do Sul; S. ovatolanceolata (5), off Rio Grande do Sul; S. nigromaculata (2 specimens) off Rio Grande do Sul and Rio de Janeiro (Steuer 1937, p. 104-105, tab. 22). 
The following Sapphirina occurred in small numbers and not frequently in our samples:

S. maculosa (two in sample M 240);

S. auronitens - sinuicauda (one in each of the samples M 243 and M 98);

S. metallina (one in M 365 and one in M 368);

S. intestinata (in M 403 [2] and in M 78 [2]);

S. opalina - darwini (in sample M 395 [1], M 189 [1], M 403 [2] and M 240 [1]);

Sapphirina stellata in the samples M 243 (3), M 242 (2), M 75 (7), M 98 (4). Two species were more frequent though they were always present in small numbers: $S$. angusta and $S$. nigromaculata.

Thus three species registered for the western South Atlantic were not registered in our samples. In the samples studied, three Sapphirina were found which had not yet been registered off our coast.

Some occurred in colder very saline waters (S. intestinata), but mostly these animals seem to be thermophile, preferring high salinities.

\section{Sapphirina angusta Dana}

SIZE - o $5.2 \mathrm{~mm}$; ㅇ $2.35 \mathrm{~mm}$ (juv.).

OCCURRENCE - M 402 (Pr.), M 368 (Pr.), M 364 (480)*, M 363 (Pr.), M 247 (7), M 113 (1), M 98 (1).

REMARKS - This species appeared in small numbers in six out of thirty-one samples of tropical water. It also occurred once in very saline, cold, surface water in the South.

\section{Sapphirina nigromaculata-scarlata Claus}

$$
\text { SIZE — \& } 1.65 \mathrm{~mm} \text {; }{ }^{\top} 2.5 \mathrm{~mm} \text {. }
$$

OCCURRENCE - M 407 (2), M 402 (Pr.), M 394 (80)*, M 364 (80)*, M 247 (1) ?, M 241 (1), M 240 (3), M 236 (1), M 189 (1), M 74 (1), M 35 (1), V 1 (1).

REMARKs - It occurred in five out of thirty-one samples of tropical water and in samples of very saline, cold surface southern water. 


\section{Genus COPILIA Dana}

In a revision of this circumtropical genus, Lehnhofer (1926, p. 115-117) mentions that for the Brazil Current very little is known. C. vitrea Haeckel was registered off the northern coast of Brazil (in the South Equatorial Current and Gulf of Guinea); C. mirabilis, off the northern coast of Brazil, off Rio Grande do Sul (off the African coast in the South Equatorial Current; it was the commonest Copilia in the Indian Ocean); C. quadrata, off the North coast of Brazil (off the coast of Africa in the Gulf of Guinea) and C. lata off the North coast of Brazil and off Rio de Janeiro. C. quadrata and C. lata (Lehnhofer 1926, p. 170171) occurred in salinities between 33.3 and $36.5 \%$. C. mirabilis occurred between temperatures of 23 and $29^{\circ} \mathrm{C}$ (only once at $16.3^{\circ} \mathrm{C}$ in the surface) during the "Valdivia" Expedition and was therefore considered as "almost warm-stenotherm" (Lehnhofer 1926, p. 458). It was the most numerous species caught by the "Valdivia" and here too. In our waters it occurred also in lower temperatures and all along the coast of Brazil.

Copilia is not mentioned in the reports of the "Plankton" Expedition samples. The "Meteor" Expedition collected several Copilia (Steuer 1937, p. 109-114), but very sparingly off the Brazilian coast. Copilia mirabilis Dana was registered off Rio Grande do Sul and Copilia lata Giesbrecht in the central South Atlantic and near the northern coast of Brazil, off Fernando de Noronha Island.

\section{Copilia mirabilis Dana}

\section{SIZE - o $6 \mathrm{~mm}$; o $5.8 \mathrm{~mm}$.}

OCCURRENCE - M 402 (Pr.), M 364 (160)*, M 363 (Pr.), M 315 (6), M 314 (1), M 247 (2), M 246 (7), M 245 (2), M 244 (1), M 243 (6), M 242 (3), M 241 (14), M 240 (9), M 189 (2), M 188 (3), M 187 (4), M 173 (Pr.), M 114 (2), M 112 (1), M 107 (12), M 100 (1), M 99 (3), M 97 (1), M 93 (13), M 78 (3), M 76 (1), M 75 (8), M 74 (4), M 39 (3), M 38 (5), M 37 (13), M.36 (17), M 35 (14), M 31 (1), E 164 (1), E 41 (Pr.), E $15(20)^{*}$, E 13 (280), E 11 (60)*, V 19 (13), P 1 (Pr.).

REMARKS - Present in small percentages in 5 out of 31 samples of coastal waters; present in small percentages also in tropical and subtropical waters. It reached the highest numbers in the shelf waters. As can be seen from the general distribution, it prefers warmer waters. The samples with most specimens had temperatures between 22.97 and $21^{\circ} \mathrm{C}$. Lehnhofer (1926, p. 458) 
registered it chiefly in higher temperatures and so did Dahl (1892, p. 514).

\section{Copilia quadrata Dana}

Size — $+1.7 \mathrm{~mm}$ (juvenile).

OCCURRENCE - M 403 (3), M 246 (1), M 240 (6).

REMARKS - It occurred rarely in small numbers in samples of tropical water (M 246 and M 240) and in a single sample of subtropical water. Dahl (1892, p. 516) mentions it as a subtropical southern Atlantic form.

\section{Copilia lata Giesbr.}

SizE - $55.6 \mathrm{~mm}$.

OCCURRENCE - M 242 (1).

REMARKS - Supposed to occur over all the Atlantic (Dahl 1892 , p. 512) it was observed only once in a sample taken off the northern coast of Brazil in warm and very saline waters. The "Meteor" Expedition also registered it off the northern coast of Brazil (Steuer 1937, p. 112-113).

\section{Copilia vitrea (Haeckel)}

$$
\text { SIZE }-\sigma^{7} 8.01 \mathrm{~mm} \text {. }
$$

OCCURRENCE - M $365\left(\begin{array}{ll}1 & \sigma^{\star}\end{array}\right)$.

REMARKs - Only one specimen, a male, was found in one sample taken between the latitudes of Rio de Janeiro and Santos in tropical water of the Brazil Current.

\section{Copilia mediterranea (Claus)}

$$
\text { Size — o } 4 \mathrm{~mm} \text {; ơ } 5.5 \mathrm{~mm} \text {. }
$$

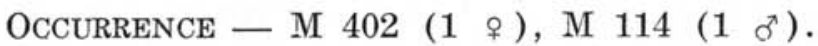

REMARKS - Only two specimens were registered in very saline, under $21.3^{\circ} \mathrm{C}$ surface waters. It had not been registered before in Brazilian or South American waters. 
THE ENVIRONMENTS

COASTAL W A TER S

If the plankton volume is compared in Brazilian coastal waters, an average of $1.49 \mathrm{ml} / \mathrm{m}^{3}$ is found, ranging from $0.09 \mathrm{ml} / \mathrm{m}^{3}$ (in sample M 283) to $8.6 \mathrm{ml} / \mathrm{m}^{3}$ (in sample E 41). These are undoubtedly the richest of Brazilian waters (Table II). Hentschel (1933, p. 146) showed that the highest number of plankters in the western South Atlantic in the surface layer of sea water lived in a narrow band, a hundred kilometers wide along the South American coast. Thus our data support Hentschel's.

Hentschel (1933, p. 149) also found higher numbers of plankters in the southern colder waters off the coast of South America, from $25^{\circ} \mathrm{S}$ Lat. to $55^{\circ} \mathrm{S}$ Lat.

Plankton volumes obtained by settlement were the largest, 0.4 to $8.6 \mathrm{ml} / \mathrm{m}^{3}$, at the stations off Cananéia (about 28 $8.4^{\prime} \mathrm{S}$ $\left.47^{\circ} 44.2^{\prime} \mathrm{W}\right)$. Volumes 0.3 to $0.8 \mathrm{ml} / \mathrm{m}^{3}$ were obtained in samples from $25^{\circ} \mathrm{S}$ to $23^{\circ} \mathrm{N}$. The same volume occurred in the South $\left(32^{\circ} 23.5^{\prime} \mathrm{S}\right)$ off the outlet of the Lagoa dos Patos. In the North near the mouth of the Amazon River there were also larger volumes 0.34 to $0.8 \mathrm{ml} / \mathrm{m}^{3}$ for total plankton collected by zooplankton nets. This had also been verified by Hensen (1911, tab. III-IVV) who found the largest number of copepods and diatoms in the north coast of Brazil off the mouth of the Tocantins River.

The poorest coastal water samples were M 283 from the north $\left(02^{\circ} 46.0^{\prime} \mathrm{N}-49^{\circ} 35.0^{\prime} \mathrm{W}\right)$ and $\mathrm{M} 203$ from the south $\left(30^{\circ} 48.7^{\prime} \mathrm{S}-\right.$ $50^{\circ} 28.3^{\prime} \mathrm{W}$ ) both from regions far away from river mouths or sound outlets.

Relatively to the volume of phytoplankton in these waters, the volume of copepods is frequently small, whereas in other waters it may even exceed that of the phytoplankton. In our coastal waters the copepods usually dominant in volume are Centropages furcatus, Temora stylifera, Oncaea media and Acartia spp.. In our colder waters Ctenocalanus vanus is dominant in volume. Occasionally Oithona and Pseudodiaptomus may be the dominant species in lower salinity.

Forty-five samples of coastal water were examined, 31 of which were separated as representatives of different seasons, different regions, different temperature and salinity (Tables I and III). The great majority of samples was taken off the southern coast of Brazil and the conclusions are usually valid for that region. 


\begin{tabular}{|c|c|c|c|c|c|c|c|c|c|c|c|c|c|c|c|}
\hline 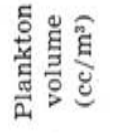 & $\begin{array}{l}\infty \\
0\end{array}$ & $\stackrel{n}{0}$ & $\stackrel{10}{0}$ & ถั & 1 & $\stackrel{7}{*}$ & 1 & $\ddot{0}$ & 1 & 1 & 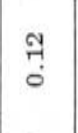 & $\underset{\infty}{\varphi}$ & $\stackrel{10}{10}$ & $\stackrel{\circ}{+}$ & r \\
\hline 珰 & $>$ & 丰 & 届 & 出 & 出 & 田 & 出 & 0 & I & 0 & 届 & 出 & 出 & 出 & 步 \\
\hline 苂 & us & ต่ & نी & $\stackrel{\oplus}{\dot{0}}$ & $n$ & ตें & 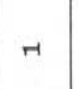 & in & $N$ & Un & ભ̣ & 乌் & 乌ُ & $\stackrel{m}{\dot{0}}$ & mं \\
\hline छ્ & $\begin{array}{l}\text { \& } \\
\text { జू }\end{array}$ & ๙ิ & 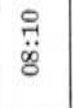 & 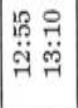 & $\begin{array}{l}\stackrel{\text { }}{\ddot{g}} \\
\stackrel{8}{8}\end{array}$ & 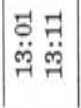 & $\begin{array}{l}\ddot{\wp} \\
\ddot{\sim} \\
\ddot{\sim}\end{array}$ & 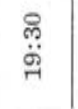 & 1 & $\begin{array}{l}18 \\
\ddot{8}\end{array}$ & 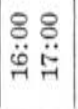 & 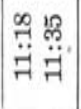 & $\begin{array}{ll}\infty & \overrightarrow{1} \\
\ddot{n} & 0 \\
\ddot{g} & \ddot{8}\end{array}$ & 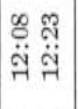 & $\begin{array}{l}\ddot{m} \\
\ddot{g} \\
\ddot{g}\end{array}$ \\
\hline 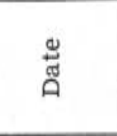 & 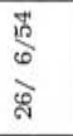 & $\begin{array}{l}\frac{0}{0} \\
5 \\
\text { 둑 }\end{array}$ & $\begin{array}{l}\text { i⿱ 口) } \\
\text { సิ }\end{array}$ & $\begin{array}{l}\frac{9}{10} \\
\text { i⿱ } \\
\text { Iิ }\end{array}$ & $\begin{array}{l}\text { i⿱ } \\
\text { के } \\
\text { के }\end{array}$ & 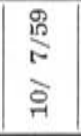 & $\frac{10}{\infty}$ & in & 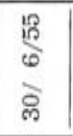 & $\begin{array}{l}\text { 量 } \\
\text { c } \\
\text { ch }\end{array}$ & $\begin{array}{l}\frac{9}{8} \\
\text { है } \\
\text { คे }\end{array}$ & 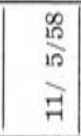 & $\begin{array}{l}\infty \\
\text { in } \\
\text { in } \\
7\end{array}$ & $\begin{array}{l}\sum_{\infty}^{\infty} \\
\text { ह } \\
\text { ล }\end{array}$ & हె \\
\hline 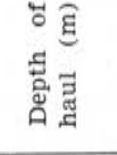 & ํㅗㅁ & สิ & 육 & $\stackrel{10}{\sim}$ & 总 & $\stackrel{10}{7}$ & के & $\begin{array}{l}\stackrel{i}{1} \\
\stackrel{\sim}{\pi}\end{array}$ & 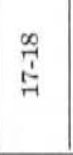 & ホิ & $\stackrel{ }{\rightarrow}$ & $\stackrel{12}{\mathrm{~N}}$ & $\stackrel{10}{7}$ & I & $\stackrel{10}{7}$ \\
\hline 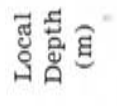 & $\underset{\sim}{ت}$ & ฉึ & $\stackrel{\oplus}{\oplus}$ & సิ & 유 & กิ & 구 & స్ & 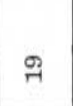 & ล & 둑 & లి & กิ & নి & సి \\
\hline 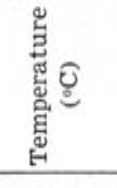 & ते & ํㅗ․ & ๙ู่ พิ & ڤి & 오 & 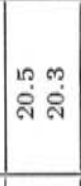 & $\begin{array}{l}\sigma \\
\dot{\varphi}\end{array}$ & 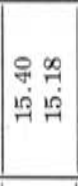 & $\ddot{g}$ & 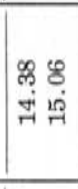 & ஜें & 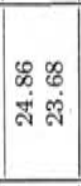 & $\begin{array}{ll}8 & 9 \\
0 & \vdots \\
\text { సें } & \text { సे }\end{array}$ & $\begin{array}{l}\text { 유 สิ } \\
\text { มุ่ }\end{array}$ & - \\
\hline 雍 & 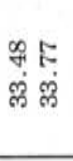 & $\begin{array}{l}\mathscr{D} \\
\ddot{m}\end{array}$ & $\begin{array}{l}\text { 苟 } \\
\text { लें }\end{array}$ & 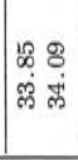 & ஜீ. & 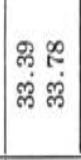 & 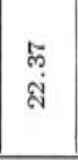 & 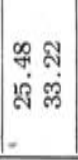 & है & 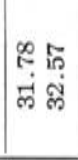 & है & m 유 & 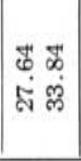 & 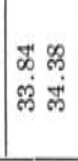 & $\begin{array}{l}5: 18 \\
\text { ले }\end{array}$ \\
\hline 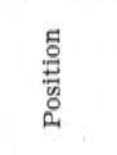 & 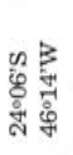 & 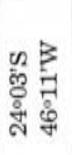 & 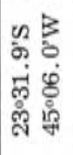 & 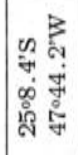 & 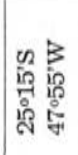 & 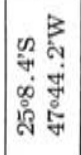 & 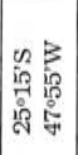 & 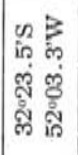 & 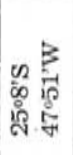 & 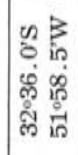 & 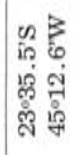 & 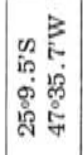 & 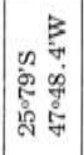 & 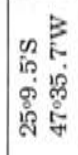 & 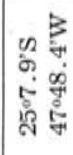 \\
\hline 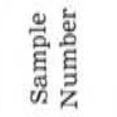 & 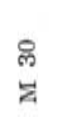 & 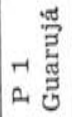 & 움 & $\begin{array}{l}\text { 苟 } \\
\text { का }\end{array}$ & $\begin{array}{l}\text { ลี } \\
\text { Z }\end{array}$ & $\begin{array}{l}\text { 욱 } \\
\text { 되 }\end{array}$ & $\begin{array}{l}\text { N } \\
\text { 己 }\end{array}$ & $\begin{array}{l}\infty \\
\infty \\
z\end{array}$ & $\begin{array}{l}0 \\
0 \\
G\end{array}$ & $\begin{array}{l}\infty \\
\infty \\
\sum\end{array}$ & $a$ & F & 离 & $\begin{array}{l}\text { कू } \\
\text { क्ष }\end{array}$ & $\begin{array}{l}\text { ลิ } \\
\text { ต }\end{array}$ \\
\hline
\end{tabular}




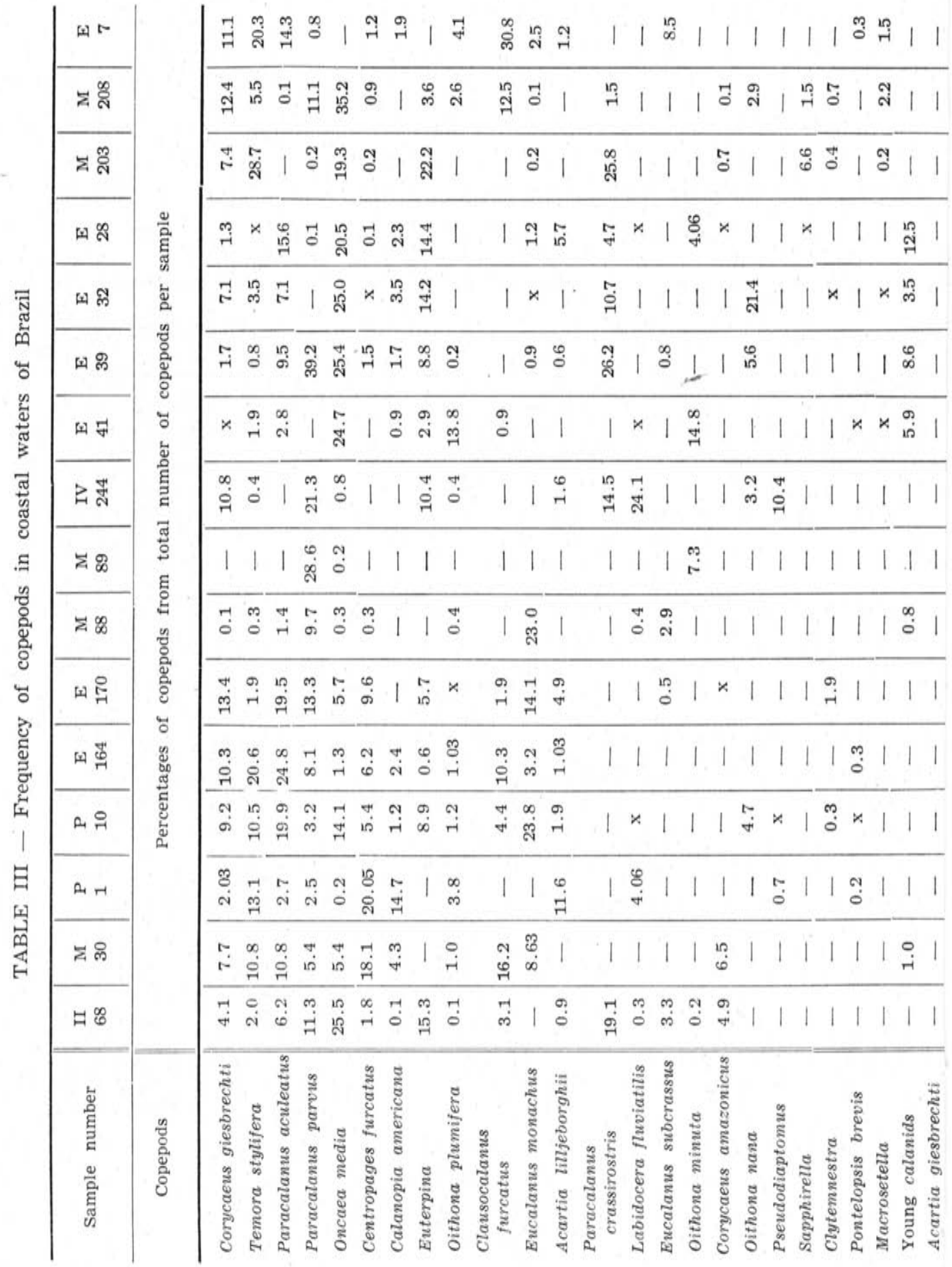




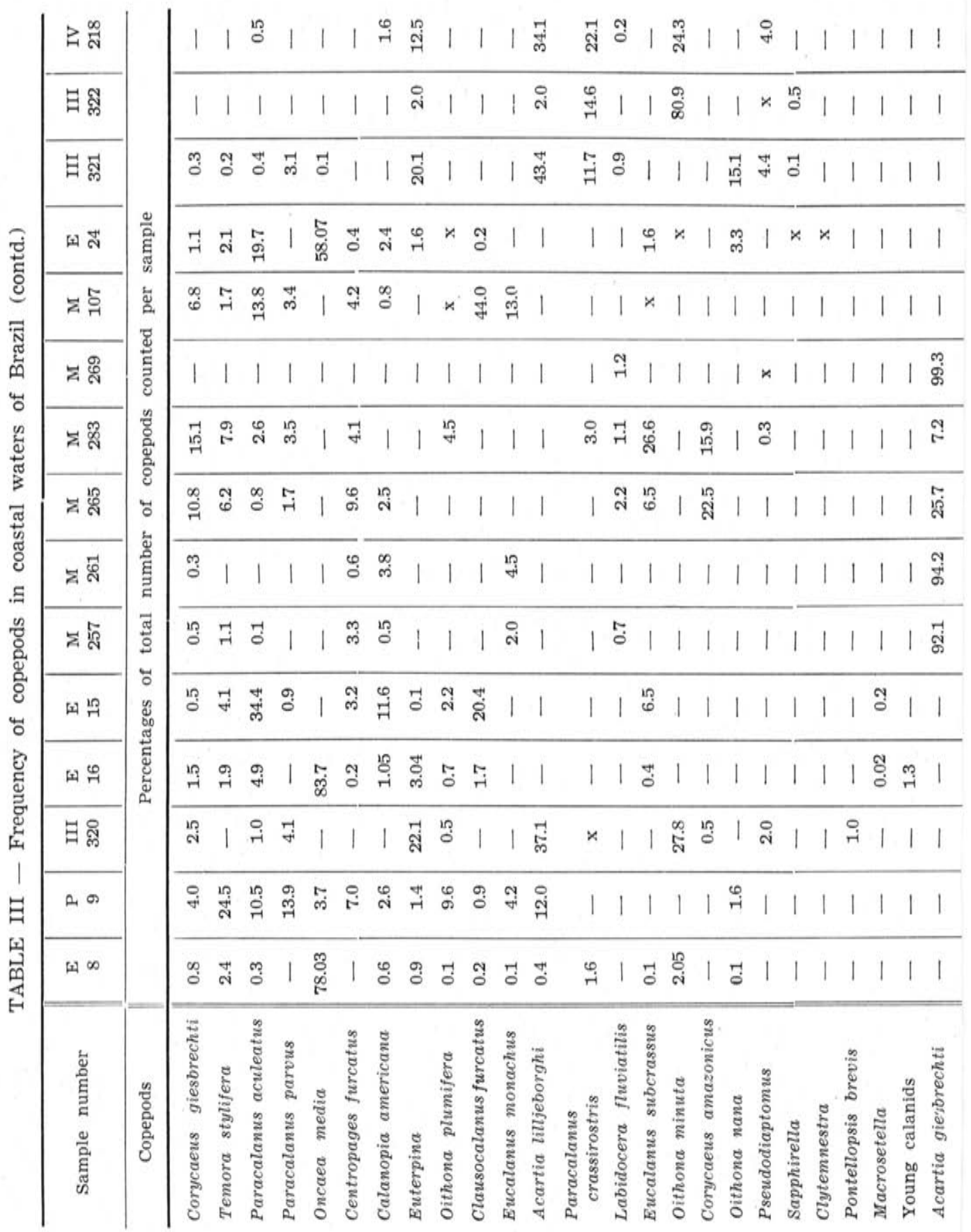


| | | | | | | \& | | | | | | | | | | | | | | | | | | |

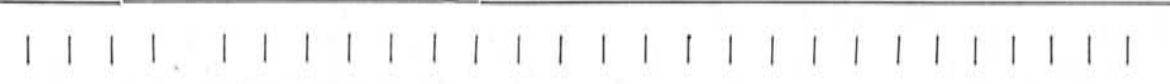

$1|1| 1|1| 1|1| 1|1| 1|1| 1|1| 1 \mid 1$

$1 * 11|1| 1|1| 1|1| 1|1| 1|1| 1|1|$

|1 1 \& $1|1| 1|1| 1|1| 1|1| 1|1| 1 \mid *$

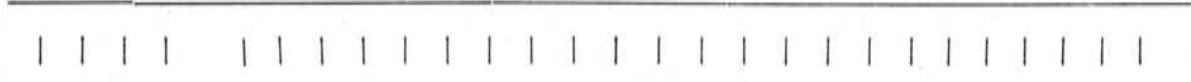

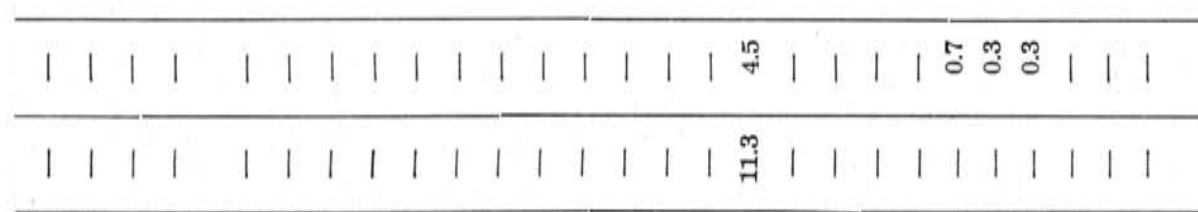

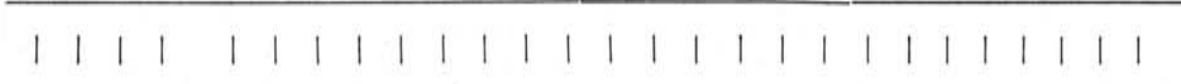

1 1 1 1 1 1 1 1 1 1 1 1 1 1 1 1 1 1 1 1 1 1 1 1 1

| | | ํํㅇ | | | | | | | | | | | | | | | | | | | | ํํㅇ |

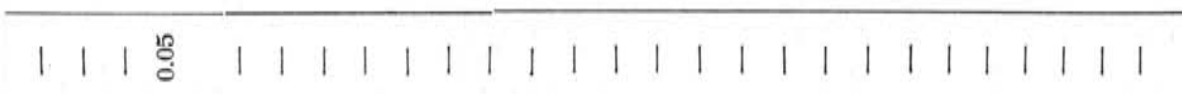

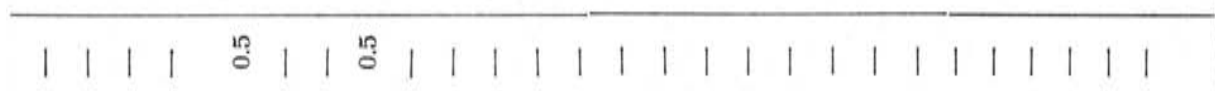

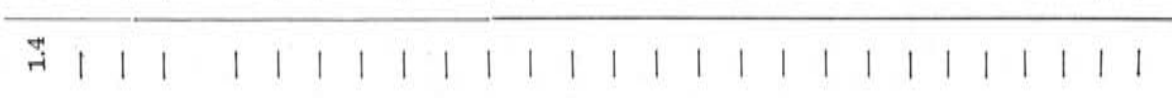

| | | ส ส | | | | |

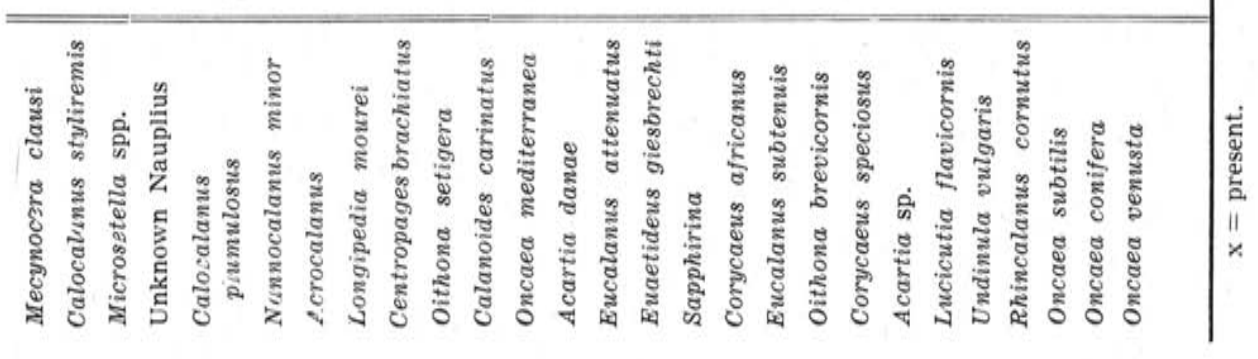


TABLE II - Plankton volume in different marine environments off Brazil

\begin{tabular}{|c|c|c|c|c|c|}
\hline Environments & $\begin{array}{l}\text { Coastal } \\
\text { water }\end{array}$ & $\begin{array}{c}\text { Surface } \\
\text { shelf water }\end{array}$ & $\begin{array}{c}\text { Deeper } \\
\text { shelf water }\end{array}$ & $\begin{array}{c}\text { Surface } \\
\text { subtropical } \\
\text { water }\end{array}$ & $\begin{array}{l}\text { Tropical } \\
\text { water }\end{array}$ \\
\hline Salinity $(\%)$ & $8.2-34.8$ & $34.8-35.9$ & $35.1-35.9$ & $35.9-36.9$ & $35.8-37.2$ \\
\hline $\begin{array}{l}\text { Temperature } \\
\text { (॰C) }\end{array}$ & $14.3-28.1$ & $20.0-28.8$ & $15.2-20.5$ & $17.0-23.0$ & $21.0-28.0$ \\
\hline $\begin{array}{l}\text { Plankton volume } \\
\qquad\left(\mathrm{cc} / \mathrm{m}^{3}\right)\end{array}$ & $0.09-8.9$ & $0.09-1.5$ & $0.03-4.0$ & $0.03-0.16$ & $0.03-1.2$ \\
\hline Average $\left(\mathrm{cc} / \mathrm{m}^{3}\right)$ & 1.49 & 0.57 & 1.10 & 0.08 & 0.23 \\
\hline$\frac{\text { Average }}{4}$ & $0.37 \mathrm{cc} / \mathrm{m}^{3}$ & $0.11 \mathrm{cc} / \mathrm{m}^{3}$ & $0.27 \mathrm{cc} / \mathrm{m}^{3}$ & $0.02 \mathrm{cc} / \mathrm{m}^{3}$ & $0.05 \mathrm{cc} / \mathrm{m}^{3}$ \\
\hline
\end{tabular}

The largest number of copepod species in coastal waters respectively 25 and 23 were found in samples M 208 and M 88 off the very south of Brazil, in temperatures ranging from 15, 18 to $23.9^{\circ} \mathrm{C}$ and in low salinity, 25.48 to $33.00 \%$. The samples listed in Table III show an average of 14 to 15 different copepod species. The smallest number of species found was 3 and 5 in a sample taken off the Amazon River's mouth and at Cananéia. In both instances the waters sampled had very low salinities (below $20 \%$ ) at the surface, due to the discharge of the river or sound. The great local variability of environmental conditions was probably the cause of the small number of species in these two samples.

When horizontal and vertical hauls were made at the same station the largest number of species was always in the sample collected vertically, because more layers of water were sampled. The coastal waters show the greatest variety of copepod associations, corresponding to the variable characteristics of the environment which presents many biotopes.

As Jakobi (1953, p. 14) pointed out the greater abundance of Pseudodiaptomus in relation to Oithona is an index of lower salinity of coastal waters. The same may be said here concerning the abundance of Labidocera fluviatilis and certain harpacticids (Longipedia) in relation to Acartia lilljeborghi and to Temora stylifera.

Table III also shows that the association of species characteristic of Brazilian coastal waters is:

Corycaeus giesbrechti, Paracalanus aculeatus and $P$. parvus, Temora stylifera, Oncaea media, Centropages furcatus all of which 
with a probability of occurring usually in the highest percentage of the total number of copepods counted per sample and in more than 20 samples in every 31 examined; Clausocalanus furcatus in high percentages of the total number of copepods counted per sample; Oithona plumifera, Eucalanus monachus and E. subcrassus, Oithona nana, Acartia lilljeborghi, Calanopia americana, Euterpina acutifrons, Paracalanus crassirostris with a probability of occurring in more than 10 in every 31 samples examined. Some of these may represent $30 \%$ of the total number of copepods present. Some species are found only in coastal waters, though in only one or a few samples and usually in small numbers. As they did not appear in more saline waters it is probable that they thrive in brackish water or in other types of water and are "visitors" of coastal waters: Pseudodiaptomus acutus and P. richardi, Sapphirella sp., Labidocera fluviatilis, Oithona minuta, O. ovalis, Pontellopsis brevis, Centropages brachiatus, Longipedia mourei, Corycaeus africanus, Acartia giesbrechti, Parathalestris.

Pseudodiaptomus acutus was very numerous in two samples taken from inshore waters at Cananéia. Centropages brachiatus seems to substitute Centropages furcatus in very cold southern coastal waters. Corycaeus amazonicus and $C$. africanus may partly substitute $C$. giesbrechti. The second only appeared in the northern warm waters off Brazil and the first also in the south. Acartia lilljeborghi is substituted by $A$. tonsa in the cold southern coastal waters and by $A$. giesbrechti in the warm coastal waters of the north. Pseudodiaptomus richardi is the substitute of $P$. acutus in less saline northern coastal waters. Labidocera fluviatilis and Oithona ovalis also seem to be strays from brackish waters.

Ctenocalanus vanus, Nannocalanus minor, Acartia danae, Corycaeus gracilis, Mecynocera clausi, Calocalanus pavo, Microsetella sp., Euaetideus giesbrechti, Oncaea subtilis, O. conifera, O. venusta, O. mediterranea, Clytemnestra sp., Acrocalanus sp., Saphirina sp., Copilia mirabilis, Macrosetella sp., Oithona setigera and $O$. brevicornis, Corycaeus speciosus, Calocalanus tenuis, Calanoides brevicornis, Undinula vulgaris, Rhincalanus cornutus are visitors in this environment from other waters.

Longipedia mourei is known to live in the muddy sand covered by shallow brackish water in the bay of Paranaguá. According to Hensen's (1911, p. 316) observations of harpacticids it can be considered an indicator of inshore waters, as it was also found in the Mar de Cananéia, under strong influence of alternating salty coastal waters and almost fresh waters from the Ribeira River. Bottom harpacticids were numerous in the Tocantins River and banks (Hensen 1911, p. 316). 
The following table grossly summarizes the data on coastal waters from divers parts of the world, where hydrographical conditions were also observed. We find that the characteristic genera for these waters are Centropages, Temora, Acartia, Labidocera, Paracalanus, Oithona, Oncaea, Corycaeus, Pseudodiaptomus, Euterpina and Microsetella. The first six genera are present in nearly all lists of coastal copepoda (Table IV). These are also the waters visited by tychopelagic copepods mostly living on or near the bottom or on algae, such as Bradya limicola, Harpacticus chelifer and other representatives of the genera Harpacticoida. These are absent from open-sea waters and shelf waters.

If we compare the characteristic copepod fauna of coastal waters (Table IV), we notice that they can be roughly divided into three groups: the thermophile Centropages furcatus group, characteristic of warm coastal waters; the cryophile Centropages hamatus group from cold waters; and waters with different species or without Centropages. Oithona similis and Calanus finmarchicus are also cryophiles of the northern hemisphere. Calanus finmarchicus is substituted in coastal Antarctic and in the Bering Sea (Brodsky 1957, p. 99) waters by Calanus tonsus (Farran 1936, p. 77) and C. hyperboreus, stenothermic cryophiles, and in some of the warm waters by $C$. pauper. Ctenocalanus vanus, usually characteristic of cold deep shelf waters off our coasts, shows its maxima in numbers in the cold coastal Antarctic waters. It also appears in other cold coastal waters, for instance in California (Table IV) and in coastal waters off the very south of Brazil. The following species, Eucalanus subcrassus, E. monachus, E. subtenuis and Clausocalanus furcatus, although usually shelf water copepods, also appear in large numbers in warm coastal waters. They are restricted to tropical and subtropical areas. Pseudocalanus elongatus is a cold water boreal species. Coastal water copepods are usually more euryhaline than eurythermic. Calanopia, with its various species, is characteristic of warm coastal waters. Corycaeus with several species in warm waters, has only a few adapted to cold environments, such as $C$. anglicus in the North Sea and $C$. inuncus in New Zealand waters.

Of the Paracalanus, $P$. aculeatus is thermophile; $P$. parvus is the most eurythermic, but standing colder environments, better than $P$. aculeatus. $P$. crassirostris seems to be a stenoecius copepod. It usually occurs in coastal waters all over the world.

Coastal copepods are sometimes also good geographical indicators, as has already been pointed out and is emphasized when studying the Acartia species and the Diaptomidae (Table IV). They are usually very stenoecius. 
TROPICAL W A T E S

Tropical waters are here considered as the surface waters (the upper layer of $150 \mathrm{~m}$ ) which show temperatures above $20^{\circ} \mathrm{C}$ and salinities above $36 \%$ (Emilsson 1959, p. 45). These waters are brought in direction to the easternmost part of the Brazilian coast by the South Equatorial Current (op. cit., p. 44) a part of which is deviated to the South, giving rise to the Brazil Current, while the other part continues in a NW direction along the $\mathrm{N}$ coast of Brazil.

The thirty-one samples examined from these waters (Table V) showed salinities between 35.84 and $37.25 \%$ and temperatures between $20.33^{\circ}$ and $28.00^{\circ} \mathrm{C}$. They were taken mostly off the Brazilian continental shelf at stations located from $04^{\circ} 57^{\prime} \mathrm{N}$ to $27^{\circ} 43.5^{\prime} \mathrm{S}$, up to where this kind of environment is found all the year round. Two samples (M 314, M 315) taken near Trindade Island were also examined because their salinities and temperatures were within the limits mentioned above. These waters show a variability of plankton volume from 0.06 to $0.50 \mathrm{ml} / \mathrm{m}^{3}$ (Kanaeva 1960 , p. 184) along the $30^{\circ} \mathrm{W}$ meridian down to $20^{\circ} \mathrm{S}$ in the Atlantic. The samples examined for this work showed values which ranged from $0.077 \mathrm{ml} / \mathrm{m}^{3}$ (observed in southern waters and the farthest away from the coast) to $1.4 \mathrm{ml} / \mathrm{m}^{3}$ off the mouth of the Amazon River. The plankton volume per cubic meter of water off the Brazilian coast showed also larger values in the vicinities of Fernando de Noronha Island, in the South Equatorial Current, off Rio de Janeiro and Santos, and off Santa Catarina. Generally the plankton volume was very low. According to Hentschel (1933, p. 146) the decrease of plankton volume is proportional to the distance from the coast in the South Atlantic. This is confirmed in this paper: the average volume for a band of coastal water nearest the coast is $1.49 \mathrm{ml} / \mathrm{m}^{3}$, that for a band of shelf water next nearest is $0.57 \mathrm{ml} / \mathrm{m}^{3}$, and the smallest volume is observed in the Brazil Current waters, which are the farthest away from the coast $\left(0.23 \mathrm{ml} / \mathrm{m}^{3}\right)$. It shows the rise in plankton volume in the stations nearing the slope and its decrease in stations away from the slope (M 314, M 315). The increase in the Fernando de Noronha area and off the mouth of the Amazon River had also been noticed by Hentschel (1933, beil. $1 \& 2$ ) and by Hensen (1911, p. 52-53, p. 186-187). In volume the dominant copepods in this environment are usually Nannocalanus minor and Clausocalanus furcatus, which although small is usually so numerours that it accounts for large portions of the total plankton. Euchaeta marina, Copilia mirabilis, Neocalanus gracilis, Candacia 


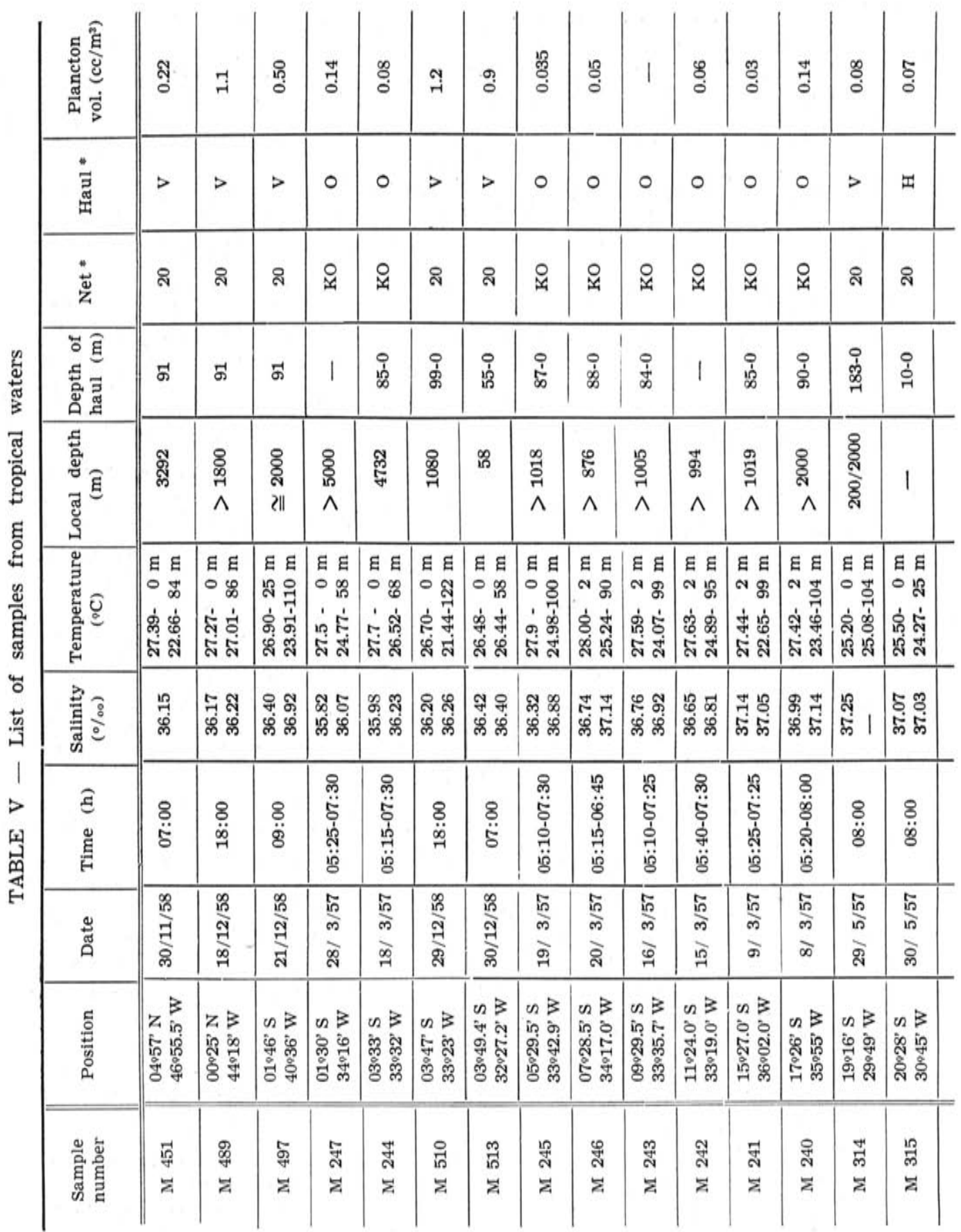




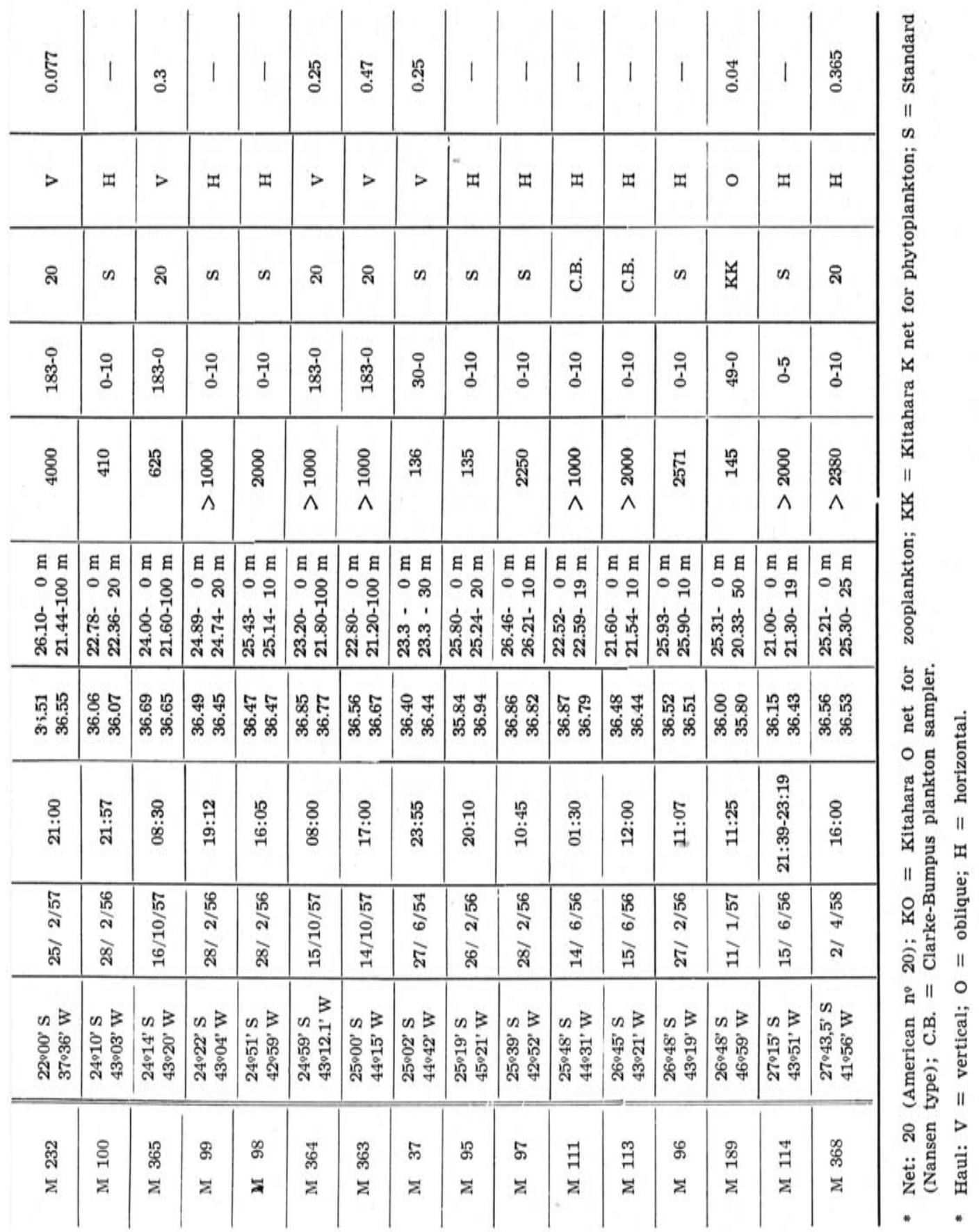


spp. and Scolecithrix sp. may also constitute the dominant volume. When there is a nycthemeral migration from deeper layers and large copepods like Undeuchaeta major reach the surface (M 114) this species is the dominant in size and volume.

Although poor in plankton volume, tropical waters are extremely rich in species (97 recorded in this paper) as is known from other papers. The following copepods were found in all samples (Table VI) but one: Clausocalanus furcatus, Corycella gracilis (or C. carinata), Scolecithrix danae in all stages of development and usually in high percentages. The genus Oithona (with O. plumifera and O. setigera), Undinula vulgaris, Nannocalanus minor, Calocalanus pavo, Euchaeta marina, Acrocalanus longicornis, Corycaeus speciosus, Temora stylifera (usually in low percentages), Mecynocera clausi, Candacia pachydactyla and the genus Oncaea (O. media, O. venusta, O. conifera, the most frequent) were present in 20 or more of the samples taken in the tropical water. The copepods mentioned above seem to constitute a characteristic association for tropical waters in the western South Atlantic. The other copepods usually present are Neocalanus gracilis, Centropages violaceus, Copilia mirabilis, Paracalanus aculeatus, Acartia danae or A. negligens and Corycaeus represented by several species (C. clausi, C. latus, C. furcifer, C. typicus, C. flaccus).

When different lists of open sea copepods from "tropical water" or "warm water" are compared the great number of species of Corycaeidae (Corycaeus and Corycella) may be noticed. In smaller number Sapphirina spp. are also common in warm oceanic waters (Lehnhofer 1929, p. 308). Some species appear in tropical waters but usually in very reduced numbers: Rhincalanus cornutus (or nasutus), Eucalanus attenuatus, Haloptilus acutifrons (or another Haloptilus species), Heterorhabdus papilliger (or another Heterorhabdus species), Temeropia mayumbaensis, Pleuromamma abdominalis (or gracilis), Undeuchaeta (major or minor). These usually appear in tropical surface layers during their nycthemeral migrations from deeper layers.

Table VII compares the general data in the literature and those obtained here. So as to be sure that the same environments are being compared only data were used from regions where the salinities and temperatures could be established as well as the species and when possible, the number of specimens of each species.

Two conclusions may be drawn from Table VII: 1 - the association found in Brazilian waters could be expected, as it confirms earlier data obtained by other authors (Dahl, 1894; Farran, 


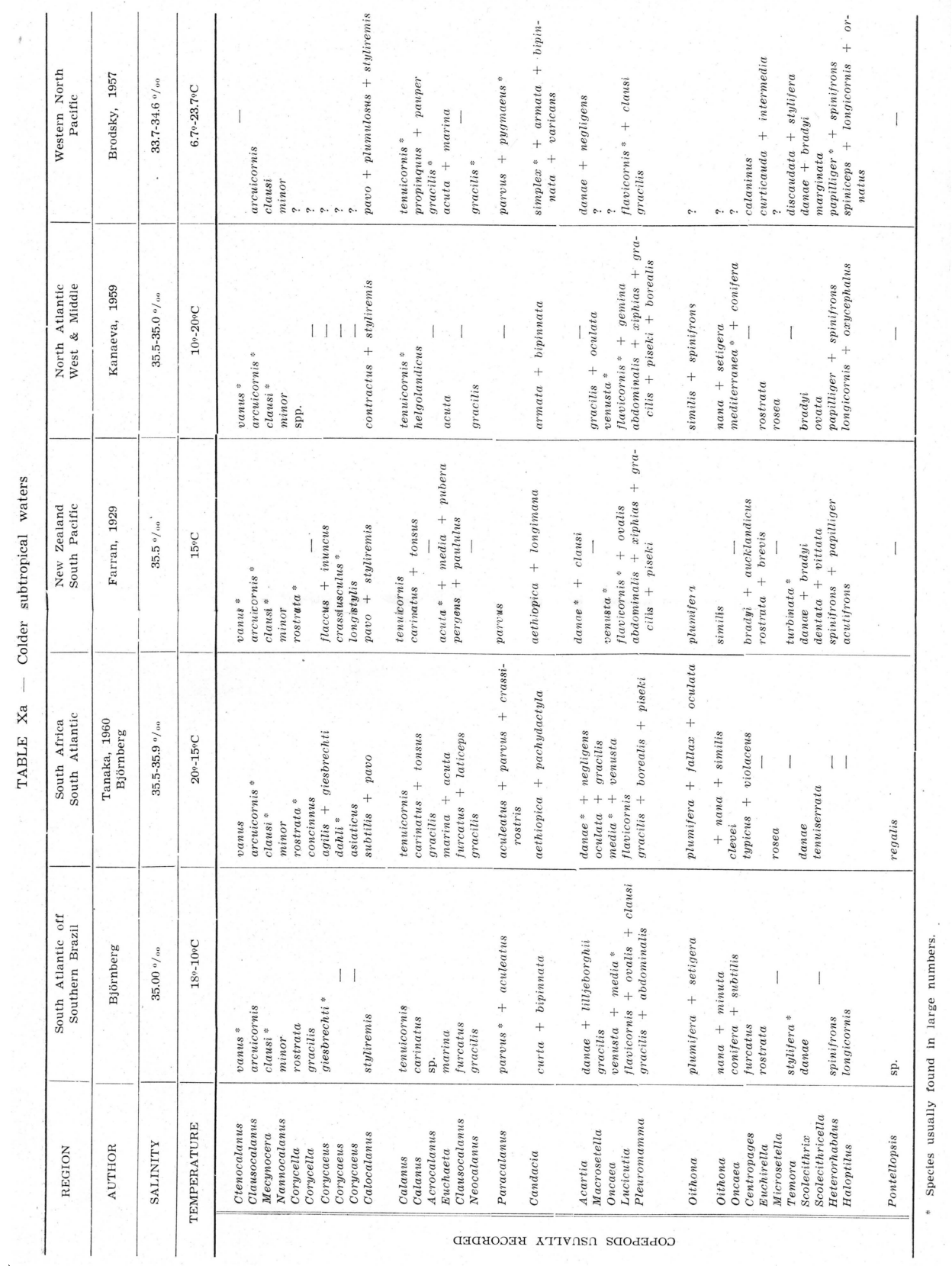




\begin{tabular}{|c|c|c|c|c|c|c|c|c|c|c|}
\hline STATION NUMBER & M 100 & M 365 & M 99 & M 98 & M 364 & M 363 & M 37 & M 95 & M 97 & M 111 \\
\hline COPEPODS & & & Percent & ges o & of copeps & pods in & totat $n$ & number & of cop & ods \\
\hline rycaeus crassiuscut & -1 & -1 & -1 & -1 & - & -1 & & & -1 & \\
\hline ppilia & -1 & $\mathrm{x}$ & - & - & - & $=$ & $=$ & $=$ & - & $=$ \\
\hline Coryca & - & -1 & - & - & $\div$ & - & -1 & - & -1 & - \\
\hline $\begin{array}{l}\text { sp. } \\
\text { na gastrica }\end{array}$ & -1 & - & 0.46 & - & - & - & $\mathrm{x}$ & - & -1 & - \\
\hline $\begin{array}{l}\text { Sapphirina gastrica } \\
\text { Candacia bispinosa }\end{array}$ & $=$ & $\overline{-1}$ & $=$ & 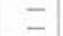 & $\underline{x}$ & $=$ & $\bar{z}$ & $=$ & \pm & $=$ \\
\hline $\begin{array}{l}\text { Sapphirina } \\
\text { spp. }\end{array}\left\{\begin{array}{l}\text { maculosa } \\
\text { sinuicauda } \\
\text { metallina }\end{array}\right.$ & & & & & & & & & & \\
\hline Sapphirina Opalina & $=$ & $\underline{x}$ & 0.06 & \pm 1 & $=$ & $=1$ & - & -1 & 0.2 & $=$ \\
\hline Euchaeta acuta & $=$ & $=$ & $=$ & $=$ & $\overline{-}$ & $=1$ & \pm 1 & -1 & \pm & \pm \\
\hline Leta major & -1 & -1 & -1 & -1 & -1 & -1 & $=$ & -1 & - & -1 \\
\hline Enchirella brevis & - & -1 & - & - & -1 & - & - & - & - & - \\
\hline irycaeus limbatus & -1 & - & -1 & - & -1 & - & - & - & - & - \\
\hline incaeus naccus & - & - & - & 0.07 & - & - & - & - & - & - \\
\hline $\begin{array}{l}\text { Corycaeus clausi } \\
\text { Copilia lata }\end{array}$ & $\Rightarrow$ & $x$ & - & $=$ & -1 & - & -1 & - & - & - \\
\hline $\begin{array}{l}\text { Copilia lata } \\
\text { Miracia efferata }\end{array}$ & $=$ & 二 & $=$ & $=$ & \pm & $=$ & 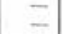 & $=$ & - & $=$ \\
\hline pphirella tropic & -1 & - & - & - & -1 & - & - & - & - & - \\
\hline tadrata & -1 & - & - & - & -1 & -1 & - & - & - & - \\
\hline Vrocorycaeus lautus & $\overline{-}$ & $\overline{-}$ & $=$ & - & $=1$ & -1 & - & $=$ & - & - \\
\hline & $=$ & $0 . \overline{6}$ & $=$ & $\therefore$ & $0 . \overline{4}$ & $\equiv$ & -1 & 二 & - & -1 \\
\hline $\begin{array}{l}\text { Haloptilus longic } \\
\text { Haloptilus spinice }\end{array}$ & $=$ & - & -1 & - & & - & - & $=$ & - & - \\
\hline Pontellina plumat & -1 & - & - & - & 0.2 & -1 & -1 & - & - & - \\
\hline Pontellopsis persy & -1 & - & - & $\ldots$ & 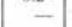 & -1 & - & - & - & - \\
\hline Pontellopsis villosa & - & - & -1 & - & - & -1 & - & - & -1 & - \\
\hline Candacia simplex & 0.5 & $\mathrm{x}$ & -1 & - & 0.4 & 0.5 & - & - & - & - \\
\hline $\begin{array}{l}\text { Candacia aethiopica } \\
\text { Euaugaptilus filiger }\end{array}$ & $\bar{z}$ & $3^{x}$ & -1 & -1 & $\mathbf{x}$ & -1 & $=$ & $=$ & $=1$ & $=$ \\
\hline $\begin{array}{l}\text { Euaugaptilus filiger } \\
\text { Calanoides carinatus }\end{array}$ & $1 . \overline{6}$ & - & -1 & - & $=$ & $=$ & $\Xi$ & $\mathrm{x}$ & \pm & $z$ \\
\hline $\begin{array}{l}\text { Eucalawus attenuatus } \\
\text { Sapphirina }\end{array}$ & - & - & - & - & $\mathrm{x}$ & 0.7 & - & - & -1 & - \\
\hline ovato-lanceolata & - & - & - & - & - & - & - & - & -1 & -1 \\
\hline Sapphirina nigromaculata & -1 & - & -1 & - & 0.4 & $=$ & - & $\overline{02}$ & $=$ & - \\
\hline Rhincalanus corni & 二 & 0.6 & $0 \overline{2}$ & $\bar{z}$ & -1 & & $\overline{0.7}$ & 0.2 & $\overline{11}$ & - \\
\hline $\begin{array}{l}\text { Centropages violace: } \\
\text { Neocalanus robustio }\end{array}$ & 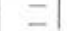 & 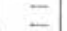 & 0.2 & 0.7 & $=$ & $=$ & 0.7 & $=$ & 1 & $=$ \\
\hline $\begin{array}{l}\text { Neocalanus robustioi } \\
\text { Sapphirina stellata }\end{array}$ & $=$ & $=$ & 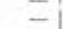 & $0 . \overline{13}$ & $0 . \overline{4}$ & -1 & & -1 & $\overline{0.2}$ & $=1$ \\
\hline Lubbockia squillima & - & 1.6 & - & - & - & - & -1 & - & - & 0.6 \\
\hline Corycaeus furcifer & - & - & - & - & - & -1 & -1 & - & - & -1 \\
\hline Corvcaeus typicus & - & 0.3 & - & - & 1.3 & 10 & 0.2 & - & 2.2 & -1 \\
\hline Heterorhabdus apinif & 0.5 & - & 0.05 & - & $0 \overline{7}$ & 1 & $\frac{1}{2}$ & $\overline{0-1}$ & - & $=$ \\
\hline $\begin{array}{l}\text { Candacia pach } \\
\text { Euchaeta mar }\end{array}$ & $=$ & - & $0 \overline{1}$ & 0.4 & 0.7 & 0.5 & $\begin{array}{l}2 \\
4\end{array}$ & 4 & $=1$ & .5 \\
\hline $\begin{array}{l}\text { a marina } \\
\text { tus gracilis }\end{array}$ & $=$ & 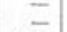 & & $\bar{z}$ & $1.4^{x}$ & -1 & 6 & $=$ & \pm & 1.2 \\
\hline Scolecithrix & 05 & 0.3 & 06 & 0.03 & & $x$ & $s$ & 2 & 2 & 2.4 \\
\hline Corycaeus speciosus & & - & & & 0.4 & 0.7 & & $\mathrm{x}$ & & 1.8 \\
\hline Acrocalanus & & 0.3 & 1.4 & & 0.4 & 0.1 & & $x$ & 2.7 & -1 \\
\hline Calocalanus pavo & - & - & - & 4 & & -1 & 6 & $\mathrm{x}$ & - & 0.6 \\
\hline $\begin{array}{l}\text { Mecynocera clausi } \\
\text { Acartia dange }\end{array}$ & - & 3.2 & 0.9 & & & $\underline{x}$ & -1 & - & 2 & - \\
\hline $\begin{array}{l}\text { Acartia danae } \\
\text { Corycaeus ovalis or latus }\end{array}$ & 1.1 & $\bar{z}$ & $0 . \overline{1}$ & & & $=$ & 4 & $=$ & \pm & 6 \\
\hline Nannocalanus minor & 2.2 & - & & & & 2] & i) & 7 & $x$ & \\
\hline Undinula vulgarix & $x$ & 1.2 & 1.7 & 2.1 & & 0.1 & 4 & 1.9 & 7 & -1 \\
\hline Copilia mirabilis & 0.5 & $x$ & 0 & - & & - & 4 & 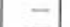 & 2 & - \\
\hline $\begin{array}{l}\text { Lucicutia flavicornis } \\
\text { Macrosetella }\end{array}$ & $0-$ & 2.2 & & 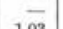 & & $\overline{1.1}$ & 1 & - & 1 & 11.8 \\
\hline $\begin{array}{l}\text { Macrosetella } \\
\text { Paracalanus a vuleatw }\end{array}$ & 0.5 & 1.6 & .4 & & - & 1.1 & & 2 & 1.3 & - \\
\hline Clauso & $=$ & $\bar{x}$ & & & 二 & 0.1 & $\begin{array}{c}6 \\
1\end{array}$ & -4.2 & 1.3 & $\div$ \\
\hline Corvellla gracilt & 15.71 & 7 & 31.0 & 6 & 7 & & & .22 .1 & 4.1 & 1 \\
\hline Clausocalanus fure & 52.2 & 22.6 & 31.0 & 59.2 & & 21.5 & 33.7 & 9.4 & 8.4 & -1 \\
\hline Oithona * & - & & - & & & - & & & & \\
\hline $\begin{array}{l}\text { Oncuea medi } \\
\text { Oncaea subt: }\end{array}$ & $\bar{z}$ & & 7.9 & 4.4 & 18.5 & $=$ & 21.8 & $\begin{array}{l}1 \\
8\end{array}$ & 27.0 & 9 \\
\hline $\begin{array}{l}\text { Oncaea venu. } \\
\text { Oncati }\end{array}$ & 0 & & 0 & $=$ & 2. & 6.1 & $\overline{0.5}$ & 28 & oes & $\overline{1.6}$ \\
\hline Oithona plum & & & & 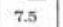 & & & 5 & & & \\
\hline sty & 10 & & 7. & & & 0. & 9 & 39.3 & & \\
\hline rechti & 2 & 1.2 & 4.3 & & 0.2 & -1 & 0.4 & - & 0.2 & 9.9 \\
\hline sta & - & & - & 0.03 & & 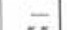 & - & $x$ & & $\pi$ \\
\hline c. & - & 13.53 & - & 0.03 & 5.1 & 5.5 & - & 8 & 0.2 & - \\
\hline Centropages & $x$ & $\bar{x}$ & 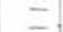 & - & $\bar{m}$ & - & -1 & 0.2 & - & - \\
\hline $\begin{array}{l}\text { Calocalan: } \\
\text { Acartia n }\end{array}$ & 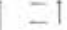 & t.or & $=1$ & $=1$ & & $=1$ & $=1$ & - & 2 & $=$ \\
\hline c & $\bar{x}$ & $=$ & $=$ & $=$ & 5 & -1 & - & Z & - & $=1$ \\
\hline Cor & 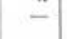 & - & - & $=$ & 0.7 & - & - & - & - & - \\
\hline & 1.6 & 1.6 & - & - & - & 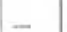 & 0.1 & - & - & 2 \\
\hline Pleurom & & & 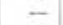 & 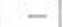 & 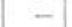 & - & 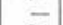 & 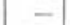 & 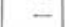 & \\
\hline & - & 6.7 & - & - & & & 0.1 & - & - & -1 \\
\hline & - & - & 1.1 & 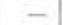 & & & & - & & 4 \\
\hline & - & - & - & - & - & & & - & - & 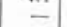 \\
\hline esbrer & - & - & - & - & & -1 & - & - & - & $=$ \\
\hline & - & - & - & - & - & -1 & 1.9 & - & - & - \\
\hline & - & - & - & 0.03 & 2.6 & $\mathrm{x}$ & - & - & - & - \\
\hline & - & - & - & - & 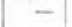 & - & - & - & - & 1.2 \\
\hline $\begin{array}{l}\text { Lueicu } \\
\text { Aeghis }\end{array}$ & - & - & - & $\overline{-}$ & - & -1 & & - & $\overline{-}$ & $=$ \\
\hline s. & & - & - & 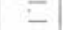 & & & 1.8 & - & - & - \\
\hline & & $x$ & - & - & & - & - & 1.2 & - & 1.2 \\
\hline & - & - & - & - & - & 0.9 & 0.1 & 2 & - & 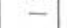 \\
\hline & 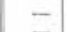 & - & - & 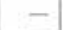 & & 1 & & $\overline{0}$ & - & - \\
\hline $\begin{array}{l}\text { Pontel } \\
\text { Coryco }\end{array}$ & $\overline{-}$ & $\bar{x}$ & $\overline{-}$ & 二 & - & $\overline{-}$ & $\underline{0.1}$ & 0.9 & $\overline{-}$ & $\bar{z}$ \\
\hline апะ. & - & - & & I & $=1$ & $E$ & $=$ & $=$ & $=$ & E \\
\hline & - & -1 & 0.05 & - & -1 & - & - & - & -1 & 1.8 \\
\hline & - & - & - & - & - & - & - & - & - & - \\
\hline , & - & & - & $=$ & - & - & - & -1 & - & - \\
\hline ranea & - & & & - & 2.4 & - & & -1 & & 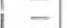 \\
\hline & & 5.1 & - & - & & -1 & -1 & -1 & - & - \\
\hline ona & - & - & - & - & - & 5.5 & - & -1 & - & - \\
\hline tella & & $\rightarrow$ & -1 & -1 & $\mathrm{x}$ & 1 & - & - & - & - \\
\hline
\end{tabular}

$x=$ Presence of the specles in the total sample but not in the sub-sample. 


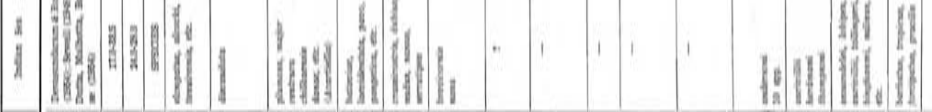

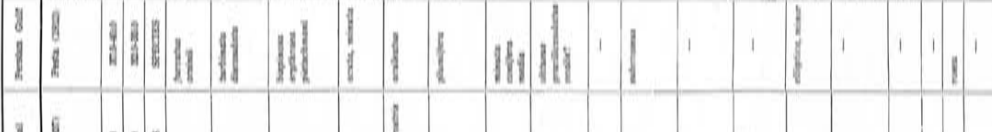

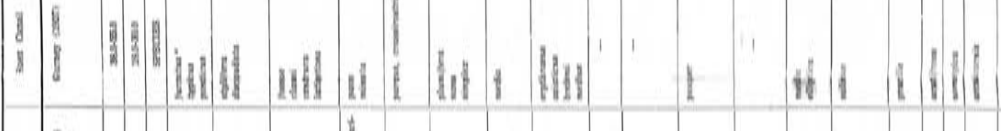

4. In:

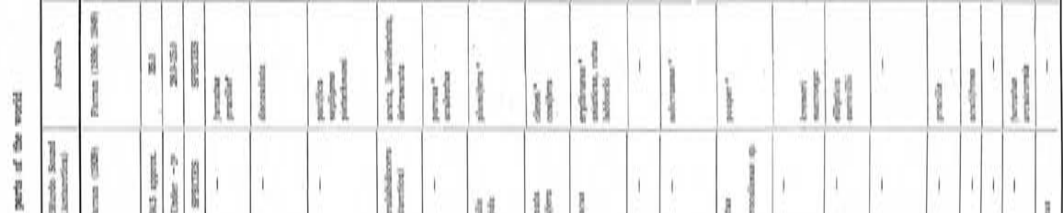

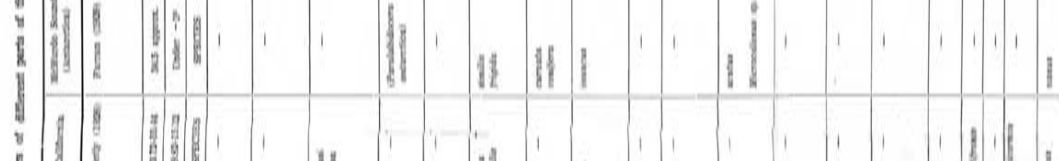

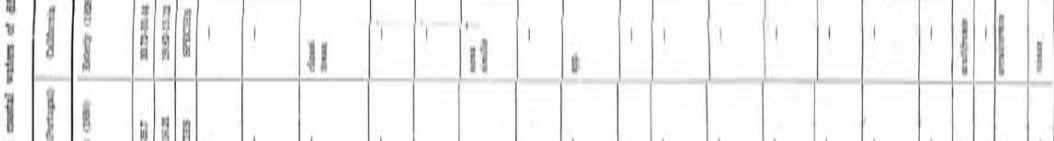

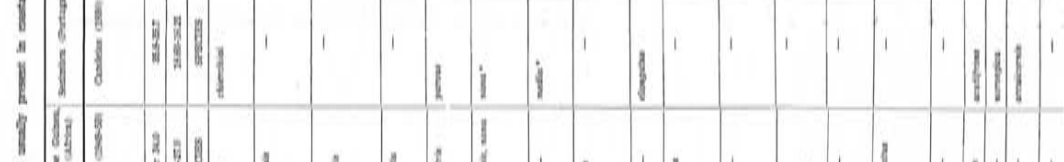

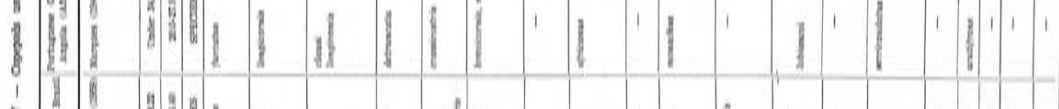

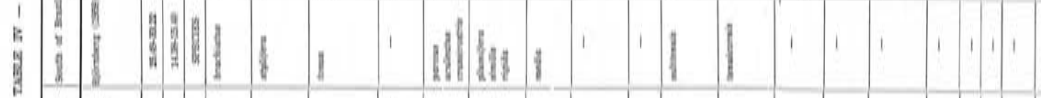

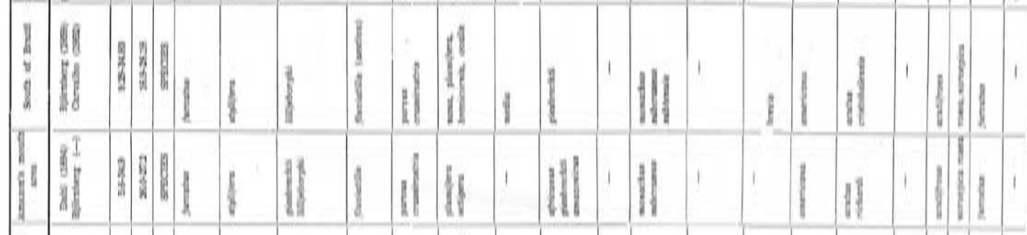
iil II 3 an 1 . 1 .

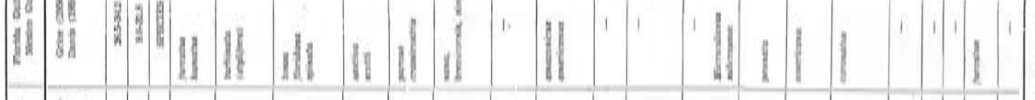

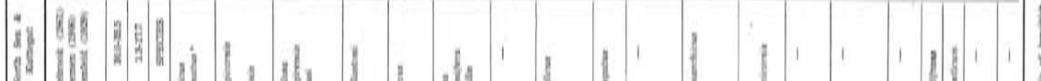

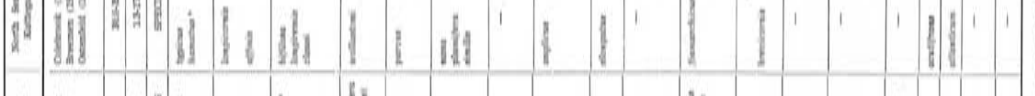

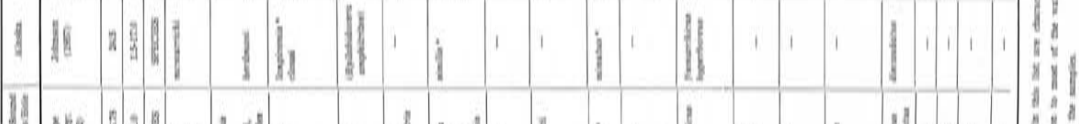

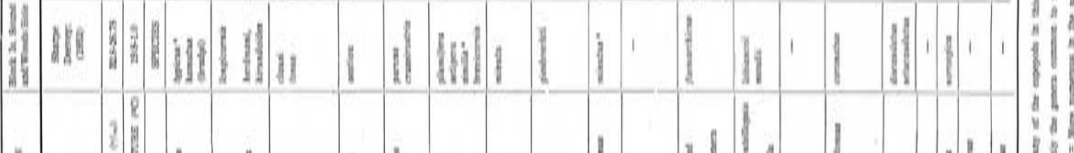

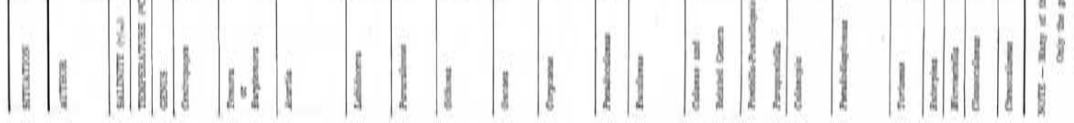




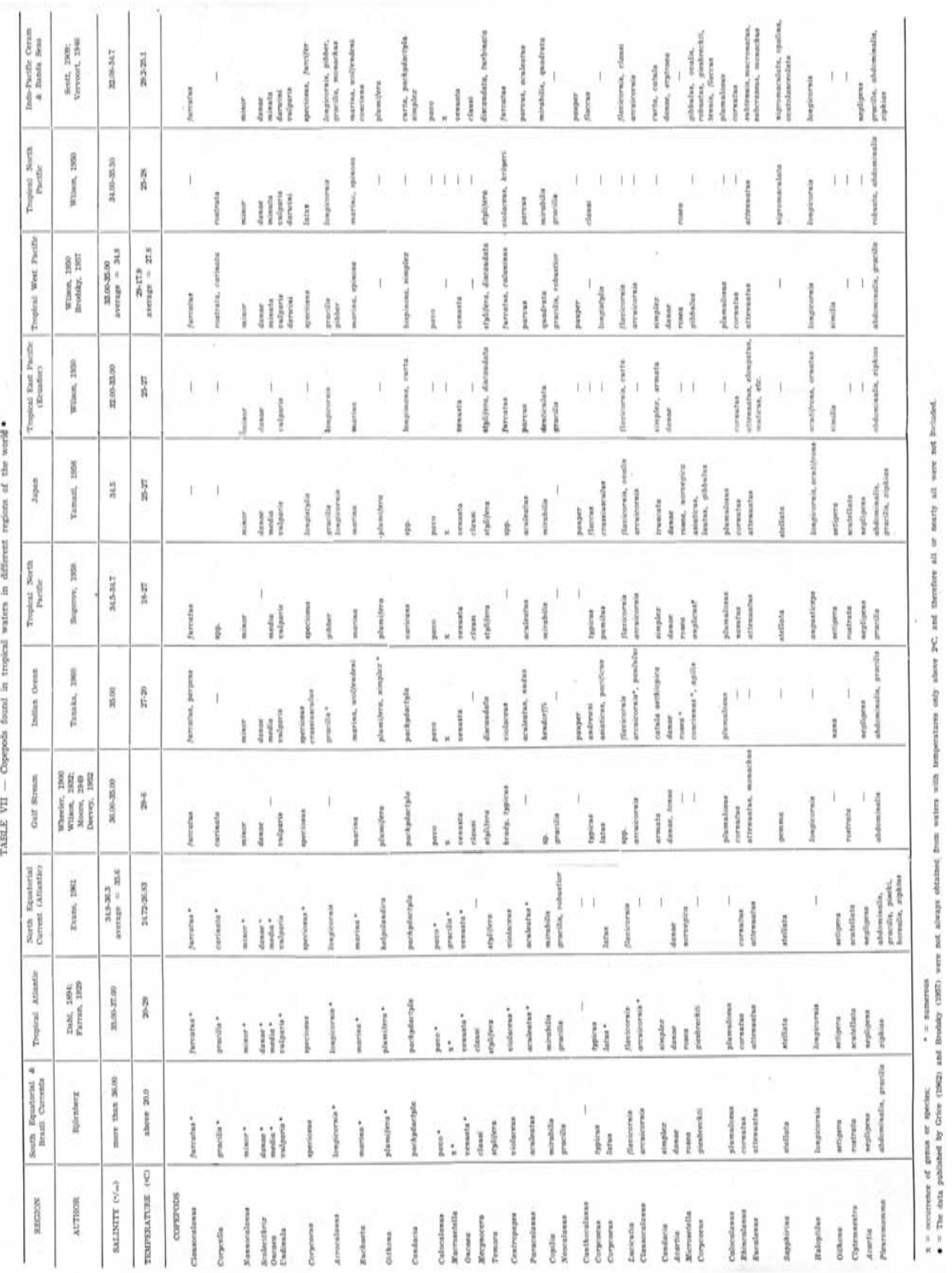


1929) ; 2 - the same characteristic association with minor variations on the species level can be expected in waters from other parts of the world where the same temperature and salinity ranges as in Brazilian tropical waters are observed.

\section{SUBTROPICAL SURFACE WATERS}

As the Brazil Current advances southwards it diminishes in strength and in winter its southern boundary is not always clearly discernible (Emilsson 1959, p. 49). The tropical water gradually looses its high temperature in the subtropical region by admixture with surrounding water and contributes in the south of Brazil to the formation of water with salinities around $36.00 \%$ and temperatures of $18^{\circ} \mathrm{C}$ or less, in the surface layer (Table IX). Plankton volumes of samples from this water averaged $0.08 \mathrm{ml} / \mathrm{m}^{3}$, the poorest of the waters studied. Dominant in volume in these waters are Pleuromamma, Nannocalanus minor and Clausocalanus furcatus or C. arcuicornis, Oncaea venusta and Acartia. In these impoverished waters, Corycella rostrata sometimes in high percentages, substitutes Corycella gracilis or Corycaeus giesbrechti of other waters. The following copepods were present in the 11 samples examined from these waters: Mecynocera clausi (in higher percentages) and Scolecithrix sp., in lower percentages than in tropical waters. Clausocalanus furcatus was present in high percentages in 9 out of 11 samples. Clausocalanus arcuicornis, in 6 out of 11 samples, in higher percentages sometimes than C. furcatus. Nannocalanus minor, Calocalanus pavo, Euchaeta marina, Macrosetella were also frequent. Nannocalanus minor appears in percentages as high as $\mathbf{1 6 . 7}$ of the total number of copepods per sample.

In the surface subtropical waters only 68 species were recorded off Brazil (Table VIII). Some species of the same genus prefer the warmer and others these colder waters as already pointed out for Corycella and Clausocalanus. Candacia aethiopica is found more frequently than $C$. pachydactyla in this environment, Euchaeta acuta is also found sometimes, instead of E. marina. The genus best represented in this water is Pleuromamma with its four species, $P$. gracilis (and its variety $P$. piseki), $P$. abdominalis, $P$. xiphias and $P$. borealis. The study of waters from other regions with salinities above $35.5 \%$ and temperatures between $20^{\circ}$ and $16^{\circ} \mathrm{C}$ show a similar composition of copepod species. In all these regions the great number of Mecynocera clausi, of Clausocalanus arcuicornis, Nannocalanus sp. and Pleuromamma spp. was directly observed (Table X). 


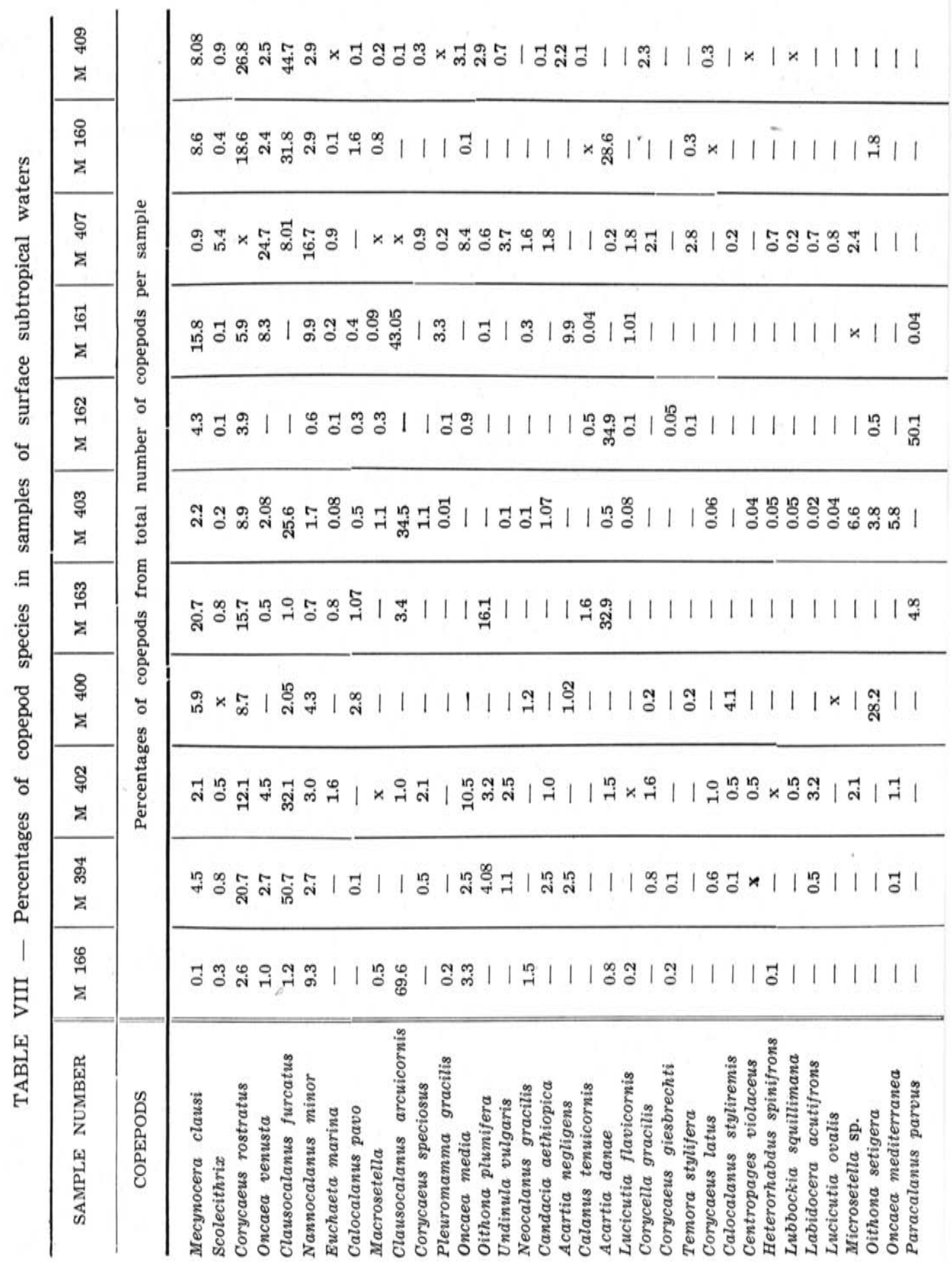


| | | | | 궁 | | | | | | * | | | | | | | | | | | | | | 영 | | | | | | |

$|1| 1|1| 1|1: 1| 1|1| 1|1| 1|1| 1|1| 1|1| 1$

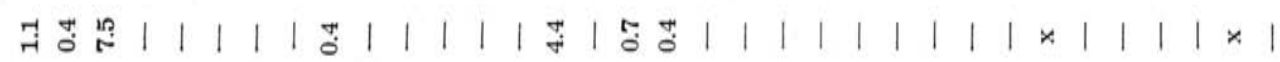

| | | | : \&

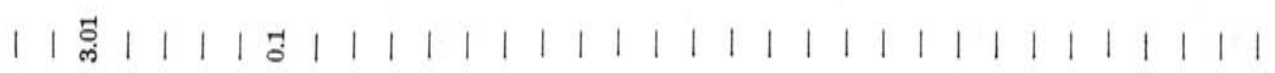

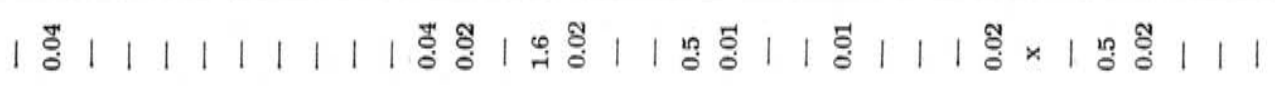

| | | \% | | | | | | | | | | | | | | | | | m | | | | | | \% | | | | |

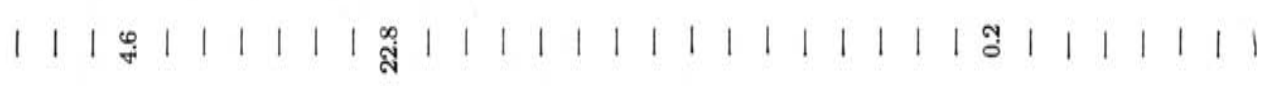

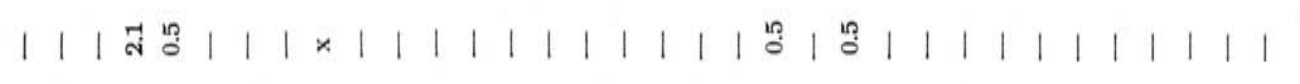

||||$|\stackrel{g}{g}|$ |

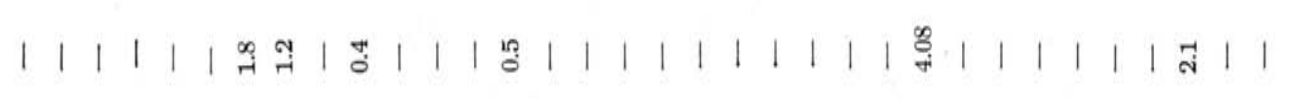

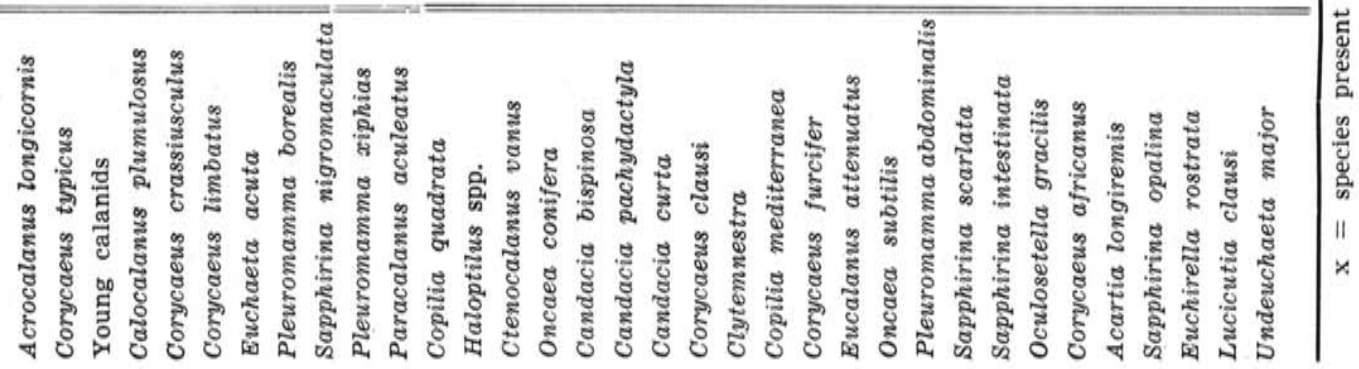




\begin{tabular}{|c|c|c|c|c|c|c|}
\hline 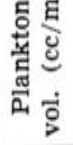 & 1 & 명 & \% & $\stackrel{\text { ஜ }}{0}$ & 1 & $\begin{array}{l}\text { ॠ } \\
\text { त్ }\end{array}$ \\
\hline $\begin{array}{l}\overleftrightarrow{\mathrm{u}} \\
\mathrm{z}\end{array}$ & is & สิ & ลิ & สิ & in & సิ \\
\hline 蜻 & 송 & 出蒋 & $\begin{array}{r}\text { E } \\
>0 \\
\text { E }\end{array}$ & 生沾 & $\begin{array}{l}\text { E } \\
\text { फ⿱ } \\
0\end{array}$ & $>\frac{E}{\stackrel{1}{+}}$ \\
\hline 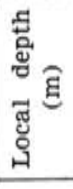 & $\begin{array}{l}\text { \&े } \\
\text { i⿱ } \\
\text { 2\|I }\end{array}$ & ॠ & 慧 & 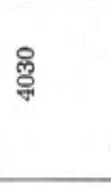 & $\begin{array}{l}\text { \&్ } \\
\text { ळ్ } \\
\text { ?\|l }\end{array}$ & 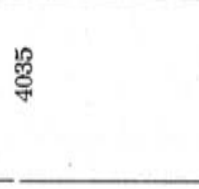 \\
\hline 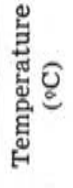 & 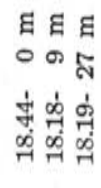 & 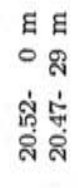 & 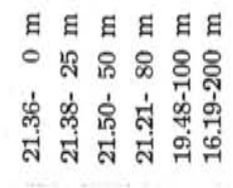 & 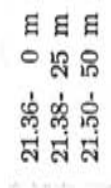 & 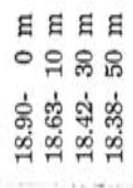 & 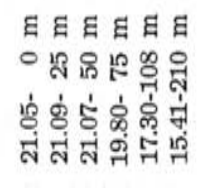 \\
\hline 莺 & 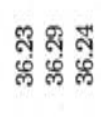 & 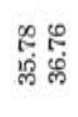 & 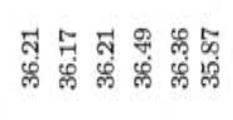 & 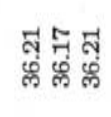 & 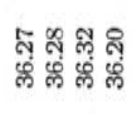 & 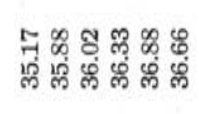 \\
\hline 芯 & 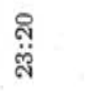 & $\begin{array}{l}\stackrel{8}{\ddot{~}} \\
\ddot{\oplus}\end{array}$ & 1 & 1 & $\stackrel{\stackrel{+!}{\square}}{\ddot{\sigma}}$ & 1 \\
\hline ڤัّ & 点 & $\frac{i \rho}{7}$ & $\begin{array}{l}\text { in } \\
\text { मे } \\
\text { के }\end{array}$ & 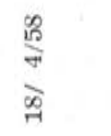 & 员 & 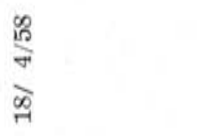 \\
\hline $\begin{array}{c}\text { Бే } \\
\stackrel{\Xi}{0} \\
0 \\
0\end{array}$ & 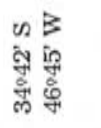 & 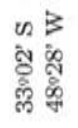 & 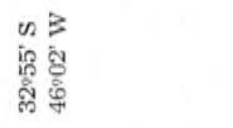 & 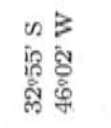 & 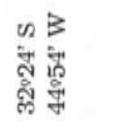 & 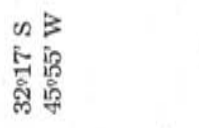 \\
\hline 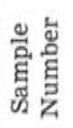 & 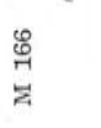 & 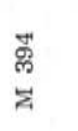 & 帝 & 兽 & 隽 & $\begin{array}{l}\text { ֻ } \\
\stackrel{4}{a}\end{array}$ \\
\hline
\end{tabular}




\begin{tabular}{|c|c|c|c|c|}
\hline 1 & 1 & 궁 & 1 & ণั \\
\hline Un & $n$ & สิ & Us & สิ \\
\hline $\begin{array}{l}\text { : } \\
\text { 둥 } \\
0\end{array}$ & ⿷匚 & 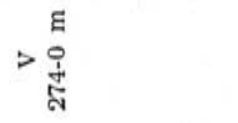 & $\begin{array}{l}\text { E } \\
\text { ధุ } \\
\vdots\end{array}$ & 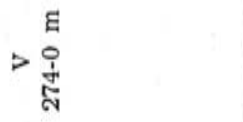 \\
\hline 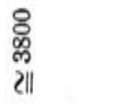 & 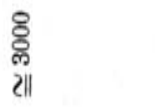 & $\begin{array}{l}\text { ¿ } \\
\text { ¿্ল }\end{array}$ & 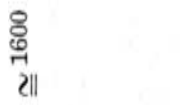 & 导 \\
\hline 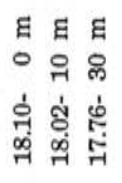 & 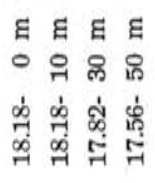 & 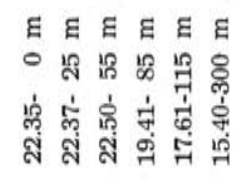 & 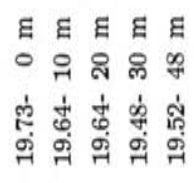 & 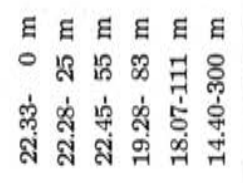 \\
\hline 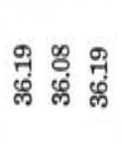 & 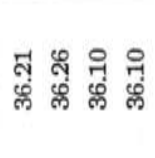 & 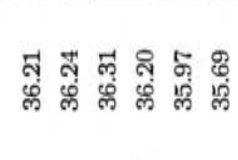 & 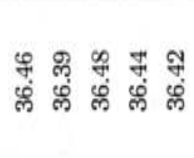 & 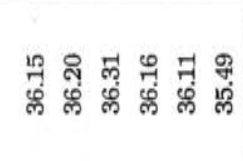 \\
\hline$\stackrel{\text { 윰 }}{\ddot{\ddot{g}}}$ & 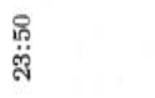 & 1 & 吕 & 1 \\
\hline 点 & 号 & के & $\underbrace{\frac{1}{6}}_{6}$ & 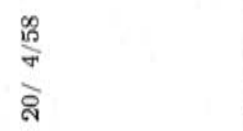 \\
\hline 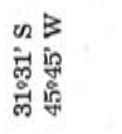 & 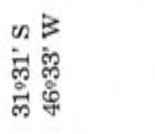 & 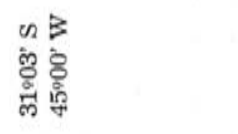 & 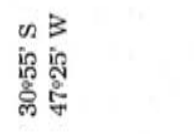 & 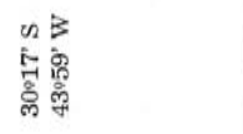 \\
\hline થ્ఝ & 흄 & $\stackrel{5}{5}$ & Ð & 宗 \\
\hline$\Sigma$ & 충 & $\ddot{z}$ & $\bar{z}$ & $\bar{z}$ \\
\hline
\end{tabular}




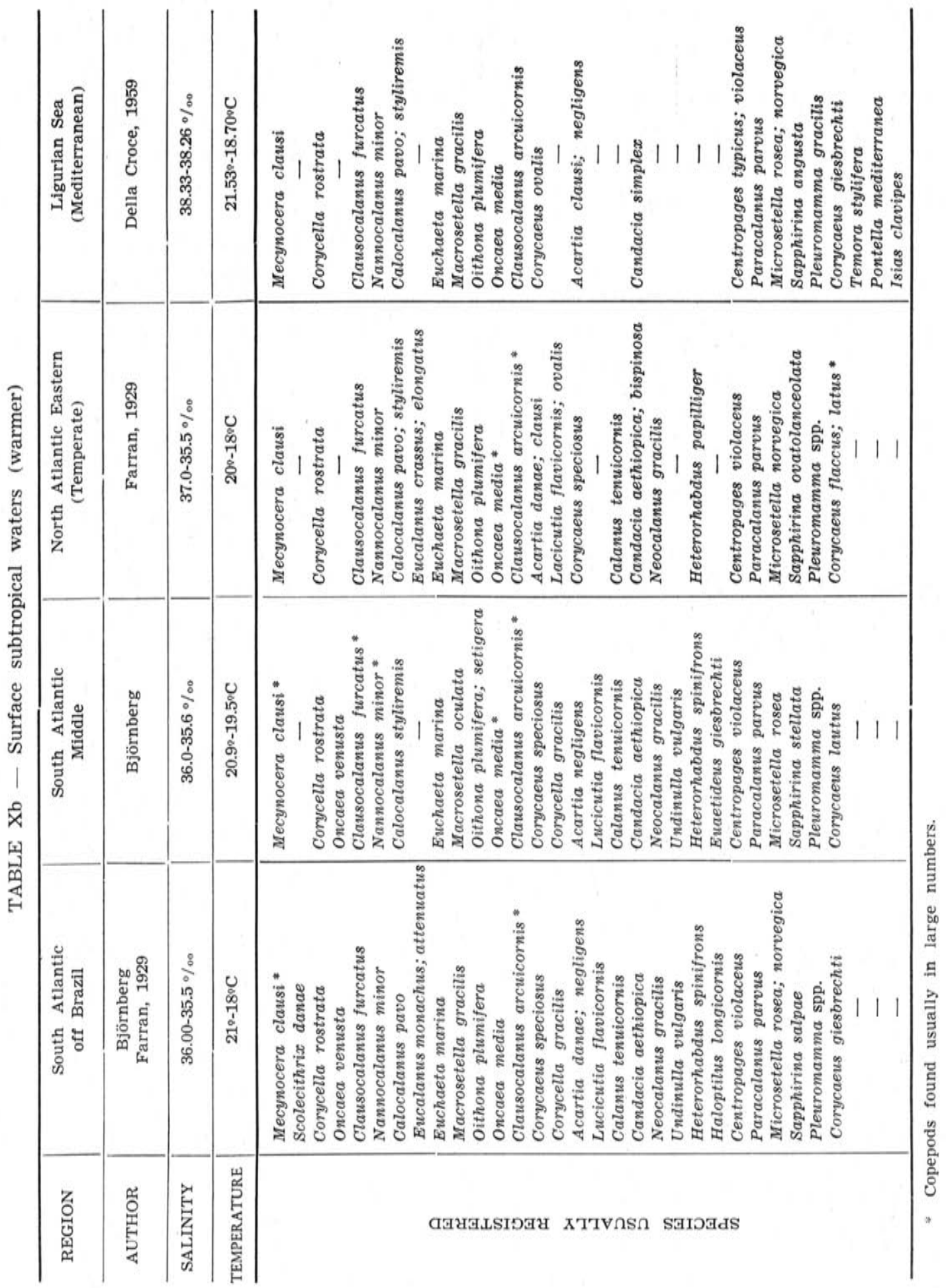


S H E L F W A T E R

Surface shelf waters - Over the continental shelf, in a parallel band along the coast from $24^{\circ} \mathrm{S}$ to $27^{\circ} \mathrm{S}$ there is a layer of water which is the result of mixture of subtropical or deep shelf water and coastal water. It is heated locally and also suffers the influence of the surface tropical water (Emilsson 1959, p. 49-53). This water is here called "surface shelf water" or "warm shelf water" because its temperature is usually above $20^{\circ} \mathrm{C}$, while the temperature of the "deeper shelf water" is usually under $20^{\circ} \mathrm{C}$. Thirteen samples (Table XI) taken in layers chiefly of this water contained the following copepods in more than 6 samples: Temora stylifera, Centropages furcatus, Corycaeus giesbrechti, Oncaea media, Calanopia americana, Paracalanus aculeatus, Clausocalanus furcatus, Copilia mirabilis, Oithona plumifera, Eucalanus subcrassus in a decreasing order of frequency. Nannocalanus minor, Undinula vulgaris, Pontellopsis brevis and Macrosetella occurred in five of the examined samples. Any of the species characteristic of other water masses may occur in these waters because this is the result of mixture of the other waters (Table XIII). Seventy species were found in these waters, 39 of which appeared in one of the samples.

Table XVII compares our copepod list for shelf waters with those of other areas in the Atlantic and in the Pacific where approximately the same conditions of temperature and salinity occur. Fleminger (1959, p. 154) finds three different facies on the North American shelf, which are named and characterized as follows: 1 - coastal-neritic, where Centropages furcatus and Temora turbinata dominate; 2 - neritic-slope, characterized by Eucalanus pileatus and Paracalanus parvus; 3 - oceanic-shelf with Clausocalanus furcatus and Undinula vulgaris.

Bainbridge (1960, tab. 1) off Africa (from River Volta to Lagos) found the following association in waters over the continental shelf with salinity usually over $35.00 \%$ and temperatures usually over $23^{\circ} \mathrm{C}$ (personal information): Temora turbinata, Oncaea venusta, Corycaeus giesbrechti, Temora stylifera, Centropages furcatus, Euchaeta marina, Eucalanus monachus, Centropages chierchiai, E. pileatus, Paracalanus parvus, etc., in a decreasing order of numbers.

The same facies could be pointed out for our shelf waters, according to the greater influence which they may suffer from coastal deep shelf or from oceanic (Brazil Current) waters. $\mathrm{Te}$ - 


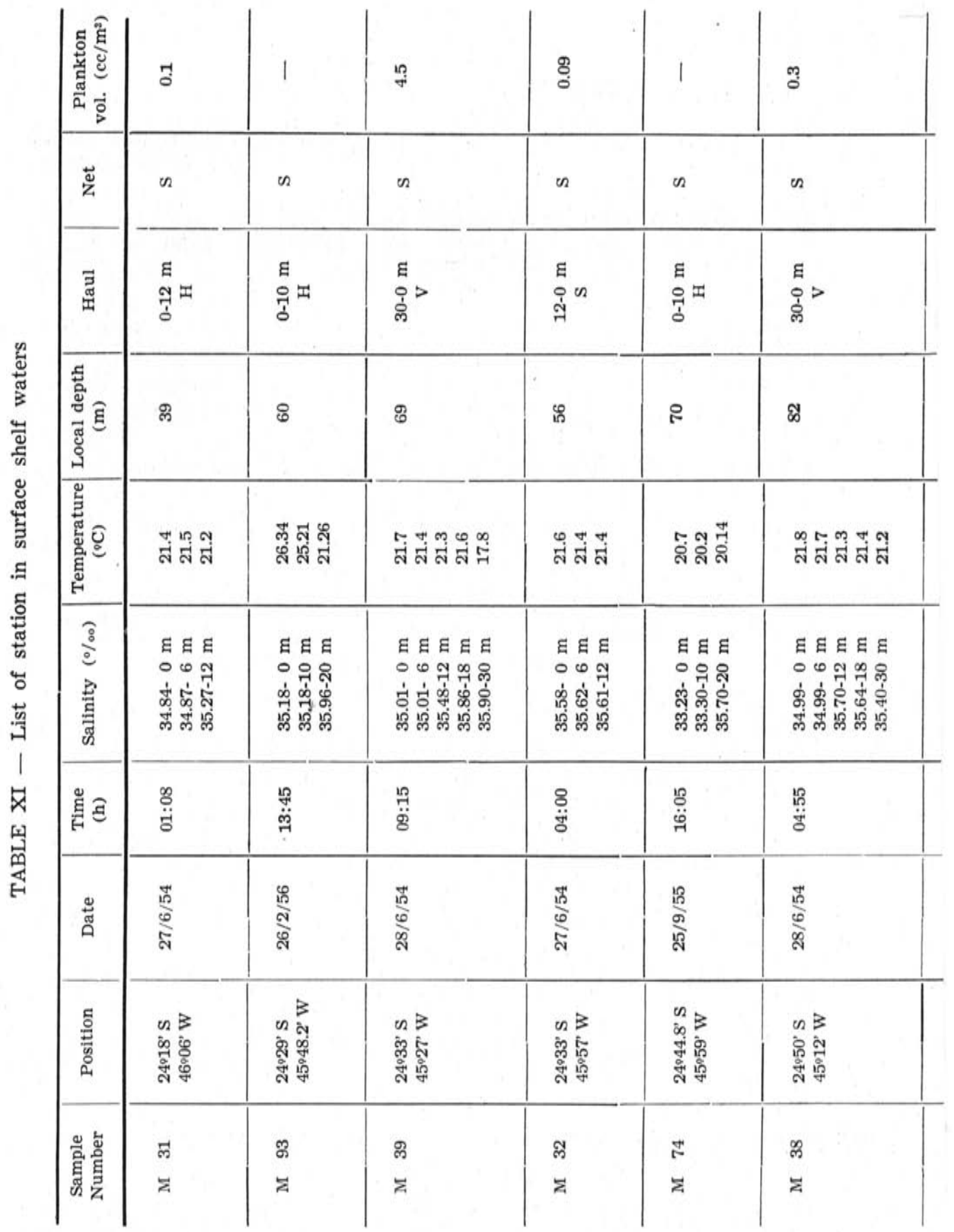




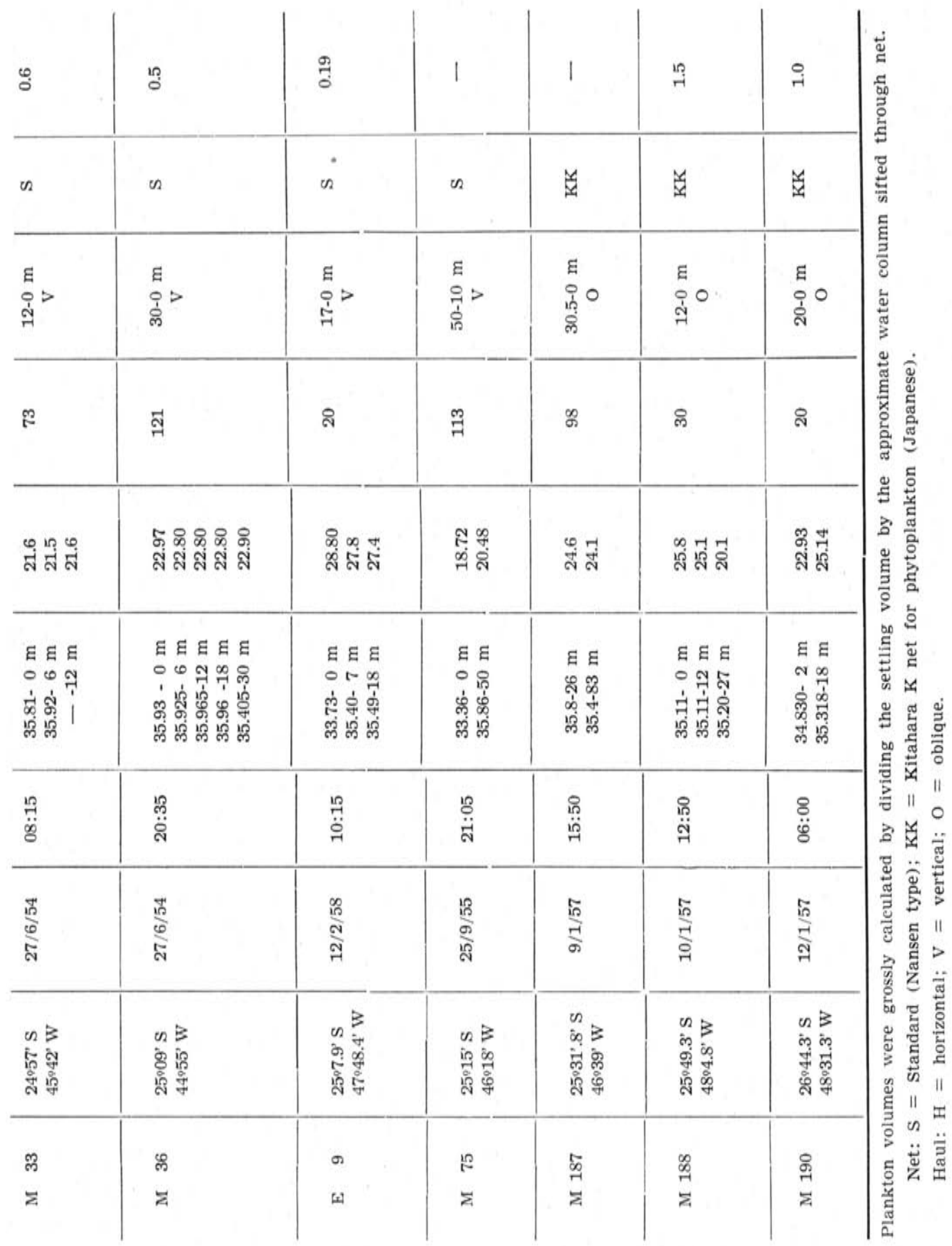




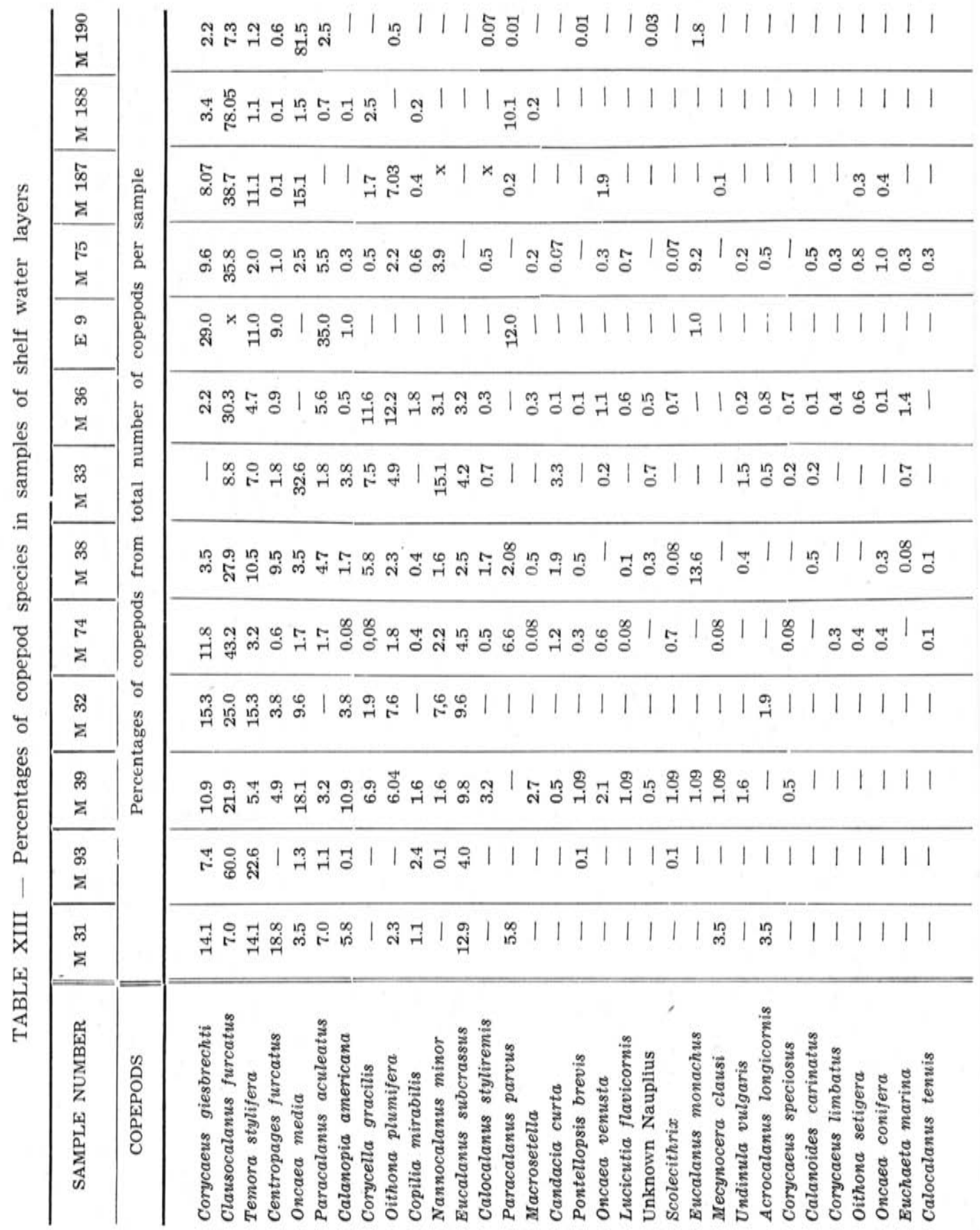


TABLE XII - Copepods found in the gastric contents of fishes caught off Cananéia and off Santos

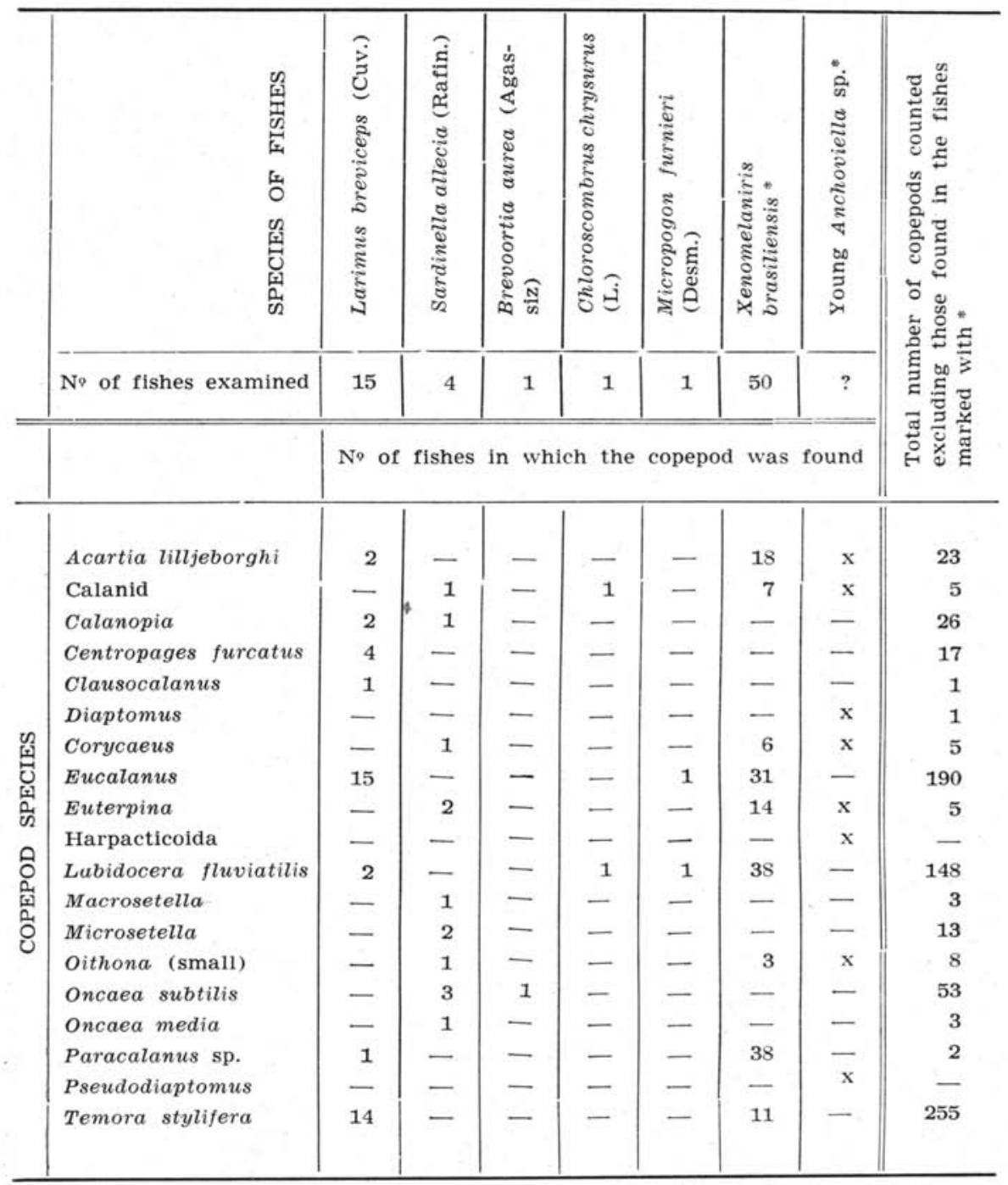

- These data were taken from unpublished notes by J. Paiva Carvalho. $\mathrm{x}=$ Number of fishes unknown. 
mora stylifera, Eucalanus subcrassus or monachus and Paracalanus aculeatus are the species which occur off Brazil instead of Temora turbinata, Eucalanus pileatus and Paracalanus parvus. Our data may also be compared to those of Pierce $(1953$, p. 88) and of Moore $(1958$, p. 165, figs. 5, 39) who also found a shelf water environment off the northwestern Atlantic coast where there are an "inner shelf zone" or "coastal water", an "outer shelf zone" or "slope water". These authors do not mention the deeper shelf water environment which is present off the Brazilian and African coasts.

Deeper shelf waters - The deep waters (Table XIV) on the shelf are probably derived from deep subtropical water which, because of its greater density sinks and moves slowly underneath the Brazil Current in opposite direction.along the border of the shelf (Emilsson 1959, p. 46, 49-50). In these waters Ctenocalanus vanus is the characteristic copepod, usually occurring in dominant numbers and volume (Table XV). This widespread species is found in largest number in the cold Antarctic surface coastal waters (Farran 1929, p. 226) but it occurs even in tropical regions, though in deeper layers (Vervoort 1951, p. 51-61) which makes it probable that it was introduced in this region by the cold Falkland Current mixed with the subtropical water. Ctenocalanus vanus is found in surface waters of temperatures under $16^{\circ} \mathrm{C}$ and in salinities between 34.00 and $35.5 \%$. In deeper waters it is found in temperatures up to $20^{\circ} \mathrm{C}$. Calanoides carinatus may also appear in large numbers and volume in these samples. The neritic influence on this water is indicated by the presence of Corycaeus giesbrechti and Oncaea media, in 12 out of 13 samples examined; of Centropages furcatus in 8 out of 13 samples; of Temora stylifera, in 11 out of 13 samples. Oithona plumifera, Paracalanus parvus (in large numbers) and Eucalanus subcrassus occurred in 8 or 9 out of 13 samples. Clausocalanus furcatus, Corycaeus gracilis, Mecynocera clausi, Calanus tenuicornis and Paracalanus aculeatus occurred less frequently (in 7 to 5 samples out of 13). Their presence is perhaps due to the origin of these waters by ressurgence from deeper layers. The neritic influence is strong here too as is also shown by its richness in plankton volume (more than $\left.1.0 \mathrm{ml} / \mathrm{m}^{3}\right)$. Along and off the slope of the continental shelf the deep subtropical waters are poorer (Vannucci \& Almeida Prado 1959, tab. II; Vannucci, unpublished data). Waters with salinities ranging between 35.00 and $36.00 \%$ in the North Atlantic and with temperatures between 10 and $17^{\circ} \mathrm{C}$ are called "intermediate" or "mixed" waters (Kusmorskaya 1960, p. 147; Kanaeva 


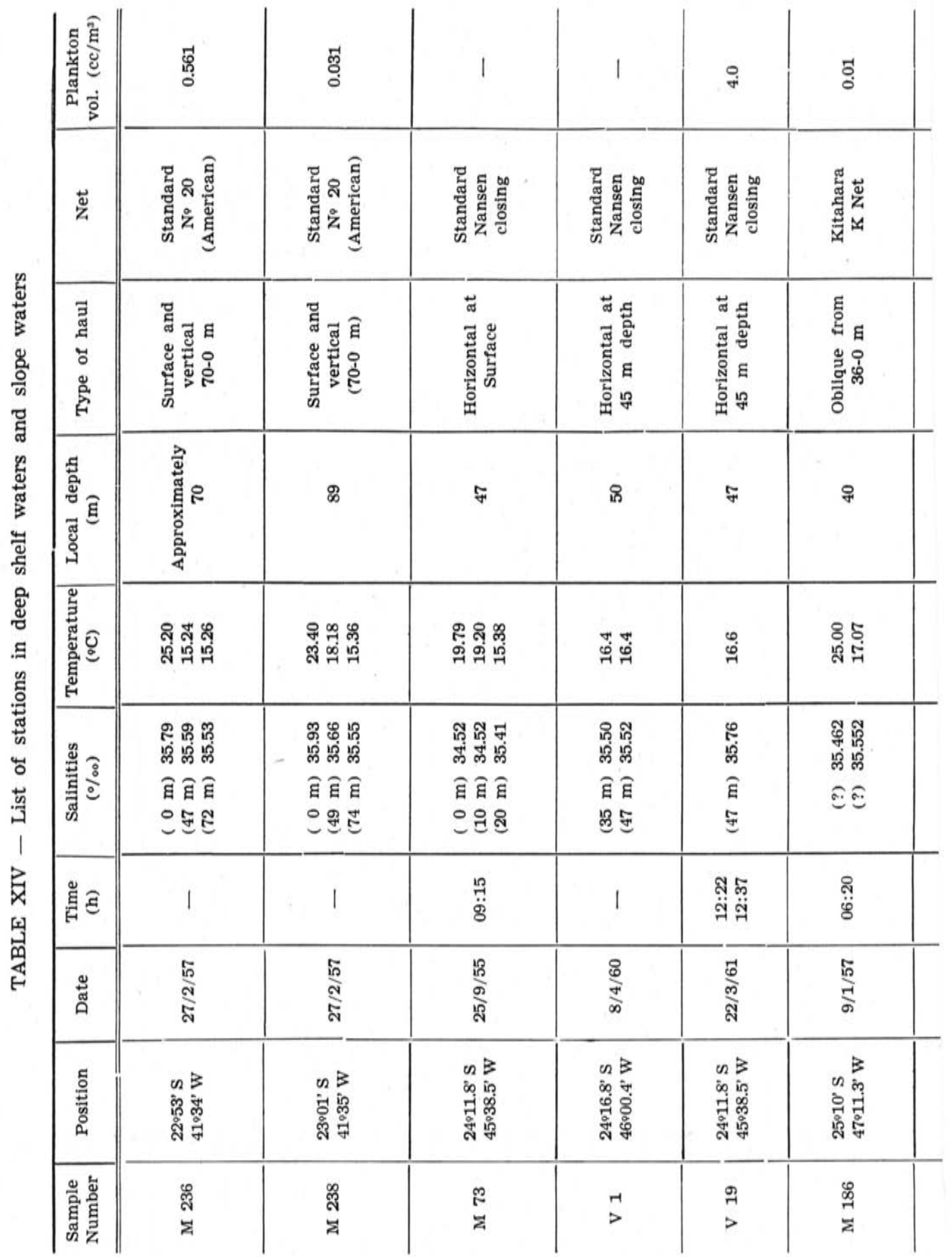




\begin{tabular}{|c|c|c|c|c|c|c|}
\hline 궁 & $\stackrel{\infty}{\stackrel{\infty}{0}}$ & స్ & 1 & $\stackrel{\text { ¿̊ }}{\circ}$ & ભุ & ศุ \\
\hline 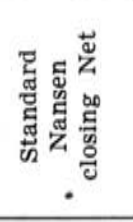 & 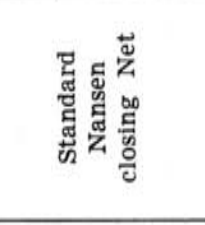 & 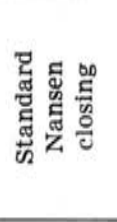 & 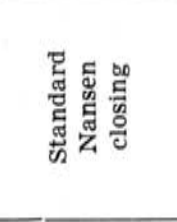 & 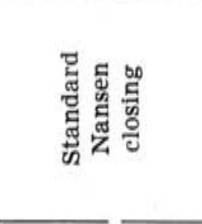 & 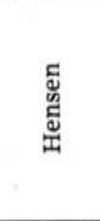 & 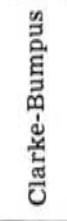 \\
\hline 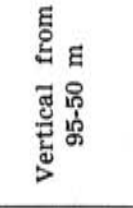 & 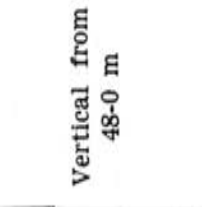 & 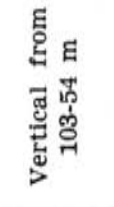 & 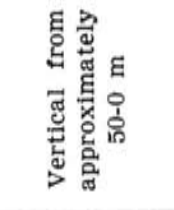 & 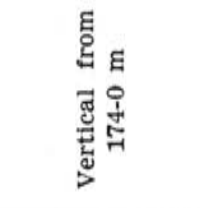 & 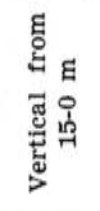 & 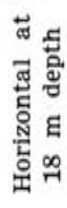 \\
\hline$\stackrel{9}{7}$ & $\underset{7}{\stackrel{2}{2}}$ & ำ & ది & $\begin{array}{l}\infty \\
\text { ले } \\
\text { m }\end{array}$ & 요 & $\stackrel{-}{\rightarrow}$ \\
\hline 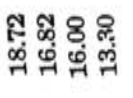 & 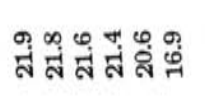 & 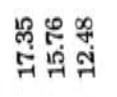 & 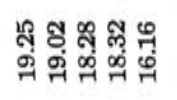 & 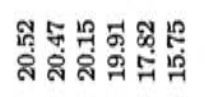 & 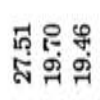 & $\stackrel{\varphi}{\stackrel{9}{7}}$ \\
\hline 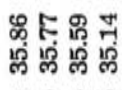 & 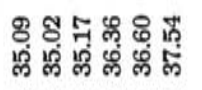 & 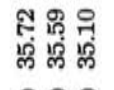 & 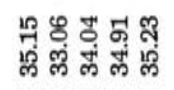 & 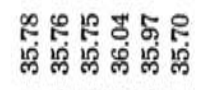 & 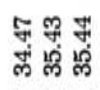 & 藏 \\
\hline 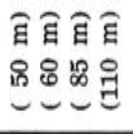 & 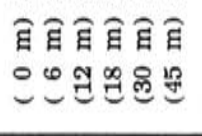 & 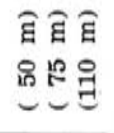 & 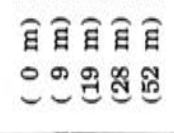 & 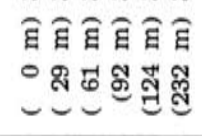 & 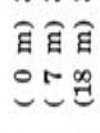 & \\
\hline $\begin{array}{l}\text { 吊 } \\
\text { ลิ่ }\end{array}$ & 婴 & 导 & 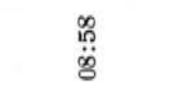 & 1 & 苚 & 号嵒 \\
\hline$\frac{p_{0}^{\circ}}{\frac{2}{2}}$ & $\frac{\text { है }}{\text { है }}$ & 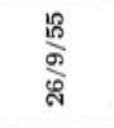 & है & 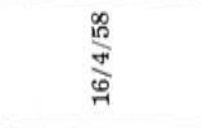 & 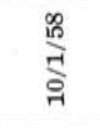 & 总 \\
\hline 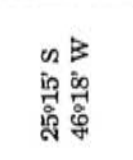 & 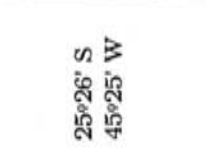 & 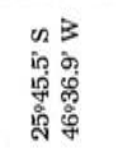 & 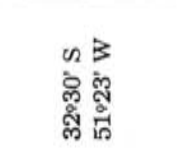 & 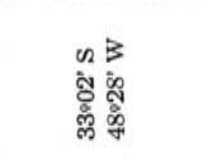 & 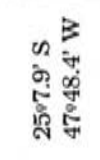 & 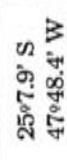 \\
\hline $\begin{array}{l}\mathscr{2} \\
2\end{array}$ & 鬲 & $\stackrel{\infty}{2}$ & 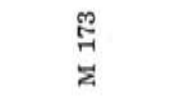 & 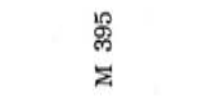 & tra & $\begin{array}{l}\text { N } \\
\text { 田 }\end{array}$ \\
\hline
\end{tabular}




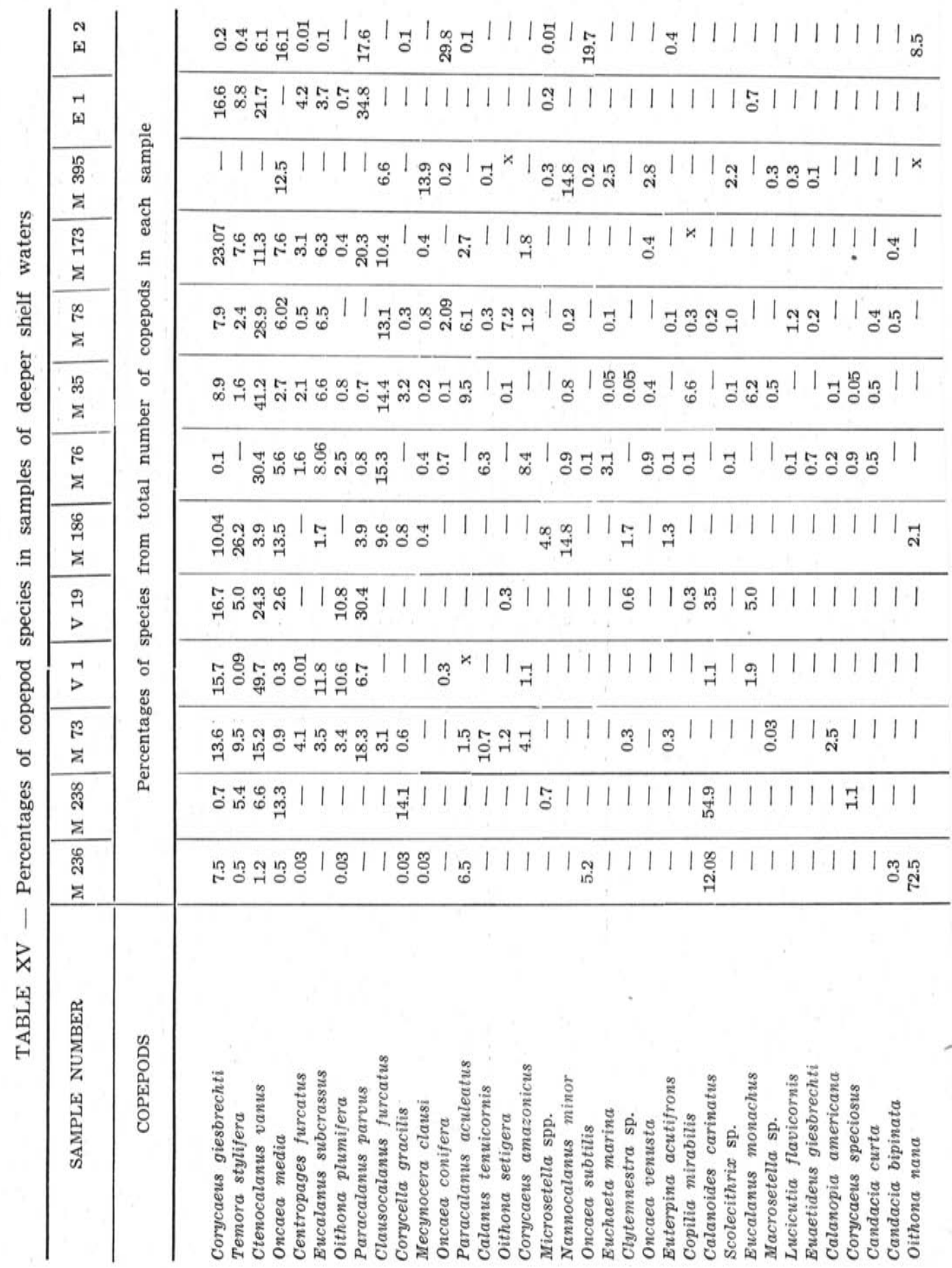


111111111111111111111111111111111111000000

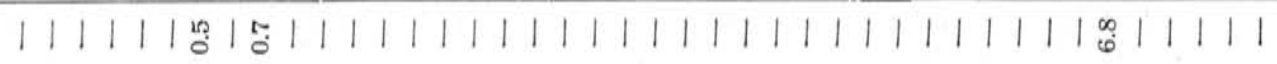

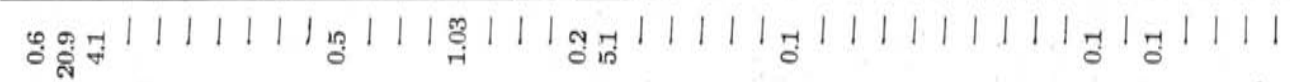
1111111111111 1111111111111111111111111111

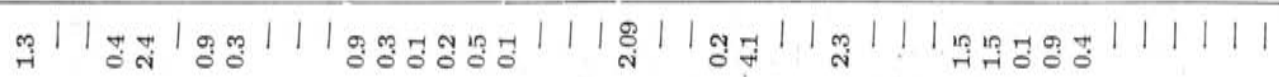

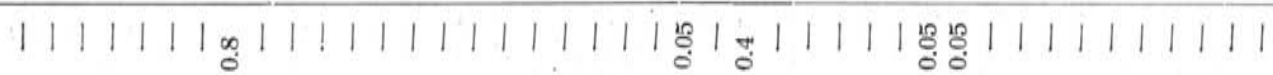

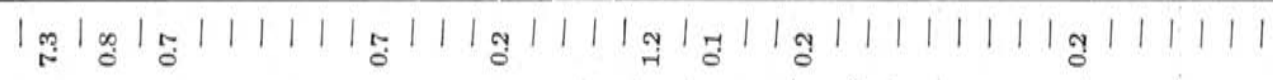

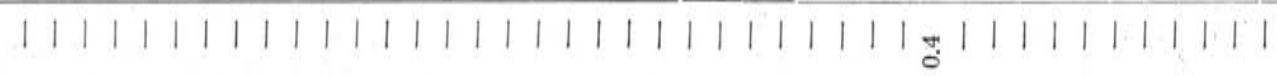
11111111111111111111111111111111111111111

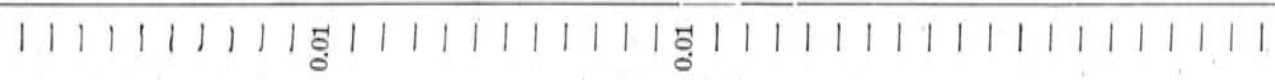

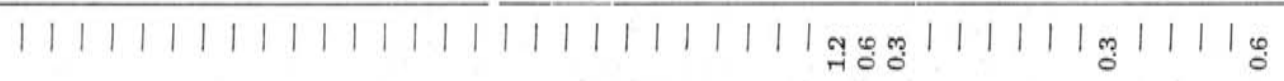

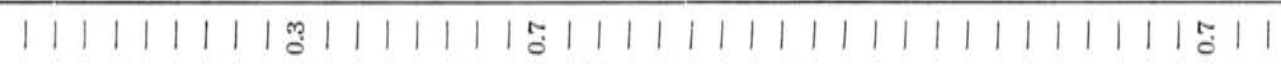

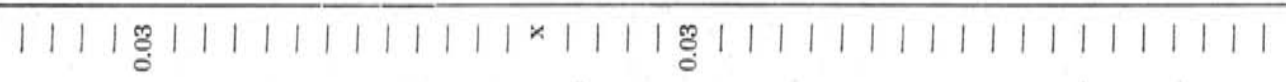

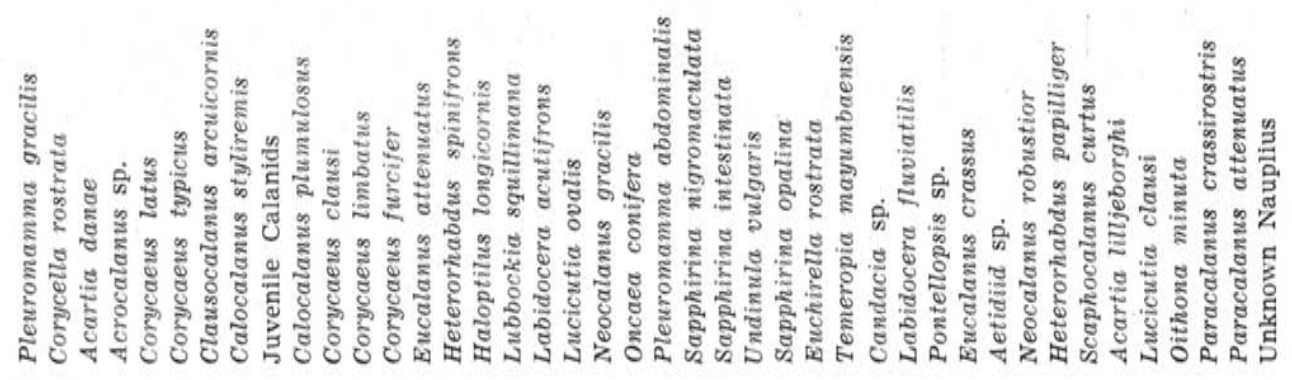




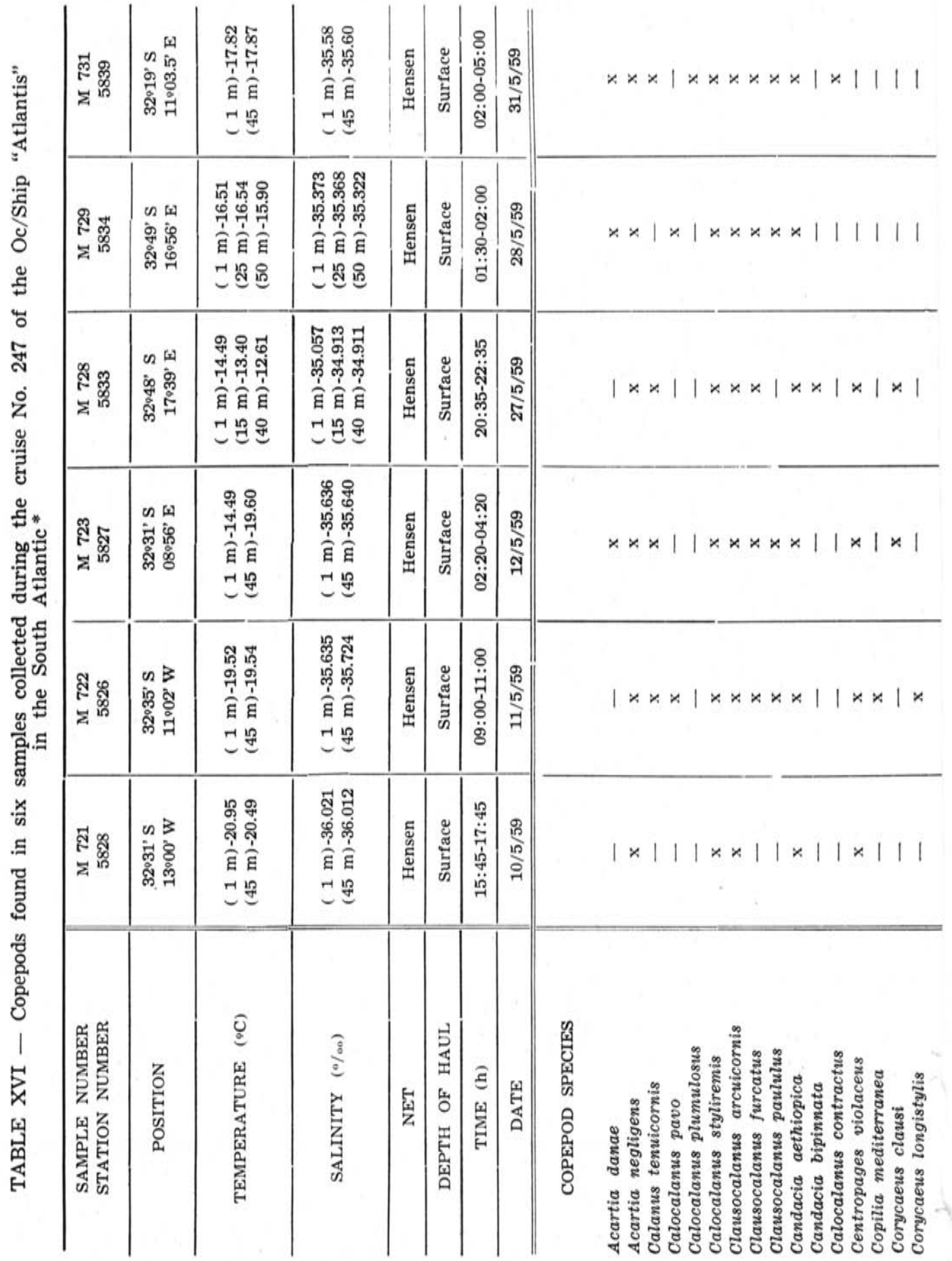


||$x * x *|||x * x||x * x * \tilde{x} * x * x * \ldots *| x * x *|||||x|$

||||||$x|||| x \ddot{x}|x|||+x|||x| \ddot{x} \times|||| x|| \mid$

$|x \times||x||x| x|| x \times x \times|a| x|x||| x|||x||x| \mid$

$x \times x \times x|\times x| \times|\times||x \times x||\times a \times x a x \times x \times||x||| \mid x$

$x \times x \times x|x||||x||| x x|\ddot{x} \times||x| x|||||| x|| \mid x$

$x x x \times x|||x||x||||x x x||| x x x|||||||||| x$

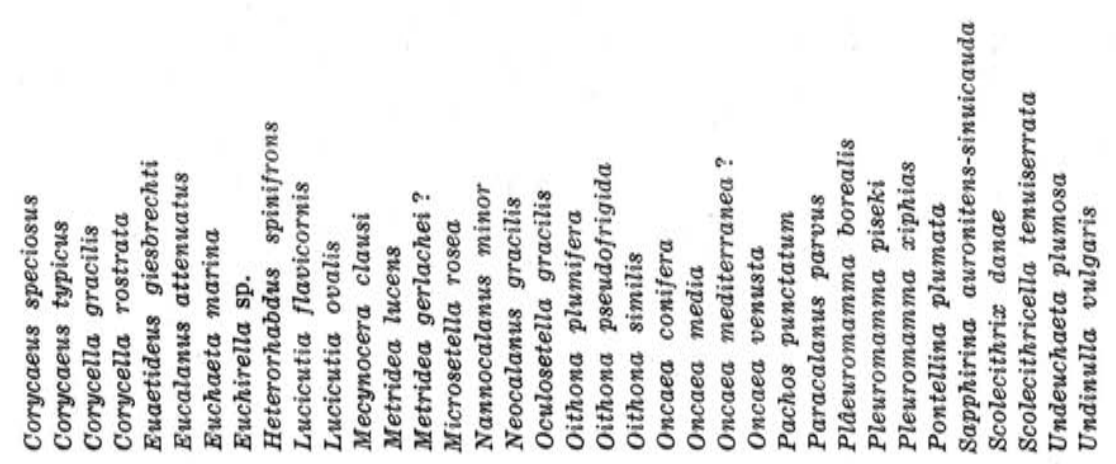


1960 , p. 180). They are rich waters where plankton volumes average $1.62 \mathrm{ml} / \mathrm{m}^{3}$ along the $30^{\circ}$ meridian in the Atlantic (Kanaeva 1960, p. 117). When copepod lists for these waters are compared (Tanaka 1960, p. 7-8; Farran 1929, p. 207-211; Kusmorskaya 1959 , tab. 5, p. 147) we find our data confirmed. Samples of the middle South Atlantic (Stations 5827, 5826, 5825 of the "Atlantis" cruise 247) and of waters probably belonging to the Benguela Current (Stations 5833, 5834, 5839 of the "Atlantis" cruise 247) have approximately the same species composition (Table XVI). Vervoort (1946) recorded the following species in deep cool waters sampled by the "Snellius" Expedition in the IndoPacific waters: Calanus tenuicornis, Nannocalanus minor, Neocalanus gracilis, Undinula darwini, Eucalanus mucronatus, Eucalanus subtenuis, E. crassus, Rhincalanus cornutus, Paracalanus aculeatus, Clausocalanus arcuicornis and C. furcatus. Della Croce (1959, p. 40-41) recorded approximately the same species in the subtropical waters of the Tyrrhenian and Ligurian Seas as those found here. Bainbridge (1960, tab. 1) recorded off Ghana the following species in decreasing numbers in samples collected in water layers with temperatures usually under $21.5^{\circ} \mathrm{C}$ and salinity around $35.7 \%$ (Bainbridge, in lit.) : Calanoides carinatus, Temora turbinata, T. stylifera, Paracalanus parvus, Corycaeus giesbrechti, Centropages chierchiai, Eucalanus monachus, Clausocalanus arcuicornis, Eucalanus pileatus, Paracalanus aculeatus.

\section{DEEP SUBTROPICAL WATERS}

The association of species in subtropical waters below the Brazil Current was not studied in this paper because no plankton samples from that habitat were available. The deepest samples examined were those collected near the edge of the shelf (Table XIV) as well as samples from the Brazil Current which were sampled by hauling the net from $200 \mathrm{~m}$ depth up to the surface. Copepods which appeared only in samples from stations occupied during the night in tropical water are probably the result of migration from this deeper layer. Samples M 76 and M 78 show some of the species which belong to this environment and which did not appear in the other samples.

The species which belong to this environment are probably Undeuchaeta major, Neocalanus gracilis, Ctenocalanus vanus, Euaetideus giesbrechti, Scolecithricella dentata, Centropages violaceus, Eucalanus attenuatus, Euchirella brevis, E. rostrata, Calanoides carinatus, Scaphocalanus curtus, Pleuromamma spp., Heterorhabdus spp., Haloptilus spp., Rhincalanus cornutus and $R$. nasutus, Temeropia mayumbaensis, Lophothrix latipes, Euaugaptilus hecticus. 


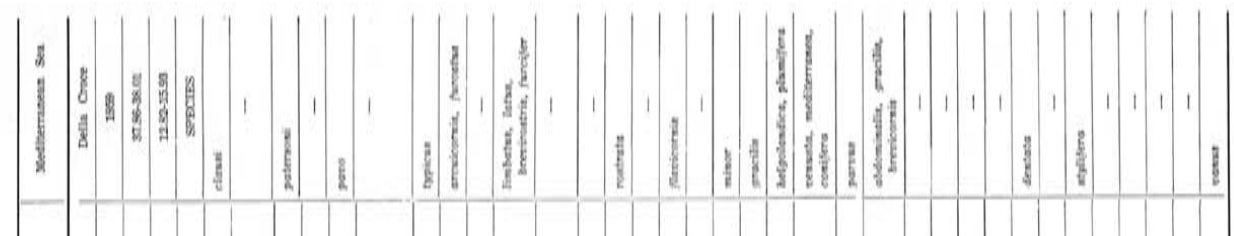

औH:M"

4.

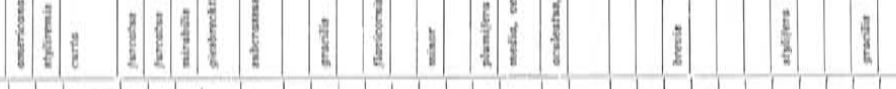

Hann

竞

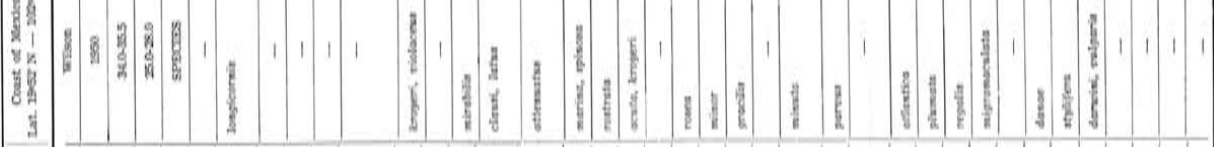

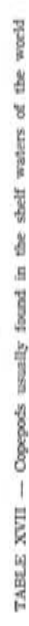

象

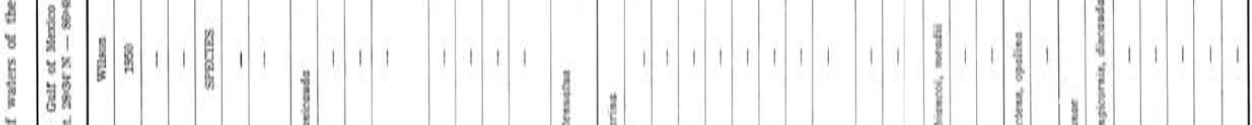

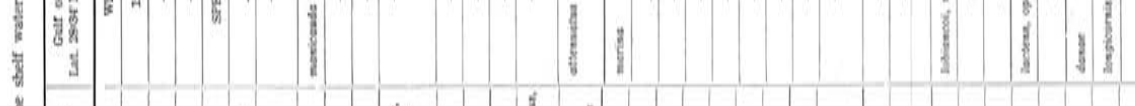

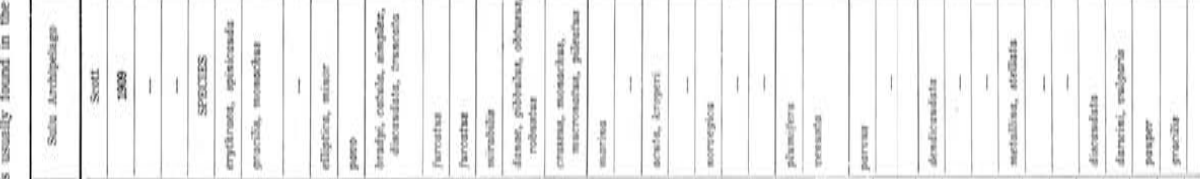

8

I 1 2 (a) Ho

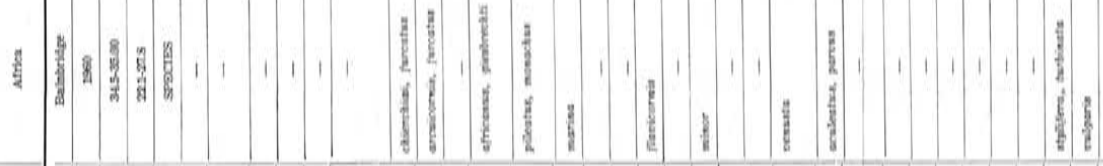

f i llill ill ill

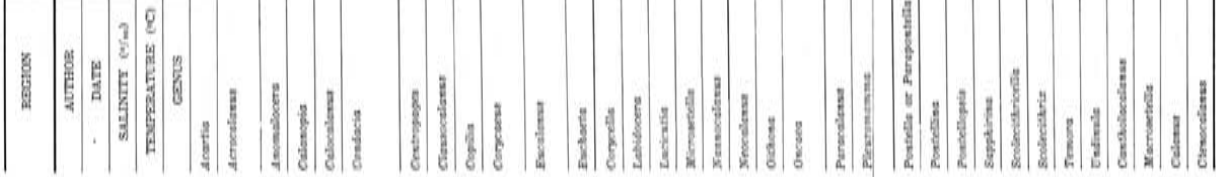




\section{O N CLUS ION S}

I - A comparison of the different graphs of the most numerous and frequent copepods show that the two fundamental habitats of copepods off the coast of Brazil are the TROPICAL WATERS (T) with the greatest number of species and the COASTAL WATERS (C), the next most numerous in species.

These two habitats mix over the shelf with others and produce several intermediate habitats like what is here called SURFACE SHELF WATER (SS), where some species do not find living conditions and die. The want of sufficient depth of layers and the higher temperature or the lower salinity may be among the causes of this change. In the South the tropical waters gradually loose heat and form another intermediate habitat - the SURFACE SUBTROPICAL (SST) water where many tropical copepods do not survive because of the lower temperature.

There are indications of the existence of another typical habitat - the DEEP SUBTROPICAL WATER. This mixes with the tropical and also with the coastal waters when it moves onto the shelf and constitutes another intermediate habitat - the DEEPER SHELF WATER (DST). In this many deep living "subtropical" copepods do not resist the want of depth or other factors and die off or diminish in frequency.

II - The most numerous and frequent species in the TROPICAL WATERS are Corycella gracilis, Nannocalanus minor, Oncaea venusta, Corycaeus speciosus, Centropages violaceus, Neocalanus gracilis, Oithona plumifera, Pleuromamma abdominalis, Undinula vulgaris, Scolecithrix danae, Lucicutia flavicornis, Euchaeta marina, Macrosetella, Calocalanus pavo and Clausocalanus furcatus. The dominant ones in volume may be Clausocalanus furcatus, Scolecithrix danae, Nannocalanus minor, Undinula vulgaris and Pleuromamma abdominalis. Usually nearly all the "tropical" water copepods can live also in the mixed waters of the surface shelf and in the surface subtropical water. Clausocalanus furcatus and Corycella gracilis are found in the same or almost same numbers in surface shelf waters. Neocalanus gracilis and Corycella gracilis are found in the surface subtropical and in the deep shelf waters.

III - COASTAL WATERS show the greatest frequency of the following copepods: Oncaea media, Oithona ovalis, Sapphirella, Acartia lilljeborghi, Euterpina, Eucalanus monachus, Eucalanus subcrassus, Paracalanus crassirostris and Pseudodiaptomus acutus. 
The species dominant in volume belong to the genera Oncaea, Eucalanus, Acartia and sometimes Oithona or Pseudodiaptomus. Some species are also found in the surface shelf water like $E$. subcrassus, E. monachus, Euterpina and Acartia lilljeborghi. These are also found in the DEEPER SHELF WATER, thus indicating the coastal water influence in this environment. $P$. crassirostris and $O$. ovalis are found in the deeper shelf water also.

The surface subtropical waters appear to be a bad environment for nearly all coastal copepods. Oncaea media is the only species which is also found in the surface subtropical habitat. Pseudodiaptomus acutus has its optimum in the inshore waters where salinities are low.

Centropages furcatus, Calanopia americana, Temora stylifera and Paracalanus aculeatus have their optimum in the SURFACE SHELF WATERS but generally may be found in other environments. Only Calanopia americana shows a distinct preference for coastal waters and is not found in the tropical nor in the subtropical waters, but in all the mixed waters which may suffer the influence from the coastal waters.

IV - The SURFACE SUBTROPICAL WATERS show a greater frequency of Clausocalanus arcuicornis, Corycaeus ovalis, Mecynocera clausi, Acartia danae, Candacia aethiopica, Corycella rostrata, Oithona setigera, besides the already mentioned tropical water copepods. The above species of the surface subtropical waters excepting Corycella rostrata and Candacia aethiopica are usually found in all the other environments, but with less or no frequency at all in the coastal, which is the most different environment from that in which they have their optimum.

Corycella rostrata and Candacia aethiopica are also found in tropical waters. The first is frequent in deep subtropical waters also.

Calanus tenuicornis, though more frequent in surface subtropical, apparently has its maximum number in the DEEPER SHELF WATERS. These are also preferred by the following copepods: $\mathrm{Ca}$ lanoides carinatus, Ctenocalanus vanus, Clytemnestra sp., Corycaeus amazonicus, Paracalanus parvus, Oithona nana. All these copepods usually appear also in the coastal and surface shelf waters, specially in lower temperatures. Clytemnestra sp., Corycaeus giesbrechti are also frequent in the tropical waters and less frequent in the cooler waters (surface subtropical). 
Calanoides carinatus, Calanus tenuicornis, Ctenocalanus vanus are copepods found in cooler waters and therefore usually less frequent or absent in tropical waters and warm shelf and coastal waters. They may be the dominant copepods in volume in cooler waters off Brazil.

$\mathrm{V}$ - Besides these frequent copepods there are several species which appear only in one environment and are therefore characteristic of it. Many copepods were only registered in tropical waters, others only in deep waters, but in too small numbers to be useful as ecological indicator species.

VI - Although some species occur off the Brazilian coast in very saline or in deeper waters, they seem to prefer other environments in other regions, thus strongly suggesting the existence of different races within the same species or at least a great adaptational capacity. Ctenocalanus vanus is an example of this.

VII - Many copepods are usually very conservative as to certain parameters of their surroundings like Eucalanus subcrassus and Paracalanus crassirostris. The first prefers medium salinities all over the world and the second prefers coastal waters also all over the world.

VIII - Usually copepods from high salinities and high temperatures may occur in low salinities and low temperatures, but rarely (as Corycaeus) in high salinities and low temperatures.

IX - When only Brazilian waters are studied wrong conclusions may be taken, for instance, that certain copepods are more stenohaline than stenothermic. When our lists of species are compared to those of the Pacific, the conclusion is that copepods tend to be stenothermic and usually strongly euryhaline.

Tables VI, X and XVII contain very few data from the Pacific Ocean. There are differences between the lists of species of the Pacific, especially of the North East Pacific and those of the Atlantic of waters of approximately the same temperatures, because the salinities of the Pacific waters are generally lower than those of the Atlantic (Sverdrup et al., 1942, p. 721). Thus the species lists published by Wilson $(1950$, p. 352-432) and by Scott (1909, p. 278-313) for a number of stations in the oceanic waters of the North Pacific and in the Indo-Pacific usually show: $1-$ a greater richness in the number of species per genus found in 
each station when compared to our lists, 2 - the presence of species which here are characteristic of shelf waters (waters of lower salinities, around $35.00 \%$ ) like Eucalanus subcrassus, 3 - the presence of copepods which only occur here in waters of high salinities, and 4 - the presence of copepods of very saline warm waters that survive in lower salinities and lower temperatures.

Thus, Haloptilus and Heterorhabdus, Pontellina plumata, Rhincalanus are listed in waters of salinities known to be between 33.00 and $35.00 \%$ (for instance, off Ecuador) in temperatures around $27^{\circ} \mathrm{C}$ (therefore comparable in temperature to our tropical waters). These species which are never found in low salinities in pure coastal waters off the Brazilian coast probably are stenoecious, rather than stenohaline. They are usually found in waters overlaying big depths. Calanopia is found in the Pacific stations inside gulfs or near islands (Wilson 1950, p. 352-432; Scott 1909, p. 278-373) where there is influence probably of shallower water. It is therefore a good indicator of shelf and coastal water.

$\mathrm{X}$ - Some copepods are good geographical indicators, thus some coastal and inshore species endemic in the Brazilian waters have not yet been recorded in any of the other waters of the world. Oithona ovalis Herbst, Acartia giesbrechti Dahl, Pseudodiaptomus acutus and $P$. richardi Dahl seem to be good examples of this.

XI - Zoogeographically the waters off the southern coast of Brazil (State of Rio Grande do Sul) may be termed as a "Mischgebiet" (Steuer 1928, p. 217-218) a zone where the cold southern water current (Falkland Current) meets the warm originally tropical water and where several intermediate habitats with their characteristic faunae are found together.

XII - There is usually a dominance of copepods in the open sea plankton (Hentschel 1933, p. 96). Thus the dominant species determined for the copepods present in a sample is possibly dominant for the whole community to which it belongs in that environment.

XIII - The three schematic profiles (Figs. 49, 50, 51 and map 1) along parallels $23^{\circ}, 25^{\circ}$ and $35^{\circ} \mathrm{S}$ represent the usual associations of frequencies of species found in the different environments off the southern Brazilian coast and summarizes the results. 


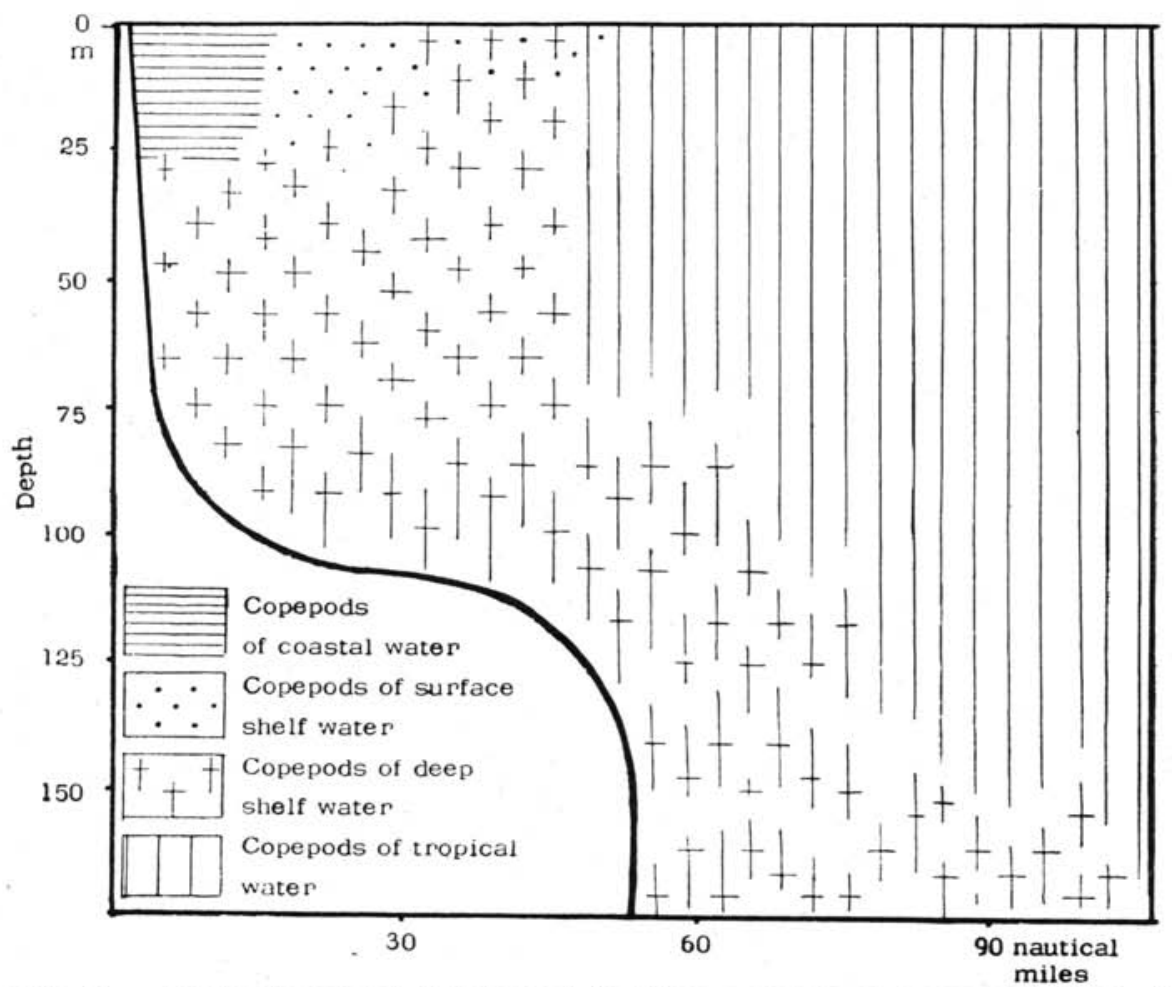

Fig. 49 - Different copepod associations found in a profile along parallel $23^{\circ} \mathrm{S}$ off Brazil (schematic representation). Notice the deep water reaching the surface.

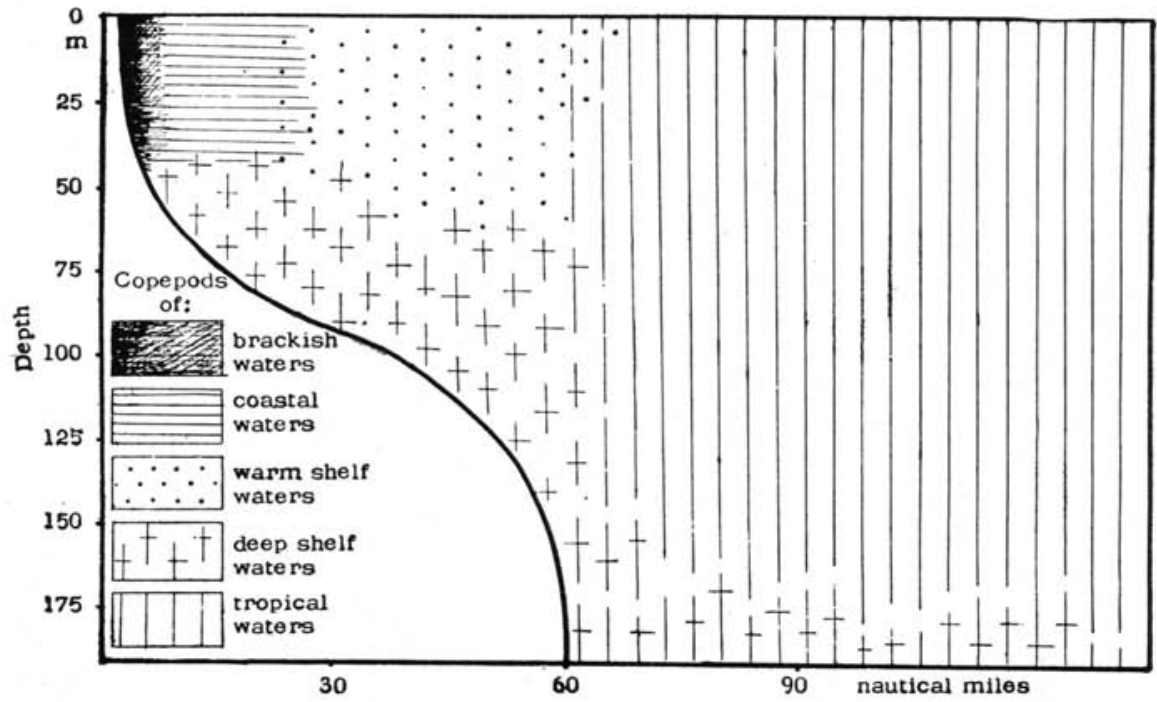

Fig. 50 - Different copepod associations found in a profile along $25^{\circ} \mathrm{S}$ off Brazil (schematic representation). 

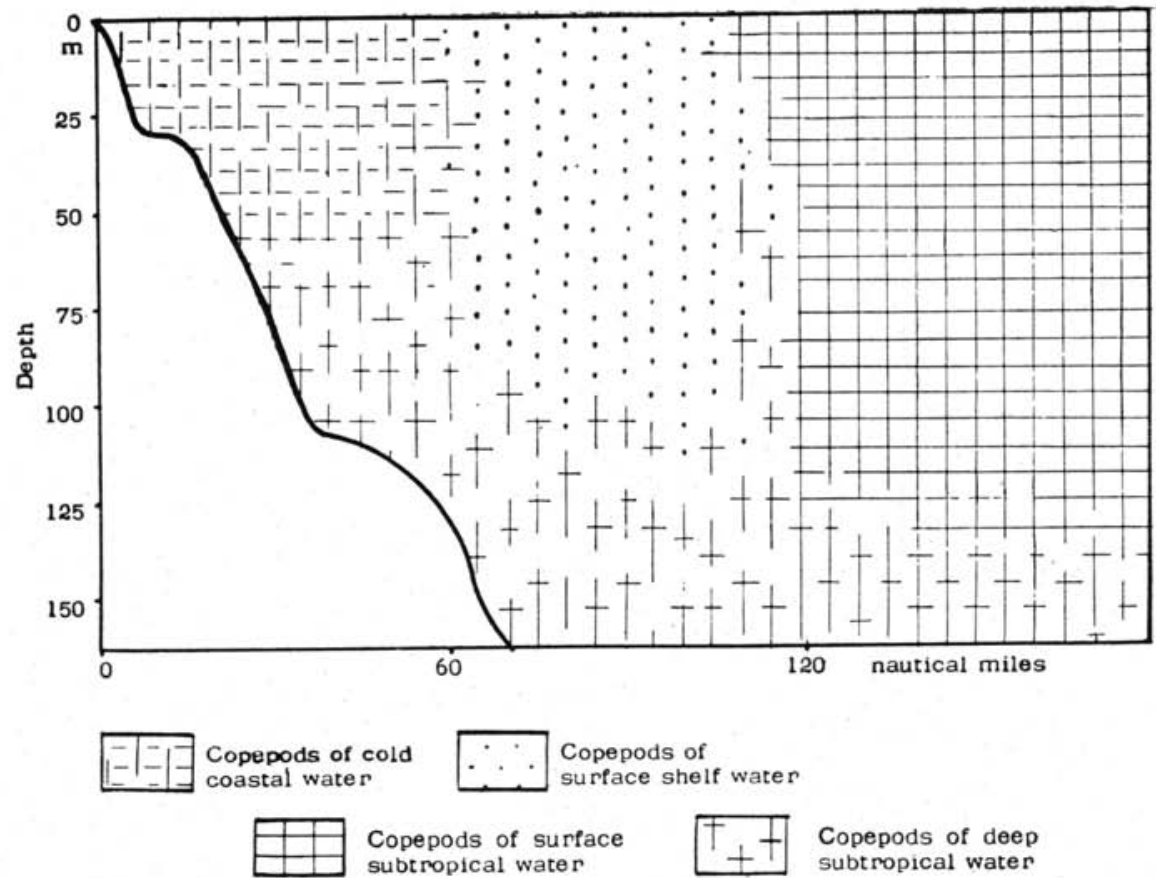

Fig. 51 - Diagram showing the associations present off Rio Grande do Sul. Notice absence of the typical tropical associations of species and the presence of cold coastal water fauna.

\section{S U M A R I O}

Poucos autores dedicaram-se ao estudo de copépodos da região tropical e subtropical do Atlântico Sul ocidental. Alguns autores estudaram águas costeiras e salobras. As águas do alto mar e da plataforma continental foram estudadas pouco ou nada, sob o ponto de vista dos copépodos, pelas grandes expedições.

O presente trabalho é um estudo comparativo da fauna de copépodos nestas diferentes águas, tendo distinguido os seguintes habitats: água tropical, água subtropical de superfície, água de plataforma quente superficial, água de plataforma fria de profundidade e águas costeiras.

Estudou-se ainda alguns parâmetros característicos do ambiente em que vive cada uma das espécies de copépodos assinalada em nossas águas e procurou-se analisar as aparentes discrepâncias na ocorrência destas espécies em outros ambientes, assim como a homogeneidade das associações características das regiōes tropical, subtropical, costeira e de plataforma em todos os oceanos do mundo. Algumas características morfológicas de certas espécies foram assinaladas e a variedade nova "cryophyla" de Acartia tonsa descrita. 


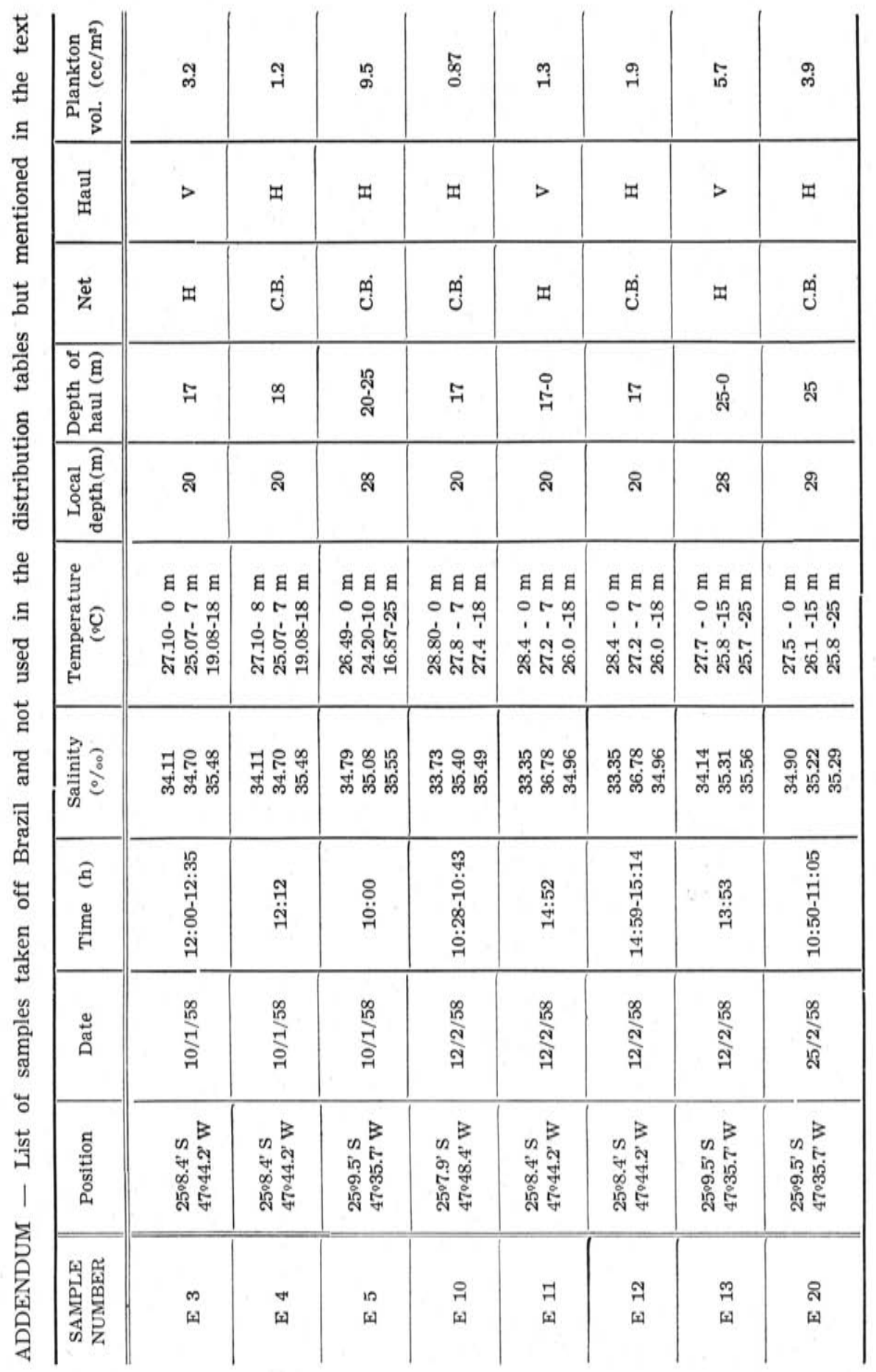




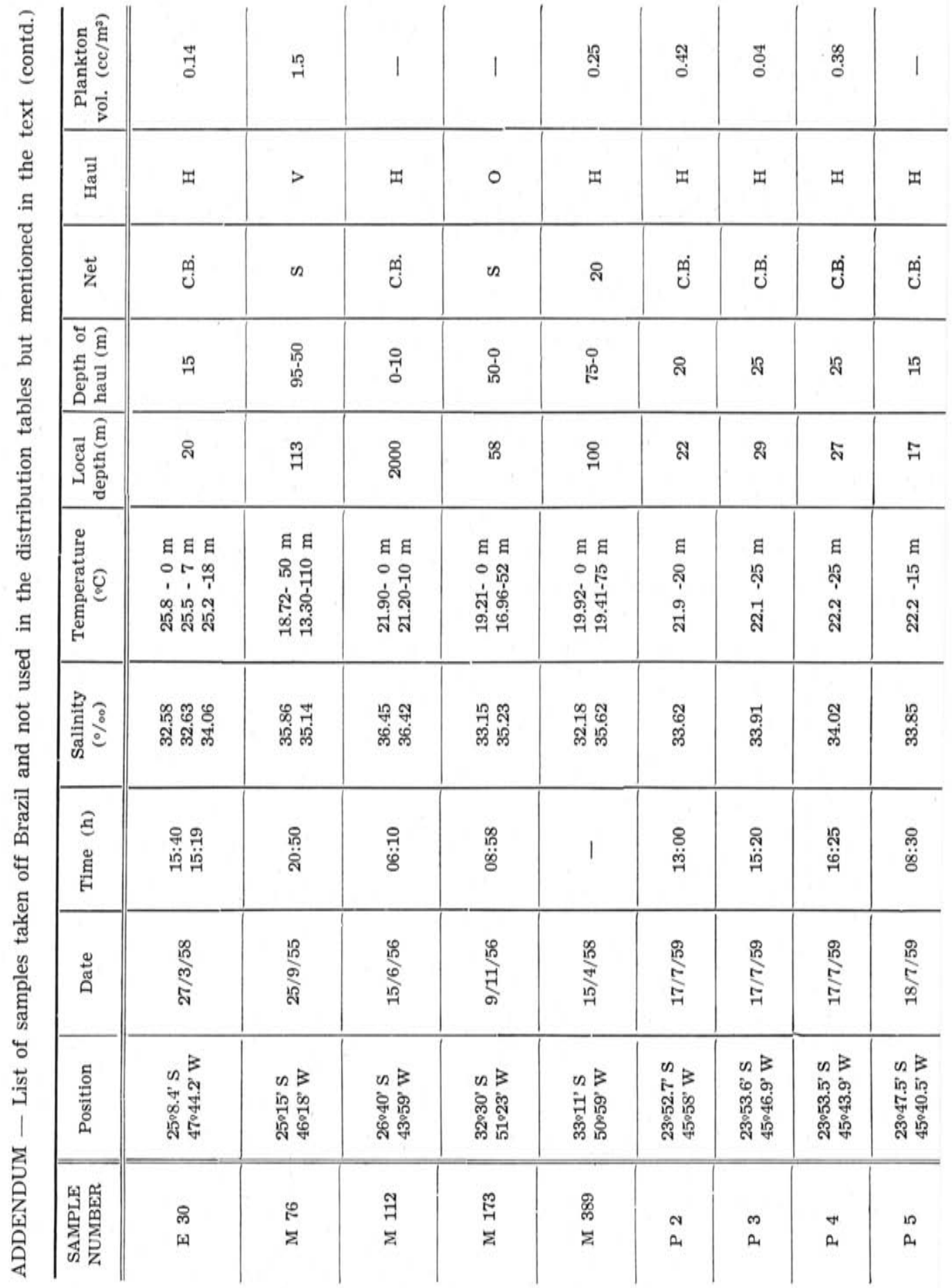




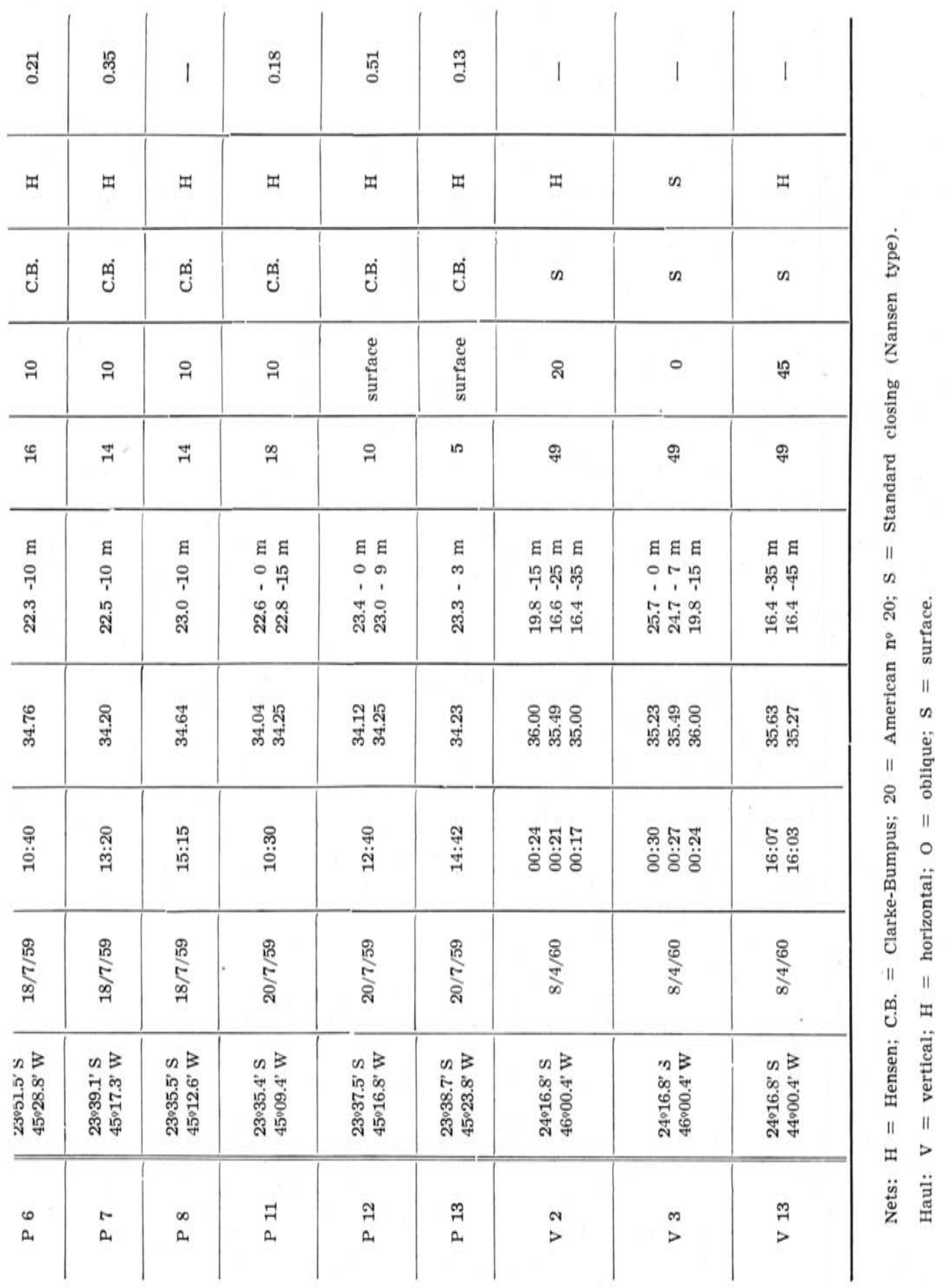




\section{ACKNOWLEDGEMENTS}

Dr. Vannucci, Dr. Forneris, Miss Almeida Prado and Mr. Teixeira made helpful suggestions. Dr. Emilsson gave good advice concerning the hydrographic part of the work. Miss Alves Costa, Mr. Silva Telles, Mr. del Rio Garcia helped in the calculations, the preparation of the sample lists, the revision of the text, and drawing of the graphs. Mr. Lucki helped in the translation of the Russian texts consulted.

\section{REFER ENCES}

Almeida Prado, M. S.

1961. Distribuição dos Chaetognatha no Atlântico Sul Ocidental. Bol. Inst. Ocean., vol. 11, n. $^{\circ} 4$, p. 15-49.

1962. Sôbre o plâncton da enseada do Mar Virado e os métodos de coletas. Bol. Inst. Ocean., vol. 12, n. $^{\circ} 3$, p. 49-68.

BAINBRIDGE, V.

1960. Occurrence of Calanoides carinatus (Kröyer) in the plankton of the Gulf of Guinea. Nature, vol. 188, n. ${ }^{\circ} 4754$, p. 932-933.

BJöRNBERG, T. K. S.

1959. Copepods as indicators of water masses off the Brazilian coast. In Sears, M., ed. - Intern. Ocean. Congr., I, Preprints, p. 137-138. Washington, Amer. Assoc. Adv. Sci., 1022 p.

BJöRNBERG, T. K. S. \& ForNeris, L.

1956a. On the uneven distribution of the Copelata of the Fernando de Noronha area. Bol. Inst. Ocean., vol. 7, n. ${ }^{\circ} 1 / 2$, p. 105-111.

1956b. On the uneven distribution of the Copelata of the Alcatrazes area. Bol. Inst. Ocean., vol. 7, n. ${ }^{\circ}$ 1/2, p. 113-115.

Bogorov, B. G.

1958. Biogeographical regions of the plankton of the northwestern Pacific Ocean and their influence on the deep sea. Deep-Sea Res., vol. 5 , n. ${ }^{\circ}$, p. $149-161$.

Brady, G. S.

1883. Report on the Copepoda collected by H.M.S. "Challenger" during the years 1873-76. Rep. Sci. Res. Challenger, part 23, Zool. 8, p. 1-142, pls. 55 .

BREemen, P. J.

1906. Marienne copepoden. I Fauna van Nederland. Boekhandel en Drukery, E. J. Brill, p. 1-31.

Brodsky, K. A.

1950. Calanoida copepods of the far-eastern seas of the URSS and polar basin. Anal. tabl. of the Fauna USSR. Publ. Zool. Inst. Akad. Nauk. USSR, n. ${ }^{\circ} 35,445$ p. 306 figs. (In Russian).

1957. Copepod fauna (Calanoida) and their zoogeographical zonation in the West Pacific Ocean and nearby waters. Zool. Inst. Akad. Nauk. USSR, 222 p., 34 text-figs. (In Russian). 
1959. Zoogeographical zones of the South Pacific and bipolar distribution of some calanoids. In Sears, M., ed. - Intern. Ocean Congr., I, Preprints, p. 145-147. Washington, Amer. Assoc. Adv. Sci., 1022 p.

BRUNS, E.

1958. Ozeanologie. Bd. I. Berlin, Veb. Deuts. Verlag Wissensch., 420 p. 145 figs. 7 maps.

*Burkov, V. A.

1960. The studies of the equatorial currents of the Pacific Ocean. $\mathrm{X}$ Section of the IGY Program (Oceanology). Ocean. Res., n. ${ }^{\circ}$ 2, p. 117-126. (In Russian).

Candeias, A.

1930. Estudos de plancton na Baía de Sezimbra. Trav. Sta. Biol. Mar. de Lisbonne, n. ${ }^{\circ} 23$, p. 1-72, 6 ests.

Carvalho, J. de P.

1939. Variação do plancton na baía de Santos (Nota prévia). Bol. Biol., n.s., vol. 4, n. $^{\circ} 1$, p. $32-49,19$ figs.

1944. Copépodos de Caiobá e baía de Guaratuba. Arq. Mus. Paranaense, vol. 4, p. 83-116 (1945).

1952. Sôbre uma coleção de copépodos, não parasíticos, da baía de Santos e suas adjacências. Bol. Inst. Ocean., vol. 3, n. $^{\circ} 1 / 2$, p. 131-183.

Colebrook, J. M., Brown, W. W. \& John, D. E.

1961. Copepoda. Part II. Contributions towards a Plankton Atlas of the North Eastern Atlantic and the North Sea. Bull. Mar. Ecol., vol. 5, n. ${ }^{\circ} 42$, p. $90-97$, pls. 21-27.

*Comité Central d'Oceanographie et d'Étude des Cotes, Paris.

1959. Resultats d'observations hydrologiques. 2. Observations du "Pyrrhus". Cahiers Ocean., vol. 11, n. ${ }^{\circ} 1$, p. 63-70.

CONOVER, R. J.

1956. Oceanography of Long Island Sound, 1952-1954. VI. Biology of Acartia clausi and A. tonsa. Bull. Bingham Oceanogr. Coll., vol. 15 , p. $156-233$.

DAHL, F.

1892. Die Gattung Copilia (Sapphirinella). Zool. Jahrb. Abt. Syst. Geogr. Biol., Bd. 6, p. 499-522, map 24.

1894. Copepoden des unteren Amazonas. Ber. Nat. Ges. (Zool.) Bd. 8, p. 1-14.

DAHL, M.

1912. Die Corycaeinen. Ergebn. Plankton-Exped. Humboldt Stiftung, Bd. 26, f. 1, p. 1-132, 16 taf.

DAVIS, C. C.

1950. Observations of plankton taken in marine waters of Florida in 1947 and 1948. Contr. n. ${ }^{\circ}$ 100, Mar. Lab. Univ. Miami. Quart. Jour. Fla. Acad. Sci., vol. 12, n. $^{\circ}$ 2, p. 67-103.

DeEvey, G. B.

1952a. Hydrographic and biological studies of Block Island Sound, 1943-46. Bull. Bingham Oceanogr. Coll., vol. 13, art. 3, p. 65-119. 
1952b. Quantity and composition of the zooplankton of Block Island Sound, 1949. Bull. Bingham Oceanogr. Coll., vol. 13, art. 3, p. $120-164$.

1956. Oceanography of Long Island Sound, 1952-1954. V. Zooplankton. Bull. Bingham Oceanogr. Coll., vol. 15, p. 113-155.

1960. The zooplankton of the surface waters of the Delaware Bay region. Bull. Bingham Oceanogr. Coll., vol. 17, art. 2, p. 5-53.

Della Croce, N.

1959. Copepodi pelagici raccolti relle crocieri talassografiche del "Robusto" nel Mar Ligure ed Alto Tirreno. Boll. Mus. Ist. Biol. Univ. Genova, vol. 29, n. ${ }^{\circ} 176$, p. 29-114.

* Discovery RePorts.

1942. Discovery investigations station list 1933-1935. Discovery Reports, vol. 22, p. 1-192, 4 pls.

Devasundaram, M. P. \& Roy, J. C.

1954. A preliminary study of the plankton of the Chilka Lake for the years 1950 \& 1951. Symposium on Marine and Freshwater Plankton in the Indo-Pacific. Bangkok, UNESCO, p. 48-54.

Dutta, N., Malhotra, J. C. \& Bose, B. 13.

1954. Hydrology and seasonal fluctuations of the plankton in the Hooghly Estuary. Symposium on Marine and Fresh-water Plankton in the Indo-Pacific. Bangkok, UNESCO, p. 35-47.

EMILSSON, I.

1959. Alguns aspectos físicos e químicos das águas marinhas brasileiras. Ciência e Cult., vol. 11, n. $^{\circ} 2$, p. $44-54$.

1961. The shelf and coastal waters off Southern Brazil. Bol. Inst. Ocean., vol. 11, n. ${ }^{\circ}$ 2, p. 101-112.

ESTERLy, C. O.

1928. The periodic occurrence of Copepoda in the marine plankton of two successive years at La Jolla, California. Bull. Scripps Inst. Oceanogr., Tech. S'eries, vol. 1, n. $^{\circ} 14$, p. 247-345.

Evans, F.

1961. The planktonic Crustacea of the "Petula" transatlantic expedition. Proc. Linn. Soc. London, vol. 172, pt. 2, p. 189-207, 2 figs. 3 tabs. Session 1959-60.

FARRAN, G. P.

1926. Biscayan plankton Copepoda. Jour. Linn. Soc. London, vol. 36 , p. 219-310, pls. 5-10, 2 tabs.

1929. Crustacea. Part X, Copepoda. British Antarctic ("Terra Nova") Expedition, 1910. Nat. Hist. Rep. Zool., vol. 8, n. ${ }^{\circ} 3$, p. 203-306.

1936. Copepoda. Great Barrier Reef Expedition, 1928-29. Sci. Rep., vol. 5 , n. ${ }^{\circ}$, p. $11-141,30$ figs.

1949. The seasonal and vertical distribution of the Copepoda. Great Barrier Reef Expedition, 1928-29. Sci. Rep., vol. 2, n. ${ }^{\circ} 9$, p. 291-311.

FLeminger, A.

1959. Distribution of Calanoid Copepods in the Gulf of Mexico. In Sears, M., ed. - Intern. Ocean. Congr., I, Preprints, p. 153154. Washington, Amer. Assoc. Adv. Sci., 1022 p. 
FLEURY, J.

1950. Répartition des copépodes recueillis au cours des pêches planctoniques de surface effectuées à bord du "Président Théodore Tissier" (Juillet 1946). Ann. Biol., Cons. Perm. Intern. Expl. Mer, 1949, vol. 6, p. 47-49, 2 figs.

Furuhashi, K.

1961. On the possible segregation found in the copepod fauna in the deep waters off the South-eastern coast of Japan (JEDS-3). Publ. Seto Mar. Biol. Lab., vol. 9, n. 1 , p. 1-16.

Giesbrecht, W.

1892. Systematik und faunistik der Pelagischen Copepoden. Fauna und Flora des Golfes von Neapel, Mon. 19, 831 p. 54 taf.

GRICE, G. D.

1962. Calanoid copepods from equatorial waters of the Pacific Ocean.

U.S. Fish Wildl. Serv., Fish Bull., vol. 61, n. ${ }^{\circ} 186$, p. 171-246.

Grice, G. D. \& Hart, A. D.

1961. Preliminary report on the analyses of zooplankton collected on four cruises between New York and Bermuda. (Unpublished manuscript).

GURNEY, R.

1927. Copepoda and Cladocera of the plankton. Cambridge Expedition to the Suez Canal 1924. Trans. Zool. Soc. London, vol. 22 , p. $139-172$, text-figs. $15-28$.

HEINRICH, A. K.

1960. Horizontal distribution of copepods in the Central Pacific and the determinant factors. Akad. Nauk. USSR. Trudy Inst. Okeanologie, vol. 41, p. 31-41, 5 text-figs. (In Russian).

1961. On the vertical distribution and diurnal migration of the copepods to the SE of Japan. Akad. Nauk. USSR. Trudy Inst. Okeanologie, vol. 51, p. $82-102,7$ text-figs. 5 tabs. (In Russian).

HENSEN, H.

1911. Das Leben im Ozean nach Zählungen seiner Bewohner. Uebersicht. u. Resultate der quantitativen Untersuchungen. Ergebn. der Plankton Expedit. Humboldt Stiftung, Bd. 5-0, v+406 p., 77 text-figs., 28 tabs., 1 taf.

Hentschel, E.

1933. Allgemeine Biologie des Südatlantischen Ozeans. Wiss. Ergebn.

Deut. Atlant. Exped. "Meteor", 1925-1927, Bd. II (1), p. 168.

HERBST, H. V.

1955. Cyclopoida gnathostoma (Crustacea Copepoda) von der brasilianische Atlantikküste. Kieler Meeresforsch., Bd. 11, n. ${ }^{\circ} 2$, p. 214-229, 9 pls.

JAKOBI, H.

1953. Sôbre a distribuição da salinidade e do $\mathrm{pH}$ na baía de Guaratuba. Arq. Mus. Paranaense, vol. 10, $1^{*}$ parte, p. 3-35. 
1954a. Harpacticoida (Cop. Crustac.) da microfauna do substrato arenolodoso do Mar de Dentro (Ilha do Mel, Baía de Paranaguá, Brasil). Dusenia, vol. 5, n. ${ }^{\circ} 5 / 6$, p. 1-232.

1954b. Espécies novas de Harpacticoida (Copepoda-Crustacea) encontradas em algas marinhas do litoral Paraná-Santa Catarina. Bol. Inst. Ocean., vol. 5, n. $.^{\circ} 1 / 2$, p. 189-212.

1955. O gênero Enhydrosoma do manguesal da costa São PauloParaná (Harpacticoida-Crustacea). Dusenia, vol. 6, n. $.^{\circ} 3 / 4$, p. 89-96.

1956. Novas espécies de Harpacticoidea (Copepoda-Crustacea) provenientes de regiões salobras da costa São Paulo-Paraná. Dusenia, vol. 7, n. $^{\circ}$, p. 159-161.

1959. Contribuição para a ecologia dos Harpacticoidea (CopepodaCrustacea). I. Rev. Bras. Biol., vol. 19, n. ${ }^{\circ} 2$, p. 133-150.

JoHNSON, M. W.

1958. Observations on inshore plankton collected during summer 1957 at Point Barrow, Alaska. Jour. Mar. Res., vol. 17, p. 272-281.

JoHNSTON, T. H.

1937. Biological organization and station list. BANZARE (1929-31). Reports Ser. B, vol. 1, n. ${ }^{\circ}$ 1, p. 1-48. (Information extracted and sent to the author by the kindness of Dr. K. Sheard).

Kanaeva, L. P.

1960. The distribution of plankton along the $30^{\circ} \mathrm{W}$ meridian in the Atlantic, April-May 1959. Soviet Fish. Inv. in North European Seas, p. 173-183, 5 figs. (In Russian).

KLEVENHUSEN, W.

1933. Die Bewölkerung des Südatlantischen Ozeans mit Corycaeen. Wiss. Ergebn. Deuts. Atlant. Exped. "Meteor", 1925-1927, Bd. 12, p. 110.

KUSMORSKAYA, A. P,

1959. Distribution of the plankton in the North Atlantic in Spring and Autumn 1958. Council Meeting 1959, Plankton Committee, n. ${ }^{\circ} 14,12 \mathrm{p}$.

1960. Zooplankton of the frontal zone in the North Atlantic in the Spring of 1958. Soviet Fish. Inv. in North European Seas, p. 139-153, 6 text-figs. 8 tabs. (In Russian).

LEHNHOFER, $\mathrm{K}$.

1926. Copepoda 2: Copilia Dana 1849. Wiss. Ergebn. Deutsch. TiefSee Exped. "Valdivia", Bd. 23, Heft 3, p. 115-117.

1929. Copepoda 5: Sapphirina J. V. Thompson 1829, Systematik u. Verbreitung der Gattung. Wiss. Ergebn. Deutsch. Tief-See Exped. "Valdivia", Bd. 22, Heft 5, p. 270-345.

MacFadyan, M. A.

1957. Animal ecology: aims and methods. London, Pitman, xx+ 264 p.

Marques, E.

1953. Copépodes marinhos de Angola. Trab. Miss. Biol. Mar., n. ${ }^{\circ} 5$. An. Junta Inv. Ultramar, vol. VIII, t. II, f. II, p. 87-126. 
1957. Copépodes dos mares de Angola. II. Ciclopoida e Harpacticoida. Trab. Miss. Biol. Mar., n. ${ }^{\circ}$ 20. An. Junta Inv. Ultramar, vol. XII, t. II, p. $133-150,5$ ests.

1958. Copépodes marinhos de Angola. (2" Campanha 1952/53). Trab. Miss. Biol. Mar., n. ${ }^{\circ}$ 24. Mem. Junta Inv. Ultramar, 4, p. 199-222, 3 ests.

*Metcalf, W. G.

1959. Oceanographic data from the Caribbean Sea "Crawford" cruise 17, February-March 1958 for the International Geophysical Year of 1957-58. Woods Hole Oceanogr. Inst., Ref. 59-9, 91 p.

*Miller, A. R.

1959. Oceanographic data from "Atlantis" cruise 247, January-June, 1959 for the International Geophysical Year of 1957-58. Woods Hole Oceanogr. Inst., Ref. n. ${ }^{\circ}$ 60-40.

MOORE, H. B.

1949. The zooplankton of the upper waters of the Bermuda area in the North Atlantic. Bull. Bingham Oceanogr. Coll., vol. 12 , art. 2, p. 1-97.

1958. Marine ecology. New York, John Wiley, xi+493 p.

Oliveira, P. H. L. de

1945. Contribuição ao conhecimento dos crustáceos do Rio de Janeiro. Ordem Eucopepoda. Mem. Inst. Oswaldo Cruz, vol. 42, n. $^{\circ} 2$, p. $449-472$.

1947. Estudos sôbre o microplancton capturado durante a viagem do navio hidrográfico "Lahmeyer" nas baías de Ilha Grande e Sepetiba. Mem. Inst. Oswaldo Cruz, vol. 44, n. ${ }^{\circ} 3$, p. 441488.

OSTENFELD, C. H.

1931. Concluding remarks on the plankton collected on the Quarterly Cruises in the years 1902 to 1908. Bull. trimestr., Cons. Perm. Intern. Expl. Mer, 4e. partie, p. 601-672.

Pesta, O.

1912. Copepoden aus dem Golf von Persien. Wiss. Ergebn. Exped. nach Mesopotamien. Crustaceen I. Ann. K.K. Naturh. Hofmuseums, vol. 26 , p. 39-62.

PIERCE, E. L.

1953. The Chaetognatha over the continental shelf of North Carolina with attention to their relation to the hydrography of the area. Jour. Mar. Res., vol. 12, n. ${ }^{\circ} 1$, p. 79-92.

REMANe, A.

1958. Ökologie des Brackwassers (p. 1-216) in "Die Biologie des Brackwassers I Theil" by Remane, A. \& Schlieper, C., in "Die Binnengewässer von A. Thienemann", Bd. 22, 348 p.

${ }^{*}$ RILEY, G. A.

1956. Oceanography of Long Island Sound, 1952-1954. II. Physical oceanography. Bull. Bingham Oceanogr. Coll., vol. 15, p. 15-46.

Rose, M.

1933. Copépodes pélagiques. Paris, Lechevalier, 374 p. (Faune de France, vol. 26). 
ROSENDORN, I.

1917. Copepoda 1: Die Gattung Oithona. Wiss. Ergebn. Deutsch. Tief-See Exped. "Valdivia", Bd. 23, Heft 1, p. 1-58.

RUSSELL, F. S.

1939. Hydrographical and biological conditions in the North Sea as indicated by plankton organisms. Jour. Cons., vol. 14, n. ${ }^{\circ}$ 2, p. 171-192.

Schmaus, P. H. \& LehNhofer, K.

1927. Copepoda 4: Rhincalanus Dana 1852 der Deutschen Tiefsee Expedition. Systematic u. Verbreitung der Gattung. Wiss. Ergebn. Deutsch. Tief-See Exped. "Valdivia", Bd. 23, Heft 8, p. $355-400$, text-figs, tabs. a-c.

ScotT, A.

1909. Free-swimming, littoral and semi-parasitic Copepoda. Part I. Copepoda of the Siboga Expedition. Siboga-Exp., Mon. 29a, 323 p. 69 pls.

SEWELL, R. B. S.

1928. Fauna of the Chilka Lake. Custacea Copepoda. Mem. Indian Mus., vol. 5 , n. $^{\circ} 12$, p. $771-851$, pls. $44-59$.

1948. The free-swimming planktonic Copepoda. Geographical distribution. The "John Murray" Expedition 1933-34. Sci. Rep., vol. 8, n. $^{\circ} 3,592 \mathrm{p}$.

Sharpe, R. W.

1911. On marine Copepoda and Cladocera of Woods Hole and adjacent regions. Proc. U.S. Nat. Mus., vol. 38, p. 405-436.

Steuer, A.

1928. Zur Faunistischen Charakterisierung des Südafrikanischen Mischgebietes. Int. Rev. Hydrobiol., vol. 20, p. 217-218.

1932. Copepoda 6: Pleuroniamma Giesbrecht 1898 der Deutschen Tiefsee Expedition. Wiss. Ergebn. Deuts. Tief-See Exped. "Valdivia", Bd. 24, Heft 1, p. 1-119, 196 text-figs., 17 maps.

1933. Zur planmässigen Erforschung der geographischen Verbreitung des Haliplanktons besonders der Copepoden. Zoogeographica, vol. 1, Pt. 3, p. 269-302.

1937. Die Verbreitung der Copepoden Gattungen Sapphirina, Copilia, Miracia, Pleuromumma, Rhincalanus u. Cephalophanes im Südatlantischen Ozean. Wiss. Ergebn. Deutsch. Exped. "Meteor" 1925-27, Bd. 12, n. ${ }^{\circ} 2$, p. 101-163.

SuAREZ-CAabro, J. A.

1959. Salinidad, temperatura y plancton de las aguas costeras de Isla de Pinos. Lab. Biol. Mar., Univ. Villanueva, Mon. 7, p. 7-24, 4 tabs.

SVERDRUP, H. V. et al.

1942. The oceans, their physics, chemistry and general biology. New York, Prentice-Hall, $\mathrm{x}+1087 \mathrm{p}$.

TANAKA, O.

1956. The pelagic copepods of the Izu region, middle Japan. Systematic account. II. Families Paracalanidae and Pseudocalanidae. Publ. Seto Mar. Biol. Lab., vol. 5, n. ${ }^{\circ}$ 3. p. 367-406, 17 figs. 
1960. Pelagic Copepoda. Biol. Res. Japanese Antarctic Res. Exped. 10. Special Publ. Seto Mar. Biol. Lab., p. 3-95, 4 pls.

VANNUCCI, M.

Amostras de plancton. Primeira viagem do "Almirante Saldanha". (Non published data).

1957a. On Brazilian Hydromedusae and their distribution in relation to different water masses. Bol. Inst. Ocean., vol. 8, n. $^{\circ} 1 / 2$, p. 23-100, 31 figs.

1957b. A nova sistemática e a planctonologia. Bol. Inst. Ocean., vol. 7, n. $^{\circ} 1 / 2$, p. $217-223$.

Vannucci, M. \& Almeida Prado, M. S.

1959. Sôbre as coletas de plancton da III e IV viagens do N/Oc "Almirante Saldanha". Contr. Avul. Inst. Ocean., Ocean Biol., n. ${ }^{\circ} 1,16$ p. 2 quadros.

VAN Riel, P. M., Hamaker, H. C. \& Van Eyck, L.

1950. Tables. The Snellius Exp., vol. 2, part 6, p. 1-44.

VERVOORT, W.

1946. The Copepoda of the Snellius Expedition. I. Leiden, E. J. Brill, p. 181, 10 figs. (Proefschrift).

1951. Plankton copepods from the Atlantic Sector of the Antarctic. Verh. Akad. Amst. Afd. Nat., Sect. 2, vol. 47, n. ${ }^{\circ}$ 4, 156 p., 82 figs.

1957. Copepods from the Antarctic and Subantarctic plankton samples of the BANZARE 1929-1931. Rep. Ser. B. (Zool. and Bot.), vol. 3, p. 1-160, 138 figs.

*VILELA, $\mathrm{H}$.

1953. Campanhas em Angola. Generalidades: Organização da Missão. Nota sumária dos primeiros resultados. Mapa das estações e tabelas dos vários elementos obtidos. Trab. Miss. Biol. Mar., n. ${ }^{\circ}$ 1, p. 9-87. (1955).

YAMAZI, I.

1956. Plankton investigation in inlet waters along the coast of Japan. XIX. Regional characteristics and classification of inlet waters based on the plankton communities. Publ. Seto Mar. Biol. Lab., vol. 5, n. ${ }^{\circ}$ 2, p. 157-196.

1957. Plankton investigations in inlet waters along the coast of Japan. XX. Diurnal change of plankton animals at an innermost station in Wakayama Harbour. Publ. Seto Mar. Biol. Lab., vol. 6, n. ${ }^{\circ}$ 2. p. 209-224.

1958. Preliminary check-list of plankton organisms found in Tanabe Bay and its environs. Publ. Seto Mar. Biol. Lab., vol. 7, n. ${ }^{\circ}$ 1, p. 111-163.

WHEELER, W. M.

1900. The free-swimming copepods of the Woods Hole region. U.S. Fish. Comm. Bull. for 1899, p. 157-192.

WIBORG, K. F.

1954. Investigations on zooplankton in coastal and offshore waters of western and northwestern Norway with special reference to the copepods. Fiskeridir. Skr., ser. Havundersök, vol. 11, n. ${ }^{\circ} 1$, p. 1-246, 102 figs. 
WILSON, C. B.

1932. The copepods of the Woods Hole region, Mass. U.S. Nat. Mus. Bull, n: ${ }^{\circ} 158$, p. 1-635, 41 pls.

1950. Contributions to the biology of the Philippine Archipelago and adjacent regions. Copepods gathered by the United States fisheries steamer "Albatross" from 1887 to 1909, chiefly in the Pacific Ocean. U.S. Nat. Mus. Bull. n. ${ }^{\circ} 100$, vol. 14, part 4, p. 141-441, 36 pls.

WORTHINGTON, L. V.

1958. Oceanographic data from the R.R.S. "Discovery II". International Geophysical Year. Cruises one and two, 1957. Woods Hole Oceanogr. Inst., Ref. n. ${ }^{\circ} 58-30,151$ p.

Note - The literature marked with an * was used to complete the hydrographical data of Tables IV, VI, X, XVI, XVII. 